\title{
ESTUDO PARA A UTILIZAÇÃO DE RESÍDUO DA FABRICAÇÃO DE PAPEL NA CONSTRUÇÃO RODOVIÁRIA
}

Dissertação apresentada à Escola de Engenharia de São Carlos, da Universidade de São Paulo, como parte dos requisitos para a obtenção do título de Mestre em Ciências, Programa de Pós-Graduação em Engenharia de Transportes.

Área de Concentração:

Infraestrutura de Transportes.

Orientador: Prof. Dr. Alexandre Benetti Parreira 



\section{FOLHA DE JULGAMENTO}

Candidato(a): Engenheiro WALTER SIDRONIO DA SILVA JÚNIOR.

Dissertação defendida e julgada em 09/08/2010 perante a Comissão Julgadora:

$$
\text { Alex B Parreina }
$$

APROVADO

Prof. Titular ALEXANDRE BENETTI PARREIRA - (Orientador)

(Escola de Engenharia de São Carlos/USP)

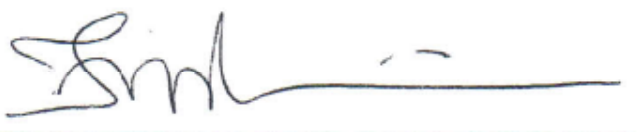

APROVADO

Prof $^{\mathrm{a}}$. Dra . ANA PAULA FURLAN

(Escola de Engenharia de São Carlos/USP)
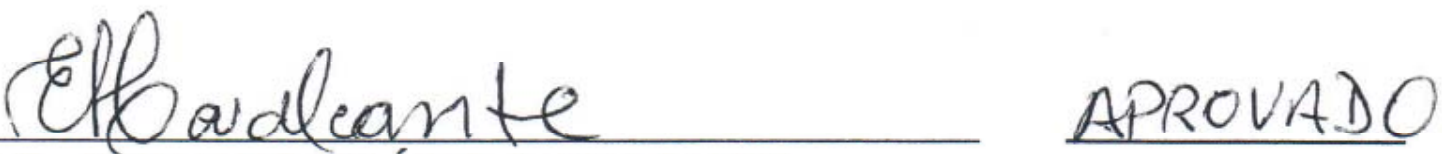

Prof. Dr. ERINALDO HILÁRIO CAVALCANTE

(Universidade Federal de Sergipe/UFS)

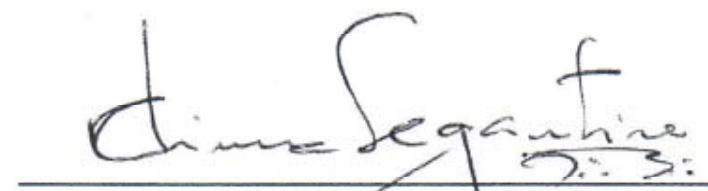

Prof. Associado PAUL LO CESAR LIMA SEGANTINE

Coordenador do Programa de Pós-Graduação em

Engenharia)de Transportes

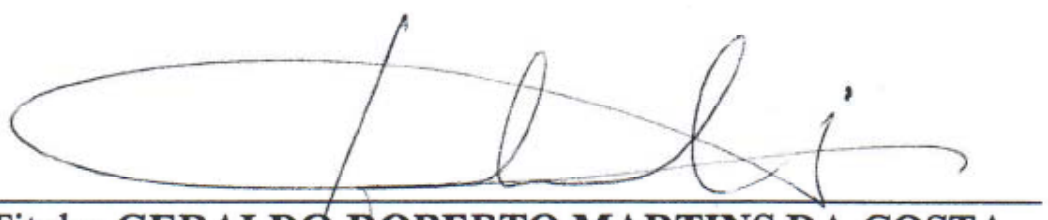

Prof. Titular GERALD $\varnothing$ ROBERTO MARTINS DA COSTA

Presidente da Cornissão da Pós-Graduação da EESC 



\section{DEDICATÓRIA}

Ao Trino Deus.

Aos meus pais, Walter e Leyd Jane.

A minha irmã, Elayne, e demais familiares.

"O Senhor é a minha força;

Torna os meus pés como os das corças,

E me faz andar sobre os lugares altos".

(Habacuque, 3:19) 



\section{AGRADECIMENTOS}

Ao Deus pai, ao filho Jesus Cristo e ao Espírito Santo sobre os quais estão todos os fundamentos humanos e sem os quais nada seria possível.

A minha família torcedora incondicional das minhas conquistas, fonte de toda a inspiração, confiança e amor, que me ampara nos momentos difíceis e me encoraja para que siga sempre em frente. Sem isso não teria chegado tão longe e com certeza hesitaria em continuar caminhando sempre. A minha irmã, Elayne, e aos meus tios, Hazziel e Adonias, por me socorrerem em diversos momentos sem hesitar.

Ao meu pastor Elí e sua esposa Zélia que me incentivaram a sair da minha cidade e prosseguir no meu sonho e num ato de confiança abriram as portas de sua casa me acolhendo como filho. Semelhante, a família da irmã Noemia que me acolhera com grande carinho em sua casa.

Aos meus professores Anísio e Maurício da graduação na UFPE, que me orientaram em todos os procedimentos necessários para a realização do curso de mestrado na USP.

Ao Exército Brasileiro por ter me liberado nos momentos necessários para que eu pudesse ter me deslocado até São Carlos e poder concluir esta dissertação.

Ao meu orientador, Prof. Dr. Alexandre Benetti Parreira, pelos conhecimentos, apoio, críticas e conselhos transmitidos no desenvolvimento dessa pesquisa, como também pela paciência para comigo, principalmente na edição final desta dissertação. 
Ao Prof. Dr. José Leomar Fernandes Júnior pelos ensinamentos, conselhos e incentivos, e também por demonstrar em diversas ocasiões atitudes de amizade e companheirismo, apesar de sua agenda cheia obtinha tempo, mesmo que por e-mails.

Ao Prof. Dr. Glauco Tulio Pessa pelo aprendizado durante o Programa de Aperfeiçoamento de Ensino (PAE) e por contribuições feitas a este trabalho.

Aos demais professores do Departamento de Transportes da EESC-USP pelos conhecimentos transmitidos.

Aos técnicos do Laboratório do Departamento de Transportes, Gigante, João e Paulo, pelos ensinamentos e ajudas nos ensaios.

Aos funcionários do departamento Heloísa, Beth, Alexandre, Magali e Antonio Carlos pela dedicação e atenção prestadas durante todo o período do mestrado.

Aos meus amigos Alex, Paulo, Francis, Wallace, Marília, Hellem, Candido, Mauro, entre outros, pelas contribuições na pesquisa e pela ótima convivência. Em especial, a dois grandes amigos, David Grubba e Sérgio Soncim, por compartilharem experiências, ensinamentos, lições de vida, discussões, momentos de críticas e de descontrações marcadas com muita alegria.

Ao ex-aluno de mestrado Weslley Ernanes Lima Novaes por ter disponibilizado diversos resultados de ensaios, dispostos nesta pesquisa, sob os quais não seria possível a realização deste trabalho.

A Coordenadoria de Aperfeiçoamento de Pessoal de Ensino Superior (CAPES) pelo incentivo financeiro prestado através da bolsa de mestrado. 
SILVA JR., W. S., Estudo para a utilização de resíduo da fabricação de papel na construção rodoviária. 210p. Dissertação (Mestrado) - Escola de Engenharia de São Carlos, Universidade de São Paulo. 2010.

A indústria de papel e celulose representa um dos mais expressivos setores industriais do mundo, sendo de grande importância para a economia mundial. Na América do Sul, devido à grande disponibilidade de recursos florestais, o Brasil e o Chile são os maiores produtores de celulose. O Brasil produz em torno de 6 milhões de toneladas de polpa por ano, dos quais $98 \%$ são branqueadas, segundo pesquisas da Unicamp (2004). A produção de papel passou por evoluções ao longo dos anos, que possibilitou o melhoramento da qualidade e velocidade de produção, fazendo com que este setor industrial gerasse um aumento na capacidade produtiva, acarretando um aumento do volume de resíduos gerados pela indústria de papel e celulose. $O$ alto consumo de papel e seus métodos de produção endossam o rol das atividades humanas mais nocivas ao planeta. Para produzir 1 tonelada de papel são necessárias 2 a 3 toneladas de madeira, uma grande quantidade de água (mais do que qualquer outra atividade industrial) e muita energia (está em quinto lugar na lista das que mais consomem energia). O principal objetivo deste trabalho é apresentar resultados da avaliação, em laboratório, de propriedades físicas e mecânicas de misturas constituídas de solo, cal e resíduo da fabricação de papel, visando sua utilização na construção rodoviária. Os ensaios de compactação foram realizados na energia equivalente ao Proctor Normal e o comportamento mecânico das misturas foi avaliado mediante os resultados obtidos dos ensaios de compressão simples, compressão diametral e triaxial cíclico. Para a realização destes ensaios escolheram-se os teores de 0 e $40 \%$ de resíduo e os teores 0,5 e $10 \%$ de cal. Avaliou-se, também, a rigidez do material mediante o módulo tangente inicial $\left(E_{0}\right)$ e módulo de resiliência $\left(M_{R}\right)$. Os corpos-de-prova foram ensaiados sem imersão e após imersão em água por 4 horas, decorridos 7 dias de cura em câmara úmida. Posteriormente, analisou-se a influência do tempo de cura para 0, 2, 7, 28 e 84 dias de permanência em câmara úmida. Para determinar a periculosidade do resíduo foram executados ensaios ambientais de lixiviação e solubilização. Os resultados mostraram que a adição do resíduo e a influência da água agiram como agentes redutores das propriedades mecânicas. Entretanto, as misturas de solo-cal e solo-resíduo-cal atendem às especificações técnicas da State of the art 5 - Lime stabilization (TRB, 1987), oferecendo uma solução viável para a utilização destas misturas na construção rodoviária. Observou-se, também, que o aumento do tempo de cura e teor de cal conduziu a valores crescentes de resistência e rigidez. Os ensaios ambientais realizados no solo, resíduo da fabricação de papel e na mistura solo-resíduo-cal foram essenciais para se obter parâmetros que permitam acompanhar o desequilíbrio que possa surgir no meio ambiente decorrente da aplicação deste resíduo em camadas de base e sub-base de pavimentos.

Palavras Chaves: Resíduo da Fabricação de Papel, Estabilização Química, Solo-cal, Solo laterítico, Comportamento Mecânico. 

SILVA JR., W. S., Study for use the wastes of the paper manufacture in the road construction. 210p. Master's thesis. - Escola de Engenharia de São Carlos, Universidade de São Paulo. 2010.

The paper and pulp industry represent one of the most expressive industrial sector around the world, being of great importance to the world economy. In South America, because of the wide forest resources, Brazil and Chile are the largest pulp-producing. Brazil produces around 6 million tons of pulp per year, among which $98 \%$ of the pulp are produced by the bleaching process, according to research from Unicamp (2004). The paper production has undergone changes through the years, which enabled the improvement of the quality and speed of production. It made that this industrial sector has an increase of productive capacity and of waste's volume produced for the paper and pulp industry. The high consumption of paper and its productions ways increase the contingent of human most harmful activities to the planet. To produce 1 ton of paper are necessary from 2 to 3 tons of wood, a lot of water (more than any other industrial activity) and a lot of energy (it is in the fifth place in the list of industries that consume more energy). The main goal of this paper is present results of assessment, in laboratory, of physical and mechanical properties of mixtures of soil, lime and residue from the manufacture of paper, for their use in road construction. The compaction tests were made in the equivalent energy to the normal Proctor and the mechanical behavior of the mixtures was evaluated on the strength of the results of tests for unconfined compressive strength, diametrical compression and cyclic loading triaxial. For these tests have been chosen the levels of 0 and $40 \%$ of waste and the levels 0,5 and $10 \%$ of lime. It was evaluated also the stiffness of the material by the initial tangent modulus (E0) and resilient modulus (MR). The samples were tested without immersion and after immersion in water for 4 hours, after 7 days of cure in a moist chamber. Subsequently, it was analyzed the influence of curing time for $0,2,7,28$ and 84 days of stay in a moist chamber. To determine the dangerousness of the residue were performed environmental testing of leaching and solubility. The results showed that the addition of waste and the influence of water acted as reducing agents of mechanical properties. However mixtures of soil-lime and soil-residuelime meet the technical specifications of the State of the art 5 - Lime stabilization (TRB, 1987), providing a feasible solution to the use of such mixtures in road construction. Observed also that increasing the curing time and content of lime led to increasing values of strength and stiffness. The environmental testing conducted in the soil residue from the manufacture of paper and the mixture soil-residue-lime were essential for obtaining parameters for monitoring the imbalance that may arise in the environment resulting from the application of this waste in layers of base and sub base's pavements.

Keywords: Waste of Paper Manufacturing, Stabilization Chemistry, Soil-Lime, Lateritic Soils, Mechanical behavior. 



\section{LISTA DE FIGURAS}

Figura 2.1 - Processo de produção da pasta de celulose

Figura 2.2 - Seções de uma máquina de papel

Figura 2.3 - Processo de recuperação química

Figura 2.4 - Composição do resíduo em porcentagem

Figura 3.1 - Lama de calcário e dregs após secagem e homogeneização

Figura 3.2 - Indicação aproximada dos locais de coleta das amostras

Figura 3.3 - Curva granulométrica do resíduo da pasta de celulose

Figura 3.4 - Curva granulométrica dos solos

Figura 3.5 - Localização dos pontos representativos dos solos

Figura 3.6 - Curva Mini-MCV x teor de umidade

Figura 3.7 - E Equipamento para moldagem dos corpos-de-prova de compressão simples:

(1) cilindro principal, (2) anéis complementares e (3) êmbolos espaçadores.

Figura 3.8 - Prensa hidráulica para moldagem

Figura 3.9 - Ruptura dos corpos-de-prova no ensaio de compressão simples

Figura 3.10 - Estimativa de $E_{0}$ a partir da determinação do coeficiente "a", segundo o modelo hiperbólico proposto por DUNCAN \& CHANG (1970).

Figura 3.11 - Equipamento para moldagem dos corpos-de-prova de compressão diametral:

(1) cilindro principal, (2) êmbolo menor e (3) êmbolo maior.

Figura 3.12 - Ruptura dos corpos-de-prova no ensaio de compressão diametral

Figura 3.13 - Prensa MTS modelo 815

Figura 3.14 - LVDT's instalados nos terços médios do corpo-de-prova

Figura 4.1 - Curvas de compactação dos solos e das misturas de solo e resíduo, sem adição de cal.

Figura 4.2 - Curvas de compactação das misturas constituídas com o solo argiloso nãolaterítico (NG').

Figura 4.3 - Curvas de compactação das misturas constituídas com o solo argiloso laterítico (LG'). 
Figura 4.4 - Curvas de compactação das misturas constituídas com o solo arenoso laterítico (LA').

Figura 4.5 - Massa específica seca máxima em função do teor de cal para as misturas com solo argiloso não-laterítico (NG'), sem resíduo e com $40 \%$ de resíduo

Figura 4.6 - Massa específica seca máxima em função do teor de cal para as misturas com solo argiloso laterítico (LG'), sem resíduo e com $40 \%$ de resíduo.

Figura 4.7 - Massa específica seca máxima em função do teor de cal para as misturas com solo argiloso não-laterítico (NG'), argiloso laterítico (LG') e arenoso laterítico (LA'), com $40 \%$ de resíduo.

Figura 4.8 - Umidade ótima em função do teor de cal para as misturas com solo argiloso não-laterítico (NG'), sem resíduo e com $40 \%$ de resíduo.

Figura 4.9 - Umidade ótima em função do teor de cal para as misturas com solo argiloso laterítico (LG'), sem resíduo e com $40 \%$ de resíduo.

Figura 4.10 - Umidade ótima em função do teor de cal para as misturas com solo argiloso não-laterítico (NG'), argiloso laterítico (LG') e arenoso laterítico (LA').

Figura 4.11 - Variação da resistência à compressão simples sem cura com o teor de resíduo para o solo argiloso não-laterítico (NG') e argiloso laterítico (LG').

Figura 4.12 - Variação da resistência à compressão simples sem cura com os teores de cal para as misturas de solos NG' e LG'.

Figura 4.13 - Variação da resistência à compressão simples sem cura com os teores de cal para as misturas de solos NG' e LG' com resíduo.

Figura 4.14 - Resistência à compressão simples aos 7 dias de cura para as misturas com o solo NG' e LG'.

Figura 4.15 - Resistência à compressão simples aos 7 dias de cura das misturas com o solo NG', LG', LA' e o resíduo.

Figura 4.16 - Variação da RCS do solo laterítico (LG') e não-laterítico (NG') com o tempo de cura para misturas com $10 \%$ de cal.

Figura 4.17 - Variação da RCS com o tempo de cura da mistura de resíduo com o solo laterítico (LG') e não-laterítico (NG') para misturas com $10 \%$ de cal.

Figura 4.18 - Variação da RCS do solo laterítico (LG') e não-laterítico (NG') com a imersão em água e teor de cal sem adição do resíduo.

Figura 4.19 - Variação da RCS do solo laterítico (LG') e não-laterítico (NG') com a imersão em água e teor de cal com adição do resíduo.

Figura 4.20 - Variação da RCS do solo LG' e NG' com a imersão em água e período de cura sem adição do resíduo.

Figura 4.21 - Variação da RCS do solo LG' e NG' com a imersão em água e período de cura com adição do resíduo. 
Figura 4.22 - Variação do $\mathrm{E}_{0}$ aos 7 dias de cura para as misturas com os solos NG' e LG'

Figura 4.23 - Resistência à compressão simples aos 7 dias de cura para as misturas com o solo NG', LG', LA' e o resíduo.

Figura 4.24 - Variação do $E_{0}$ do solo laterítico (LG') e não-laterítico (NG') com o tempo de cura para misturas com $10 \%$ de cal.

Figura 4.25 - Variação do $E_{0}$ com o tempo de cura da mistura de resíduo com o solo laterítico (LG') e não-laterítico (NG') para misturas com $10 \%$ de cal.

Figura 4.26 - Variação do $E_{0}$ do solo laterítico (LG') e não-laterítico (NG') com a imersão em água e teor de cal sem adição do resíduo.

Figura 4.27 - Variação do $E_{0}$ do solo laterítico (LG') e não-laterítico (NG') com a imersão em água e teor de cal com adição do resíduo.

Figura 4.28 - Variação do $E_{0}$ do solo LG' e NG' com a imersão em água e período de cura sem adição do resíduo.

Figura 4.29 - Variação do $E_{0}$ do solo LG' e NG' com a imersão em água e período de cura com adição do resíduo.

Figura 4.30 - Resistência à compressão diametral aos 7 dias de cura para as misturas com o solo NG' e LG'.

Figura 4.31 - Resistência à compressão diametral aos 7 dias de cura das misturas com o solo NG', LG', LA' e o resíduo.

Figura 4.32 - Variação da RCD do solo laterítico (LG') e não-laterítico (NG') com o tempo de cura para misturas com $10 \%$ de cal.

Figura 4.33 - Variação da RCD com o tempo de cura da mistura de resíduo com o solo laterítico (LG') e não-laterítico (NG') para misturas com $10 \%$ de cal.

Figura 4.34 - Variação da RCD do solo laterítico (LG') e não-laterítico (NG') com a imersão em água e teor de cal sem adição do resíduo.

Figura 4.35 - Variação da RCD do solo laterítico (LG') e não-laterítico (NG') com a imersão em água e teor de cal com adição do resíduo.

Figura 4.36 - Variação da RCD do solo LG' e NG' com a imersão em água e período de cura sem adição do resíduo.

Figura 4.37 - Variação da RCD do solo LG' e NG' com a imersão em água e período de cura com adição do resíduo.

Figura 4.38 - Representação tridimensional do modelo composto para o solo LG' com 5\% de cal.

Figura 4.39 - Representação tridimensional do modelo composto para o solo NG' com 5\% de cal.

Figura 4.40 - Representação tridimensional do modelo composto para o solo LG' com 10\% de cal. 
Figura 4.41 - Representação tridimensional do modelo composto para o solo NG' com 10\% de cal.

Figura 4.42 - Representação tridimensional do modelo composto para o solo LG' com 5\% de cal.

Figura 4.43 - Representação tridimensional do modelo composto para o solo NG' com 5\% de cal.

Figura 4.44 - Representação tridimensional do modelo composto para o solo LG' com 10\% de cal.

Figura 4.45 - Representação tridimensional do modelo composto para o solo NG' com 10\% de cal.

Figura 4.46 - Estrutura do pavimento hipotético considerada na análise do $M_{R}$.

Figura 4.47 - Variação do $M_{R}$ das misturas solo-cal, compostas pelos solos LG' e NG', com o teor de cal.

Figura 4.48 - Variação do $M_{R}$ das misturas solo-resíduo-cal, compostas pelos solos LG' e NG', com o teor de cal.

Figura 4.49 - Variação da concentração dos elementos químicos $\mathrm{Na}, \mathrm{SO}_{4}{ }^{2-}, \mathrm{Pb}, \mathrm{Cr}$ e $\mathrm{C}_{6} \mathrm{H}_{5} \mathrm{OH}$

Figura 4.50 - Variação da concentração dos elementos químicos Al e $\mathrm{F}^{-}$ 


\section{LISTA DE TABELAS}

Tabela 2.1 - Resíduos sólidos de fábricas brasileiras de pasta de celulose que utilizam o processo Kraft, 1995/1996.

Tabela 3.1 - Massa específica, LL, LP e IP dos sólidos do resíduo e dos solos

Tabela 3.2 - Classificações USCS e HRB dos solos

Tabela 3.3 - Resultados dos ensaios da metodologia MCT

Tabela 3.4 - Composição química e física da cal utilizada

Tabela 3.5 - Misturas ensaiadas para o solo argiloso laterítico (LG').

Tabela 3.6 - Misturas ensaiadas para o solo argiloso não-laterítico (NG').

Tabela 3.7 - Misturas ensaiadas para o solo arenoso laterítico (LA').

Tabela 3.8 - Seqüência de ensaio para base/sub-base segundo a AASHTO T 307-99

Tabela 4.1 - Massa específica seca máxima e umidade ótima das misturas de resíduo e solo, sem adição de cal.

Tabela 4.2 - Massa específica seca máxima e umidade ótima dos solos, das misturas de solo-cal e das misturas de solo-resíduo-cal.

Tabela 4.3 - Resistência à compressão simples sem cura das misturas solo-resíduo.

Tabela 4.4 - Resistência à compressão simples sem cura dos solos, misturas solo-cal, misturas solo-resíduo e misturas solo-resíduo-cal.

Tabela 4.5 - Resistência à compressão simples para as misturas solo-cal, solo-resíduo e solo-resíduo-cal.

Tabela 4.6 - Resistência à compressão simples das misturas de solo-resíduo-cal e solo-cal para os tempos de cura de $0,2,7,28$ e 84 dias.

Tabela 4.7 - RCS e perdas de resistência das misturas de solo-cal e solo-resíduo-cal para corpos-de-prova ensaiados com imersão em relação aos ensaiados sem imersão em água.

Tabela 4.8 - Resistência à compressão simples das misturas e a perda de RCS para corpos-de-prova ensaiados com imersão e sem imersão em água em função do tempo de cura. 
Tabela 4.9 - Módulo tangente inicial para as misturas solo-cal, solo-resíduo e solo-resíduocal.

Tabela 4.10 - Módulo tangente inicial das misturas de solo-resíduo-cal e solo-cal para os tempos de cura de $0,2,7,28$ e 84 dias.

Tabela 4.11 - E0 e perdas de rigidez das misturas de solo-cal e solo-resíduo-cal para corpos-de-prova ensaiados com imersão em relação aos ensaiados sem imersão em água.

Tabela 4.12 - Módulo tangente inicial das misturas e a perda do E0 para corpos-de-prova ensaiados com imersão e sem imersão em água em função do tempo de cura.

Tabela 4.13 - Resistência à compressão diametral para as misturas solo-cal, solo-resíduo e solo-resíduo-cal.

Tabela 4.14 - Resistência à compressão diametral das misturas de solo-resíduo-cal e solocal para os tempos de cura de $0,2,7,28$ e 84 dias.

Tabela 4.15 - RCD e perdas de resistência das misturas de solo-cal e solo-resíduo-cal para corpos-de-prova ensaiados com imersão em relação aos ensaiados sem imersão em água.

Tabela 4.16 - Resistência à compressão diametral das misturas e a perda de RCD para corpos-de-prova ensaiados com imersão e sem imersão em água em função do tempo de cura.

Tabela 4.17 - Valores dos módulos de resiliência da mistura de solo-cal com 5 e $10 \%$ de cal e ensaiada sem imersão prévia

Tabela 4.18 - Parâmetros de regressão e coeficientes de determinação para as equações $4.1,4.2,4.3$ e 4.4

Tabela 4.19 - Valores dos módulos de resiliência da mistura de solo-resíduo-cal com 5 e $10 \%$ de cal e ensaiada sem imersão prévia

Tabela 4.20 - Parâmetros de regressão e coeficientes de determinação para as equações $4.1,4.2,4.3$ e 4.4

Tabela 4.21 - Características da estrutura do pavimento hipotético.

Tabela 4.22 - Modelo e valores do módulo de resiliência calculados para os modelos das misturas estudadas.

Tabela 4.23 - Resultados do ensaio de lixiviação do solo NG', resíduo da fabricação de papel e mistura solo-resíduo-cal.

Tabela 4.24 - Resultados do ensaio de solubilização do solo NG', resíduo da fabricação de papel e mistura solo-resíduo-cal. 


\section{LISTA DE ABREVIATURAS E SIGLAS}

${ }^{\circ} \mathrm{C} \quad$ Graus Celsius

A-2-4 Cascalho e areia siltosos e argilosos

A-7-5 Solos argilosos

AASHTO American Association of State Highway and Transportation Officials

ABNT Associação Brasileira de Normas Técnicas

ASTM American Society of Testing Materials

c' Coeficiente de deformabilidade da classificação MCT

$\mathrm{CaCO}_{3} \quad$ Carbonato de Cálcio

$\mathrm{CaO} \quad$ Cal virgem

CBR California Bearing Ratio

$\mathrm{ClO}_{2} \quad$ Dióxido de cloro

$\mathrm{cm} \quad$ Centímetro

$\mathrm{CPRH}$ Companhia Pernambucana de Meio Ambiente

d' Índice da classificação MCT

DNER Departamento Nacional de Estradas de Rodagem

e’ $\quad$ Índice da classificação MCT

$\mathrm{E}_{0} \quad$ Módulo tangente inicial

EESC Escola de Engenharia de São Carlos

g Grama

HRB Highway Research Board

Ical Indústria de Calcinação Ltda. 


\begin{tabular}{|c|c|}
\hline ISC & Índice de Suporte Califórnia \\
\hline $\mathrm{Kg}$ & Quilograma \\
\hline $\mathrm{kPa}$ & Quilo pascal \\
\hline LA' $^{\prime}$ & Solo arenoso de comportamento laterítico \\
\hline LG' & Solo argiloso de comportamento laterítico \\
\hline MCT & Miniatura Compactada Tropical \\
\hline MCV & Moisture Condition Value \\
\hline $\mathrm{MH}$ & Silte elástico \\
\hline Min & Minuto \\
\hline ML & Silte de baixa compressibilidade \\
\hline $\mathrm{mm}$ & Milímetro \\
\hline $\mathrm{MPa}$ & Mega Pascal \\
\hline$M_{R}$ & Módulo de Resisiência \\
\hline MTS & Material Testing System \\
\hline $\mathrm{Na}(\mathrm{OH})_{2}$ & Hidróxido de sódio \\
\hline $\mathrm{Na}_{2} \mathrm{CO}_{3}$ & Carbonato de sódio \\
\hline $\mathrm{Na}_{2} \mathrm{~S}$ & Sulfeto de sódio \\
\hline $\mathrm{Na}_{2} \mathrm{~S}$ & Sulfeto de sódio \\
\hline $\mathrm{Na}_{2} \mathrm{SO}_{4}$ & Sulfato de sódio \\
\hline $\mathrm{NaO}_{2}$ & Óxido de sódio \\
\hline $\mathrm{NaOH}$ & Hidróxido de sódio \\
\hline NBR & Norma Brasileira Registrada \\
\hline NG' & Solo argiloso de comportamento não-laterítico \\
\hline NP & Materiais Não Plástico \\
\hline $\mathrm{Pi}$ & Índice da classificação MCT \\
\hline $\mathrm{R}^{2}$ & Coeficiente de determinação \\
\hline RCD & Resistência à Compressão Diametral \\
\hline RCS & Resistência à Compressão Simples \\
\hline
\end{tabular}




\begin{tabular}{|c|c|}
\hline SM & Areia siltosa \\
\hline TRB & Tranportation Research Board \\
\hline Unicamp & Universidade de Campinas \\
\hline USCS & Unified Soil Classification System \\
\hline USP & Universidade de São Paulo \\
\hline$\Delta \sigma$ & Desvio de tensão \\
\hline$\Delta \omega$ & Desvio de umidade \\
\hline$\varepsilon$ & Deformação \\
\hline$\varepsilon_{\mathrm{a}}$ & Deformação axial \\
\hline$\varepsilon_{r}$ & Deformação resiliente \\
\hline$v$ & Coeficiente de poisson \\
\hline$\theta$ & Tensão volumétrica ou Primeiro invariante de tensões \\
\hline$\rho_{\mathrm{d}}$ & Massa específica seca \\
\hline$\rho_{\text {dmáx }}$ & Massa específica seca máxima \\
\hline$\sigma_{\mathrm{a}}$ & Tensão axial \\
\hline$\sigma_{\mathrm{c}}$ & Tensão de contato \\
\hline$\sigma_{\mathrm{d}}$ & Tensão desvio \\
\hline$\sigma_{\mathrm{t}}$ & Resistência à tração \\
\hline$\sigma_{\mathrm{xx}}$ & Tensão principal horizontal \\
\hline$\sigma_{\mathrm{zz}}$ & Tensão principal vertical \\
\hline$\sigma_{1}$ & Tensão principal maior \\
\hline$\sigma_{3}$ & Tensão confinante \\
\hline$\tau$ & Tensão cisalhante \\
\hline$\omega$ & Teor de umidade \\
\hline$\omega_{\circ}$ & Teor de umidade ótima \\
\hline
\end{tabular}





\section{SUMÁRIO}

$\begin{array}{ll}\text { 1. INTRODUÇÃO } & 27\end{array}$

1.1. IMPORTÂNCIA DO PROBLEMA 27

$\begin{array}{ll}\text { 1.2. OBJETIVO } & 29\end{array}$

1.3. ORGANIZAÇÃO DO TRABALHO 30

2. REVISÃO BIBLIOGRÁFICA

2.1. INTRODUÇÃO 31

2.2. PRODUÇÃO DA PASTA DE CELULOSE E PAPEL 32

2.2.1. Processo Kraft ou processo do sulfato 35

2.2.2. Processo de reciclagem química 37

2.3 CARACTERIZAÇÃO DOS RESÍDUOS GERADOS NA 41

PRODUÇÃO DE CELULOSE

2.3.2. Dregs 43

2.4. UTILIZAÇÃO DE RESÍDUOS DA INDÚSTRIA DE PAPEL E 43 CELULOSE NA CONSTRUÇÃO RODOVIÁRIA

2.5. ESTABILIZAÇÃO COM CAL 46

2.5.1. Efeito da cal sobre as misturas $\quad 47$

2.5.2. Materiais calcários estabilizados com cal $\quad 50$

3. MATERIAIS E MÉTODOS 53

3.1. INTRODUÇÃO 53

3.2. COLETA E CARACTERÍSTICAS DOS MATERIAIS UTILIZADOS 53 
$\begin{array}{lll}3.2 .2 \text { Solos } & 54\end{array}$

3.3. CARACTERIZAÇÃO E CLASSIFICAÇÃO DOS MATERIAIS 56

3.3.1 Caracterização dos materiais $\quad 56$

$\begin{array}{ll}\text { 3.3.2 Classificação dos solos } & 58\end{array}$

$\begin{array}{lll}3.3 .3 \text { Cal } & 60\end{array}$

3.4. COMPOSIÇÃO DAS MISTURAS E ENSAIOS DE COMPACTAÇÃO 61

3.5. PROPRIEDADES MECÂNICAS DAS MISTURAS 63

3.5.1. Ensaio de compressão simples 63

3.5.1.1 Moldagem dos corpos-de-prova 63

3.5.1.2 Ensaio dos corpos-de-prova 65

3.5.1.3 Determinação da resistência à compressão simples $\quad 65$ e deformabilidade

$\begin{array}{ll}\text { 3.5.2.1 Moldagem dos corpos-de-prova } & 67\end{array}$

3.5.2.2 Ensaio dos corpos-de-prova 67

3.5.2.3 Determinação da resistência à compressão
diametral

3.5.3. Ensaios triaxiais cíclicos 69

3.5.3.1 Moldagem dos corpos-de-prova 69

3.5.3.2 Ensaio dos corpos-de-prova 70

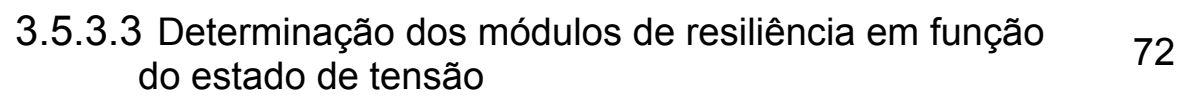

3.6. ESTUDO DA INFLUÊNCIA DO TEMPO DE CURA

$\begin{array}{ll}\text { 3.7. } & \text { ENSAIOS AMBIENTAIS } \\ \end{array}$

3.8. ANÁLISE DOS RESULTADOS 76

3.8.1. Método de aceitação dos resultados 76

$\begin{array}{ll}\text { 3.8.2. Análise de variância } & 77\end{array}$ 
4. APRESENTAÇÃO E ANÁLISE DOS RESULTADOS

4.1. CONSIDERAÇÕES INICIAIS $\quad 79$

4.2. ANÁLISE DOS RESULTADOS DOS ENSAIOS DE 79 COMPACTAÇÃO

4.2.1 Determinação do teor de resíduo máximo na mistura 79

4.2.2 Misturas solo-cal, solo-resíduo e solo-resíduo-cal 82

4.3 PROPRIEDADES MECÂNICAS DAS MISTURAS 92

4.3.1. Ensaio de compressão simples 92

4.3.1.1. Resistência à compressão simples imediata 93

$\begin{array}{lll}\text { 4.3.1.1.1. Solo-Resíduo } & 93\end{array}$

4.3.1.1.2. Solo-Resíduo-Cal e Solo-Cal 95

4.3.1.2. Resistência à compressão simples aos 7
dias de cura simples

4.3.1.3. Influência do tempo de cura na compressão 102

4.3.1.4. Influência da imersão em água na resistência 106
à compressão simples

4.3.1.5. Influência do tempo de cura para misturas ensaiadas após imersão em água na resistência à compressão simples

4.3.2. Ensaio de compressão simples - módulo tangente

4.3.2.1. Influência do tempo de cura no módulo tangente inicial

4.3.2.2. Influência da imersão em água no módulo tangente inicial

4.3.2.3. Influência do tempo de cura para misturas ensaiadas após imersão em água no módulo tangente inicial

4.3.3. Ensaio de compressão diametral

4.3.3.1. Influência do tempo de cura na compressão diametral

4.3.3.2. Influência da imersão em água na resistência à compressão diametral

4.3.3.3. Influência do tempo de cura para misturas ensaiadas após imersão em água na resistência à compressão diametral 
4.3.4.1. Modelagem do $M_{R}$ em função do estado de tensão

4.3.4.2. Módulo de resiliência das misturas de solocal

4.3.4.3. Módulo de resiliência das misturas de soloresíduo-cal

4.3.4.4. Avaliação do $M_{R}$ para uma estrutura de pavimento hipotética

4.4 ENSAIOS AMBIENTAIS

5. CONCLUSÕES

5.1. CONSIDERAÇÕES INICIAIS

5.2. PRINCIPAIS CONCLUSÕES QUANTO A COMPACTAÇÃO DAS MISTURAS

5.3. DESEMPENHO DAS MISTURAS SOLO-RESÍDUO, SOLO-CAL E SOLO-RESÍDUO-CAL AOS 7 DIAS DE CURA

5.4. INFLUÊNCIA DO TEMPO DE CURA NAS MISTURAS SOLO-CAL E SOLO-RESÍDUO-CAL COM 10\% DE CAL

5.5. INFLUÊNCIA DA IMERSÃO EM ÁGUA NAS MISTURAS SOLOCAL E SOLO-RESÍDUO-CAL COM 10\% DE CAL

5.6. PRINCIPAIS CONCLUSÕES QUANTO AOS ENSAIOS AMBIENTAIS

5.7. CONSIDERAÇÕES FINAIS E RECOMENDAÇÕES PARA TRABALHOS FUTUROS 


\section{INTRODUÇÃO}

\subsection{IMPORTÂNCIA DO PROBLEMA}

Os resíduos da produção de papel são definidos como sendo o material que sobra dos processos inerentes à fabricação do papel os quais não são incorporados ao produto final. Estes resíduos são substâncias que representam ônus às indústrias de papel e celulose, uma vez que necessitam de tratamento e transporte para seu destino final.

Os resíduos provenientes das indústrias de papel e celulose derivam-se dos processos utilizados para extração das fibras de celulose contidas na matriz de lignina. A extração da pasta de celulose é obtida através da separação das fibras de celulose da matriz de lignina. Para este fim, vários processos podem ser utilizados, tais como: processo de pasta mecânica; processo com soda; processo sulfito e processo sulfato (Kraft). O processo Kraft é o mais difundido por apresentar as vantagens de possuir ciclos de cozimentos mais curtos que os demais, produzir polpas de alta resistência e ter um eficiente sistema de recuperação dos reagentes usados.

A indústria de papel e celulose representa um dos mais expressivos setores industriais do mundo, sendo de grande importância para a economia mundial. Na América do Sul, devido à grande disponibilidade de recursos florestais, o Brasil e o Chile são os 
maiores produtores de celulose. O Brasil apresenta uma produção em torno de 6 milhões de toneladas de polpa por ano, dos quais $98 \%$ são branqueadas, segundo pesquisas da Unicamp (2004).

A produção de papel passou por evoluções ao longo dos anos, que possibilitou o melhoramento da qualidade e velocidade de produção, fazendo com que este setor industrial produzisse um aumento na capacidade da produção, acarretando um aumento do volume de resíduos produzidos pela indústria de papel e celulose. O alto consumo de papel e seus métodos de produção endossam o rol das atividades humanas mais nocivas ao planeta. O consumo mundial cresceu mais de seis vezes desde a metade do século $\mathrm{XX}$, segundo dados do Worldwatch Institute, podendo chegar a mais de $300 \mathrm{~kg}$ per capita ao ano em alguns países. No Brasil este consumo no ano de 2007 foi de 42,2 kg per capita ao ano. Para produzir 1 tonelada de papel são necessárias 2 a 3 toneladas de madeira, uma grande quantidade de água (mais do que qualquer outra atividade industrial), e muita energia (está em quinto lugar na lista das que mais consomem energia).

O ponto crítico da produção de papel acontece quando as polpas são branqueadas. O branqueamento é o principal problema de poluição do setor, com sérios danos para a natureza. No processo onde a celulose é branqueada, utilizam-se compostos clorados constituídos por produtos químicos altamente tóxicos, evidenciando um sério risco para a saúde humana e ao meio ambiente.

No mundo, diversas pesquisas se preocupam com uma solução para o descarte dos resíduos da fabricação de papel e celulose. Estudam-se as reações e o comportamento deste material, com o objetivo de reutilizá-lo em plantios florestais, na fabricação de blocos cerâmicos, na composição de argamassas, na utilização como material de base e sub-base de pavimentos, etc. 
No Brasil, o interesse de se estudar a utilização de resíduos da indústria de papel na construção rodoviária ainda é muito recente, destacando-se o trabalho de Molina (2004) com a utilização de lama de calcários e dregs e de Machado et al. (2004) com utilização de lama de calcário.

A construção rodoviária oferece boas oportunidades para reciclar resíduos industriais. A carência de materiais geotécnicos considerados nobres para a utilização na pavimentação em várias regiões do país alimenta a procura por materiais que possam substituir os convencionais ou que, através de misturas, possam melhorar as características destes considerados inapropriados para a construção de bases e sub-bases. Embora sejam poucos, os estudos para a aplicação dos resíduos da indústria de papel e celulose na construção rodoviária mostram-se promissores. Porém, é extremamente importante avaliar estes materiais, para assegurar que as misturas utilizadas com resíduos tenham um desempenho mecânico aceitável e um baixo potencial poluente.

\subsection{OBJETIVO}

O objetivo principal desse estudo é analisar a resistência e a deformabilidade de misturas constituídas por três tipos diferentes de solos e resíduos da fabricação de papel (lama de calcário e dregs), estabilizadas com cal.

Complementarmente, será analisado o comportamento mecânico de misturas solocal, compostas por dois tipos diferentes de solos quanto ao comportamento laterítico, mas com classificação HBR (AASHTO - M145) coincidente, procurando-se identificar a influência da gênese dos solos na resistência e deformabilidade das misturas. 


\subsection{ORGANIZAÇÃO DO TRABALHO}

Este trabalho foi desenvolvido na forma de dissertação de mestrado, dividido em cinco capítulos. O primeiro é a presente introdução e os quatro restantes foram organizados da seguinte maneira:

O capítulo 2 apresenta a revisão bibliográfica, destacando-se os aspectos mais relevantes para o desenvolvimento da pesquisa. São abordados os processos de produção da pasta de celulose, do papel e informações a respeito da origem dos resíduos gerados.

O capítulo 3 descreve a caracterização dos materiais (solos, resíduo e cal), os critérios para a escolha da composição das misturas, os procedimentos de preparação dos corpos-de-prova, a descrição dos ensaios utilizados na determinação das propriedades mecânicas e o método de análise usado na interpretação dos resultados.

No capítulo 4 são apresentados e discutidos os resultados obtidos a partir dos ensaios de laboratório, com destaque para o máximo teor trabalhável de resíduo nas misturas, a influência do tipo de solo e da adição da cal, o efeito da ação da água e o efeito do tempo de cura.

O capítulo 5 apresenta as conclusões obtidas a partir da análise dos resultados laboratoriais e recomendações para futuros trabalhos. 


\section{REVISÃO BIBLIOGRÁFICA}

\subsection{INTRODUÇÃO}

A indústria de papel e celulose é a terceira indústria mais poluidora da América do Norte, superada apenas pelas indústrias de produtos químicos orgânicos e de petróleo, segundo a Canadian Environmental Protection (1991).

Em 2007, dentre os maiores produtores de papel, destacavam-se os Estados Unidos e a China com, respectivamente, 83,6 e 73,5 milhões de toneladas, enquanto que o Brasil ocupava a $12^{a}$ posição com 9,0 milhões de toneladas. Já no setor de celulose os maiores produtores eram os Estados Unidos e o Canadá com 53,5 e 22,3 milhões de toneladas, respectivamente, e o Brasil ocupando a $6^{a}$ posição com 12,1 milhões de toneladas. Neste mesmo ano, no Brasil, o crescimento na produção de celulose foi de $7,6 \%$, enquanto que o de papel registrou um aumento de $5,5 \%$, em relação ao ano de 2006 , segundo dados da Associação Brasileira de Celulose e Papel (BRACELPA, 2007).

Nas indústrias de papel e celulose a quantidade aproximada de resíduos produzidos tem sido de 48 toneladas para cada 100 toneladas de celulose produzida (BELLOTE et al., 1998). Dentre os resíduos sólidos produzidos, destacam-se uma mistura de lama de calcário e os dregs, que é obtida na proporção de 10:1 (MOLINA, 2004). Os dois resíduos sólidos 
são obtidos durante o processo de recuperação da lixívia utilizada no cozimento da madeira para a extração da lignina e conseqüentemente separação das fibras da celulose. Segundo a legislação ambiental brasileira, os resíduos industriais devem ser eliminados de forma apropriada. Tradicionalmente, estes resíduos são depositados em aterros sanitários ou em áreas controladas. Estas formas de armazenagem se mostram cada vez mais dispendiosas devido às crescentes exigências ambientais das autoridades competentes e devido ao fato de haver uma disponibilidade pequena de áreas adequadas para esse tipo de armazenagem.

\subsection{PRODUÇÃO DE PASTA DE CELULOSE E PAPEL}

A madeira passou a ser a principal matéria-prima para fabricação de papel em meados do século XIX. As fibras naturais com as quais se produz a pasta de celulose encontram-se nas diferentes espécies de árvores. No Brasil, a indústria de papel e celulose utiliza a madeira do eucalipto e do pinheiro. Cada espécie produz fibras de celulose com características específicas, o que confere ao papel propriedades especiais.

Dentre as indústrias, a de papel e celulose é tradicionalmente uma das maiores produtoras de resíduos. Todavia, esta enfrenta o desafio de reduzir a demanda destes resíduos investindo em melhorias nos processo e controles de fabricação, de forma a minimizar os impactos ambientais. Os resíduos gerados pela indústria de papel, derivam-se dos processos utilizados para extração das fibras de celulose contidas na matriz de lignina. Para se separar as fibras de celulose da matriz de lignina, vários processos podem ser utilizados, tais como: processo de pasta mecânica; processo com soda; processo sulfito e processo sulfato (Kraft). 
O processo Kraft, usado na extração da pasta de celulose, é o mais difundido por apresentar as vantagens de possuir ciclos de cozimentos mais curtos que os demais, produzir polpas de altas resistências e ter um eficiente sistema de recuperação dos reagentes usados. A Figura 2.1 apresenta um fluxograma para esquematizar as etapas do processo de produção de pasta de papel e celulose.

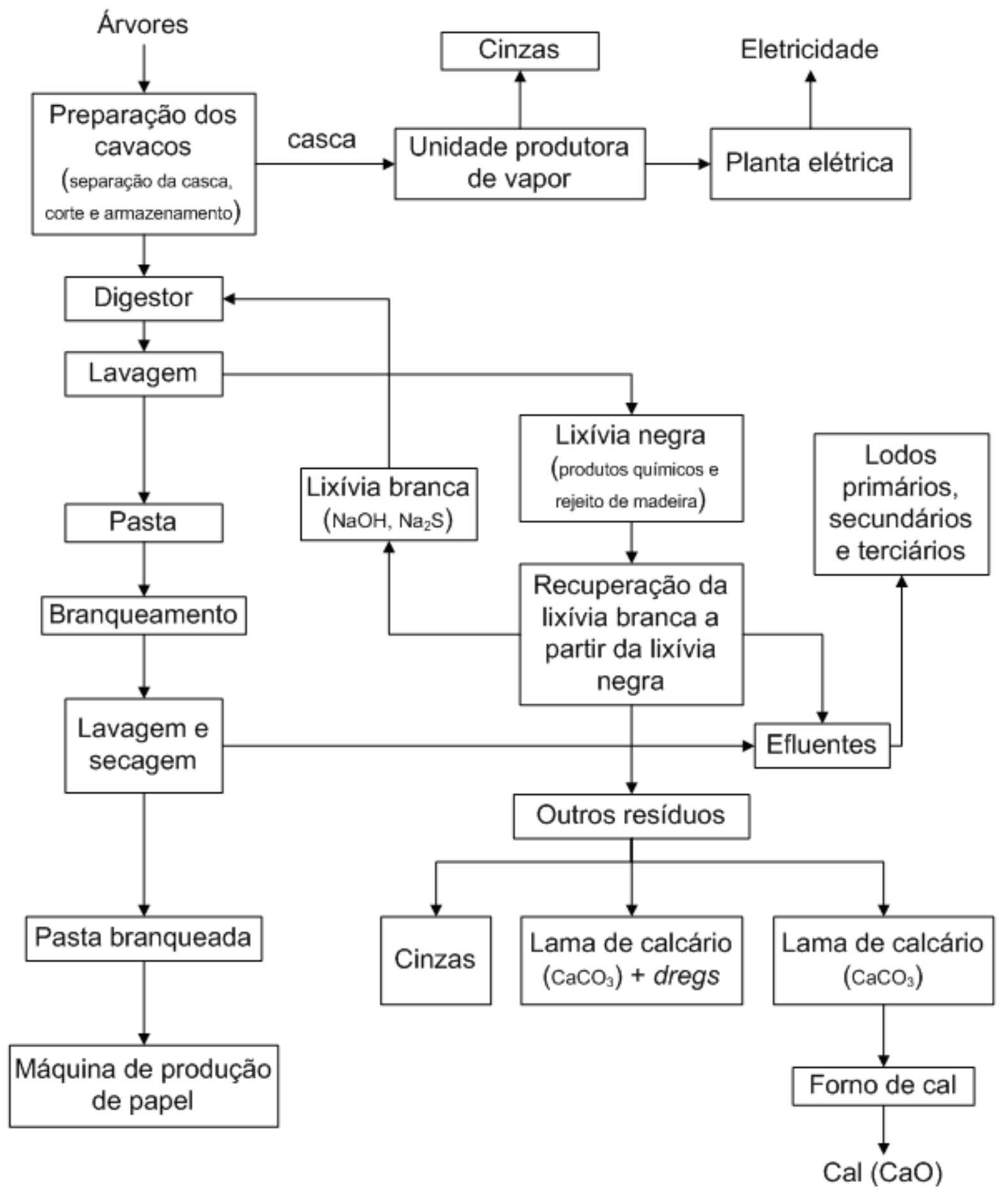

Figura 2.1 - Processo de produção da pasta de celulose 
Antes que a matéria-prima seja submetida ao processo que a transformará em pasta de celulose e papel, ela deve ser preparada para que a qualidade do produto final não seja comprometida. A madeira é encaminhada para as linhas de preparação onde é descascada e cortada em cavacos (pequenos pedaços de madeira), pois a casca das árvores, pobre em fibras de celulose, não tem qualquer aproveitamento para a produção de pasta de papel, causando um maior consumo de reagentes químicos nas etapas de extração da pasta de celulose e de branqueamento e dificultando a lavagem de depuração da polpa.

O branqueamento é o ponto crítico da produção de papel, pois é nele que se gera o principal problema de poluição do setor, com sérios danos para a natureza. No branqueamento da celulose são utilizados compostos clorados constituídos por produtos químicos altamente tóxicos, evidenciando um sério risco para a saúde humana e para o meio ambiente.

O cozimento dos cavacos de madeira é realizado através da utilização de uma solução rica em produtos químicos, à qual se dá o nome de licor branco. O digestor é um grande tubo cilíndrico onde se introduzem os cavacos juntamente com o licor branco. É neste processo que há separação entre a lignina e a celulose. Através das reações químicas, se verifica entre a madeira e o licor branco, que grande parte da lignina liberta-se das fibras de celulose, dissolvendo-se no licor. A lignina misturada com o licor é extraída no meio do digestor, e a esta mistura designa-se pelo nome de licor negro, devido à tonalidade escura apresentada pela dissolução da lignina. Na saída do digestor, obtém-se a pasta crua. Em seguida, faz-se um branqueamento com produtos químicos à base de óxidos, conferindo-lhe progressivamente uma tonalidade branca. 


\subsubsection{Processo Kraft ou processo do sulfato}

O propósito deste processo, totalmente químico, é o de livrar as fibras de celulose de outros componentes da madeira, principalmente a lignina. A celulose e a lignina são separadas com o auxílio de uma mistura denominada lixívia branca, constituída por hidróxido de sódio $(\mathrm{NaOH})$, sulfeto de sódio $\left(\mathrm{Na}_{2} \mathrm{~S}\right)$ e pequenas quantidades de carbonato de sódio $\left(\mathrm{Na}_{2} \mathrm{CO}_{3}\right)$. A mistura apresenta um pH acima de 12 e o processo é realizado a temperaturas entre $160^{\circ} \mathrm{C}$ e $180^{\circ} \mathrm{C}$, por 1 a 3 horas, sendo a lignina despolimerizada e dissolvida (BIERMANN, 1993).

Após a conclusão desta etapa são obtidas, a pasta de celulose não branqueada e a lixívia negra. Esta última é composta pelos produtos químicos utilizados no processo de dissolução da celulose e madeira dissolvida. Posteriormente, a celulose não branqueada e a lixívia negra são descarregadas do digestor para então serem separadas por sistemas de clivagem centrífuga e filtragem sob vácuo, com o auxílio de água.

Este processo, denominado de lavagem de celulose, é realizado para permitir que a celulose prossiga limpa para o processo de branqueamento, e o restante prossiga para o processo de reciclagem química, onde a finalidade é recuperar produtos químicos e gerar energia.

O processo de branqueamento é iniciado com a celulose lavada, que ainda se mantém na cor marrom devido à presença de lignina oxidada, a qual é removida através da ação do dióxido de cloro $\left(\mathrm{ClO}_{2}\right)$. Após o branqueamento, a pasta de celulose volta a ser lavada, secada, e armazenada para o abastecimento das máquinas de produção de papel (BIERMANN, 1993; NOLASCO, 1998; SANTOS et al., 2001). 
Para iniciar a produção de papel, utiliza-se a pasta de celulose em uma suspensão diluída, a qual recebe os aditivos adequados. Essa suspensão alimenta um mecanismo complexo, ilustrado na Figura 2.2, que se divide em duas seções principais:

- Seção úmida: a pasta de celulose é depositada sobre uma rede metálica movimentada por rolos. Durante este processo a pasta perde água por gravidade e posteriormente por sucção (produzida por cilindros aspiradores).

- Seção seca: procede-se a secagem do papel por meio de cilindros giratórios aquecidos com vapor de água à baixa pressão. Neste processo, a folha de papel perde até $70 \%$ da sua água.

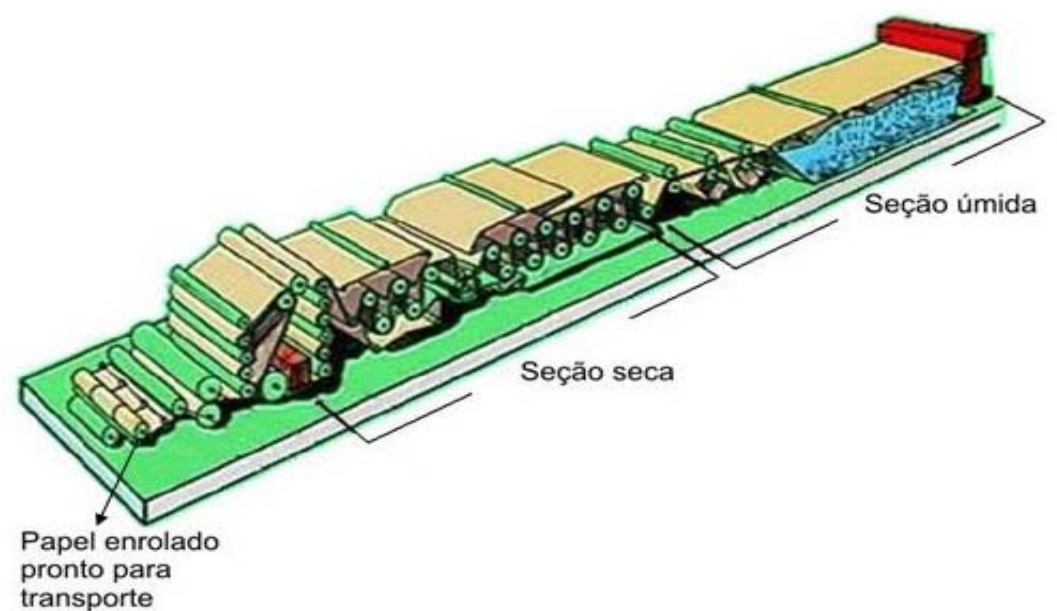

Figura 2.2 - Seções de uma máquina de papel

O processo finaliza-se com o papel enrolado em bobinas, que são enviadas às fábricas de produtos de papel, para sua conversão em produtos tais como: papelão, papel de impressão, papel sanitário e outros (BIERMANN, 1993; PAPER INDUSTRY INTERNATIONAL HALL OF FAME, 1993).

O processo de reciclagem química se mostra mais complexo que a própria produção da pasta de celulose. Assim, este processo é explicado mais detalhadamente no Item 2.2.2. 


\subsubsection{Processo de reciclagem química}

A idéia original de adicionar sulfato de sódio $\left(\mathrm{Na}_{2} \mathrm{SO}_{4}\right)$ no evaporador de lixívia negra, para baixar o ponto de ebulição, originou o processo kraft. $\mathrm{Na}$ caldeira de recuperação química, a lixívia negra é submetida à combustão para fundir seus componentes inorgânicos no chamado smelt, e queimar seus componentes orgânicos para gerar vapor, que é convertido em eletricidade. A lixívia negra que apresenta inicialmente uma concentração de $15 \%$ de sólidos, no final do processo alcança aproximadamente uma concentração de $65 \%$. Esta nova técnica só é rentável devido à recuperação dos produtos químicos utilizados no processo Kraft, e a geração de energia necessária à deslignificação. A Figura 2.3 detalha o esquema de recuperação química utilizada no processo Kraft.

O smelt é composto por sulfeto de sódio $\left(\mathrm{Na}_{2} \mathrm{~S}\right)$ e carbonato de sódio $\left(\mathrm{Na}_{2} \mathrm{CO}_{3}\right)$. Para repor as perdas de sulfeto de sódio $\left(\mathrm{Na}_{2} \mathrm{~S}\right)$ no ciclo, adiciona-se sulfato de sódio $\left(\mathrm{Na}_{2} \mathrm{SO}_{4}\right)$ antes da combustão na caldeira de recuperação.

O processo químico na caldeira de recuperação química para gerar o smelt pode ser esquematizado conforme as reações químicas apresentadas a seguir:

Conversão de sais de sódio: $2 \mathrm{NaOH}+\mathrm{CO}_{2} \Rightarrow \mathrm{Na}_{2} \mathrm{CO}_{3}+\mathrm{H}_{2} \mathrm{O}$;

Recuperação dos compostos químicos originais: $\mathrm{Na}_{2} \mathrm{SO}_{4}+4 \mathrm{C} \Rightarrow \mathrm{Na}_{2} \mathrm{~S}+4 \mathrm{CO}_{2}$.(2.2)

Após o fim da combustão, o smelt, composto basicamente por sais, é dissolvido em água. O resultado da mistura, destes sais com a água, é uma solução verde denominada lixívia verde. Posteriormente, a lixívia verde passa por um processo de caustificação, que permite a recuperação da lixívia branca, que retorna novamente ao processo para a separação da celulose, fechando o ciclo (MUNIZ \& ANDRADE, 1999). 


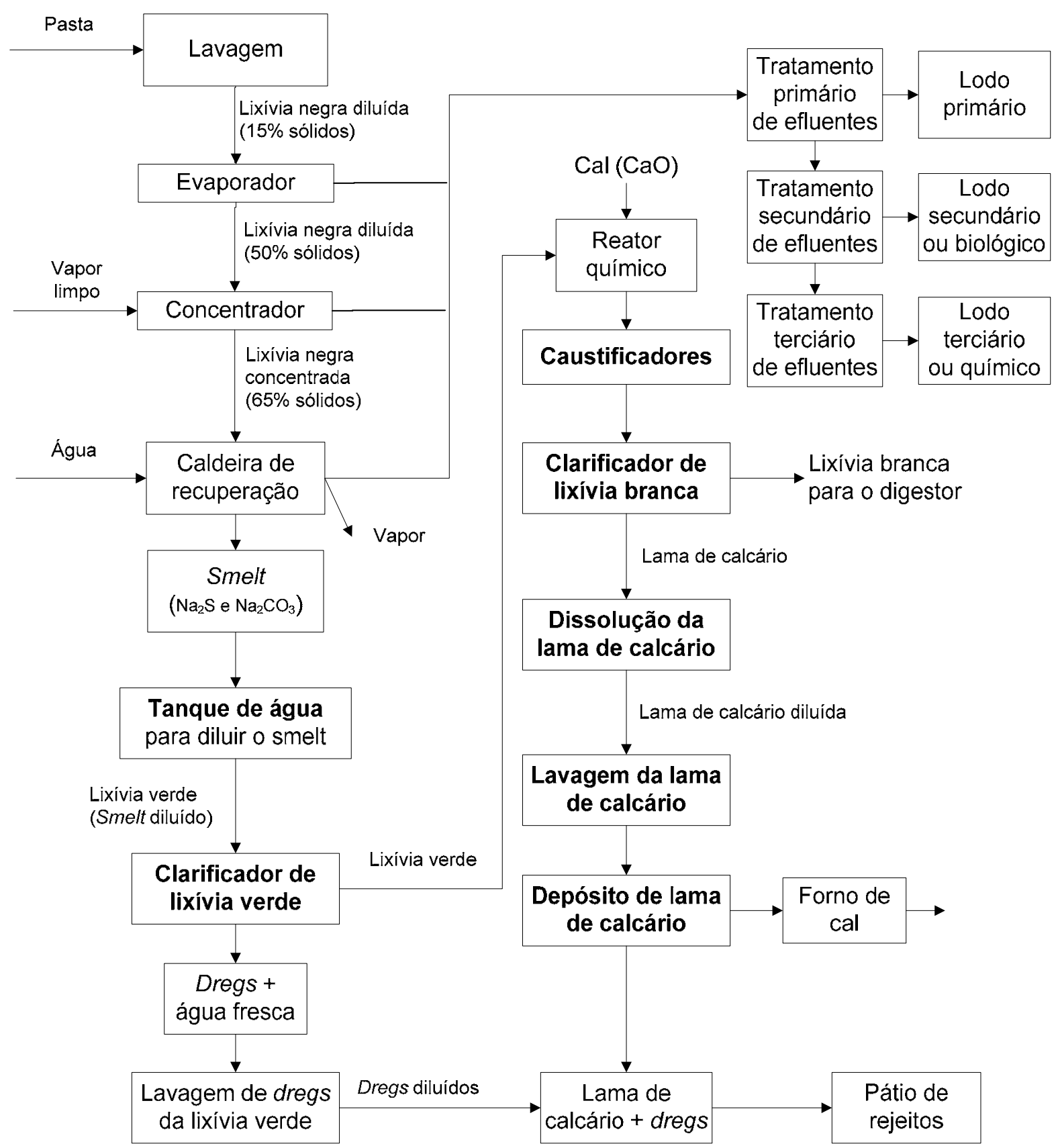

Figura 2.3 - Processo de recuperação química

Antes da lixívia verde se dirigir à caustificação, ela deve passar por um processo de clarificação. O processo de clarificação consiste em remover as impurezas por sedimentação (dregs) que causam a coloração verde. Os dregs são impurezas oriundas principalmente do carbono, e também de hidróxidos e sulfetos de metais. Estas partículas, se não removidas do licor verde, prejudicam a filtração da lama de cal e tendem a acumularse no sistema (BIERMANN, 1993). 
No setor de caustificação, são adicionados dois produtos químicos: a cal virgem (óxido de cálcio - $\mathrm{CaO})$ e a cal hidratada $\left(\mathrm{Ca}(\mathrm{OH})_{2}\right)$. O óxido de cálcio $(\mathrm{CaO})$ utilizado é obtido através de recuperações químicas anteriores, cujo produto químico sofre hidratação em contato com a lixívia verde convertendo-se em cal hidratada $\left(\mathrm{Ca}(\mathrm{OH})_{2}\right)$. Assim, a cal hidratada reage com o carbonato de sódio $\left(\mathrm{Na}_{2} \mathrm{CO}_{3}\right)$, formando a soda cáustica (hidróxido de sódio - $\mathrm{NaOH})$ e carbonato de cálcio $\left(\mathrm{CaCO}_{3}\right)$ (BIERMANN, 1993). O processo químico é o seguinte:

$$
\begin{aligned}
& \text { Hidratação da cal: } \mathrm{CaO}+\mathrm{H}_{2} \mathrm{O} \Rightarrow \mathrm{Ca}(\mathrm{OH})_{2} ; \\
& \text { Recuperação da soda cáustica: } \mathrm{Ca}(\mathrm{OH})_{2}+\mathrm{Na}_{2} \mathrm{CO}_{3} \Leftrightarrow 2 \mathrm{NaOH}+\mathrm{CaCO}_{3} \text {. }
\end{aligned}
$$

A recuperação da soda cáustica $(\mathrm{NaOH})$, principal composto da lixívia branca, deixa como resíduo a lama de calcário (carbonato de cálcio - $\mathrm{CaCO}_{3}$ ), que é tratada em um forno de alta temperatura para recuperar o óxido de cálcio (EPA, 2002), conforme esquema apresentado a seguir:

$$
\mathrm{CaCO}_{3} \Rightarrow \mathrm{CaO}+\mathrm{CO}_{2}
$$

Neste processo de recuperação da cal virgem (óxido de cálcio - $\mathrm{CaO}$ ), parte da lama de calcário não é aproveitada. Assim, ao término do processo de recuperação química, a lama de calcário e os dregs são misturados para disposição em áreas controladas ou aterros sanitários.

Além das cinzas, provenientes da queima de resíduos orgânicos, lama de calcário e os dregs, o processo de recuperação química gera também lodos, que são provenientes do tratamento de efluentes aquosos.

Os efluentes aquosos são tratados para que seja possível a reutilização de parte deste material e para melhorar as características deste produto, a fim de diminuir a poluição 
quando descartados nos rios. Os métodos de tratamento de efluentes mais utilizados pelas indústrias de celulose e papel são:

- Métodos físicos: são os métodos de sedimentação, flotação e filtração, sendo o de flotação o mais usual, por possuir boa ação de clarificação e remoção de partículas sólidas dos efluentes. Os resíduos gerados pelos métodos físicos são denominados de lodos primários.

- Métodos bioquímicos ou biológicos: são os mais recomendados ultimamente, consistindo no desenvolvimento de microorganismos que atuam de forma aeróbica para a oxidação do material orgânico responsável pela queda de oxigênio na água. Os resíduos gerados por estes métodos são denominados de lodos secundários.

- Métodos químicos: são muito utilizados em estações de tratamento de água e estações de tratamento de esgoto convencionais de centros urbanos, consiste na precipitação química do material suspenso para reduzir a turbidez da água. Os resíduos gerados por este método são chamados de lodos terciários (BIERMANN, 1993; FONSECA et al, 2003; PIOTTO, 2003).

Entre os lodos obtidos pelos métodos de tratamento de efluentes, apenas o lodo primário e o lodo secundário podem ser utilizados na agricultura como adubo, caso contrario, estes lodos, da mesma forma que o lodo terciário, deve ser depositado em áreas controladas ou em aterros sanitários. 


\subsection{CARACTERIZAÇÃO DOS RESÍDUOS GERADOS NA PRODUÇÃO DE CELULOSE}

Os resíduos nas indústrias de celulose e papel são resultados do controle dos agentes poluentes. A Tabela 2.1 e a Figura 2.4 apresentam, respectivamente, características e composição dos resíduos sólidos resultantes do processo kraft de produção de pasta de celulose.

Tabela 2.1 - Resíduos sólidos de fábricas brasileiras de pasta de celulose que utilizam o processo Kraft, 1995/1996

\begin{tabular}{|c|c|c|c|c|}
\hline Tipo de resíduo & Fonte geradora & $\begin{array}{c}\text { Volume gerado } \\
\text { (\% / mês) }\end{array}$ & $\begin{array}{c}\text { Volume específico } \\
\text { Kg/ADT }\end{array}$ & Destino final \\
\hline Cascas & $\begin{array}{l}\text { Pátio de } \\
\text { madeira }\end{array}$ & 23,90 & $30,86-40,43$ & $\begin{array}{l}\text { Aterro / } \\
\text { Floresta }\end{array}$ \\
\hline Cinzas & Caldeiras & 11,00 & $14,23-30,22$ & $\begin{array}{l}\text { Aterro / } \\
\text { Floresta }\end{array}$ \\
\hline Dregs & Caustificação & 11,80 & $14,30-30,22$ & $\begin{array}{c}\text { Aterro / } \\
\text { Reciclagem }\end{array}$ \\
\hline Grits & Caustificação & 2,30 & $2,93-7,34$ & $\begin{array}{c}\text { Aterro / } \\
\text { Reciclagem }\end{array}$ \\
\hline Lama de calcário & $\begin{array}{l}\text { Caustificação / } \\
\text { Forno de cal }\end{array}$ & 22,20 & $28,62-53,83$ & $\begin{array}{l}\text { Aterro / } \\
\text { Floresta }\end{array}$ \\
\hline Resíduo Doméstico & Geral & 2,70 & $3,46-3,72$ & $\begin{array}{c}\text { Aterro / } \\
\text { Reciclagem }\end{array}$ \\
\hline Lodo de ETE & $\begin{array}{l}\text { Tratamento de } \\
\text { efluentes }\end{array}$ & 16,70 & $21,56-29,40$ & $\begin{array}{l}\text { Aterro / } \\
\text { Floresta }\end{array}$ \\
\hline Outros & $\begin{array}{c}\text { Entulhos / } \\
\text { Rejeitos, etc. }\end{array}$ & 9,50 & $5,85-12,07$ & $\begin{array}{l}\text { Aterro / } \\
\text { Doação }\end{array}$ \\
\hline Total & & 100,00 & $127,81-181,21$ & \\
\hline
\end{tabular}

Fonte: Alberto C. O. Filho et al. (1997)

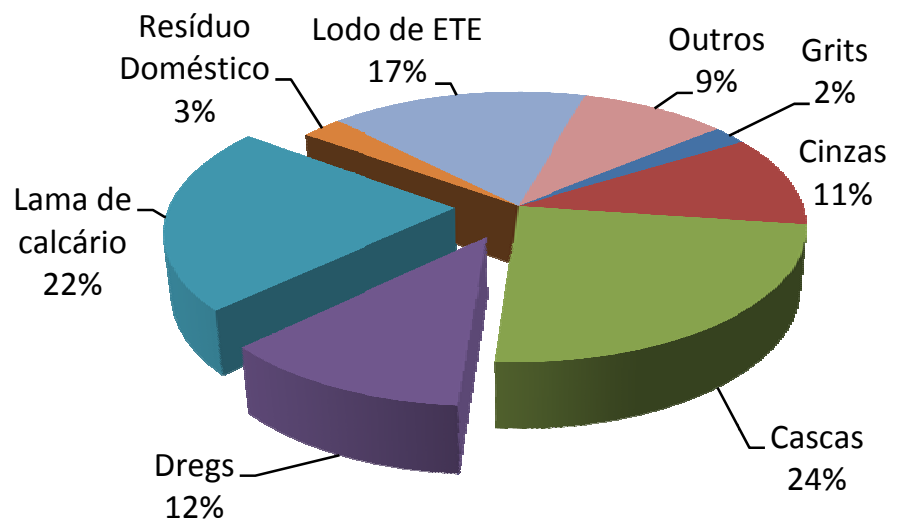

Figura 2.4 - Composição do resíduo em porcentagem 
Segundo a Companhia Pernambucana de Meio Ambiente - CPRH (1998), de modo geral, os resíduos da indústria de papel não são classificados como perigosos, sendo enquadrados como classe II de acordo com a Norma ABNT (NBR 10.004,2004).

Dentre os resíduos da indústria de papel, a lama de calcário e os dregs foram os materiais estudados neste trabalho. O interesse por estudá-los foi despertado por serem dispostos de forma conjunta, serem produzidos em grandes volumes e possuírem grande quantidade de compostos calcários, que geralmente, quando misturados aos solos, produzem melhorias no seu comportamento mecânico (GRAVES, 1987; BHUIYAN, 1995; MOLINA, 2004).

\subsubsection{Lama de calcário}

A lama de calcário tem como principal componente o carbonato de cálcio $\left(\mathrm{CaCO}_{3}\right)$, mas é composta também por pequenas quantidades de outros carbonatos e hidróxidos de cálcio, magnésio e sódio. Este resíduo é o resultado da clarificação da lixívia branca, e que, após ser extraído da mesma, apresenta uma porcentagem de $35 \%$ de sólidos (BIERMANN, 1993).

Posteriormente, a lama de calcário sofre uma lavagem para remoção dos hidróxidos de sódio $\left(\mathrm{Na}(\mathrm{OH})_{2}\right)$ e óxidos de sódio $\left(\mathrm{Na}_{2} \mathrm{O}\right)$ que correspondem de $15 \%$ a $20 \%$ da lama de calcário. Se o processo for aplicado corretamente, apenas $1 \%$ dos hidróxidos e óxidos de sódio deixam de ser removidos da lama de calcário. Após a lavagem, a lama de calcário é concentrada até atingir um teor de $60 \%$ a $70 \%$ de sólidos, onde parte segue para o forno de cal e o restante é disposto juntamente com os dregs em áreas controladas ou aterros sanitários (BIERMANN, 1993; NCASI, 2003). 


\subsubsection{Dregs}

Os dregs são impurezas inertes, não solubilizadas, removidas por sedimentação do processo de clarificação da lixívia verde. Este resíduo, segundo Biermann (1993), consiste em carbono ( $50 \%$ ou mais) e outros materiais (metais insolúveis, carbonetos, sulfatos, sulfetos, hidróxidos e silicatos) e que resulta em um volumoso material de cor preta. Os dregs devem ser removidos da lixívia verde, pois prejudicam a filtração de lama de calcário e tendem a se acumular no sistema (COHN \& RIBEIRO, 2002).

Após se separar os dregs da lixívia verde, o resíduo é lavado para remover os compostos de sódio nele presentes. Para a recuperação destes compostos, o resíduo passa por sucessivas etapas de diluição e sedimentação, podendo chegar a uma recuperação de até $95 \%$ dos compostos de sódio (BIERMANN, 1993). Depois da lavagem, os dregs são bombeados para fora do sistema e depositados junto à lama de calcário no pátio de resíduos.

\subsection{UTILIZAÇÃO DOS RESÍDUOS DA INDÚSTRIA DE PAPEL E CELULOSE NA CONSTRUÇÃO RODOVIÁRIA}

A utilização de resíduos industriais na construção rodoviária gera benefícios, não só reduzindo a quantidade destes materiais para as formas convencionais de disposição, mas também promovendo novos materiais de construção com propriedades significantes. O uso dos resíduos na construção rodoviária pode até agregar valores, ao que antes era considerado apenas como um material dispendioso (U.S. ARMY CORPS OF ENGINEERS, 1999).

Avaliar a utilização dos resíduos da indústria de papel na pavimentação é extremamente importante para assegurar um desempenho aceitável e satisfazer critérios de 
engenharia, ambientais e econômicos. Os resíduos não devem apresentar efeitos negativos ao desempenho dos pavimentos, nem afetar a saúde dos trabalhadores durante a construção ou dos usuários durante o uso dos pavimentos, bem como não ameaçar o meio ambiente. Assim, devido também à grande importância da construção rodoviária para o comércio e para a mobilidade das pessoas, estudos criteriosos devem ser desenvolvidos para que não se permita que os pavimentos se tornem simplesmente um "aterro sanitário longitudinal".

O estudo a respeito do uso de resíduos da indústria de papel e celulose na construção rodoviária ainda é recente, existindo poucas publicações se tratando do assunto. Atualmente registram-se nessa área os trabalhos de Lathinen et. al. (2001), Machado et. al. (2004), Molina (2004) e Zhou (1999).

As análises de Zhou (1999) constataram que os teores ótimos de resíduos nas misturas eram de $10 \%$, e que as resistências mecânicas das misturas variam significativamente, de acordo com o tipo de solo, sendo que os maiores valores foram observados em solos com maiores teores de argila. De acordo com os estudos de Zhou, era esperado que a lama-de-calcário exibisse um comportamento similar ao da cal hidratada, quando utilizada para a estabilização de solo com grandes quantidades de teores de argila, pelo fato deste resíduo ter elevado teor de cálcio.

A influência do tempo de cura e da umidade de compactação se faz presente, visto que, tempos de cura maiores e teores de umidades inferiores à ótima aumentam a resistência das misturas. Em estudos quanto à toxidade da lama-de-calcário e cinza volante, determinou-se que estes materiais podem ser classificados como não perigosos ao meio ambiente, e que as concentrações de metais pesados eram menores que as permitidas pelos regulamentos ambientais vigentes (ZHOU, 1999). 
Lathinen et. al. (2000) apresentaram resultados de uma pesquisa com cinzas volantes provenientes da queima da casca e serragem da produção de papel. As pesquisas foram realizadas utilizando ensaios em laboratório e em campo, onde se constatou que as cinzas volantes da indústria de papel podem ser utilizadas para estabilizar solos, melhorando sua resistência e estabilidade. O estudo teve sucesso no desenvolvimento da nova mistura para a aplicação em construções rodoviárias de baixo volume de tráfego.

Nesse estudo, analisaram-se ainda misturas de solo com lodo (resíduo da fabricação de papel com alto teor de matéria orgânica) e cinza volante. Embora o lodo, como se averiguou, não possa ser utilizado isoladamente, por apresentar baixa resistência às cargas de tráfego veicular e às condições ambientais, mas em conjunto com os materiais citados acima (solo e cinza volante) desenvolveu excelentes resultados (LATHINEN et. al., 2000).

No estudo desenvolvido por Molina (2004), utilizou-se um resíduo da indústria de papel constituído por lama-de-calcário e dregs na proporção de 10:1, respectivamente. Os resultados dos estudos demonstraram que a adição do resíduo não melhora as propriedades mecânicas das misturas compactadas, necessitando da adição de um estabilizante como a cal, para melhorar suas características.

Nessa pesquisa, para as misturas solo-resíduo-cal, Molina (2004) constatou mudanças nos parâmetros de compactação similares às misturas solo-cal, com diminuição na massa específica seca máxima e aumento na umidade ótima. Observou-se também, o aumento contínuo das resistências mecânicas com o aumento no tempo de cura, decorrentes das reações pozolânicas da cal e do resíduo com o solo, desenvolvidas ao longo do tempo. Quanto à adição do resíduo, observou-se um aumento da expansão das misturas, entretanto, os valores de expansão mantiveram-se inferiores aos limites permitidos para a utilização das misturas para camadas de base. 
Machado et al. (2004) estudaram a aplicação da lama-de-calcário como aditivo químico para melhorar as características geotécnicas dos solos, como uma solução tecnológica alternativa de baixo custo para rodovias florestais. Nesse estudo, verificou-se o desempenho geotécnico das misturas com solo e lama-de-calcário para construção rodoviária, analisando parâmetros como CBR, limites de consistência e testes de permeabilidade. O estudo demonstrou o excelente potencial da lama-de-calcário como estabilizante químico com um teor máximo de $25 \%$.

\subsection{ESTABILIZAÇÃO COM CAL}

Os materiais usados na pavimentação rodoviária devem possuir características apropriadas, mas, geralmente os solos existentes no local da construção rodoviária não satisfazem às especificações exigidas para sua utilização. Nesta situação, duas alternativas são esperadas: substituir o material por outro ou corrigi-los, por meio de alguma forma de estabilização, de modo a conferir-Ihes as características necessárias. Entre as formas de estabilização, o uso da cal é uma forma de estabilização química que cresce progressivamente em muitos países.

A cal hidratada comercial quando misturada com o solo úmido, é responsável por vários tipos de reações que modificam suas características. As reações mais importantes das misturas solo-cal são enquadradas em três categorias: permuta iônica e floculação, ação de cimentação (reação pozolânica) e carbonatação.

- A permuta iônica consiste nas reações ocorridas com cátion de cálcio $\left(\mathrm{Ca}^{2+}\right)$ pertencentes na cal que substituem os íons mais fracos, tais como sódio $\left(\mathrm{Na}^{+}\right)$e hidrogênio $\left(\mathrm{H}^{+}\right)$na superfície das partículas de argila (HERRIN \& MITCHELL, 1967). Em condição preferencial de adsorção a permuta iônica obedece à ordem: $\mathrm{Na}^{+}<\mathrm{K}^{+}<\mathrm{Ca}^{++}<\mathrm{Mg}^{++}$, onde os cátions monovalentes são substituídos 
pelos cátions bivalentes. O acúmulo adicional de cátions de cálcio da cal nas partículas de argila devido à preponderância deles sobre os íons monovalentes é responsável pela atração entre as partículas de argila. Essa atração faz com que estas partículas se aglomerem, origina-se assim a floculação. Nesta fase de reações da mistura solo-cal produz-se uma imediata melhora na plasticidade e na trabalhabilidade do solo (TRB, 1987).

- A reação pozolânica consiste na formação de vários compostos cimentantes a partir das reações entre cal, água, sílica e alumina do solo. A adição de cal em teores significativos produz uma elevação no $\mathrm{pH}$ do solo, o que aumenta a solubilidade da sílica e alumina, facilitando assim a combinação com os cátions de cálcio $\left(\mathrm{Ca}_{++}\right)$para formação dos novos compostos cimentantes (TRB, 1987). A reação pozolânica é uma reação lenta, e sua velocidade é em grande parte influenciada pelos tipos de argilo-minerais presente no solo e pelas condições climáticas. Complementarmente, a mistura solo-cal deve ser bem compactada, caso contrário, a cimentação não se processará (HERRIN \& MITCHELL, 1967).

- A carbonatação é o retorno da cal hidratada ao carbonato de cálcio, na qual ocorre com a presença de $\mathrm{CO}_{2}$. A cal reage com o dióxido de carbono do ar atmosférico para formar agentes cimentantes que além de serem mais fracos (LIMA, 1981), eles detêm a ação pozolânica e impendem o ganho normal de resistência mecânica (HERRIN \& MITCHELL, 1967). A carbonatação é uma reação química prejudicial, que deveria ser evitada por procedimentos de construção, adequadamente acelerados e seqüenciados (TRB, 1987).

\subsubsection{Efeito da cal sobre as misturas}

As modificações dos solos pela ação da cal conferem às misturas solo-cal características próprias. De modo geral, a cal afeta de forma favorável as propriedades 
físicas dos solos. Segundo Lima (1981), a adição de cal promove alterações no comportamento dos solos, provenientes de dois tipos distintos de ação da cal.

- Uma ação imediata (minutos de contato) que promove a redução da plasticidade, expansão e alteração nas condições de compactação. Existe também, um aumento do tamanho das partículas da mistura ocasionada pelo fenômeno de troca iônica e floculação, o que torna esse material mais "granular".

- Uma ação em longo prazo caracterizada pela reação pozolânica, que formam produtos cimentantes, com o decorrer do tempo, proporcionando um aumento de resistência e durabilidade.

Em geral, as características de compactação de misturas solo-cal apresentam diferenças com relação ao solo original. Essas diferenças implicam em misturas com uma menor densidade seca máxima e um maior teor de umidade ótimo que a do solo não tratado (CASTRO \& LUİS 1974; TRB, 1987). Normalmente, nas misturas solo-cal, a densidade seca máxima diminuiu com o aumento do teor de cal, enquanto o teor de umidade ótimo aumenta com o aumento do teor de cal (TRB, 1987). Isto não acontece sempre, pois há o conhecimento de misturas que não apresentam estas características, segundo El-rawi \& Awad (1981). O aumento no teor de umidade deve-se à reação pozolânica e à diminuição à troca catiônica. Portanto, o balanceamento entre os dois efeitos pode resultar em pouca ou nenhuma mudança do teor de umidade ótimo e, conseqüentemente, pouca ou nenhuma mudança da massa específica seca máxima (MOLINA, 2004).

Diferentes tipos de ensaios são normalmente usados para acompanhar as mudanças nas propriedades mecânicas das misturas solo-cal, entre estes, o ensaio de resistência à compressão simples é o procedimento mais utilizado para a avaliação das propriedades de engenharia da mistura solo-cal (LIMA, 1981). O ensaio de índice de suporte Califórnia - ISC (CBR - Califórnia Bearing Ratio) é utilizado com menos freqüência, e segundo Ahlberg e Barenberg (1965), este índice não oferece, em geral, valores que possam ser utilizados para 
fins de comparação com outros materiais, devido às elevadas resistências das misturas estabilizadas com cal, passíveis de se desenvolverem pelas reações pozolânicas com o decorrer do tempo. Os ensaios de tração de misturas solo-cal são ensaios dos quais existe pouca informação disponível, e um esforço adicional é necessário para avaliar as características de tração de materiais tratados com cal (TRB, 1987).

Deve ser enfatizado que as propriedades mecânicas das misturas solo-cal são dependentes de muitas variáveis. Entre os principais fatores estão o teor e tipo de cal, tipo de solo, condições de tempo e temperatura de cura, e as interações entre estes fatores influenciam ainda mais a resistência das misturas com cal (TRB, 1987).

Em geral, com relação ao tempo de cura das misturas solo-cal, ocorre um aumento rápido na resistência no princípio da cura, mas à medida que o tempo de cura progride, a taxa de aumento de resistência torna-se cada vez menor (HERRIN \& MITCHELL, 1961). A resistência das misturas aumenta com o tempo de cura, por força das reações físicoquímicas que nelas ocorrem, e as reações pozolânicas, mesmo sendo lentas, fazem com que a resistência, ainda que muito lentamente, aumente após alguns anos (GUIMARÃES, 1971). Estudos mostram que algumas misturas solo-cal têm sua resistência aumentada por um período de 10 anos ou mais (TRB, 1987).

O aumento na resistência das misturas solo-cal é influenciado em grande parte pelo teor e tipo de pozolanas, e logo, pelo tipo de argilo-mineral presente no solo. Portanto, se for apresentada pequena ou nenhuma quantidade de pozolana no solo, a resistência da mistura apresentará apenas uma pequena melhora em comparação à resistência do solo natural. Em geral, solos argilosos são mais reativos e produzem maiores resistências quando estabilizados com cal. No entanto, materiais tais como solos siltosos, arenosos e arenoargilosos têm apresentado melhoras nas suas resistências quando estabilizados com cal (HERRIN \& MITCHELL, 1961). 
Segundo Thompson (1969), os solos são qualificados como reativos quando produzem acréscimos na resistência superiores a $345 \mathrm{kPa}$, após os 28 dias de cura. Aqueles que apresentam ganho de resistência menor, são qualificados como não reativos.

Para as misturas solo-cal, o ganho de resistência ao longo do tempo tem uma influência marcante da temperatura, um fator importante, que contribui para sua utilização com sucesso em regiões de clima quente (LIMA, 1981).

Para se verificar a influência da cal nas características do solo, alguns trabalhos foram utilizados no intuito de se estabelecer valores que sirvam como parâmetros de referência para os dados obtidos neste trabalho. Castro \& Luís (1974) verificaram a influência da cal na massa específica seca máxima e na umidade. TRB (1987) verificou à influência da cal em função do tempo e temperatura de cura. Basma \& Tuncer (1991) verificaram à influência da cal nas mudanças de volume. Mateos (1964) verificou à influência da cal no módulo de resiliência. Mendonça et al. (1997) verificaram à influência da cal em função da imersão em água e tempo de cura. Filho et al. (2001) verificaram à influência da cal nos limites de consistências. Lovato et al. e Molina (2004) verificaram à influência da cal na resistência à tração e compressão. Estes importantes trabalhos e outros que se dedicam à estabilização com cal, foram utilizados para facilitar a comparação e avaliação de resultados, buscando assim maior credibilidade nas análises deste trabalho.

\subsubsection{Materiais calcários estabilizados com cal}

A utilização de cal hidratada para a melhoria no comportamento mecânico de materiais calcários tem sido realizada com sucesso em alguns estudos (GRAVES, 1987; BHUIYAN et al., 1995; MOLINA, 2004). 
O acréscimo de hidróxido de cálcio aumenta a quantidade de carbonatos cimentados, aumentando conseqüentemente, a resistência desenvolvida, pois a cal hidratada é uma fonte adicional de íons de cálcio, o que aumenta os efeitos de cimentação (GRAVES, 1987).

Segundo Bhuiyan et al. (1995), materiais calcários estabilizados com cal apresentam aumentos significativos de resistência quando comparados com materiais calcários não estabilizados. Esta melhora na resistência deve-se à formação de carbonatos de cálcio, induzida pelo acréscimo de cal hidratada.

Misturas de materiais calcários estabilizados com cal apresentam maiores ganhos de resistência quanto maiores são as concentrações de calcita $\left(\mathrm{CaCO}_{3}\right)$ (GRAVES, 1987; BHUIYAN et al., 1995). 


\section{MATERIAIS E MÉTODOS}

\subsection{INTRODUÇÃO}

Neste capítulo são apresentados os materiais utilizados na pesquisa, o local da coleta do resíduo e solos que compõem as misturas estabilizadas com cal. Ainda são descritos os equipamentos e procedimentos laboratoriais que foram empregados para execução dos ensaios de compressão simples, compressão diametral e triaxial cíclico, destacando os resultados dos ensaios de caracterização, classificação geotécnica e análise química dos materiais. Finalmente, apresenta-se a metodologia empregada para a aceitação dos resultados obtidos.

\subsection{COLETA E CARACTERÍSTICAS DOS MATERIAIS UTILIZADOS}

\subsubsection{Resíduo da pasta de celulose}

O resíduo da produção de pasta de celulose estudado consiste em uma mistura de calcário e dregs (conforme definidos no Item 2.3). O material foi coletado em uma das 
indústrias da International Paper do Brasil, localizada no interior paulista, na cidade de Mogi Guaçu. Na sua condição natural, o resíduo teve um teor de umidade aproximado de $70 \%$.

O material coletado foi acondicionado em sacos plásticos e transportado até o Laboratório de Estradas do Departamento de Transportes da EESC-USP, em São Carlos (SP). A amostra foi peneirada na peneira $\mathrm{N}^{\circ} 4$ e seca ao ar até alcançar teores de umidade inferiores a $20 \%$. Depois da secagem, a amostra foi homogeneizada por quarteamento. Em seguida, $250 \mathrm{~kg}$ do material foram embalados em sacos plásticos e estocados para a realização da pesquisa. A Figura 3.1 apresenta o resíduo ao final do processo de secagem e homogeneização, apresentando uma cor cinza claro, sem odor particular, homogêneo e de grãos finos.

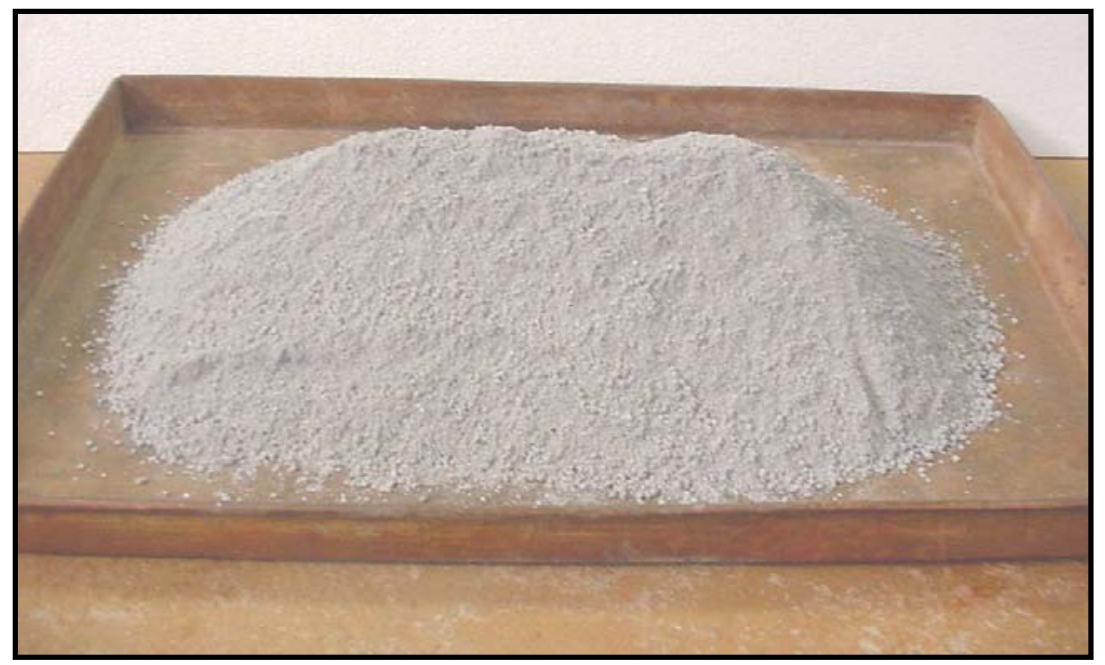

Figura 3.1 - Lama de calcário e dregs após secagem e homogeneização

\subsubsection{Solos}

Os três solos analisados nesta pesquisa foram coletados de diferentes regiões do interior paulista. O critério para escolha dos solos 1 e 2 utilizados nesta pesquisa foi de que ambos deveriam pertencer a uma mesma classe, segundo as classificações tradicionais, HRB (ASSHTO - M145) e Unificada (ASTM - D2487), e deveriam apresentar quanto à 
gênese, comportamentos laterítico e não laterítico, respectivamente, segundo a classificação MCT (DNER-CLA259-96). O solo 3 foi escolhido numa região onde se localiza a indústria de papel, na tentativa de uma possível aplicação da mistura de solo e resíduo, nas áreas pertencentes à indústria.

Os solos 1 e 2 foram coletados, respectivamente, próximo à cidade de Itápolis/SP, às margens da rodovia SP-304 num talude, acima da linha de seixos e próximo à cidade de Bauru/SP, às margens da rodovia SP-294 num talude, abaixo da linha de seixos. O local de coleta do solo 3 se encontra na região de Mogi Guaçu, onde se localiza a indústria de papel. A Figura 3.2 ilustra os locais de coleta dos solos.

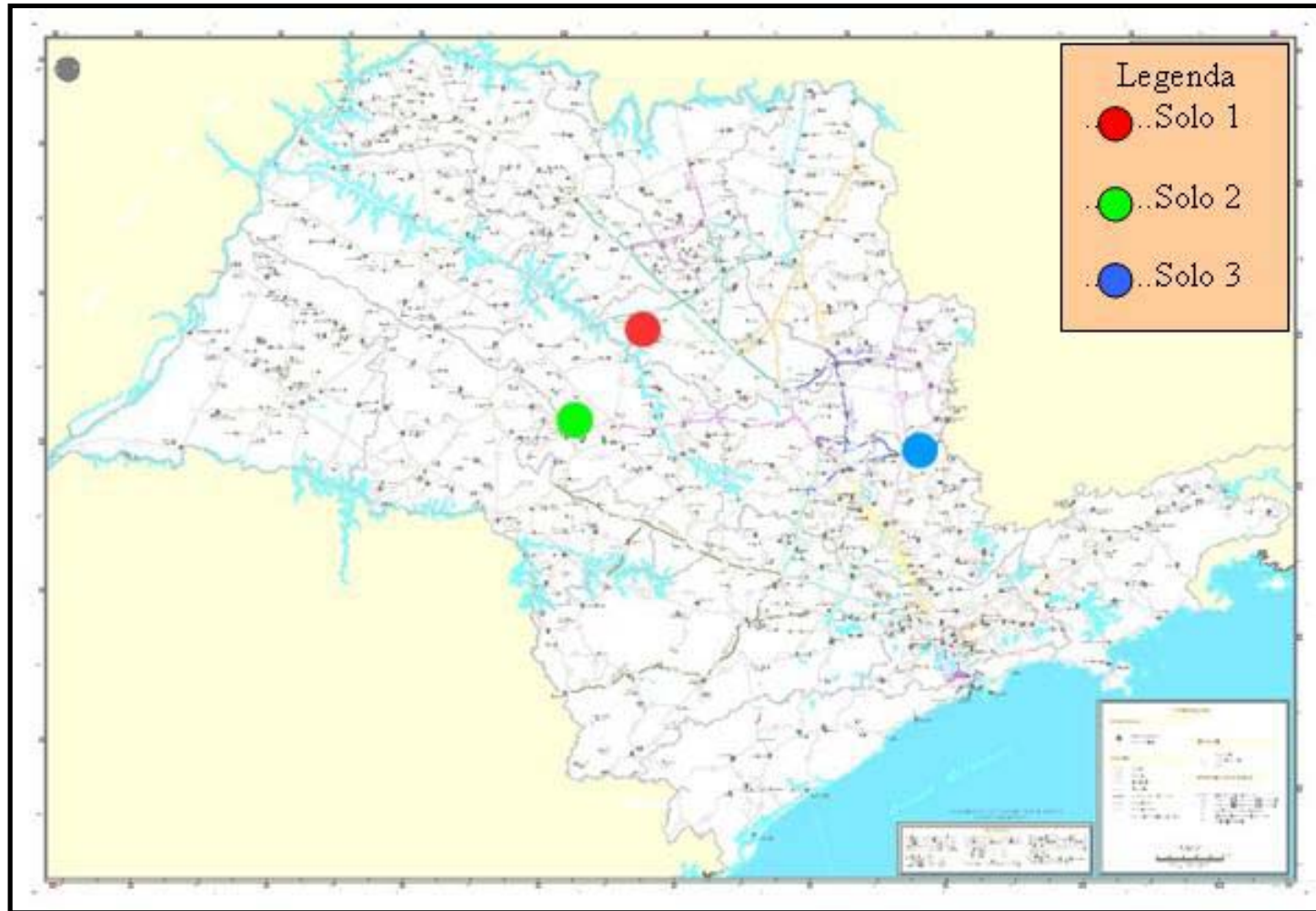

Figura 3.2 - Indicação aproximada dos locais de coleta das amostras 


\subsection{CARACTERIZAÇÃO E CLASSIFICAÇÃO DOS MATERIAIS}

\subsubsection{Caracterização dos materiais}

Considera-se como caracterização a determinação da massa específica dos sólidos, a análise granulométrica conjunta (peneiramento e sedimentação) e a determinação dos limites de consistência. A análise granulométrica do solo foi realizada de acordo com o método de ensaio "Solo - Análise Granulométrica", NBR 7181 (ABNT, 1984). Para a fração grossa (partículas com diâmetro maior ou igual a $0,074 \mathrm{~mm}$ ) realizou-se o processo de peneiramento e para a fração fina (partículas com diâmetro inferior a 0,074 mm) o de sedimentação. As Figuras 3.3 e 3.4 apresentam, respectivamente, as curvas granulométricas correspondentes ao resíduo e aos solos estudados.

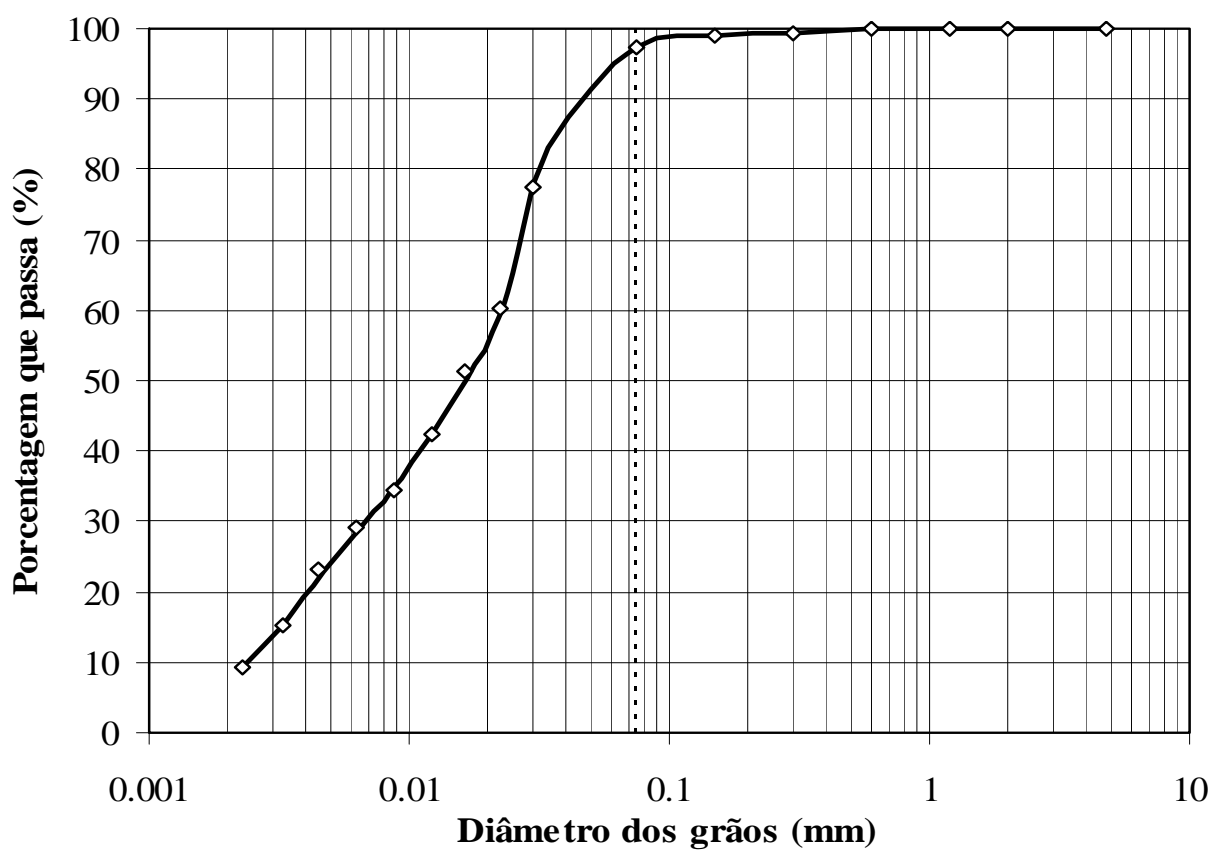

Figura 3.3 - Curva granulométrica do resíduo de pasta de celulose

A granulometria do resíduo de pasta de celulose corresponde à de um silte, com $97,50 \%$ passando na peneira $N^{\circ} 200$. Segundo a classificação Unificada, o material é classificado como um silte de baixa compressibilidade (ML). 


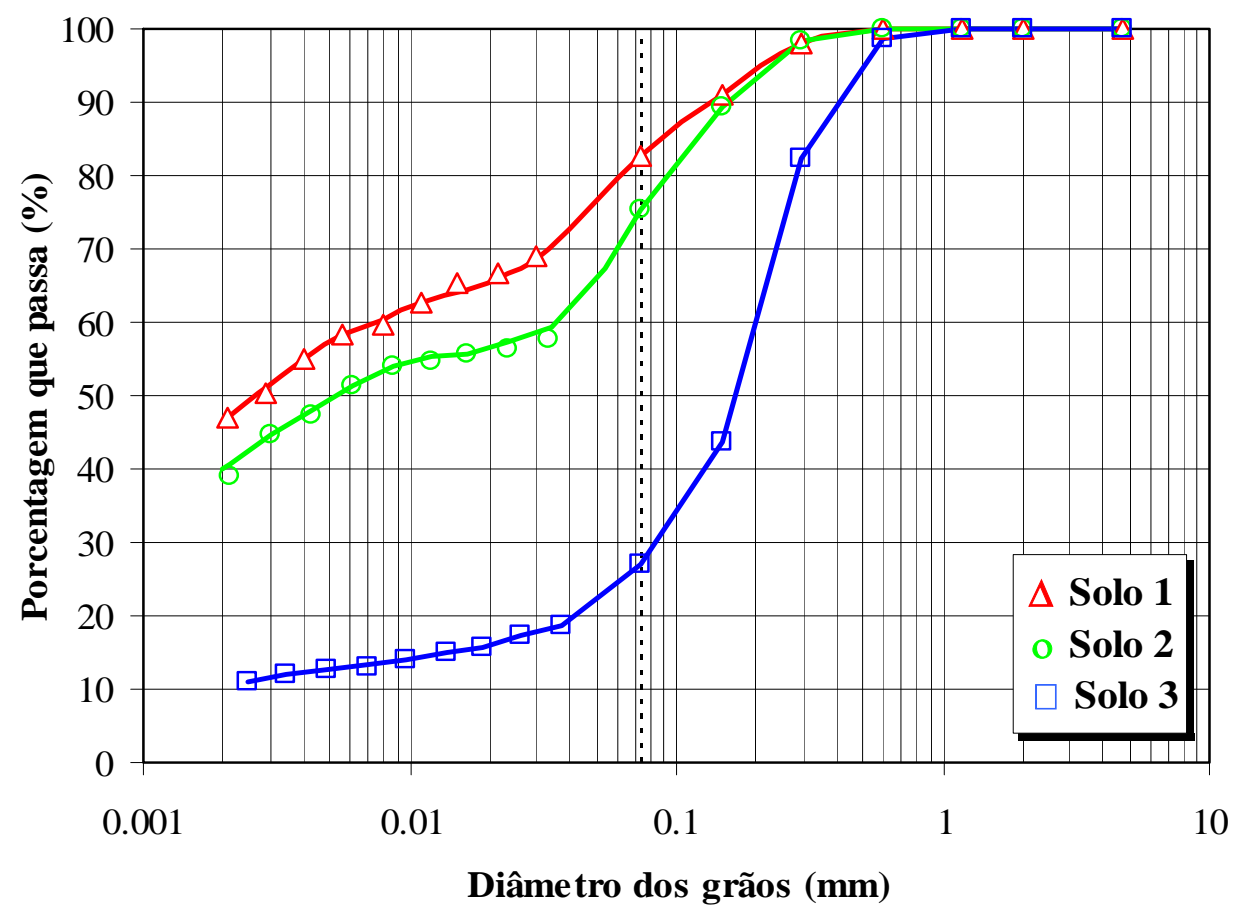

Figura 3.4 - Curva granulométrica dos solos

A determinação da massa específica dos sólidos foi realizada segundo a norma da ABNT NBR 6508. Posteriormente, foi realizada a determinação do limite de liquidez, segundo a norma da ABNT NBR 6459 e o de plasticidade, segundo a norma da ABNT NBR 7180. Os resultados estão apresentados na Tabela 3.1.

Tabela 3.1 - Massa específica, LL, LP e IP dos sólidos do resíduo e dos solos

\begin{tabular}{lcccc}
\hline Material & $\begin{array}{c}\text { Massa específica dos } \\
\text { sólidos }\left(\mathbf{g} / \mathbf{c m}^{\mathbf{3}}\right)\end{array}$ & LL (\%) & LP (\%) & IP (\%) \\
\hline Resíduo & 2,841 & & NP & \\
Solo 1 & 2,974 & 49 & 30 & 19 \\
Solo 2 & 2,724 & 59 & 35 & 24 \\
Solo 3 & 2,602 & & NP & \\
\hline
\end{tabular}

Para a determinação do limite de liquidez do resíduo da pasta de celulose, o ensaio foi considerado inexeqüível devido ao material não apresentar a trabalhabilidade necessária para sua execução. Nos ensaios de limite de plasticidade do resíduo de pasta de celulose e do solo 3 não foi possível à formação dos cilindros, levando a classificá-los como materiais não plásticos (NP). 


\subsubsection{Classificação dos solos}

Os resultados dos ensaios de caracterização possibilitaram as classificações dos solos segundo a USCS (Unified Soil Classification System) e HRB (Highway Research Board). Complementarmente, foram realizados os ensaios necessários para a classificação segundo a metodologia MCT (Miniatura, Compactação, Tropical). A Tabela 3.2 apresenta os resultados dos ensaios de caracterização dos solos preconizados na norma ASTM - D2487 e AASHTO - M145, respectivamente para as classificações USCS e HRB.

Tabela 3.2 - Classificações USCS e HRB dos solos

\begin{tabular}{lcc}
\hline Material & USCS & HRB \\
\hline Solo 1 & ML & A-7-5 \\
Solo 2 & MH & A-7-5 \\
Solo 3 & SM & A-2-4 \\
\hline
\end{tabular}

A Tabela 3.3 apresenta o resultado do ensaio e os valores do coeficiente c', do índice e' e dos parâmetros d' e Pi obtidos a partir dos ensaios descritos segundo a norma DNERCLA259-96 para a metodologia MCT.

Tabela 3.3 - Resultados dos ensaios da metodologia MCT

\begin{tabular}{lccccc}
\hline Material & c' $^{\prime}$ & d' $^{\prime}$ & $\mathbf{P i}$ & $\mathbf{e}^{\prime}$ & MCT \\
\hline Solo 1 & 1,86 & 46,50 & 40 & 0,94 & LG' $^{\prime}$ \\
Solo 2 & 1,90 & 25,00 & 175 & 1,37 & NG' \\
Solo 3 & 0,75 & 48,71 & 102 & 1,13 & LA' $^{\prime}$ \\
\hline
\end{tabular}

Assim, a partir dos ensaios realizados segundo a metodologia MCT (NOGAMI \& VILLIBOR, 1995), foi possível determinar a posição ocupada pelos solos estudados no ábaco de classificação, conforme ilustrado na Figura 3.5. 


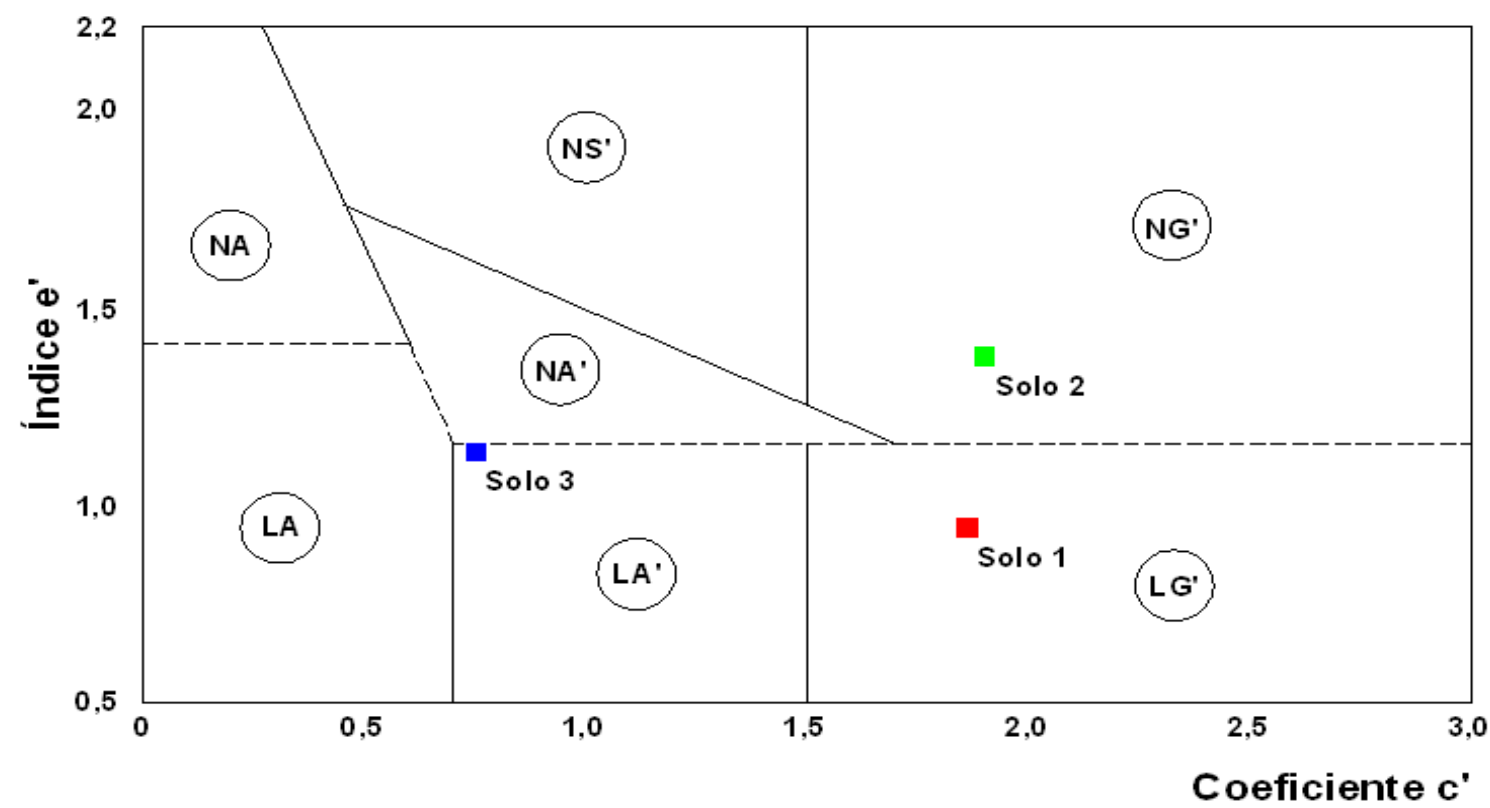

Figura 3.5 - Localização dos pontos representativos dos solos

Dentre os solos estudados, apenas o solo 3 se encontra próximo dos limites entre as classes L (comportamento laterítico) e N (comportamento não-laterítico). Para determinar o comportamento desse solo foi traçado a curva de Mini-MCV em função do teor de umidade de compactação, onde a curva apresentou uma concavidade voltada para cima, o que constata um comportamento laterítico, conforme ilustrado na Figura 3.6. Se o gráfico apresentasse uma curva com concavidade voltada para baixo, o solo deveria ser considerado de comportamento não-laterítico.

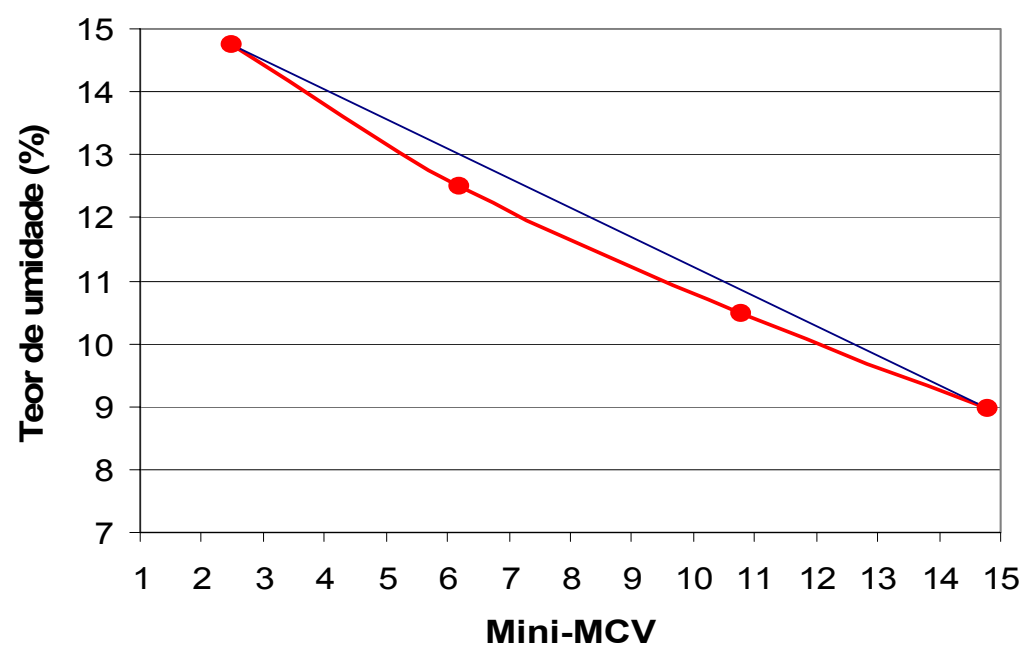

Figura 3.6 - Curva Mini-MCV x teor de umidade 
Nas análises, o Solo 1 (ML, A-7-5, LG'), o Solo 2 (MH, A-7-5, NG') e o Solo 3 (SM, A2-4, LA'), serão denominados, respectivamente, 'solo argiloso laterítico', 'solo argiloso nãolaterítico' e 'solo arenoso laterítico'.

\subsubsection{Cal}

Para os experimentos realizados nesta pesquisa foi utilizada a cal hidratada cálcica, da marca Supercal, do tipo $\mathrm{CH}-\mathrm{III}$, segundo a norma ABNT NBR 7175. A Tabela 3.4 apresenta a composição química da cal empregada neste trabalho, conforme resultados fornecidos pelo fabricante Ical - Indústria de Calcinação Ltda.

Tabela 3.4 - Composição química e física da cal utilizada

\begin{tabular}{|c|c|}
\hline Componentes & Teor (\%) \\
\hline $\mathrm{SiO}_{2}$ & 2,60 \\
\hline $\mathrm{Al}_{2} \mathrm{O}_{3}$ & 0,57 \\
\hline $\mathrm{Fe}_{2} \mathrm{O}_{3}$ & 0,20 \\
\hline $\mathrm{CaO}_{\text {(tot) }}$ & 70,10 \\
\hline $\mathrm{MgO}$ & 0,56 \\
\hline $\mathrm{SO}_{3}$ & 0,81 \\
\hline Perda ao fogo & 25,51 \\
\hline Umidade & 0,49 \\
\hline $\mathrm{CO}_{2}$ & 9,86 \\
\hline$P_{32} \quad 0,600 \mathrm{~mm}$ & 0,12 \\
\hline$P_{200} \quad 0,075 \mathrm{~mm}$ & 8,75 \\
\hline $\mathrm{CaO}_{(\mathrm{N} / \mathrm{H})}$ & 9,26 \\
\hline Óxidos $(N / H)$ & 9,82 \\
\hline $\mathrm{C}+\mathrm{M}_{\text {(óxidos totais) }}$ & 94,86 \\
\hline
\end{tabular}

Fonte: Boletim de análise da cal (Ical, 2005)

Segundo a norma ABNT NBR 7175, é estabelecido que a cal hidratada $\mathrm{CH}-\mathrm{III}$ deve apresentar limites de anidrido carbônico $\left(\mathrm{CO}_{2}\right)$ inferiores a $15 \%$, de óxidos totais na base de não-voláteis $\left(C+M_{\text {(óxidos totais) })}\right)$ superiores a $80 \%$, de óxidos não-hidratados inferiores a 15\%, porcentagem retida acumulada inferiores a $0,5 \%$ na peneira de $0,600 \mathrm{~mm}$ e de $15 \%$ na 
peneira de $0,075 \mathrm{~mm}$. Todas essas exigências acima citadas são respeitadas pela cal utilizada neste trabalho.

\subsection{COMPOSIÇÃO DAS MISTURAS E ENSAIOS DE COMPACTAÇÃO}

Com o propósito de avaliar e comparar o desempenho da adição da cal e do resíduo foram realizados ensaios para a determinação do comportamento mecânico nos solos naturais e nas misturas de solo-cal e solo-resíduo-cal.

A composição das misturas de solo-cal foi determinada com base em ensaios preliminares de compressão simples, sem imersão em água. Obtiveram-se as resistências das misturas de solo argiloso laterítico (LG') e solo argiloso não-laterítico (NG') com 0\%, 3\%, $5 \%, 7 \%$ e $10 \%$ de cal, teores estes escolhidos por serem de uso comum nos estudos de misturas solo-cal. Segundo a State of the art 5 - Lime stabilization (TRB, 1987) as misturas de solo estatabilizadas com cal podem ser compactadas segundo as normas AASHTO T-99 ou T-180, correspondentes, respectivamente às energias normal e modificada do ensaio de Proctor, dependendo do órgão ou estado Norte-americano. Nesta pesquisa, adotou-se a energia normal segundo preconizado no Ilinois Procedure.

A partir dos resultados obtidos desta análise preliminar, foram escolhidos os teores de $5 \%$ e $10 \%$ de cal para as composições das misturas solo-cal e solo-resíduo-cal. O teor de $5 \%$ foi selecionado tendo em vista que as misturas de solo-cal com o teor de $3 \%$ apresentaram baixas resistências em comparação com os solos sem adição de cal. Adotouse também o teor de $10 \%$ de cal, para dar continuidade ao estudo de Molina (2004), que constatou o melhor comportamento de misturas solo-resíduo-cal para este teor. Apesar de ser um teor elevado para a aplicação de misturas solo-cal, este teor possibilitará a comparação do desempenho do comportamento mecânico das misturas envolvidas. 
Posteriormente, foram realizados ensaios de compactação de misturas solo-resíduo para determinar o teor máximo de resíduo que seria utilizado nas misturas. Foram considerados teores de $40 \%, 45 \%$ e $50 \%$ de resíduo para as misturas com o solo argiloso laterítico (LG') e argiloso não-laterítico (NG'). Os ensaios de compactação da mistura soloresíduo foram realizados na energia equilavente ao Proctor Normal, seguindo a norma ABNT NBR 7182. O teor estabelecido de resíduo para a composição das misturas foi de $40 \%$, valor máximo alcançado de resíduo sem que a trabalhabilidade das misturas interferisse nos resultados do ensaio de compactação. A partir de 40\%, o resíduo aumenta a plasticidade da mistura de tal forma, que à medida que o ensaio de compactação é executado, a mistura adere ao soquete de compactação, interferindo na energia de compactação e conseqüentemente no resultado do ensaio. Este mesmo fato foi observado por Molina (2004).

Com base nos estudos preliminares, as Tabelas 3.5, 3.6 e 3.7 apresentam as composições escolhidas para a avaliação do comportamento mecânico das misturas.

Tabela 3.5 - Misturas ensaiadas para o solo argiloso laterítico (LG')

\begin{tabular}{lccc}
\hline Misturas & Solo (\%) & Resíduo (\%) & Cal (\%) \\
\hline Mistura 1 & 100 & 0 & 0 \\
Mistura 2 & 95 & 0 & 5 \\
Mistura 3 & 90 & 0 & 10 \\
Mistura 4 & 60 & 40 & 0 \\
Mistura 5 & 55 & 40 & 5 \\
Mistura 6 & 50 & 40 & 10 \\
\hline
\end{tabular}

Tabela 3.6 - Misturas ensaiadas para o solo argiloso não-laterítico (NG')

\begin{tabular}{lccc}
\hline \multicolumn{1}{c}{ Misturas } & Solo (\%) & Resíduo (\%) & Cal (\%) \\
\hline Mistura 7 & 100 & 0 & 0 \\
Mistura 8 & 95 & 0 & 5 \\
Mistura 9 & 90 & 0 & 10 \\
Mistura 10 & 60 & 40 & 0 \\
Mistura 11 & 55 & 40 & 5 \\
Mistura 12 & 50 & 40 & 10 \\
\hline
\end{tabular}


Tabela 3.7 - Misturas ensaiadas para o solo arenoso laterítico (LA')

\begin{tabular}{lccc}
\hline \multicolumn{1}{c}{ Misturas } & Solo (\%) & Resíduo (\%) & Cal (\%) \\
\hline Mistura 13 & 60 & 40 & 0 \\
Mistura 14 & 55 & 40 & 5 \\
Mistura 15 & 50 & 40 & 10 \\
\hline
\end{tabular}

O ensaio de compactação teve como objetivo determinar os valores de massa específica seca máxima ( $\left.\rho_{\text {dmáx }}\right)$ e umidade ótima $\left(\omega_{0}\right)$ das misturas escolhidas.

\subsection{PROPRIEDADES MECÂNICAS DAS MISTURAS}

A determinação das propriedades mecânicas das misturas baseou-se nos resultados de ensaios de compressão simples, tração indireta e triaxial cíclico. Para os ensaios de compressão simples e tração indireta os corpos-de-prova foram submetidos a duas condições de ensaio: sem imersão e após imersão prévia em água por um período de 4 horas, com o objetivo de avaliar o efeito da água na resistência e rigidez das misturas.

\subsubsection{Ensaio de compressão simples}

\subsubsection{Moldagem dos corpos-de-prova}

Para todas as misturas citadas no Item 3.4 foram realizados ensaios de compressão simples com corpos-de-prova moldados na umidade ótima $\left(\omega_{0}\right)$ e massa específica seca máxima ( $\left.\rho_{\text {dmáx }}\right)$. Os corpos-de-prova foram compactados estaticamente em três camadas, utilizando-se o molde cilíndrico metálico de diâmetro interno de $5,0 \mathrm{~cm}$ e altura de $10,0 \mathrm{~cm}$. 0 molde utilizado possui um conjunto de peças acopláveis formados por um corpo cilíndrico principal, dois anéis complementares e dois êmbolos espaçadores, como apresentado na Figura 3.7. 


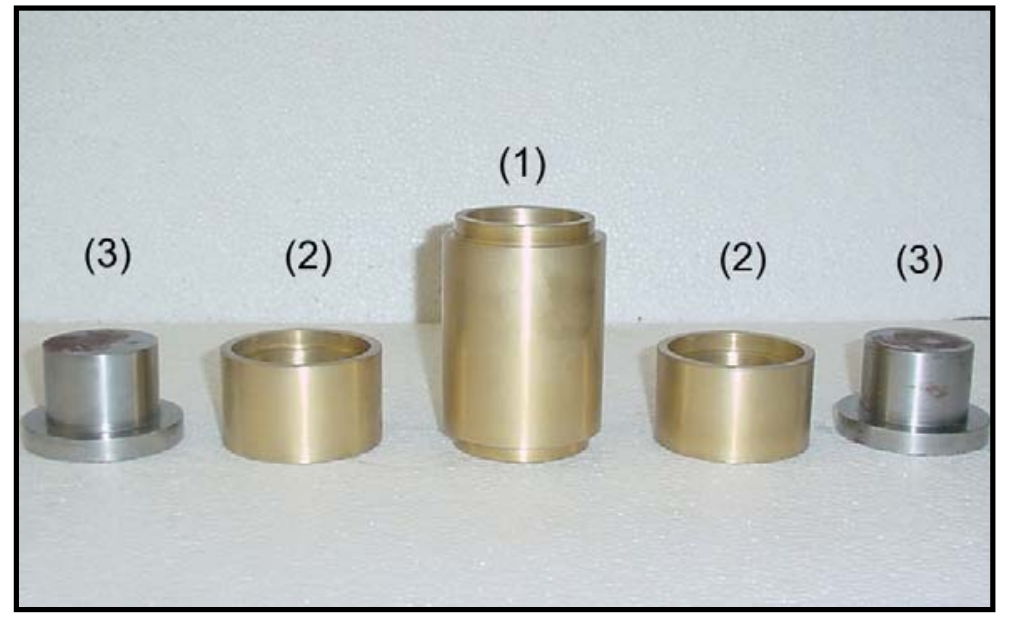

Figura 3.7 - Equipamento para moldagem dos corpos-de-prova de compressão simples: (1) cilindro principal, (2) anéis complementares e (3) êmbolos espaçadores

Para a compactação dos corpos-de-prova foi utilizada a prensa hidráulica do Laboratório de Estradas do Departamento de Transportes da EESC/USP, apresentada na Figura 3.8 .

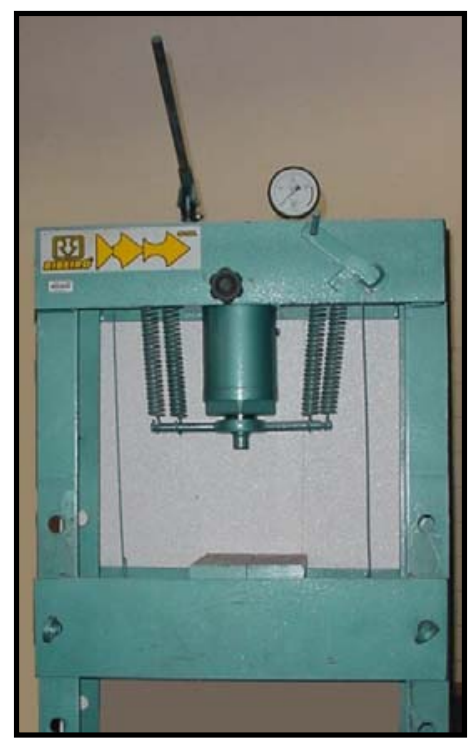

Figura 3.8 - Prensa hidráulica para moldagem 


\subsubsection{Ensaio dos corpos-de-prova}

Para a execução dos ensaios de compressão simples foram moldados 3 corpos-deprova para cada condição de ensaio e composição de mistura. Os ensaios foram realizados utilizando a prensa da marca VERSA TESTER 30M (Figura 3.9) do Laboratório de Estradas do Departamento de Transportes da EESC/USP com uma velocidade de $1,25 \mathrm{~mm} / \mathrm{min}$. As cargas aplicadas nos corpos-de-prova e os deslocamentos ocorridos durante os ensaios foram registrados por uma célula de carga e um LVDT, respectivamente. Os dados foram monitorados e registrados por um programa computacional de aquisição de dados fornecendo um relatório de cada ensaio executado.

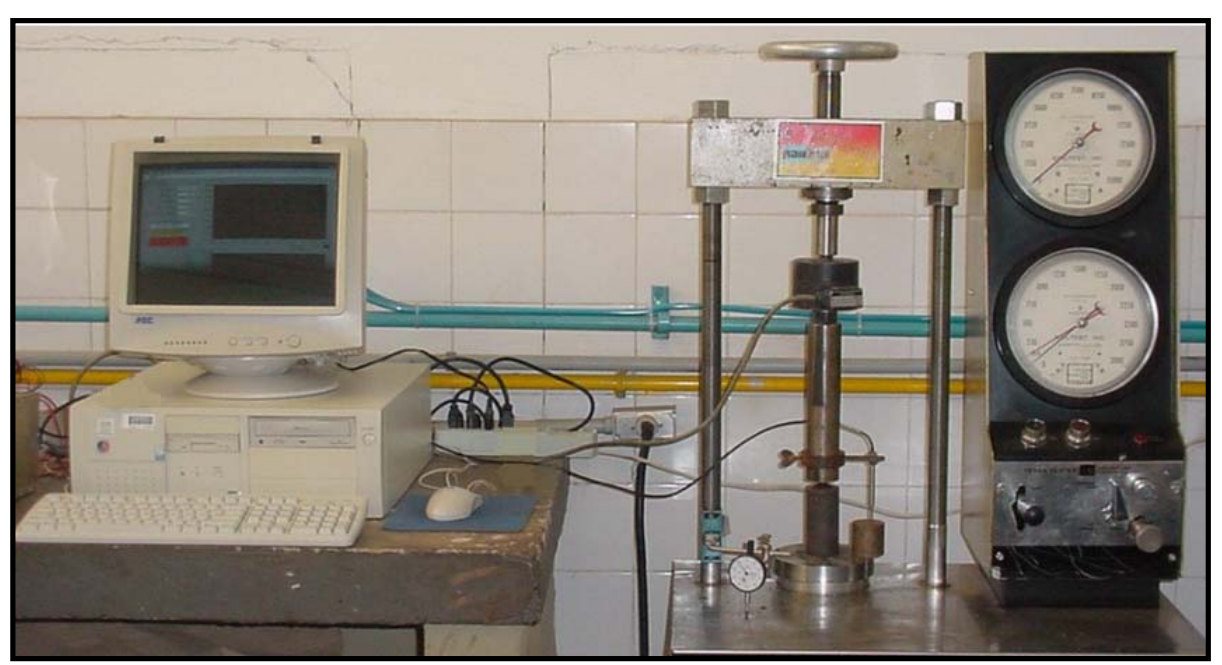

Figura 3.9 - Ruptura dos corpos-de-prova no ensaio de compressão simples

\subsubsection{Determinação da resistência à compressão simples e deformabilidade}

A partir dos valores de tensão e deformação obtidos pelo ensaio de compressão simples, foram determinados a deformabilidade e a resistência à compressão simples (RCS) das misturas estudadas. Podendo-se analisar esses parâmetros quanto à influência da imersão em água, do tempo de cura e dos teores de resíduo e cal. 
O estudo da deformabilidade das misturas de solo-cal e solo-resíduo-cal foi realizado através da análise da variação do módulo tangente inicial $\left(E_{0}\right)$, determinado a partir do procedimento adotado por DUNCAN \& CHANG (1970) que propõe a curva 'tensão versus deformação' resultante do ensaio de compressão simples, cuja expressão é representada na Equação 3.1.

onde:

$$
\frac{\varepsilon_{\mathrm{a}}}{\sigma_{\mathrm{a}}}=\mathrm{a}+\mathrm{b} \varepsilon_{\mathrm{a}}
$$

$\varepsilon_{\mathrm{a}}$ - deformação axial;

$\sigma_{\mathrm{a}}-$ tensão axial $(\mathrm{kPa})$;

$\mathbf{a}$ e $\mathbf{b}$ - coeficientes de regressão.

Dessa forma, os parâmetros a e b da Equação 3.1 são obtidos a partir da reta que melhor se ajusta aos resultados experimentais e o $E_{0}$ é calculado pela Equação 3.2. A Figura 3.10 ilustra a forma de se adquirir o parâmetro a.

$$
E_{0}=\frac{1}{\mathrm{a}}
$$

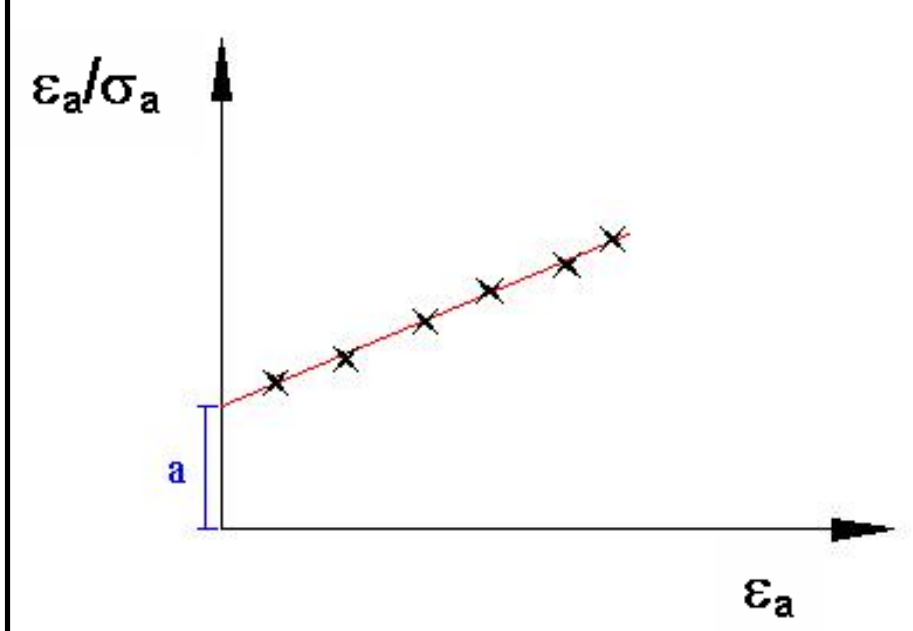

Figura 3.10 - Estimativa de $\mathrm{E}_{0}$ a partir da determinação do coeficiente "a", segundo o modelo hiperbólico proposto por DUNCAN \& CHANG (1970) 


\subsubsection{Ensaios de tração indireta}

\subsubsection{Moldagem dos corpos-de-prova}

Para todas as misturas citadas no Item 3.4 foram realizados ensaios de compressão diametral com corpos-de-prova moldados na umidade ótima $\left(\omega_{0}\right)$ e massa específica seca máxima $\left(\rho_{\mathrm{dmáx}}\right)$. Os corpos-de-prova foram compactados estaticamente em uma camada, utilizando-se um molde cilíndrico metálico e dois êmbolos (Figura 3.11) que resultaram em corpos-de-prova de diâmetro interno de 5,0 cm e altura de 5,0 cm. Para a compactação dos corpos-de-prova foi utilizada a mesma prensa hidráulica utilizada para moldar os corpos-deprova no ensaio de compressão simples.

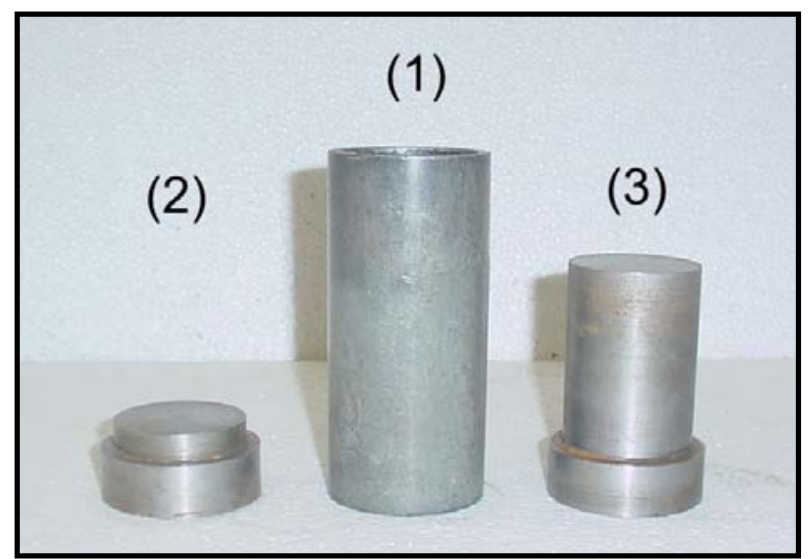

Figura 3.11 - Equipamento para moldagem dos corpos-de-prova de compressão diametral: (1) cilindro principal, (2) êmbolo menor e (3) êmbolo maior

\subsubsection{Ensaio dos corpos-de-prova}

Para a execução dos ensaios de compressão diametral foram moldados 3 corpos-deprova para cada condição de ensaio e mistura. Os ensaios foram realizados utilizando o equipamento ilustrado na Figura 3.12 para determinar a resistência à tração. A velocidade utilizada foi de $1,25 \mathrm{~mm} / \mathrm{min}$, a mesma do ensaio de compressão simples. 


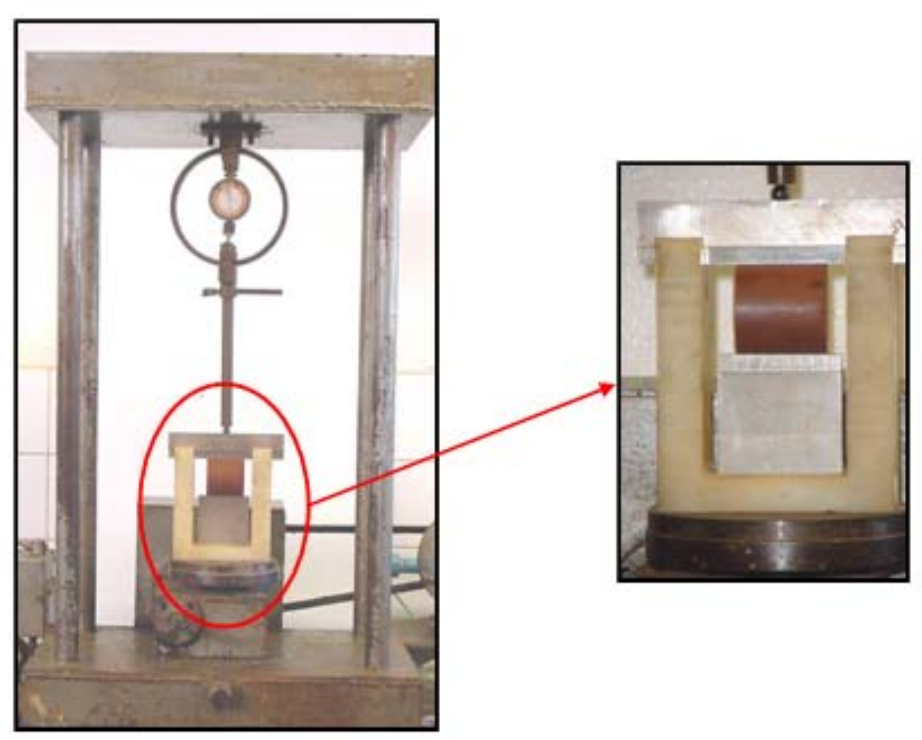

Figura 3.12 - Ruptura dos corpos-de-prova no ensaio de compressão diametral

\subsubsection{Determinação da resistência à compressão diametral}

Os valores das cargas aplicadas nos ensaios de compressão diametral foram utilizados para determinar a resistência à tração das misturas e assim analisar a influência da imersão em água, do tempo de cura e dos teores de resíduo e cal.

Para calcular a tração no centro da amostra é utilizada a Equação 3.3:

Onde:

$$
\sigma_{t}=\frac{2 \cdot F}{\pi \cdot t \cdot d}
$$

$\sigma_{\mathfrak{t}}$ é a resistência à tração $\left(\mathrm{kgf} / \mathrm{cm}^{2}\right)$;

F é a carga diametral aplicada (kgf);

t é a altura do corpo-de-prova $(\mathrm{cm})$;

d é o diâmetro do corpo-de-prova (cm); 


\subsubsection{Ensaios triaxiais cíclicos}

Nos ensaios triaxiais cíclicos, optou-se por ensaiar apenas um corpo-de-prova para cada condição estudada em função da dificuldade na execução dos mesmos. Acredita-se que este procedimento não incorra em problemas de confiabilidade, visto que estes ensaios apresentam boa repetibilidade tanto para ensaios realizados no mesmo corpo-de-prova quanto para ensaios realizados em corpos-de-prova diferentes (PARREIRA ET AL., 1998).

\subsubsection{Moldagem dos corpos-de-prova}

Os corpos-de-prova foram moldados na umidade ótima $\left(\omega_{0}\right)$ e massa específica seca máxima $\left(\rho_{\text {dmáx }}\right)$. O solo foi previamente seco ao ar e adicionada água suficiente para se atingir à umidade desejada, sendo então o material homogeneizado e embalado em saco plástico. Após a homogeneização, duas cápsulas do solo foram retiradas para a verificação do teor de umidade atingido. Os corpos-de-prova foram moldados após vinte quatro horas, período usado para a determinação da umidade e também para a equalização da umidade na amostra. A moldagem era realizada apenas se a umidade atingida pela amostra estivesse dentro de um intervalo de $\pm 0,5 \%$ da umidade alvo.

O processo de moldagem foi realizado estaticamente em três camadas, para corposde-prova de $100 \mathrm{~mm}$ de altura e $50 \mathrm{~mm}$ de diâmetro. Após a moldagem foi determinada a massa e geometria (altura e diâmetro) de cada corpo-de-prova, sendo possível assim, ter feito a estimativa da massa específica úmida e, conseqüentemente, a determinação do grau de compactação. Dessa forma, em função de critérios de aceitação, foi possível decidir sobre o descarte ou não dos corpos-de-prova, sendo o mesmo descartado cujo grau de compactação não estivesse no intervalo de 99\% a 101\%. 


\subsubsection{Ensaio dos corpos-de-prova}

Para a realização dos ensaios triaxiais cíclicos foi usada uma prensa da marca MTS (Material Testing System), modelo 815 (Figura 3.13), pertencente ao Laboratório de Geotecnia da EESC - USP.

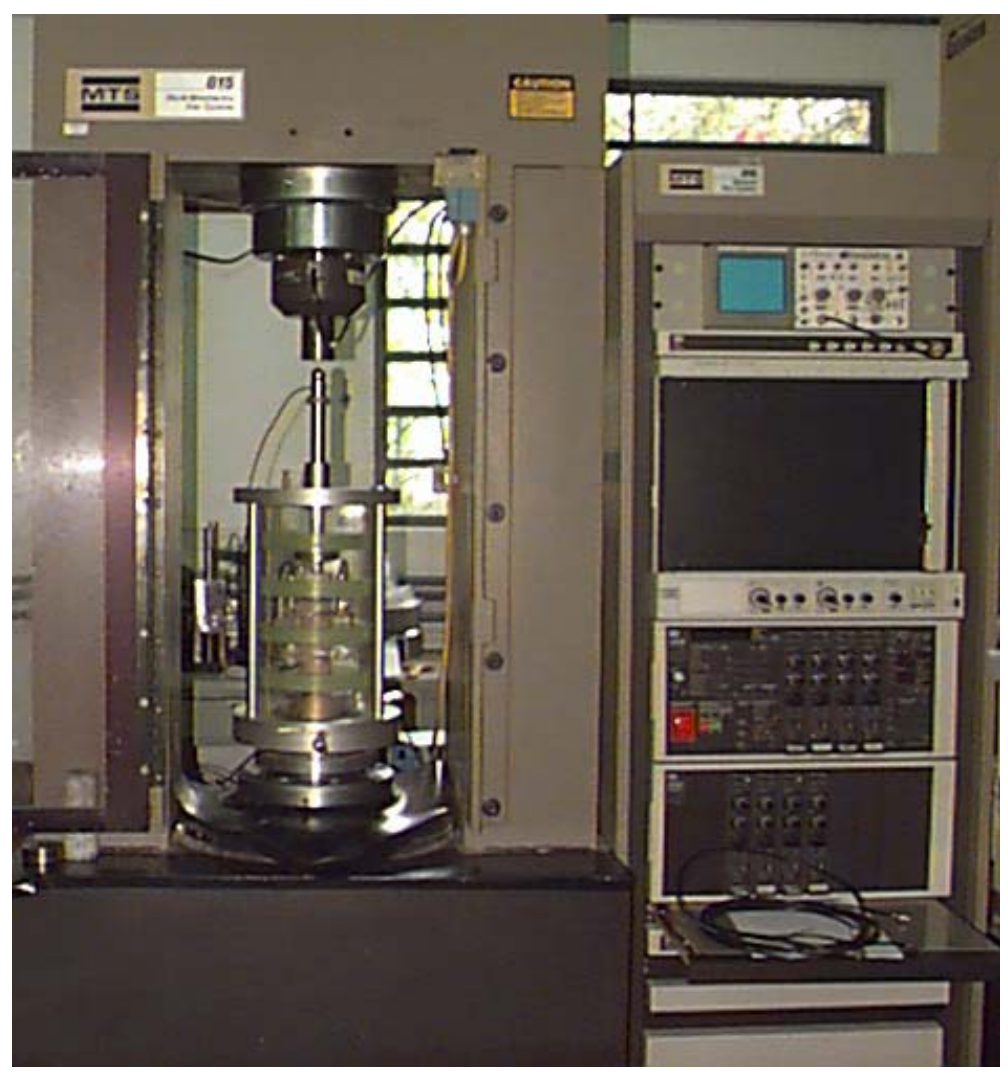

Figura 3.13: Prensa MTS modelo 815

A prensa MTS possui um sistema de carregamento hidráulico que permite, através de um gerador de funções, que se selecione previamente a forma, duração e freqüência de aplicação das cargas. A célula de carga usada nos ensaios é da marca WYKEHAM FARRANCE, com capacidade máxima de carga de $3 \mathrm{kN}$, e posicionada internamente à câmara triaxial. O equipamento permite manter-se uma tensão de contato mínima no corpode-prova, estabelecida em $10 \%$ da tensão máxima. O fluido usado para confinamento dos corpos-de-prova no interior da câmara triaxial é o ar, sendo o controle de aplicação realizado 
de forma manual. A medida dos deslocamentos é feita com o auxílio de dois LVDTs, instalados nos terços médios dos corpos-de-prova (Figura 3.14).

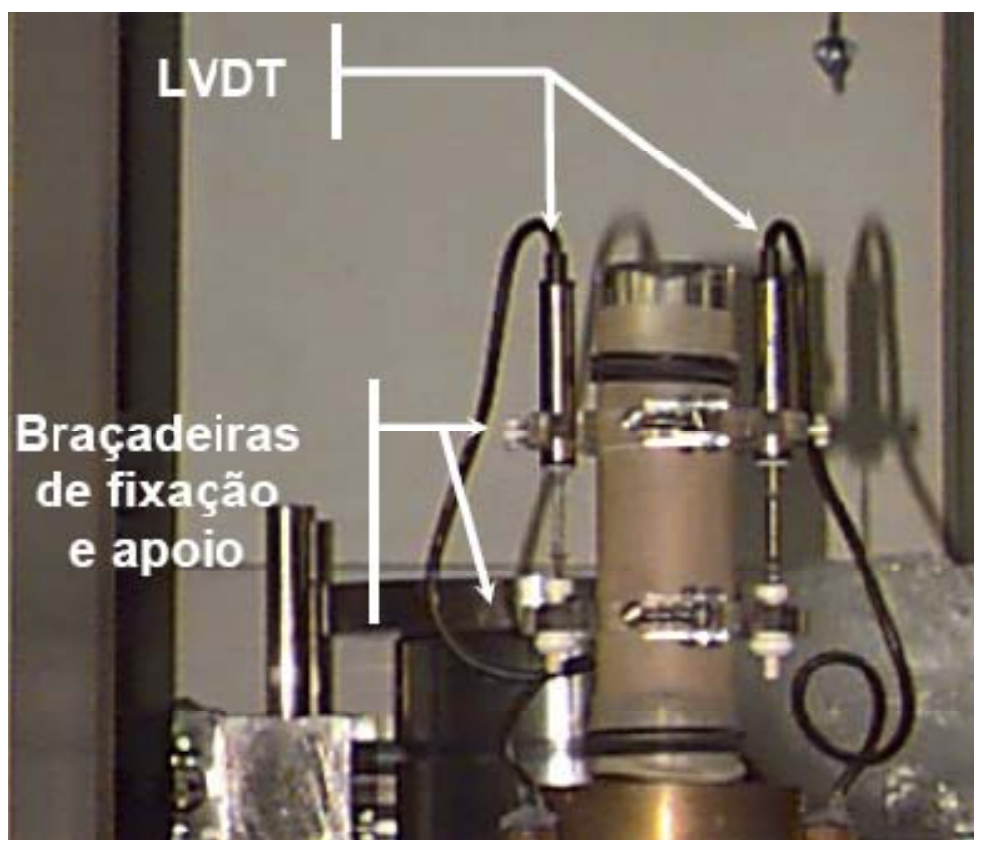

Figura 3.14: LVDT's instalados nos terços médios do corpo-de-prova

Os ensaios foram realizados conforme os níveis de tensões preconizados na norma "Standard Method of Test for Determining the Resilient Modulus of Soils and Aggregate Materials" (AASHTO Designation: T 307-99). Este método descreve procedimentos de preparação e ensaio de materiais de base e sub-base não tratados, para a determinação do módulo de resiliência $\left(M_{R}\right)$ sob condições que simulam o estado físico e o estado de tensões dos materiais sob pavimentos flexíveis sujeitos às cargas de roda. Os níveis de tensões a que são submetidos os corpos-de-prova para determinação do $M_{R}$ são determinados por sua localização na estrutura do pavimento. 


\subsubsection{Determinação dos módulos de resiliência em função do estado de tensão.}

A Tabela 3.8 apresenta a seqüência de tensões usada para ensaio de materiais de base e sub-base, seqüência definida pela AASHTO Designation: T 307-99

Tabela 3.8: Seqüência de ensaio para base/sub-base segundo a AASHTO T 307-99

\begin{tabular}{|c|c|c|c|c|c|}
\hline Seqüência & $\begin{array}{c}\text { Tensão } \\
\text { confinante } \\
\sigma_{3}(\mathrm{kPa})\end{array}$ & $\begin{array}{l}\text { Tensão } \\
\text { máxima } \\
\sigma_{1}(\mathrm{kPa})\end{array}$ & $\begin{array}{c}\text { Tensão } \\
\text { de contato } \\
\sigma_{\mathrm{c}}(\mathrm{kPa})\end{array}$ & $\begin{array}{c}\text { Tensão } \\
\text { desvio } \\
\sigma_{d}(\mathrm{kPa})\end{array}$ & $\begin{array}{l}\text { Número de } \\
\text { aplicações } \\
\text { de carga }\end{array}$ \\
\hline 0 & 103,4 & 103,4 & 10,3 & 93,1 & $500-1000$ \\
\hline 1 & \multirow{3}{*}{20,7} & 24,3 & 2,1 & 22,2 & 100 \\
\hline 2 & & 47,7 & 4,1 & 43,6 & 100 \\
\hline 3 & & 74,3 & 6,2 & 68,1 & 100 \\
\hline 4 & \multirow{3}{*}{34,5} & 41,8 & 3,5 & 38,3 & 100 \\
\hline 5 & & 82,1 & 6,9 & 75,2 & 100 \\
\hline 6 & & 125,8 & 10,3 & 115,5 & 100 \\
\hline 7 & \multirow{3}{*}{52,5} & 62,5 & 5,3 & 57,2 & 100 \\
\hline 8 & & 126,3 & 10,5 & 115,8 & 100 \\
\hline 9 & & 188,8 & 15,8 & 173 & 100 \\
\hline 10 & \multirow{3}{*}{68,9} & 83,3 & 6,9 & 76,4 & 100 \\
\hline 11 & & 165,3 & 13,8 & 151,5 & 100 \\
\hline 12 & & 243,2 & 20,7 & 222,5 & 100 \\
\hline 13 & \multirow{3}{*}{103,4} & 83,6 & 6,9 & 76,7 & 100 \\
\hline 14 & & 128,5 & 10,3 & 118,2 & 100 \\
\hline 15 & & 251,9 & 20,7 & 231,2 & 100 \\
\hline 16 & \multirow{3}{*}{137,9} & 128,7 & 10,3 & 118,4 & 100 \\
\hline 17 & & 168,7 & 13,8 & 154,9 & 100 \\
\hline 18 & & 304,7 & 27,6 & 277,1 & 100 \\
\hline
\end{tabular}

A forma de carregamento usada é triangular, com período de carga de $0,1 \mathrm{~s}$, e $0,9 \mathrm{~s}$ de repouso, ou seja, uma freqüência de $1 \mathrm{~Hz}$. Para cada um dos níveis de tensão da seqüência de ensaio considerada são armazenadas as informações de todos os ciclos de carregamento, entretanto, apenas os últimos cinco ciclos são considerados nos cálculos. 
Quatro canais fazem as leituras e os dados são armazenados num computador, onde é possível obter as informações sobre o deslocamento (canais 3 e 2), carga cíclica (canal 1) e pressão de confinamento (canal 0). Dessa forma, é possível determinar a carga cíclica e a pressão confinante efetivamente aplicadas em cada ciclo de carregamento e os deslocamentos resultantes. O deslocamento resiliente de cada ciclo é obtido pela média dos deslocamentos registrados nos dois LVDTs. A média dos deslocamentos resilientes dos últimos cinco ciclos define o valor adotado para o cálculo da deformação resiliente $\left(\varepsilon_{R}\right)$.

Conforme apresentado na Equação 3.4, o valor da deformação resiliente é dado por:

onde:

$$
\varepsilon_{\mathrm{R}}=\frac{\Delta \mathrm{h}}{\mathrm{H}}
$$

$\varepsilon_{R}-$ deformação resiliente;

$\Delta \mathbf{h}$ - média dos deslocamentos resilientes $(\mathrm{mm})$ nos últimos cinco ciclos;

H - altura inicial (mm) do trecho onde são instalados os LVDTs.

O módulo de resiliência $\left(M_{R}\right)$ é então calculado para cada estado de tensão pela Equação 3.5 .

$$
M_{R}=\frac{\sigma_{d}}{\varepsilon_{R}}
$$

onde:

$M_{R}-$ módulo de resiliência;

$\sigma_{d}-$ tensão desvio aplicada;

$\varepsilon_{R}-$ deformação resiliente. 


\subsection{ESTUDO DA INFLUÊNCIA DO TEMPO DE CURA}

Com o propósito de se avaliar a influência do tempo de cura no comportamento mecânico das misturas, avaliou-se inicialmente os resultados de resistência para ensaios com o tempo de 7 dias de cura.

As composições escolhidas para o estudo da influência do tempo de cura foram as misturas solo-cal com $10 \%$ de cal e solo-resíduo-cal com $40 \%$ de resíduo e $10 \%$ de cal por apresentarem as maiores resistências entre as misturas solo-cal e solo-resíduo-cal. Este estudo foi realizado utilizando-se o solo argiloso laterítico (LG') e o solo argiloso nãolaterítico (NG') na fração de solo das misturas. O solo arenoso laterítico (LA') não foi utilizado para o estudo da influência do tempo de cura, pois apresentou um aumento de resistência inexpressivo, não se mostrando promissor para o estudo em questão.

Foram realizados com estas misturas, ensaios imediatos de compressão simples e de compressão diametral e para 3, 7, 28 e 84 dias de cura na câmara úmida. Após a cura dos corpos-de-prova, cada mistura foi submetida aos ensaios sem imersão e após imersão prévia em água por um período de 4 horas. Isto permitiu avaliar o efeito pozolânico sobre as misturas devido à cal e ao resíduo. Os procedimentos de moldagem e ensaios foram os mesmos estabelecidos no Item 3.5.

\subsection{ENSAIOS AMBIENTAIS}

A estabilização é um dos tratamentos físico-químicos empregados em materiais constituídos com resíduos. O material obtido deve ter características e integridade física, de forma a otimizar a sua disposição e/ou reutilização. É possível que haja ocorrências de interferências causadas pelos constituintes químicos do resíduo, afetando a estabilidade 
química da mistura e, conseqüentemente, aumentar o seu potencial de lixiviabilidade e/ou solubilidade. Observa-se que o ensaio de lixiviação tem como finalidade identificar a concentração de substâncias que se separam do material por meio de lavagem e percolação, enquanto o ensaio de solubilização identifica a concentração das substâncias solúveis em água. Neste sentido, a lixiviação e a solubilização é um dos principais parâmetros que devem ser utilizados para a avaliação de materiais constituídos com resíduos submetidos ao processo de estabilização.

Os órgãos ambientais estabelecem testes de lixiviação e solubilização com a finalidade de classificar os resíduos quanto à sua toxidade, propondo recomendações e restrições quanto ao tipo de tratamento a ser empregado. No Brasil, não há uma regulamentação específica de testes de lixiviação ou solubilização para resíduos submetidos à técnica estabilização. Sendo os ensaios de lixiviação e solubilização realizados conforme a NBR 10005/2004 "Lixiviação de resíduos sólidos" e NBR 10006/2004 "Solubilização de resíduos sólidos", respectivamente. Ambas as normas são de aplicação geral para qualquer tipo de resíduo, abordando um único cenário de disposição e não levam em consideração as características específicas do resíduo in natura, nem de suas misturas com outros materiais.

Os trabalhos experimentais foram realizados no Laboratório de Saneamento da EESC/USP de acordo com as normas supracitadas e a norma NBR 10004/2004, esta última classifica os limites máximos permitidos de elementos poluentes presentes no extrato, apresentando-os nos anexos normativos $F$ e $G$, respectivamente para os ensaios de lixiviação e solubilização, também classifica os resíduos sólidos em dois grupos, Classe I perigosos e Classe II - não perigosos, sendo este último grupo subdividido em Classe II A não inertes e Classe II B - inertes.

Escolheu-se dentre os três solos estudados, o solo de comportamento não-laterítico (NG'), devido a este apresentar maiores resistências e rigidezes ao longo do tempo. 
Realizou-se também, ensaios no resíduo da fabricação de papel e na mistura solo-resíduocal. Os corpos-de-prova foram moldados na umidade ótima $\left(\omega_{0}\right)$ e massa específica seca máxima ( $\left.\rho_{\text {dmáx }}\right)$, exceto para o resíduo. Para a mistura foram utilizados teores de $50 \%$ de solo, $40 \%$ de resíduo e $10 \%$ de cal. No Departamento de Estradas de Transportes da EESC/USP, os corpos-de-prova foram compactados estaticamente em três camadas, utilizando-se o molde cilíndrico metálico de diâmetro interno de $5,0 \mathrm{~cm}$ e altura de $10,0 \mathrm{~cm}$, conforme já apresentado para o ensaio de compressão simples. Sendo os materiais levados para a câmara úmida, onde passaram um período de cura de 7 dias. Em seguida, os corpos-de-prova foram triturados e levados ao Laboratório de Saneamento.

\subsection{ANÁLISE DOS RESULTADOS}

\subsubsection{Método de aceitação dos resultados}

A análise dos resultados dos ensaios de compressão simples, compressão diametral e módulo de resiliência foi feita com base nos valores estatísticos de média e desvio padrão, sendo aplicado o teste de Grubbs para identificação de outliers (GRUBBS, 1969).

O teste de Grubbs é definido por duas hipóteses, uma hipótese nula $\left(\mathrm{H}_{0}\right)$ onde não existe nenhum outlier, e uma hipótese não nula $\left(\mathrm{H}_{1}\right)$ onde existe pelo menos um outlier nos resultados. Assim para a identificação de um outlier, o teste de Grubbs se baseia em comparar um valor estatístico $(G)$ calculado a partir das amostras analisadas com um valor crítico $\left(\mathrm{G}_{\text {crítico }}\right)$ que depende do número de repetições e grau de confiança adotado. O valor estatístico G é calculado a partir da Equação 3.4. 


$$
G=\frac{\max \left|Y_{i}-\bar{Y}\right|}{s}
$$

onde:

$Y_{i}$ - valores máximos e mínimos dentro do conjunto de resultados de um mesmo tratamento;

$\overline{\mathrm{Y}}$ - média dos resultados de um mesmo tratamento;

$s$ - desvio padrão dos resultados de um mesmo tratamento.

Para as análises estatísticas desse trabalho adotou-se o número de repetições igual a três $(\mathrm{N}=3)$ que corresponde à quantidade de corpos-de-prova por ensaio e um nível de confiança de $95 \%$. Assim, o $G_{\text {criticos }}$ utilizado é 1,15, segundo valores críticos em função do número de repetições e do nível de confiança adotado por Grubbs (1969).

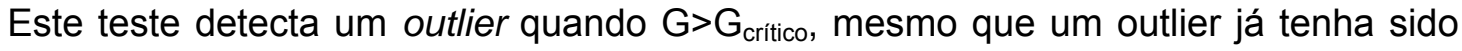
eliminado dos dados. O teste deve se repetir até que não sejam detectados mais outliers, assim quando a hipótese nula $\mathrm{H}_{0}$ se manifestar, pode-se assumir que todas as observações vêm de uma distribuição normal.

\subsubsection{Análise de variância}

Foi feita a análise de variância dos resultados dos ensaios de compressão simples, compressão diametral e módulo de resiliência, verificando-se a influência do tipo de solo, teor de resíduo, teor de cal, imersão em água e tempo de cura.

A metodologia de análise de variância (ANOVA) ${ }^{1}$ trata-se de um procedimento estatístico que faz comparações simultâneas entre médias populacionais e que nos permite verificar o efeito dos fatores analisados a partir de um teste de hipótese. Um teste de 
hipótese é uma regra na qual, conduz à decisão de aceitar ou rejeitar a hipótese considerada.

Para a análise de variância, utiliza-se como teste de hipótese o teste-F, que se baseia em comparar um valor $\mathrm{F}$ calculado a partir de ensaios laboratoriais com os valores de $F_{\text {teórico, }}$ que são tabelados em função do grau de liberdade dos tratamentos, do erro e do nível de confiança adotado. Se o valor de $F_{\text {calculado }}$ for maior que o valor de $F_{\text {teórico, }}$ pode-se afirmar, com o nível de confiança adotado, que a hipótese é aceita.

A validade dos testes estatísticos depende da existência de réplicas, pois estas fornecem uma estimativa do erro aleatório, o que torna possível o uso de tabelas de significância, construídas sob a consideração de que os erros são independentes (GARCIADIAZ \& PHILLIPS, 1995).

${ }^{1}$ ANOVA - (Analysis of variance): Técnica estatística introduzida por Fisher em 1939. 


\section{APRESENTAÇÃO E ANÁLISE DOS RESULTADOS}

\subsection{CONSIDERAÇÕES INICIAIS}

Os ensaios de compactação, compressão simples, tração indireta e triaxial cíclico foram realizados com o propósito de avaliar o comportamento de misturas compactadas constituídas por solo, resíduo da produção da pasta de celulose e cal, combinados segundo diferentes proporções, de acordo com o Item 3.4. Realizaram-se os ensaios variando-se o teor de resíduo e cal para os tempos de cura 0, 2, 7, 28 e 84 dias e para os corpos-de-prova imersos e não imersos em água. Avaliou-se, ainda, através da análise dos resultados de ensaios ambientais, se o resíduo da fabricação de papel e celulose incorporado à mistura solo-cal é ou não um fator de contaminação do meio ambiente e, portanto, constitui-se ou não em um risco potencial à saúde.

\subsection{ANÁLISE DOS RESULTADOS DOS ENSAIOS DE COMPACTAÇÃO}

\subsubsection{Determinação do teor de resíduo máximo na mistura}


Os ensaios de compactação das misturas foram realizados na energia normal do ensaio de Proctor para determinação dos correspondentes valores de massa específica seca máxima $\left(\rho_{\mathrm{dmax}}\right)$ e umidade ótima $\left(\omega_{0}\right)$.

Preliminarmente, foram ensaiadas misturas de solo, sem adição de cal, e diversos teores de resíduo para se determinar o maior teor trabalhável deste material durante a compactação passível de ser adicionado à mistura. O teor máximo obtido foi de $40 \%$. Teores maiores de resíduo aumentam de tal forma a plasticidade da mistura que a mesma passa a aderir no cilindro de compactação, interferindo assim na transferência da energia de compactação e conseqüentemente no resultado do ensaio de compactação.

A Tabela 4.1 apresenta a massa específica seca máxima e a umidade ótima obtidas nos ensaios realizados para se determinar o máximo teor de resíduo a ser considerado na constituição das misturas compostas pelos solos argilosos de comportamento laterítico (LG') e não-laterítico (NG'), sem adição de cal. Nessa tabela são também apresentadas as variações de $\rho_{\mathrm{dmax}}$ e $\omega_{\mathrm{o}}$ calculadas para os diversos teores de resíduo com relação a estes parâmetros determinados para os solos sem resíduo. A Figura 4.1 apresenta as curvas de compactação determinadas nestes mesmos ensaios. Destaca-se que esta análise não foi realizada para misturas com resíduo constituídas com o solo arenoso laterítico (LA').

Tabela 4.1 - Massa específica seca máxima e umidade ótima das misturas de resíduo e solo, sem adição de cal

\begin{tabular}{|c|c|c|c|c|c|c|}
\hline Tipo de solo & Solo (\%) & $\begin{array}{c}\text { Resíduo } \\
(\%)\end{array}$ & $\begin{array}{c}\rho_{\mathrm{dmax}} \\
\left(\mathbf{g} / \mathrm{cm}^{3}\right)\end{array}$ & $\begin{array}{c}\text { Variação } \\
(\%)\end{array}$ & $\omega_{0}(\%)$ & $\begin{array}{c}\text { Variação } \\
(\%)\end{array}$ \\
\hline \multirow{4}{*}{$\begin{array}{l}\text { Argiloso } \\
\text { Não- } \\
\text { Laterítico } \\
\text { (NG') }\end{array}$} & 100 & 0 & 1,549 & & 23,50 & \\
\hline & 60 & 40 & 1,450 & $-6,4$ & 27,30 & 13,9 \\
\hline & 55 & 45 & 1,431 & $-7,6$ & 28,10 & 16,4 \\
\hline & 50 & 50 & 1,421 & $-8,3$ & 28,60 & 17,8 \\
\hline \multirow{4}{*}{$\begin{array}{c}\text { Argiloso } \\
\text { Laterítico } \\
\text { (LG') }\end{array}$} & 100 & 0 & 1,572 & & 24,40 & \\
\hline & 60 & 40 & 1,482 & $-5,7$ & 26,90 & 9,3 \\
\hline & 55 & 45 & 1,471 & $-6,4$ & 27,60 & 11,6 \\
\hline & 50 & 50 & 1,452 & $-7,6$ & 28,20 & 13,3 \\
\hline
\end{tabular}




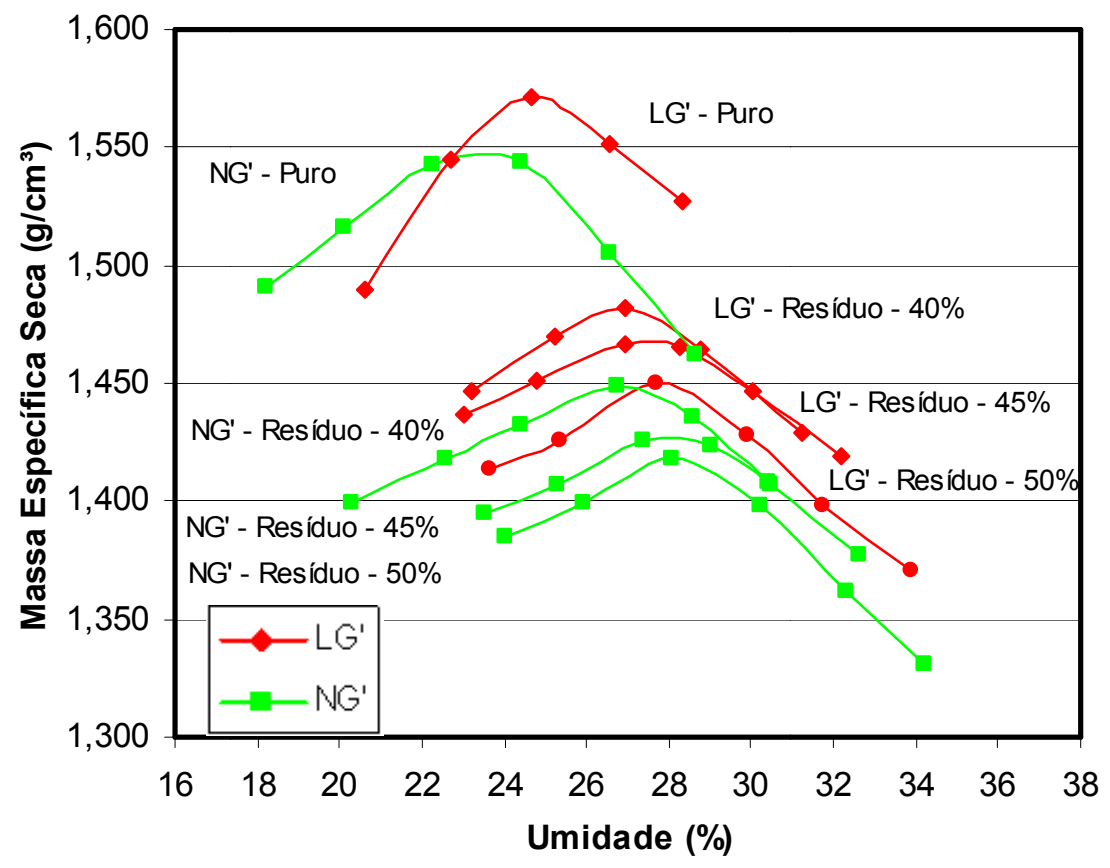

Figura 4.1 - Curvas de compactação dos solos e das misturas de solo e resíduo, sem adição de cal

Analisando-se os valores apresentados na Tabela 4.1 e ilustrados na Figura 4.1, observa-se, que o valor de massa específica seca máxima do solo argiloso laterítico (LG’) apresenta-se $1,48 \%$ maior que o valor do solo argiloso não-laterítico (NG'). Este resultado confirma a expectativa, de que, para solos granulometricamente semelhantes, o solo de comportamento laterítico apresente $\rho_{\mathrm{dmax}}$ maior que a do solo de comportamento nãolaterítico.

Com relação à umidade ótima, ainda analisando os valores apresentados na Tabela 4.1 e a Figura 4.1, observa-se que o valor da $\omega_{\circ}$ do solo argiloso laterítico (LG') apresentase $3,83 \%$ maior que o valor do solo argiloso não-laterítico (NG'). Este resultado poderia ser atribuído ao fato do teor de finos do solo LG' (83\%) ser maior quando comparado com o teor de finos do solo NG' (75\%). Entretanto, se a maior quantidade de finos explica o maior valor da umidade ótima do solo LG', essa justificativa conflita com o maior valor de $\rho_{\mathrm{dmax}}$, observado para este solo, visto que solos mais finos apresentam menores valores de massa específica seca máxima. 
Comparando-se os valores de massa específica seca máxima e umidade ótima das misturas com resíduo, sem adição de cal, do solo laterítico e não-laterítico, com os valores destes parâmetros correspondentes aos solos puros, observa-se que a $\rho_{\mathrm{dmax}}$ reduz-se, em média, $6,6 \%$ e $7,4 \%$, e a $\omega_{\circ}$ aumenta, em média, $11,4 \%$ e $16,0 \%$, respectivamente para os solos LG' e NG', quando se adiciona o resíduo. Estas variações podem ser atribuídas ao aumento do teor de finos, resultado do acréscimo de resíduo, material com $97,5 \%$ passando na peneira \#200.

Destaca-se que as misturas com resíduo compostas pelos solos LG' e NG' apresentam valores médios de massa específica seca máxima de $1,468 \mathrm{~g} / \mathrm{cm}^{3}$ e 1,434 $\mathrm{g} / \mathrm{cm}^{3}$, e de umidade ótima de $27,6 \%$ e $28,0 \%$, respectivamente. Assim, apesar das misturas com o solo NG' apresentarem maiores variações de $\rho_{\text {dmax }}$ e $\omega_{0}$ quando comparadas às misturas com o solo LG', conforme mostrado anteriormente, observa-se que os valores médios destes parâmetros são muito próximos para os dois solos, evidenciando que a gênese dos materiais tem pouca influência nos resultados dos ensaios de compactação das misturas de solo e resíduo.

\subsubsection{Misturas solo-cal, solo-resíduo e solo-resíduo-cal}

Conforme destacado no Capítulo 3, além das misturas constituídas com solo e resíduo estabilizadas com cal, foram ensaiadas também misturas do tipo solo-cal, sem adição de resíduo. Para o solo arenoso laterítico (LA'), não foram ensaiadas misturas solocal.

A Tabela 4.2 apresenta a massa específica seca máxima e a umidade ótima das misturas compostas com $0 \%, 5 \%$ e $10 \%$ de cal, sem a adição de resíduo e com $40 \%$ de 
resíduo para os solos NG', LG' e LA' e as Figuras 4.2, 4.3 e 4.4 mostram, respectivamente, as curvas de compactação correspondentes.

Tabela 4.2 - Massa específica seca máxima e umidade ótima dos solos, das misturas de solocal e das misturas de solo-resíduo-cal

\begin{tabular}{cccccc}
\hline Tipo de solo & Solo (\%) & Resíduo (\%) & Cal (\%) & $\boldsymbol{\rho}_{\text {dmax }}\left(\mathbf{g} / \mathbf{c m}^{\mathbf{3}}\right)$ & $\boldsymbol{\omega}_{\mathbf{o}}(\mathbf{\%})$ \\
\hline & 100 & 0 & 0 & 1,572 & 24,4 \\
Argiloso & 95 & 0 & 5 & 1,542 & 25,8 \\
Laterítico & 90 & 0 & 10 & 1,514 & 26,1 \\
(LG') & 60 & 40 & 0 & 1,482 & 26,9 \\
& 55 & 40 & 5 & 1,468 & 27,4 \\
& 50 & 40 & 10 & 1,426 & 29,6 \\
\hline Nrgiloso & 100 & 0 & 0 & 1,549 & 23,5 \\
Não-Laterítico & 95 & 0 & 5 & 1,503 & 24,5 \\
(NG') & 90 & 0 & 10 & 1,494 & 25,1 \\
& 55 & 40 & 0 & 1,450 & 27,3 \\
& 50 & 40 & 5 & 1,405 & 28,8 \\
& 50 & 10 & 1,367 & 29,4 \\
\hline Arenoso & 100 & 0 & 0 & 1,900 & 10,8 \\
Laterítico & 60 & 40 & 0 & 1,676 & 16,6 \\
(LA') & 55 & 40 & 5 & 1,594 & 19,8 \\
& 50 & 40 & 10 & 1,516 & 23,2 \\
\hline
\end{tabular}
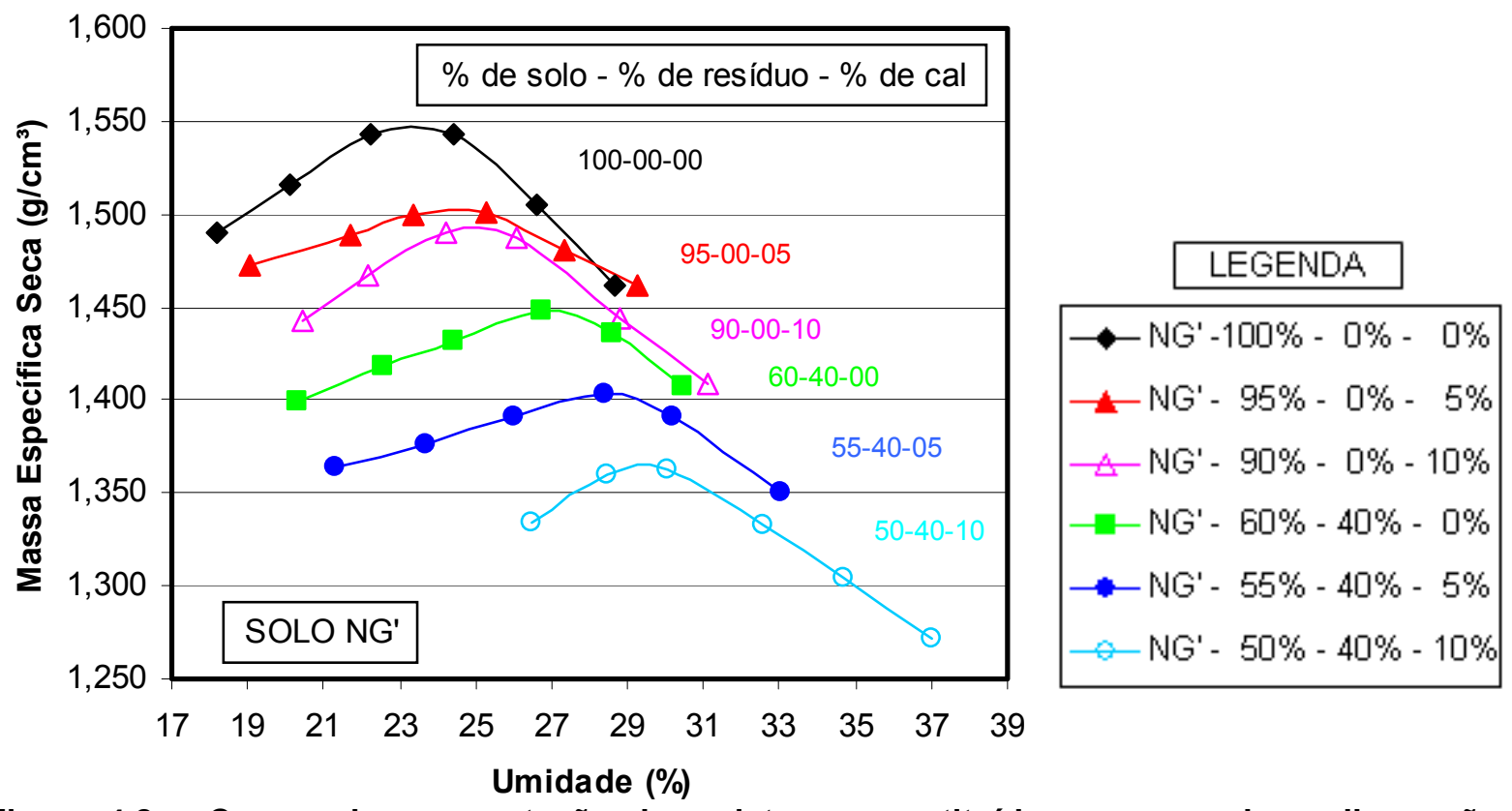

Figura 4.2 - Curvas de compactação das misturas constituídas com o solo argiloso nãolaterítico (NG') 


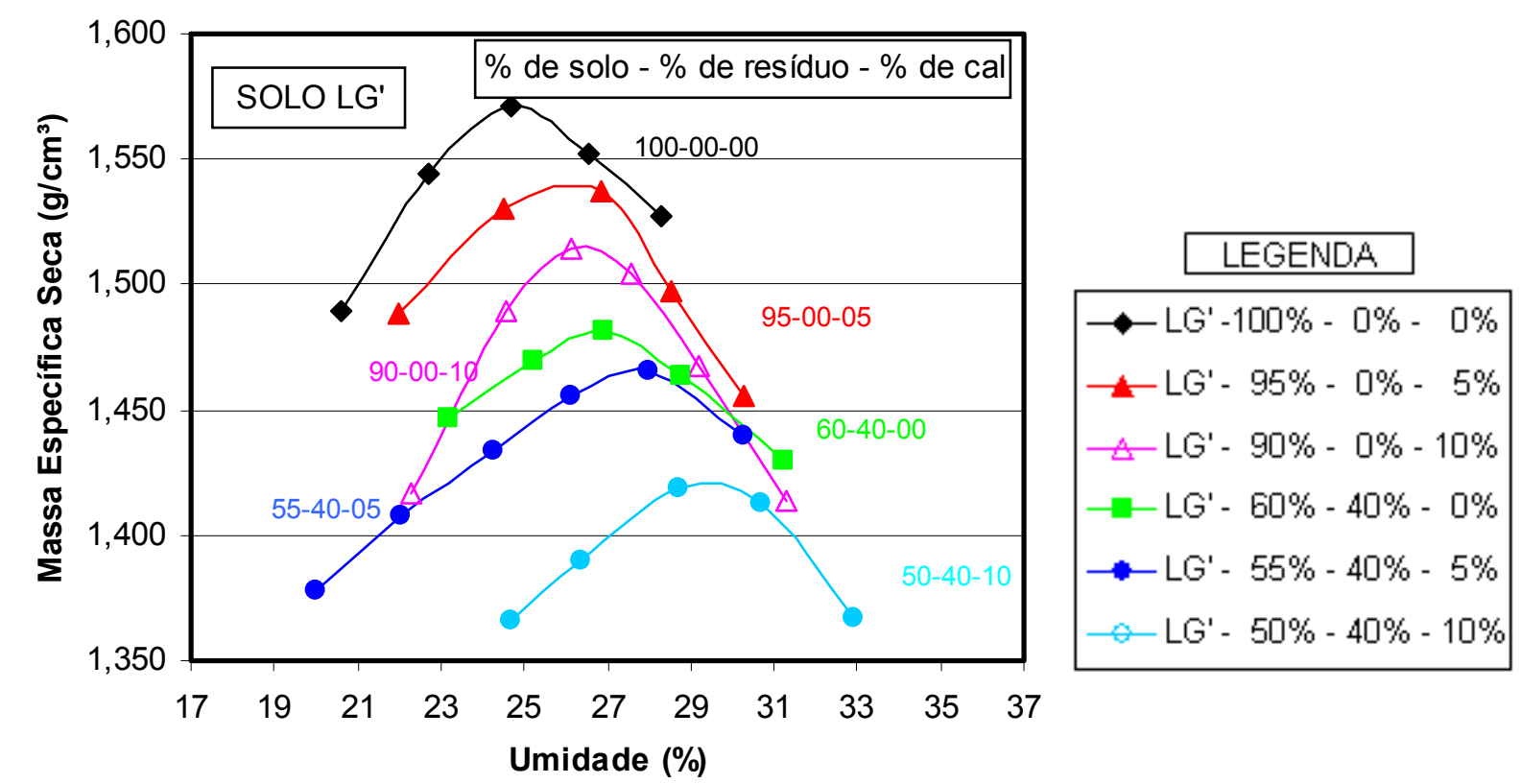

Figura 4.3 - Curvas de compactação das misturas constituídas com o solo argiloso laterítico (LG')

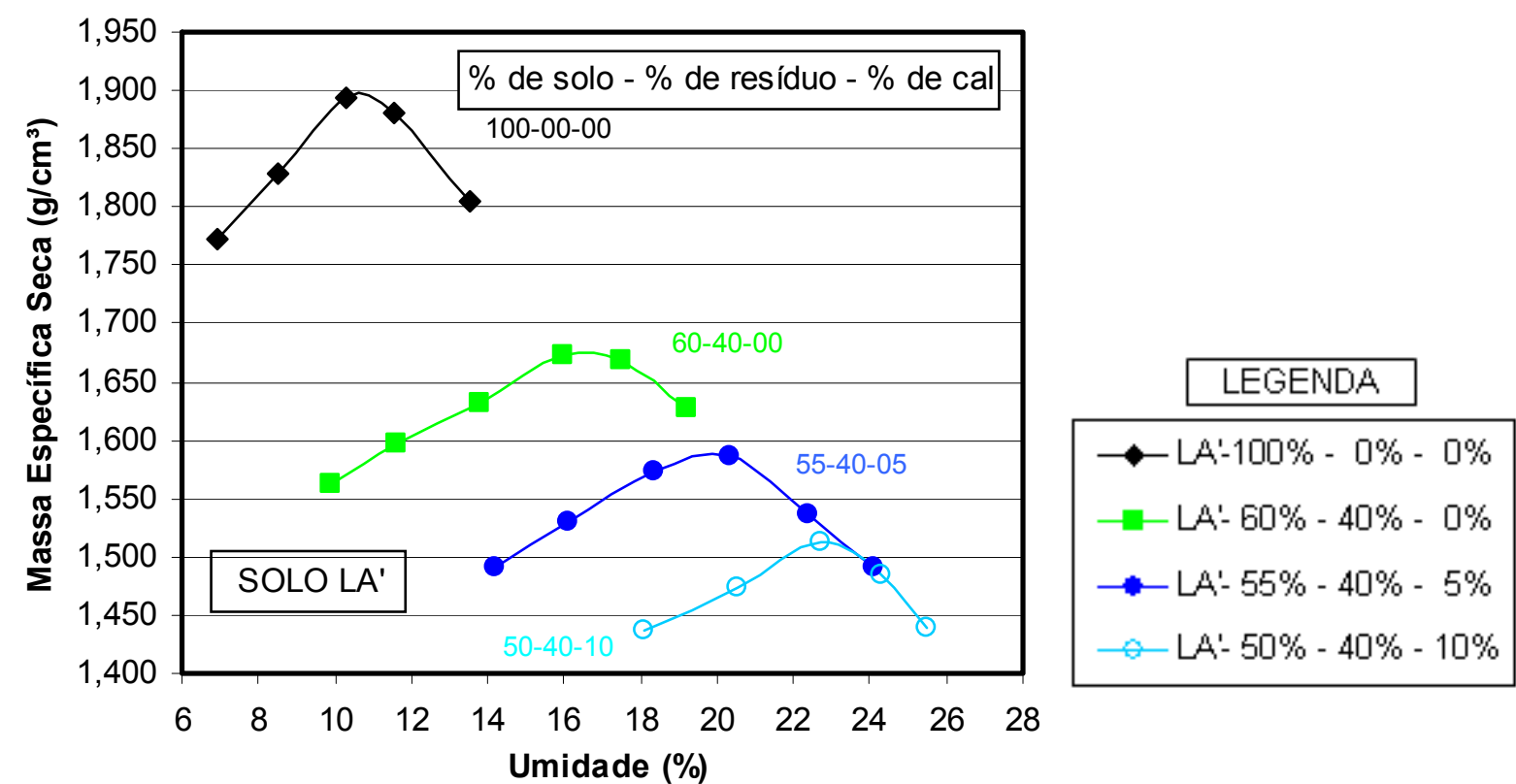

Figura 4.4 - Curvas de compactação das misturas constituídas com o solo arenoso laterítico (LA')

Analisando-se os valores apresentados na Tabela 4.2 e ilustrados nas Figuras 4.2, 4.3 e 4.4, observa-se que a adição de resíduo conduz a uma diminuição da massa específica seca máxima e um aumento da umidade ótima para todas as misturas, independente do tipo de solo e do teor de cal utilizados. Por outro lado, a adição ou aumento do teor de cal também age no mesmo sentido, diminuindo a $\rho_{\mathrm{dmax}}$ e aumentado a $\omega_{\mathrm{o}}$. Este 
comportamento é comumente observado para misturas de solo-cal, segundo dados apresentados na State of the art 5 - Lime stabilization (TRB, 1987).

Nos ensaios de compactação das misturas analisadas por Molina (2004) foi constatado, de forma geral que, a adição ou o aumento do teor de cal conduziram a uma suavização das curvas de compactação tanto para as misturas sem resíduo, como para as misturas com resíduo, indicando que a $\rho_{\mathrm{dmax}}$ das misturas com cal apresentaram-se menos sensíveis à variação da umidade de compactação. Neste trabalho, a suavização das curvas de compactação devido à adição ou aumento do teor de cal apresenta-se de forma discreta para as misturas com solo NG', entretanto, para as misturas com solo LG' e LA' tal comportamento não é observado.

Considerando-se o efeito da adição ou aumento do teor de cal, as Figuras 4.5 e 4.6 ilustram a variação da massa específica seca máxima com o teor de cal para misturas sem resíduo e com $40 \%$ de resíduo para o solo argiloso não-laterítico (NG') e argiloso laterítico (LG'), respectivamente.

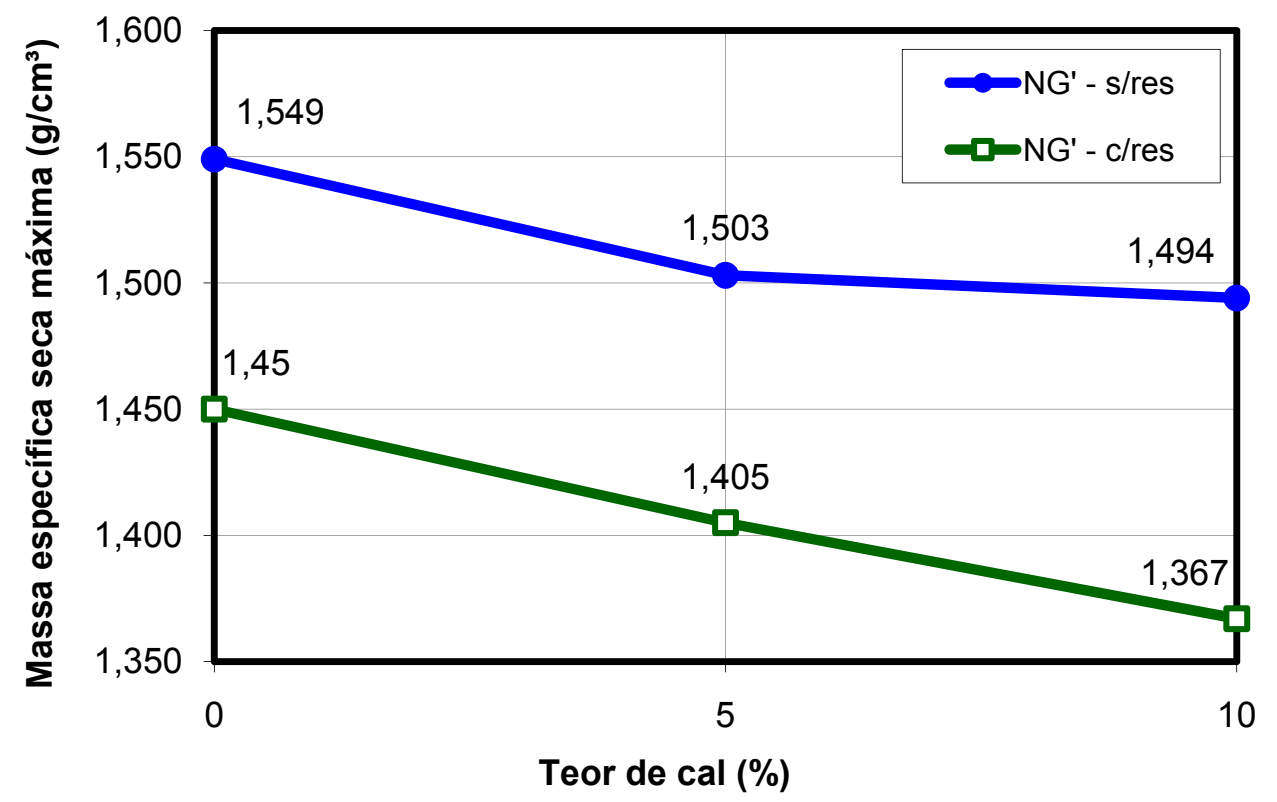

Figura 4.5 - Massa específica seca máxima em função do teor de cal para as misturas com solo argiloso não-laterítico (NG'), sem resíduo e com $40 \%$ de resíduo 


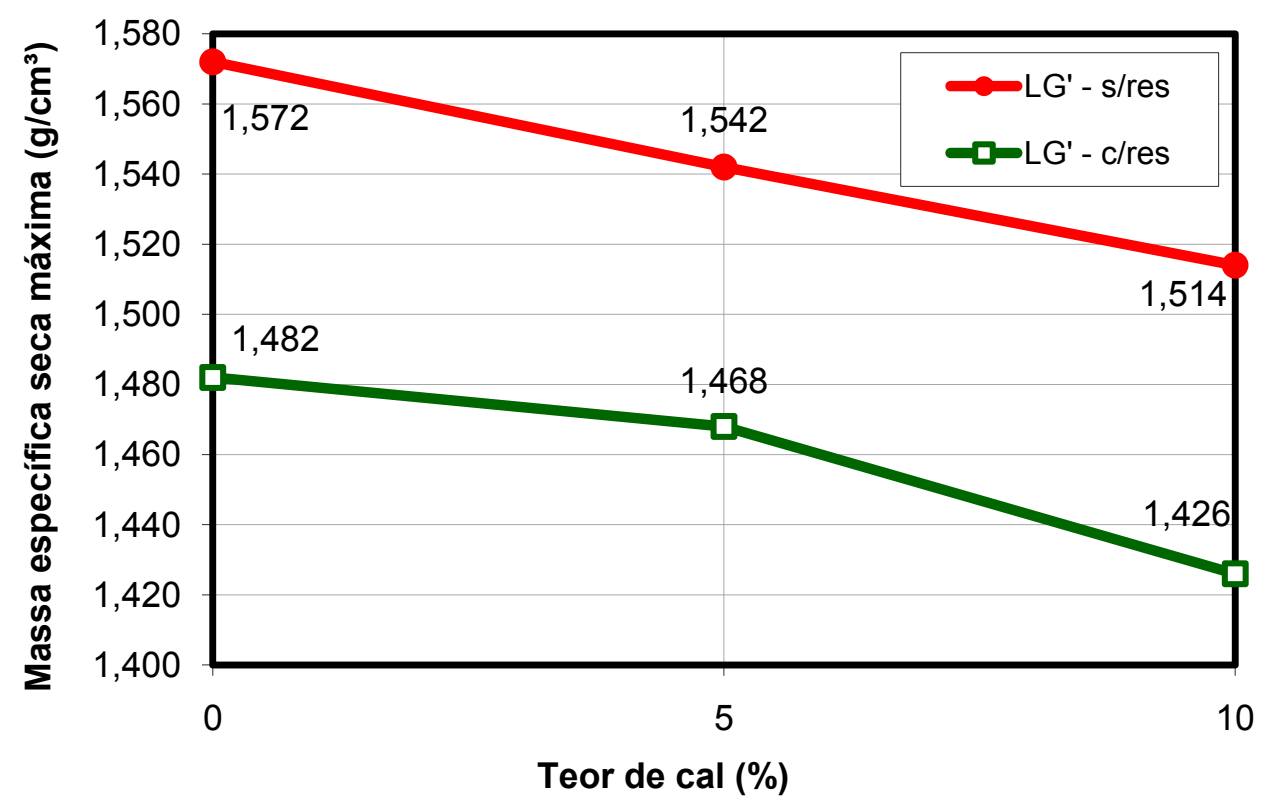

Figura 4.6 - Massa específica seca máxima em função do teor de cal para as misturas com solo argiloso laterítico (LG'), sem resíduo e com $40 \%$ de resíduo

Analisando-se as Figuras 4.5 e 4.6, observa-se que a diminuição da massa específica seca máxima com a adição ou aumento do teor de cal é pequena para todas as misturas, independentemente do tipo de solo e da presença ou não de resíduo. Verifica-se também, conforme destacado anteriormente, que a $\rho_{d m a x}$ diminui com a adição de resíduo e com o aumento do teor de cal, para os dois tipos de solos.

Deve-se destacar que as misturas sem resíduo constituídas pelos solos NG' e LG' têm uma diminuição na massa específica seca máxima, respectivamente, de 3,0\% e 1,9\% quando são adicionados $5 \%$ de cal, e uma diminuição de $3,6 \%$ e $3,7 \%$ quando são adicionados $10 \%$ de cal. Quanto às misturas com $40 \%$ de resíduo, as constituídas com os solos NG' e LG' têm uma diminuição na $\rho_{\mathrm{dmax}}$, respectivamente de $3,1 \%$ e $0,9 \%$ quando são adicionados $5 \%$ de cal. Para $10 \%$ de cal, a diminuição é de $5,7 \%$ e 3,8\% respectivamente. Portanto, de maneira geral, à exceção da mistura do solo NG' com 10\% de cal, as misturas com solo argiloso não-laterítico (NG') apresentam uma variação da massa específica seca máxima com adição da cal ligeiramente maior que a variação da $\rho_{\mathrm{dmax}}$ observada para as misturas constituídas com o solo laterítico (LG'). 
Comparando-se as massas específicas secas máximas de misturas sem resíduo e com $40 \%$ de resíduo compostas pelo solo NG' (conforme Figura 4.5), observa-se que a adição de resíduo produz uma diminuição de massa específica seca máxima de $6,4 \%, 6,5 \%$ e $8,5 \%$, respectivamente, para os teores de $0 \%, 5 \%$ e $10 \%$ de cal, conduzindo a uma queda, na média, igual a $7,1 \%$. Já para as misturas sem resíduo e com $40 \%$ de resíduo compostas pelo solo LG' (conforme Figura 4.6), a diminuição da $\rho_{\mathrm{dmax}}$ é de 5,7\%, 4,8\% e 5,8\%, para os teores de $0 \%, 5 \%$ e $10 \%$ de cal, respectivamente, conduzindo a uma queda, na média, igual a 5,4\%. No tocante à influência da adição de resíduo, o decréscimo da $\rho_{d m a x}$ é maior para as misturas com o solo NG' do que para as misturas com o solo LG' em uma proporção média de 4:3.

A Figura 4.7 apresenta a variação da massa específica seca máxima em função do teor de cal de misturas com $40 \%$ de resíduo compostas pelo solo argiloso não-laterítico (NG'), argiloso laterítico (LG') e arenoso laterítico (LA').

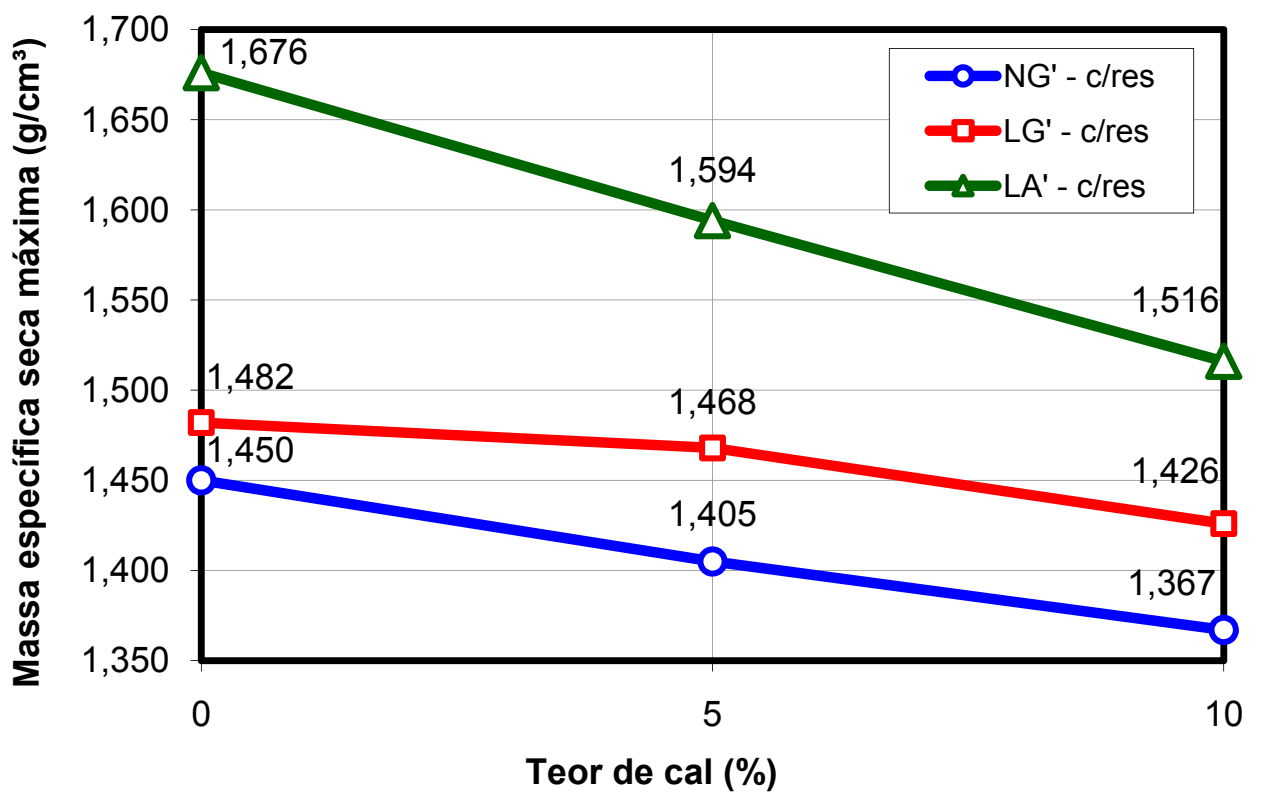

Figura 4.7 - Massa específica seca máxima em função do teor de cal para as misturas com solo argiloso não-laterítico (NG'), argiloso laterítico (LG') e arenoso laterítico (LA'), com $40 \%$ de resíduo 
Analisando-se a influência do teor de cal na Figura 4.7, para as misturas com $40 \%$ de resíduo compostas pelo solo arenoso laterítico (LA'), nota-se o mesmo comportamento observado para as misturas constituídas pelos demais solos com a adição ou aumento do teor de cal. Assim, comparando-se os valores de massa específica seca máxima das misturas com $40 \%$ de resíduo compostas pelo solo LA' com a média da $\rho_{\mathrm{dmax}}$ determinado a partir das misturas com os solos argilosos, nota-se uma variação de 12,5\%, 9,9\% e 7,9\%, respectivamente, para os teores de $0 \%, 5 \%$ e $10 \%$ de cal. Isto mostra que as misturas com o solo arenoso laterítico (LA') apresentam uma variação da $\rho_{\mathrm{dmax}}$ com a adição da cal maior que as observadas nas misturas constituídas pelo solo NG' e LG'

Ainda analisando a Figura 4.7, observa-se, quando se comparam as massas específicas secas máximas das diversas misturas, que as $\rho_{\mathrm{dmax}}$ das misturas com o solo LA' mostram-se maiores do que os valores correspondentes das misturas com os solos NG' e LG', fato que pode ser atribuído à granulometria do solo LA', que possui um teor de finos (27\%) significativamente menor quando comparado ao teor de finos dos solos LG' (83\%) e NG' $(75 \%)$.

Portanto, com base nas análises da massa específica seca máxima nas diversas composições estudadas (conforme Tabela 4.2), pode-se concluir que o comportamento laterítico do solo influencia pouco na variação da $\rho_{\mathrm{dmax}}$, visto que o par granulométrico constituído pelos solos NG' e LG' mostraram um comportamento muito semelhante quando se analisa a variação da $\rho_{\mathrm{dmax}}$ com o acréscimo do resíduo e com a variação do teor de cal. O comportamento diferenciado das misturas constituídas com o solo arenoso laterítico (LA') evidencia que a granulometria é o fator preponderante na variação da $\rho_{\mathrm{dmax}}$, se comparado com a influência da gênese do material. As Figuras 4.8 e 4.9 ilustram a variação da umidade ótima com o teor de cal para misturas sem resíduo e com $40 \%$ de resíduo para os solos NG' e LG', respectivamente. 


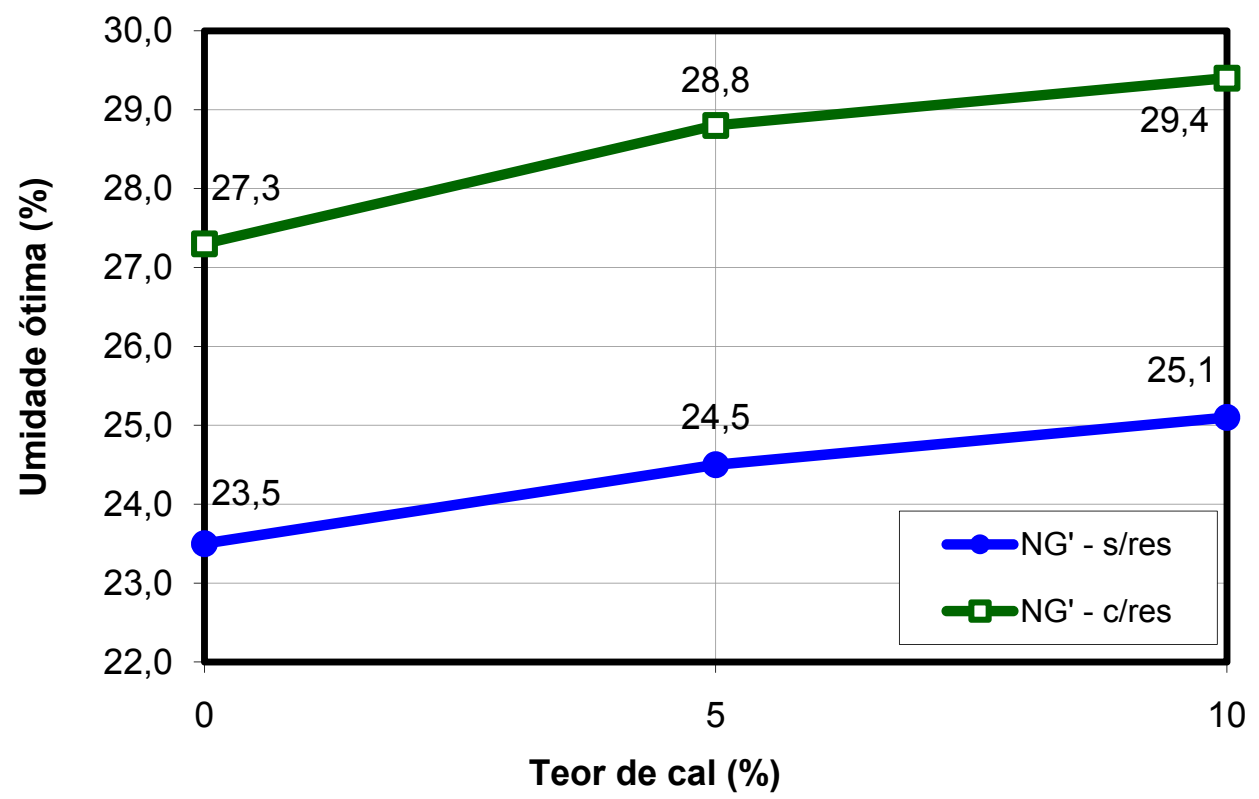

Figura 4.8 - Umidade ótima em função do teor de cal para as misturas com solo argiloso nãolaterítico (NG'), sem resíduo e com $40 \%$ de resíduo

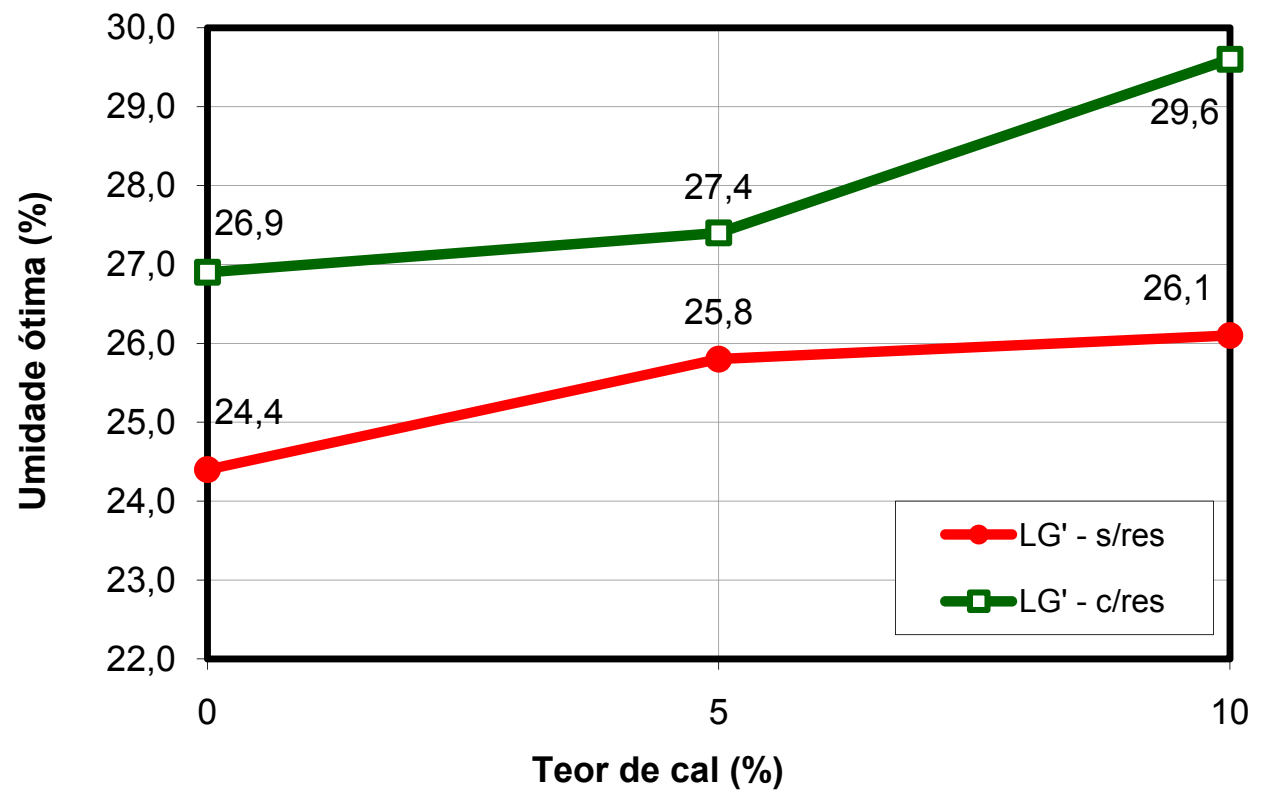

Figura 4.9 - Umidade ótima em função do teor de cal para as misturas com solo argiloso laterítico (LG'), sem resíduo e com $40 \%$ de resíduo

Analisando-se as Figuras 4.8 e 4.9, observa-se que o aumento da umidade ótima com a adição ou aumento do teor de cal é pequeno para todas as misturas, independentemente do tipo de solo e da presença ou não de resíduo. Verifica-se também, 
conforme destacado no Item 4.2.2, que a $\omega_{\text {o }}$ aumenta com a adição de resíduo e com o aumento do teor de cal, para os dois tipos de solos.

Destaca-se que as misturas sem resíduo constituídas pelos solos NG' e LG' têm aumento na umidade ótima, respectivamente, de $4,3 \%$ e $5,7 \%$ quando são adicionados $5 \%$ de cal, e um aumento de $6,8 \%$ e $7,0 \%$ quando são adicionados $10 \%$ de cal. Com relação às misturas com $40 \%$ de resíduo, as constituídas com os solos NG' e LG' têm um aumento na $\omega_{0}$, respectivamente, de $5,5 \%$ e $1,9 \%$, quando adicionado $5 \%$ de cal. Para $10 \%$ de cal, o aumento é de $7,3 \%$ e $10,0 \%$, respectivamente. Portanto, de maneira geral, à exceção da mistura do solo LG' com $40 \%$ de resíduo e $5 \%$ de cal, as misturas com solo argiloso laterítico (LG') apresentam uma variação da umidade ótima com adição da cal maior que a variação da $\omega_{0}$ observada para as misturas constituídas com o solo não-laterítico (NG').

Comparando-se as umidades ótimas de misturas sem resíduo e com 40\% de resíduo compostas pelo solo NG' (conforme Figura 4.8), observa-se que a adição de resíduo produz um aumento da umidade ótima de $16,2 \%, 17,6 \%$ e $16,7 \%$, respectivamente, para os teores de $0 \%, 5 \%$ e $10 \%$ de cal, conduzindo a um aumento, na média, igual a 16,8\%. Já para as misturas sem resíduo e com $40 \%$ de resíduo compostas pelo solo LG' (conforme Figura 4.9), o aumento da $\omega_{\mathrm{o}}$ é de $10,2 \%, 6,2 \%$ e $13,4 \%$, para os teores de $0 \%, 5 \%$ e $10 \%$ de cal, respectivamente, conduzindo a um aumento, na média, igual a 9,9\%. No tocante à influência da adição de resíduo, o acréscimo da $\omega_{0}$ é menor para as misturas com o solo LG' do que para as misturas com o solo NG' em uma proporção média de 1:2. Portanto, se comparada à massa específica seca, a influência da gênese do material é maior no aumento da umidade ótima com a adição do resíduo, visto que a relação para a $\rho_{\mathrm{dmax}}$ é de 4:3.

A Figura 4.10 apresenta a variação da umidade ótima em função do teor de cal de misturas com $40 \%$ de resíduo compostas pelo solo argiloso não-laterítico (NG'), argiloso laterítico (LG') e arenoso laterítico (LA'). 


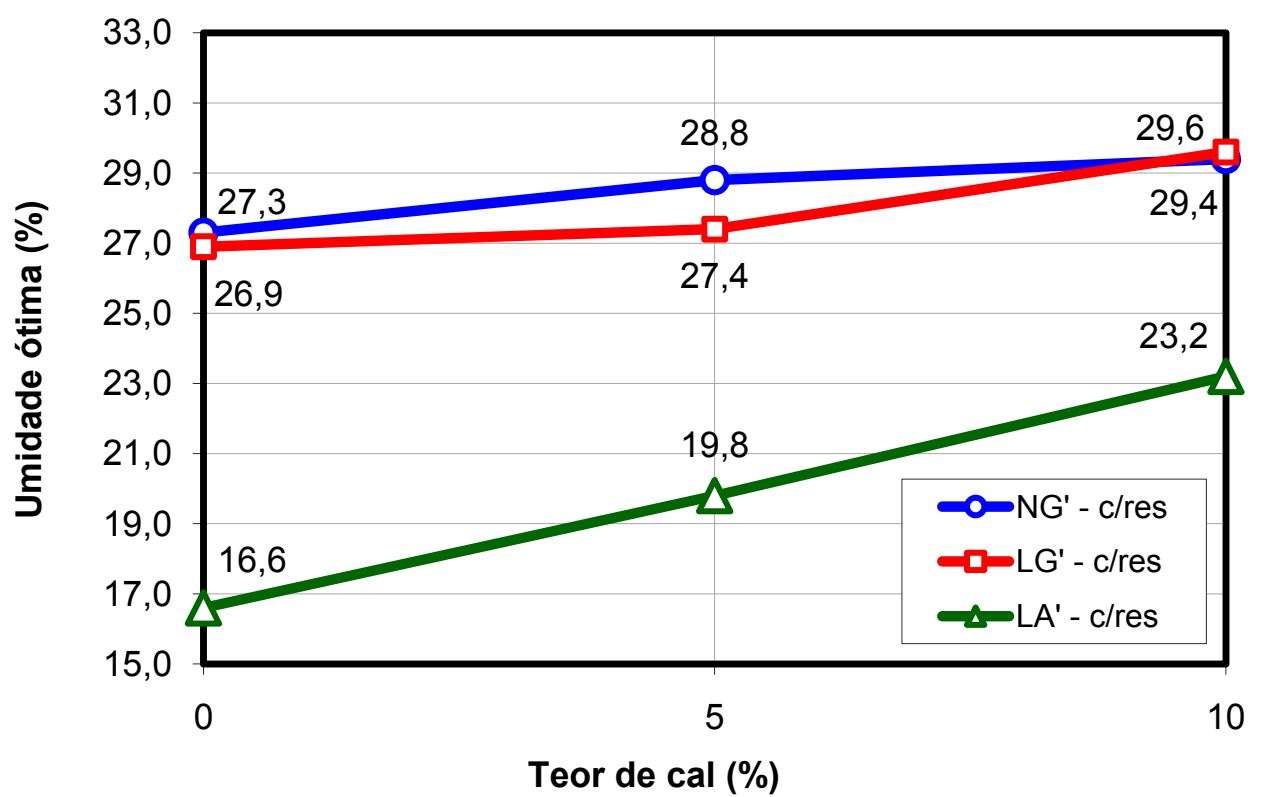

Figura 4.10 - Umidade ótima em função do teor de cal para as misturas com solo argiloso nãolaterítico (NG'), argiloso laterítico (LG') e arenoso laterítico (LA')

Analisando-se a Figura 4.10 , observa-se para as misturas com $40 \%$ de resíduo compostas pelo solo arenoso laterítico (LA') o mesmo comportamento observado para as misturas constituídas pelos demais solos com a adição ou aumento do teor de cal. Assim, comparando-se os valores de umidade ótima das misturas com $40 \%$ de resíduo constituído pelo solo LA' com a média da $\omega_{0}$ determinada a partir das misturas com os solos argilosos, nota-se uma variação de $63,2 \%, 41,9 \%$ e $26,9 \%$, respectivamente, para os teores de $0 \%$, $5 \%$ e $10 \%$ de cal. Isto mostra que as misturas com o solo arenoso laterítico (LA') apresentam uma variação da $\omega_{0}$ com a adição da cal maior que as observadas nas misturas constituídas pelo solo NG' e LG'.

Ainda analisando a Figura 4.10, observa-se, quando se comparam as umidades ótimas das diversas misturas, que as $\omega_{0}$ das misturas com o solo LA' mostram-se menores do que os valores correspondentes das misturas com os solos NG' e LG', fato que pode ser atribuído à granulometria do solo LA', que possui um teor de finos $(27 \%)$ significativamente menor quando comparado ao teor de finos dos solos NG' (83\%) e LG' (75\%). 
Portanto, com base nas análises da umidade ótima das diversas composições estudadas (conforme Tabela 4.2), pode-se concluir, conforme já constatado nas análises da massa especifica seca máxima, que o comportamento laterítico, analisado entre os solos NG' e LG', influencia pouco a variação da umidade ótima com o acréscimo de resíduo e com a variação do teor de cal. Da mesma forma como demonstrado para a variação da $\rho_{d m a x}$, as misturas constituídas com o solo LA' apresentaram um comportamento diferenciado quanto à variação da umidade ótima, o que também evidencia que, o fator preponderante na variação da $\omega_{\circ}$ é a granulometria, se comparado com a influência da gênese do material.

\subsection{PROPRIEDADES MECÂNICAS DAS MISTURAS}

Os resultados aqui descritos referem-se inicialmente aos ensaios de compressão simples, posteriormente analisar-se-ão os ensaios de tração indireta e triaxial cíclico.

\subsubsection{Ensaio de compressão simples}

A resistência à compressão simples (RCS) é um dos parâmetros mais utilizados em pavimentação para se avaliar a adequabilidade de misturas estabilizadas para a construção de bases e sub-bases rodoviárias. A diferença de resistência à compressão simples entre a mistura sem cal e a mistura com cal tem sido utilizada como um indicador para determinar se o solo é ou não reativo à cal. Ganhos substanciais de resistência indicam que o solo é reativo e provavelmente produzirá um material de pavimentação de qualidade.

No Brasil, não há uma norma específica para a análise da resistência à compressão simples de solos estabilizados com cal para fins rodoviários, entretanto, pode-se fazer uma comparação segundo os procedimentos de Thompson estabelecidos em Illinois, apresentados na State of the art 5 - Lime Stabilization (TRB, 1987). Estes pesquisadores 
concluíram que um solo estabilizado com $3 \%$ de cal deve apresentar um aumento de resistência à compressão simples superior a $350 \mathrm{kPa}$ em relação ao solo natural para o mesmo ser considerado como reativo à cal. Além de serem reativas, após 28 dias de cura a $22^{\circ} \mathrm{C}$, as misturas independente do teor de cal devem apresentar resistências mínimas de $1000 \mathrm{kPa}$ e $700 \mathrm{kPa}$, para a construção de camadas de bases e sub-bases, respectivamente.

Nos itens seguintes, inicialmente será analisado o comportamento das misturas sob o ponto de vista da resistência e em seguida do ponto de vista da deformabilidade. Numa primeira etapa, os corpos-de-prova foram ensaiados apenas com misturas de solo e resíduo. Esta etapa inicial foi realizada com o objetivo de se determinar o teor máximo de resíduo que permitisse a trabalhabilidade durante os ensaios de compactação, conforme já detalhado anteriormente. Posteriormente, após a definição do teor máximo de resíduo, foram ensaiadas misturas de solo, resíduo e teores variados de cal, sem cura e após 7 dias de cura. Finalmente, fixado o teor de resíduo, foi escolhido o teor de cal que conduziu à maior resistência aos 7 dias de cura para se analisar a influência dos tempos de cura complementares de 2, 28 e 84 dias.

\subsubsection{Resistência à compressão simples imediata}

\subsection{Solo-Resíduo}

Como descrito no Ítem 4.2.1, foram realizados ensaios de compactação variando-se o teor de resíduo com o objetivo de verificar a quantidade máxima deste material que permitiria a trabalhabilidade durante este ensaio. Nesta etapa, foram ensaiados apenas os solos argilosos de comportamento laterítico (LG') e o não-laterítico (NG').

A Tabela 4.3 apresenta as resistências à compressão simples imediatas e sem cura das misturas obtidas com os corpos-de-prova nos teores $40 \%, 45 \%$ e $50 \%$ de resíduo. A 
Figura 4.11 ilustra a variação da resistência à compressão simples com o teor de resíduo das misturas constituídas pelos solos NG' e LG'.

Tabela 4.3 - Resistência à compressão simples sem cura das misturas solo-resíduo

\begin{tabular}{cccccc}
\hline & Misturas & & & \multicolumn{2}{c}{ Resistência (kPa) } \\
\cline { 1 - 2 } \cline { 5 - 6 } Solo (\%) & Resíduo (\%) & Cal (\%) & & Solo NG' & Solo LG' \\
\hline 60 & 40 & 0 & & 210 & 205 \\
55 & 45 & 0 & & 195 & 183 \\
50 & 50 & 0 & & 182 & 170 \\
\hline
\end{tabular}

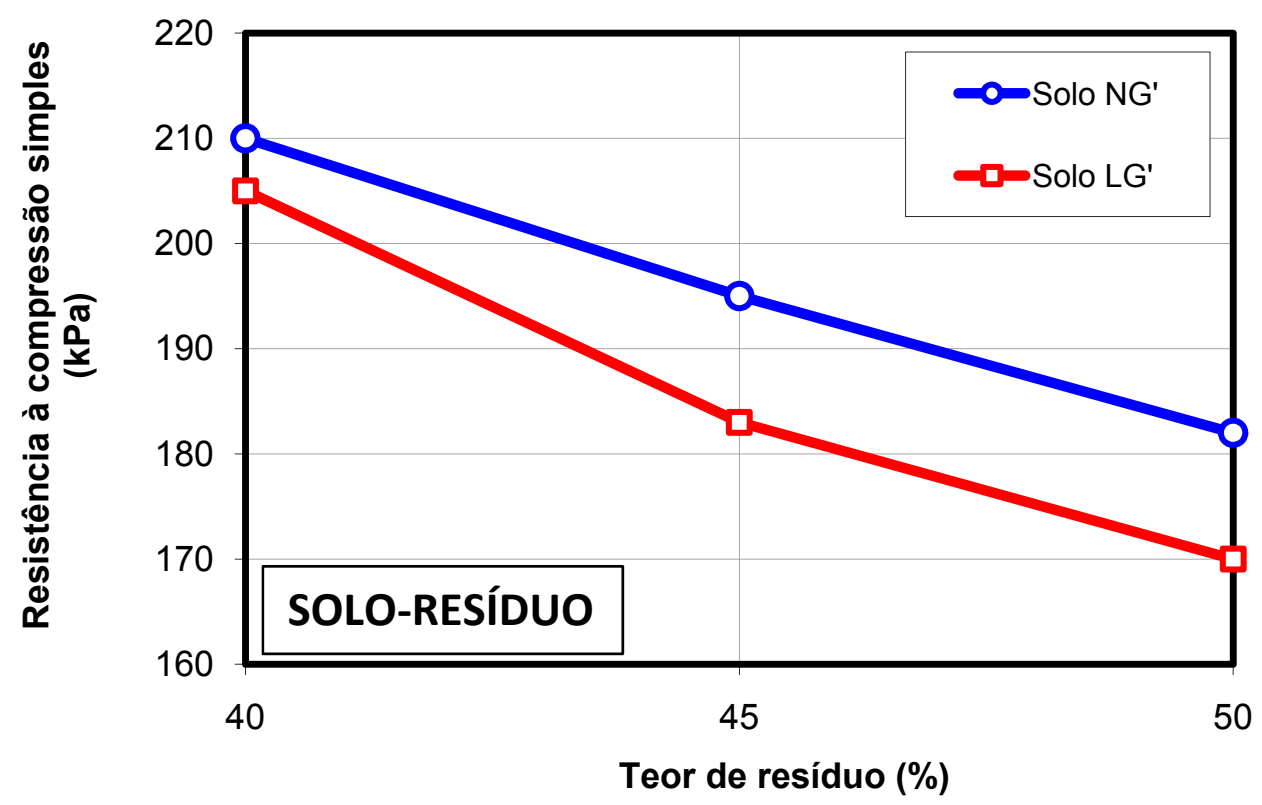

Figura 4.11 - Variação da resistência à compressão simples sem cura com o teor de resíduo para o solo argiloso não-laterítico (NG') e argiloso laterítico (LG')

Analisando-se os valores apresentados na Tabela 4.3 e conforme ilustrado na Figura 4.11, observa-se uma diminuição da resistência à compressão simples com o aumento do teor de resíduo para ambos os solos, e que as misturas constituídas com o solo NG' apresentam resistências à compressão simples superiores às das misturas com o solo LG', para iguais teores de resíduo.

A diminuição da RCS com o aumento do teor de resíduo poderia ser explicada pela contribuição do próprio aumento de resíduo, material com baixa resistência, e também pelo 
fato de teores superiores a $40 \%$ de resíduo acarretarem problemas durante a compactação dos corpos-de-prova, conforme já descrito no Ítem 4.2.1. Assim, conforme descrito no Ítem 3.4 do Capítulo 3, os resultados destes ensaios confirmam o teor máximo alcançado de $40 \%$ de resíduo para a composição das misturas. Desta forma, os demais ensaios serão realizados com este teor de resíduo.

\subsection{Solo-Resíduo-Cal e Solo-Cal}

Conforme descrito anteriormente, após a definição do teor máximo de resíduo a ser utilizado na composição das misturas, os corpos-de-prova constituídos pelos solos NG' e LG', sem resíduo e com $40 \%$ de resíduo, e estabilizadas com cal, foram submetidas a ensaios de compressão simples imediatamente após a compactação, ou seja, sem cura. O solo LA' não foi incluído nesta etapa do estudo.

A Tabela 4.4 apresenta os valores das resistências à compressão simples sem cura para todas as misturas estudadas e o ganho relativo de resistência das misturas com a adição de $5 \%$ e $10 \%$ de cal. Este ganho foi calculado com relação à resistência dos solos sem a adição de cal. As Figuras 4.12 e 4.13 ilustram a variação da resistência à compressão simples com o teor de resíduo e cal, para as misturas solo-cal e solo-resíduo-cal, respectivamente.

Tabela 4.4 - Resistência à compressão simples sem cura dos solos, misturas solo-cal, misturas solo-resíduo e misturas solo-resíduo-cal

\begin{tabular}{|c|c|c|c|c|c|}
\hline Tipo de solo & $\begin{array}{c}\text { Teor de } \\
\text { Resíduo } \\
\text { (\%) }\end{array}$ & $\begin{array}{c}\text { Teor de } \\
\text { cal } \\
(\%)\end{array}$ & $\begin{array}{l}\text { Resistência à } \\
\text { compressão } \\
\text { simples } \\
(\mathrm{kPa})\end{array}$ & $\begin{array}{l}\text { Diferença } \\
\text { (kPa) }\end{array}$ & $\begin{array}{c}\text { Ganho } \\
(\%)\end{array}$ \\
\hline \multirow{6}{*}{ LG' } & \multirow{3}{*}{0} & 0 & 258 & & \\
\hline & & 5 & 420 & 162 & 63 \\
\hline & & 10 & 407 & 149 & 58 \\
\hline & \multirow{3}{*}{40} & 0 & 205 & & \\
\hline & & 5 & 250 & 45 & 22 \\
\hline & & 10 & 290 & 85 & 41 \\
\hline
\end{tabular}




\begin{tabular}{cccccc}
\hline \multirow{3}{*}{$N G^{\prime}$} & & 0 & 333 & & \\
& 0 & 5 & 286 & -47 & -14 \\
& & 10 & 329 & -4 & -1 \\
\cline { 2 - 6 } & & 0 & 210 & & \\
& 40 & 5 & 305 & 95 & 45 \\
& 10 & 350 & 140 & 67 \\
\hline
\end{tabular}

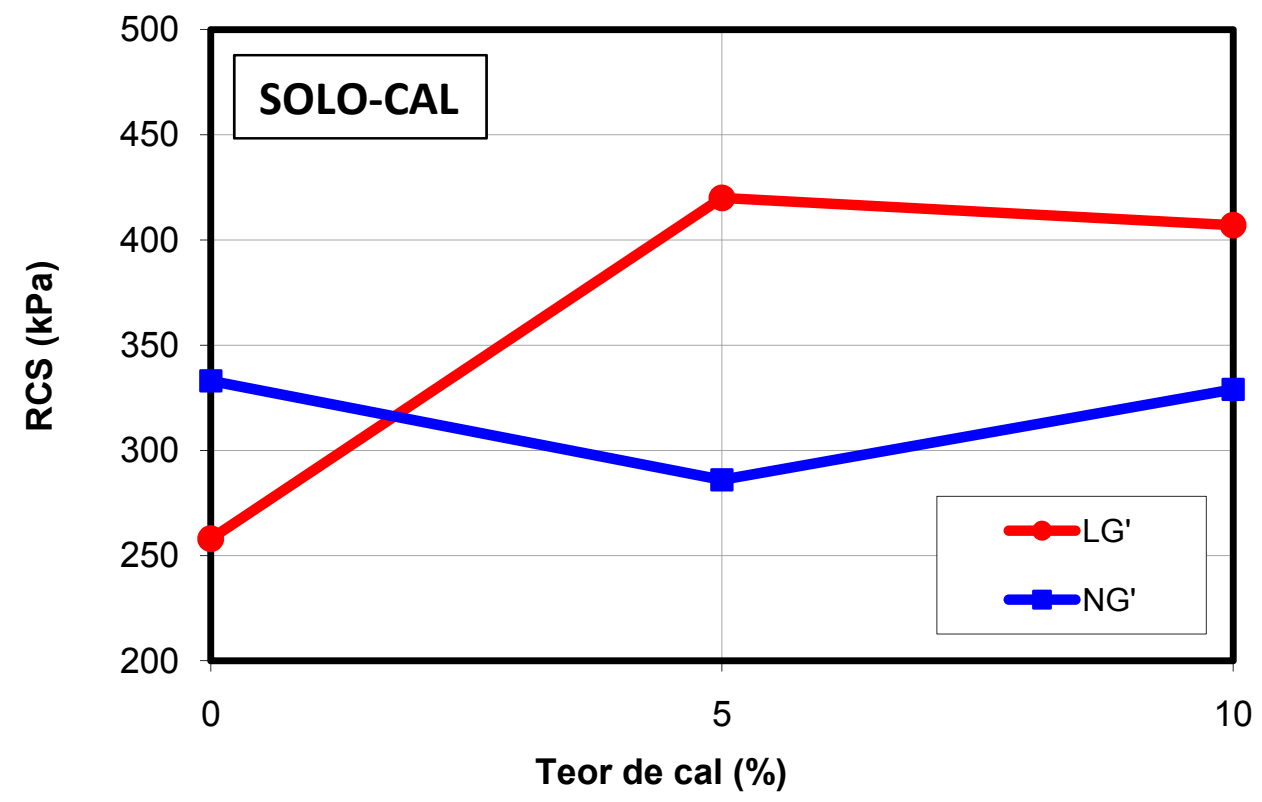

Figura 4.12 - Variação da resistência à compressão simples sem cura com os teores de cal para as misturas de solos NG' e LG'

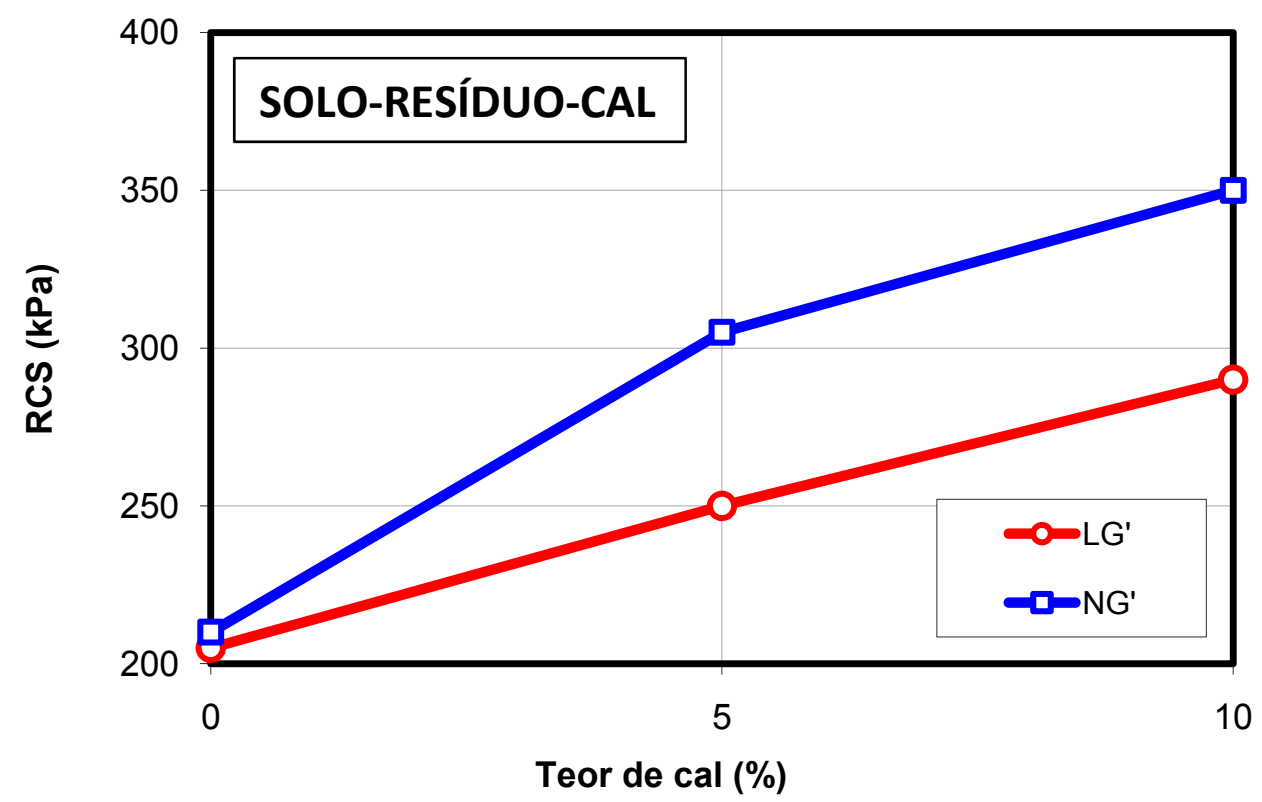

Figura 4.13 - Variação da resistência à compressão simples sem cura com os teores de cal para as misturas de solos NG' e LG' com resíduo 
Analisando a Tabela 4.4 e conforme a ilustração da Figura 4.12, quanto aos solos naturais, observa-se que o solo NG' apresenta uma resistência 29\% superior ao solo LG', contrariando às expectativas de o solo laterítico apresentar uma resistência superior à do solo não-laterítico. Portanto, supõe-se que neste caso, a influência da granulometria sobrepôs-se a da gênese, visto que o solo NG' apresenta uma granulometria "mais grossa" que a do solo LG', conduzindo a uma resistência mais elevada. Outro aspecto observado é que para as misturas solo-cal, o solo LG' apresenta em média, para os dois teores, uma resistência 40\% superior ao do solo NG'. Ao se analisar o solo NG', observa-se que ao se variar o teor de cal de 0 para $5 \%$ ocorre uma diminuição da RCS de $14 \%$. Para $10 \%$ de cal, ocorre um aumento de resistência, mas não se alcança a resistência do solo sem a adição da cal.

No tocante às misturas solo-resíduo-cal, Figura 4.13, observa-se que as misturas solo-resíduo sem cal apresentam resistências próximas entre si, ligeiramente favorável à mistura composta com o solo NG'. Observa-se, também, quanto ao efeito da adição da cal, que as misturas compostas pelo solo NG' apresentam uma resistência média, para os dois teores de cal, $21 \%$ superior à resistência média das misturas solo-resíduo-cal compostas pelo solo LG'. Ainda observa-se para ambos os solos, que a adição acarreta um aumento da resistência.

Finalmente, comparando-se a RCS das misturas solo-cal e solo-resíduo-cal, observa-se que para as misturas sem a adição da cal, o resíduo atua como um agente redutor da resistência, ocorrendo uma redução na RCS de $21 \%$ e $37 \%$ para os solos LG' e NG', respectivamente. Para as misturas com cal, considerando as resistências médias calculadas a partir dos dois teores, a mistura solo-cal apresenta resistência inferior em $6 \%$ à da mistura solo-resíduo-cal para o solo NG', sendo que para o solo LG', ocorre uma inversão e a mistura solo-cal apresenta resistência $21 \%$ superior à da mistura solo-resíduocal. 
Conclui-se que para os ensaios sem cura, as misturas constituídas com o solo LG' demonstram melhor comportamento com relação às constituídas com o solo NG' quando não há adição de resíduo. Entretanto, quando há adição de resíduo, há uma inversão e as misturas constituídas pelo solo NG' apresentam melhor comportamento com relação às constituídas pelo solo LG'.

Destaca-se que os resultados de resistência imediata aqui apresentados têm caráter ilustrativo e foram utilizados como medidas de comparação entre o comportamento das diversas misturas. A sua utilização em conjunto com os demais ensaios deve ser feita com reserva, visto que o controle dos mesmos não foi rigoroso, pois não houve repetições de ensaios.

\subsubsection{Resistência à compressão simples aos 7 dias de cura}

As misturas constituídas pelos solos NG' e LG', sem resíduo e com $40 \%$ de resíduo, e estabilizadas com $0 \%, 5 \%$ e $10 \%$ de cal foram submetidas ao ensaio de compressão simples com cura de 7 dias. Para as misturas com o solo LA', foram realizados ensaios apenas com as misturas constituídas com $40 \%$ de resíduo e estabilizadas com $0 \%, 5 \%$ e $10 \%$ de cal. Os ensaios foram realizados observando-se os procedimentos descritos no Item 3.5.1 do Capítulo 3.

A Tabela 4.5 apresenta os valores de resistências à compressão simples aos 7 dias de cura para todas as misturas estudadas. O ganho relativo de resistência das misturas com a adição de $5 \%$ e $10 \%$ de cal foi calculado com relação à resistência sem a adição de cal.

As Figuras 4.14 e 4.15 ilustram, respectivamente, as variações da RCS das misturas solo-cal e solo-resíduo-cal, para o solo arenoso laterítico (LA') e os solos argilosos de comportamento laterítico (LG') e não-laterítico (NG'). 
Tabela 4.5 - Resistência à compressão simples para as misturas solo-cal, solo-resíduo e soloresíduo-cal

\begin{tabular}{|c|c|c|c|c|c|}
\hline Tipo de solo & $\begin{array}{c}\text { Teor de } \\
\text { Resíduo } \\
(\%) \\
\end{array}$ & $\begin{array}{l}\text { Teor de } \\
\text { cal (\%) }\end{array}$ & $\begin{array}{c}\text { Resistência à } \\
\text { compressão } \\
\text { simples (kPa) }\end{array}$ & $\begin{array}{l}\text { Diferença } \\
(\mathrm{kPa})\end{array}$ & $\begin{array}{c}\text { Ganho } \\
(\%)\end{array}$ \\
\hline \multirow{6}{*}{ LG' } & \multirow{3}{*}{0} & 0 & 258 & & \\
\hline & & 5 & 794 & 535 & 207 \\
\hline & & 10 & 1136 & 877 & 338 \\
\hline & \multirow{3}{*}{40} & 0 & 214 & & \\
\hline & & 5 & 431 & 217 & 101 \\
\hline & & 10 & 697 & 484 & 226 \\
\hline \multirow{6}{*}{ NG' } & \multirow{3}{*}{0} & 0 & 333 & & \\
\hline & & 5 & 649 & 310 & 91 \\
\hline & & 10 & 1547 & 1208 & 356 \\
\hline & \multirow{3}{*}{40} & 0 & 162 & & \\
\hline & & 5 & 416 & 254 & 157 \\
\hline & & 10 & 774 & 612 & 379 \\
\hline \multirow{3}{*}{ LA' $^{\prime}$} & \multirow{3}{*}{40} & 0 & 147 & & \\
\hline & & 5 & 234 & 87 & 59 \\
\hline & & 10 & 215 & 68 & 46 \\
\hline
\end{tabular}

Nota: Tempo de cura de 7 dias

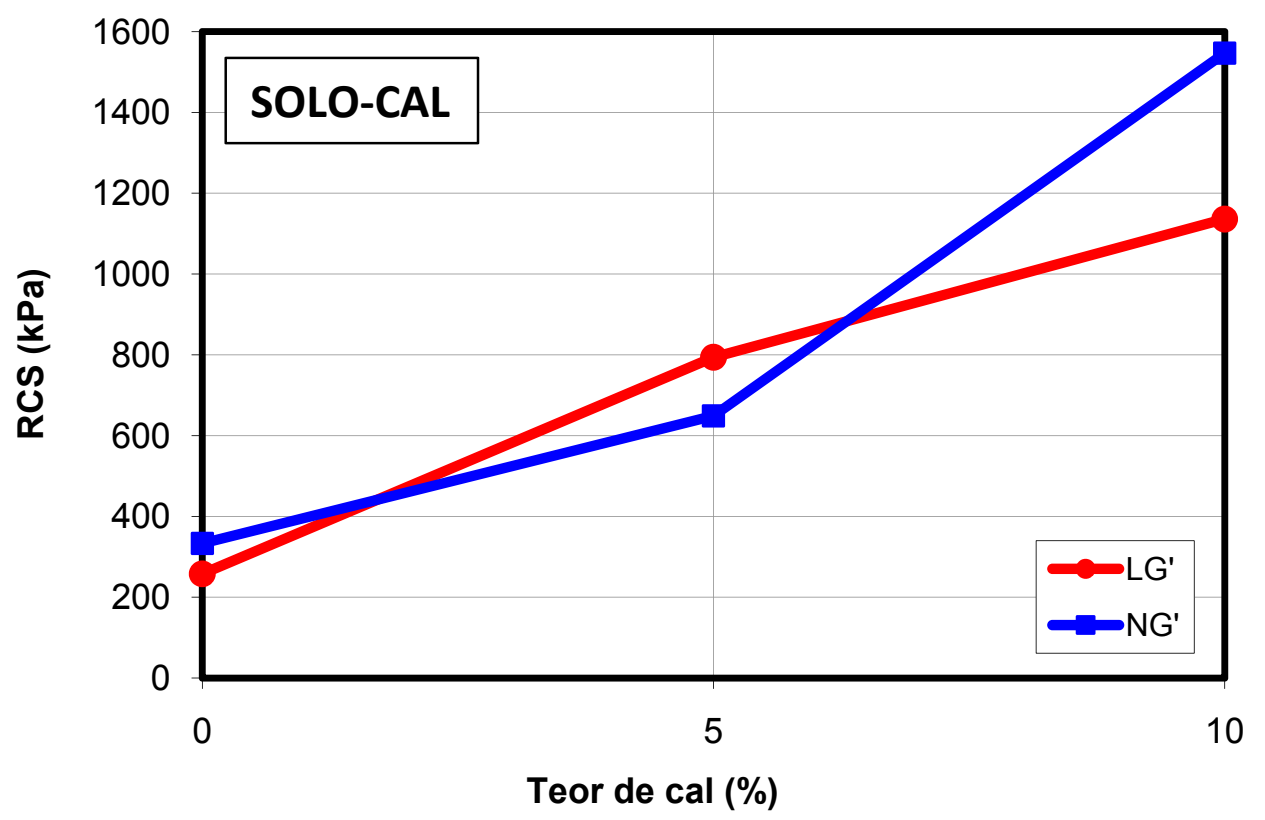

Figura 4.14 - Resistência à compressão simples aos 7 dias de cura para as misturas com o solo NG' e LG' 


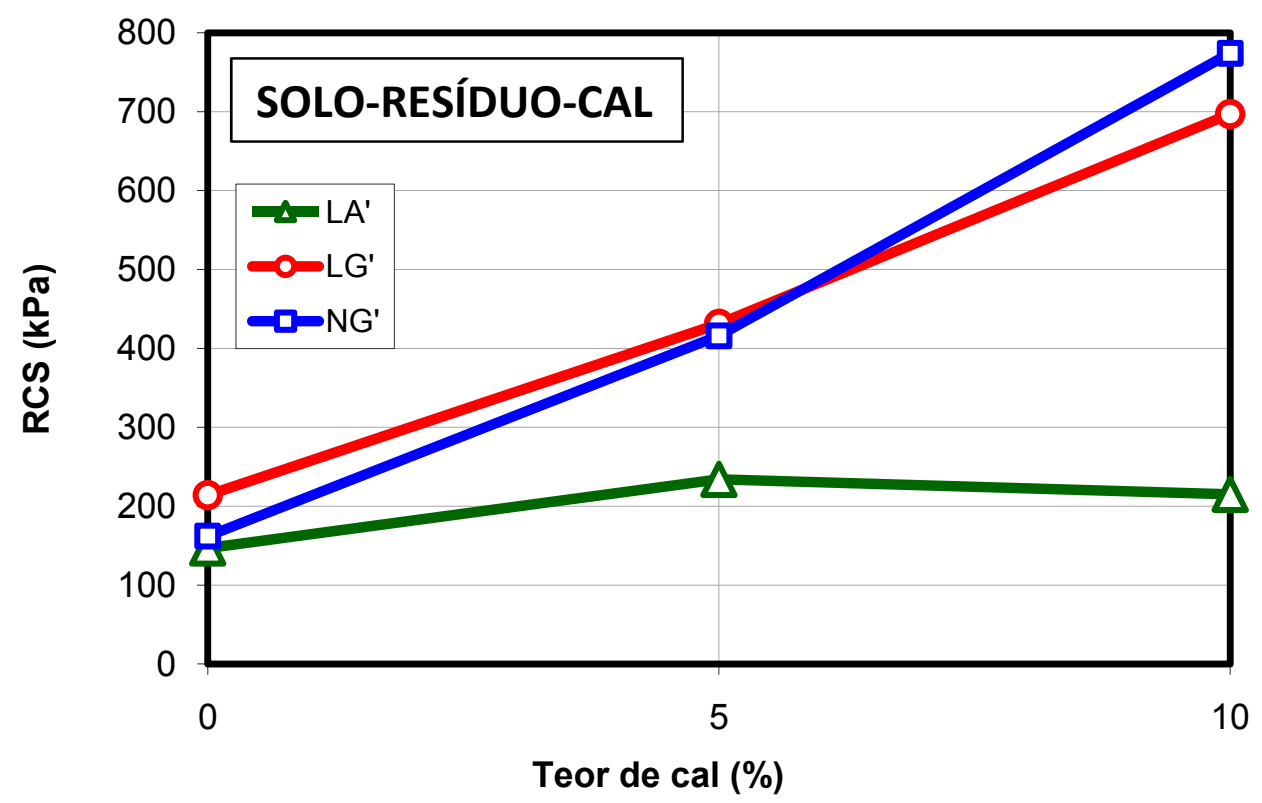

Figura 4.15 - Resistência à compressão simples aos 7 dias de cura das misturas com o solo NG', LG', LA' e o resíduo

Analisando-se os valores apresentados na Tabela 4.5 e a ilustração da Figura 4.14, observa-se que os solos LG' e NG' apresentam resistências próximas entre si, ligeiramente favorável à mistura composta com o solo NG'. Observa-se, ainda, que o acréscimo de cal conduz ao aumento da RCS para ambos os solos. Considerando-se a média calculada para os dois solos e calculando-se o acréscimo de resistência devido à cal com relação à resistência do solo natural, conclui-se que existe um ganho de resistência de $149 \%$ e $347 \%$, respectivamente para $5 \%$ e $10 \%$ de cal. Entretanto, este comportamento não foi observado para as mesmas misturas ensaiadas imediatamente após a compactação, fato este que pode ser explicado pelo tempo insuficiente para o desenvolvimento adequado das reações pozolânicas entre o solo e a cal acontecerem. Comportamento semelhante já foi revelado para solos estabilizados com cal por diversos autores (GUIMARÃES, 1971; CASTRO et al, 1974; MENDONÇA et al, 1997, etc).

Ainda na Figura 4.14, no tocante à influência da cal no comportamento mecânico dos solos, é sabido, de maneira geral, que os materiais mais finos são mais afeitos à sua ação, da mesma maneira que os solos não-lateríticos. Assim, para o teor de $5 \%$, supõe-se que o 
efeito da granulometria seja maior que a da gênese, tendo em vista que o solo LG', "mais fino", apresenta uma resistência $22 \%$ superior à do solo NG'. Para o teor de $10 \%$ de cal, observa-se uma inversão, ou seja, a resistência do solo NG' é $36 \%$ superior à do solo LG', indicando que para maiores teores do aditivo, a influência da gênese passa a ser predominante frente à influência da granulometria. Finalmente, destaca-se o crescimento pronunciado da RCS do solo NG' quando se aumenta o teor de cal de $5 \%$ para $10 \%$ ao se comparar ao comportamento do solo LG' nas mesmas condições.

No tocante às misturas com $40 \%$ de resíduo constituídas pelos solos LA', NG' e LG', ao se analisar os valores apresentados na Tabela 4.5 e a ilustração da Figura 4.15, observase que, o acréscimo de cal conduz ao aumento da RCS para ambos os solos argilosos, fato que não ocorre para o solo LA'. Para os materiais sem a adição de cal, observa-se que a resistência do solo LG' é superior ao do solo NG' e LA'.

Ainda na Figura 4.15, para 5\% de cal, ao comparar as misturas compostas pelo solo argiloso laterítico e o argiloso não-laterítico, observa-se uma resistência de $3 \%$ favorável à mistura com solo LG', este valor pode ser inclusive considerado da mesma ordem de grandeza da dispersão dos resultados do ensaio. Observa-se ainda, para este teor, que a mistura com o solo LA' apresenta um ganho de 59\% em relação à mistura não estabilizada, seguindo o comportamento esperado, ou seja, o efeito da cal é mais eficaz quando adicionada a solos argilosos. Para as misturas compostas com os solos argilosos, ao se elevar o teor de $5 \%$ para $10 \%$ de cal houve uma inversão, ou seja, a resistência do solo NG' foi de $11 \%$ superior à do solo LG', indicando que para maiores teores do aditivo, a influência da gênese passa a ser predominante frente à influência da granulometria. Pôde-se observar também que houve uma redução de $8 \%$ da RCS para o solo LA' no mesmo intervalo de variação do teor de cal, indicando que para misturas solo-resíduo-cal compostas com solo arenoso, o aumento da cal não tem um efeito positivo e o teor ótimo é próximo dos $5 \%$, conforme já observado por Molina (2004), para solos granulares. 
Finalmente, comparando-se os solos NG' e LG' sem resíduo em relação às misturas com a adição do resíduo, observa-se que a ação do resíduo agiu como um redutor da RCS. Entretanto, todas as misturas de solo-resíduo estabilizadas com cal, adquiriram resistências superiores quando comparadas às mesmas não estabilizadas. Para as misturas de solo-cal, as RCS são superiores em relação às misturas de solo-resíduo-cal em média $87 \%$ e $63 \%$ respectivamente para os solos NG' e LG'. Apesar da redução das resistências obtidas das misturas de solo-resíduo-cal, as mesmas são promissoras para a utilização em camadas de base, quando adicionados $10 \%$ de cal, e para camadas de sub-base, quando adicionados $5 \%$ de cal. Segundo dados apresentados na State of the art 5 - Lime stabilization (TRB, 1987), pode-se considerar que tanto as misturas solo-cal como as misturas solo-resíduo-cal, com $10 \%$ de cal, são misturas reativas à ação da cal, visto que apresentou um incremento de resistência superior a $345 \mathrm{kPa}$ quando comparados com os solos naturais.

\subsubsection{Influência do tempo de cura na compressão simples}

O estudo da influência do tempo de cura permite avaliar o efeito das reações físicoquímicas e as reações pozolânicas que ocorrem sobre as misturas devido à adição da cal. O estudo para os solos NG' e LG', foi feito para a porcentagem de $10 \%$ de cal, que corresponde ao teor que proporcionou os maiores valores de RCS, e para os teores de 0 e $40 \%$ de resíduo. Os tempos de cura considerados foram de 0, 2, 7, 28 e 84 dias em câmara úmida.

$\mathrm{Na}$ Tabela 4.6 são apresentados os valores da RCS nas misturas solo-cal e soloresíduo-cal com a variação do tempo de cura para misturas com o teor de $10 \%$ de cal. A diferença e o ganho relativo de resistência das misturas com o aumento do tempo de cura foram calculados com relação à resistência imediata. As Figuras 4.16 e 4.17 ilustram, respectivamente, para as misturas solo-cal e solo-resíduo-cal, a variação da resistência à compressão simples das misturas em função do tempo de cura e da adição do resíduo para 
corpos-de-prova ensaiados sem imersão prévia em água. Observa-se que o aumento do tempo de cura conduz ao aumento da RCS para ambos os solos e misturas, e que este aumento tem um crescimento acentuado no período inicial de 7 dias, destacando-se de forma mais favorável para o solo NG'.

Tabela 4.6 - Resistência à compressão simples das misturas de solo-resíduo-cal e solo-cal para os tempos de cura de $0,2,7,28$ e 84 dias

\begin{tabular}{|c|c|c|c|c|c|}
\hline Tipo de solo & $\begin{array}{c}\text { Teor de } \\
\text { Resíduo } \\
(\%)\end{array}$ & $\begin{array}{l}\text { Tempo de } \\
\text { Cura } \\
\text { (dias) }\end{array}$ & $\begin{array}{c}\text { Resistência à } \\
\text { compressão } \\
\text { simples (kPa) }\end{array}$ & $\begin{array}{l}\text { Diferença } \\
\quad(\mathrm{kPa})\end{array}$ & $\begin{array}{c}\text { Ganho } \\
(\%)\end{array}$ \\
\hline \multirow{10}{*}{ LG' } & \multirow{5}{*}{0} & 0 & 407 & & \\
\hline & & 2 & 859 & 452 & 111 \\
\hline & & 7 & 1136 & 729 & 179 \\
\hline & & 28 & 1168 & 761 & 187 \\
\hline & & 84 & 1195 & 788 & 194 \\
\hline & \multirow{5}{*}{40} & 0 & 290 & & \\
\hline & & 2 & 521 & 231 & 80 \\
\hline & & 7 & 697 & 407 & 140 \\
\hline & & 28 & 719 & 429 & 148 \\
\hline & & 84 & 802 & 512 & 177 \\
\hline \multirow{10}{*}{ NG' } & \multirow{5}{*}{0} & 0 & 329 & & \\
\hline & & 2 & 743 & 414 & 126 \\
\hline & & 7 & 1547 & 1218 & 370 \\
\hline & & 28 & 2419 & 2090 & 635 \\
\hline & & 84 & 2806 & 2477 & 753 \\
\hline & \multirow{5}{*}{40} & 0 & 350 & & \\
\hline & & 2 & 585 & 235 & 67 \\
\hline & & 7 & 774 & 424 & 121 \\
\hline & & 28 & 1165 & 815 & 233 \\
\hline & & 84 & 1319 & 969 & 277 \\
\hline
\end{tabular}

Nota: Teor de Cal $10 \%$ 


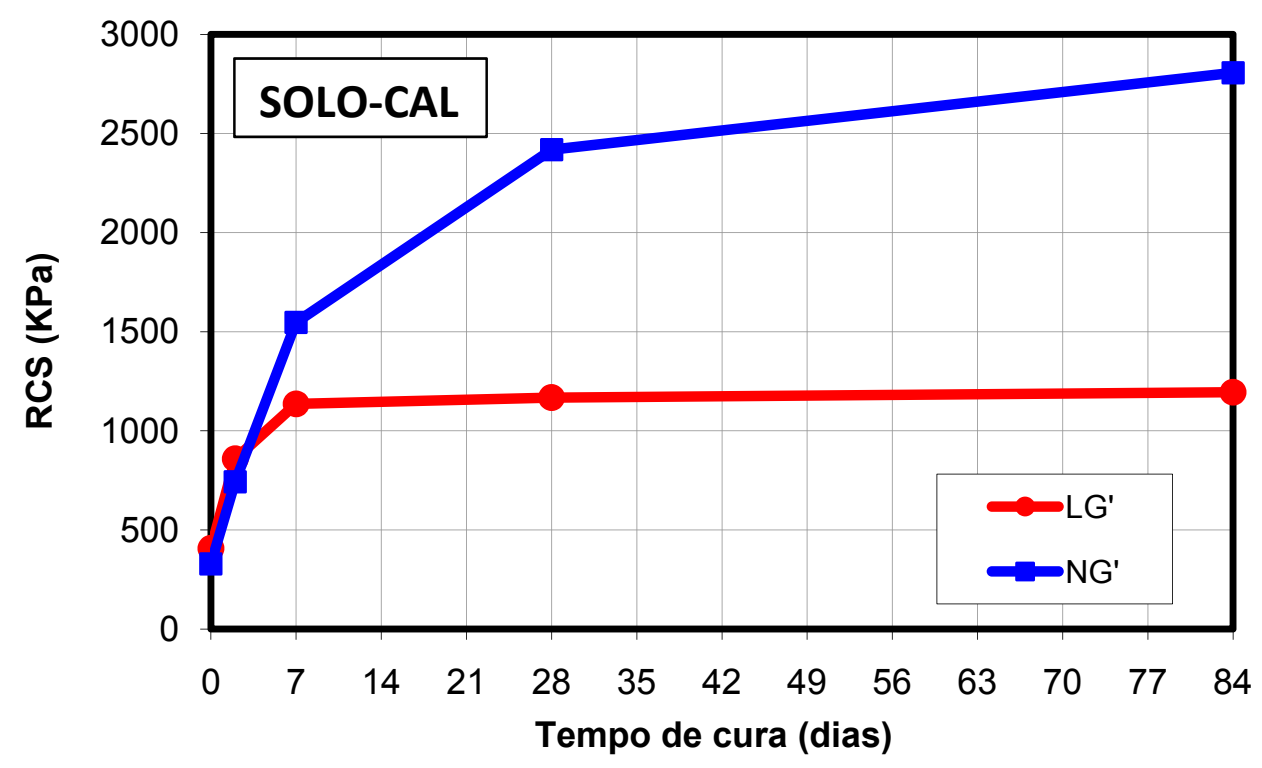

Figura 4.16 - Variação da RCS do solo laterítico (LG') e não-laterítico (NG') com o tempo de cura para misturas com $10 \%$ de cal

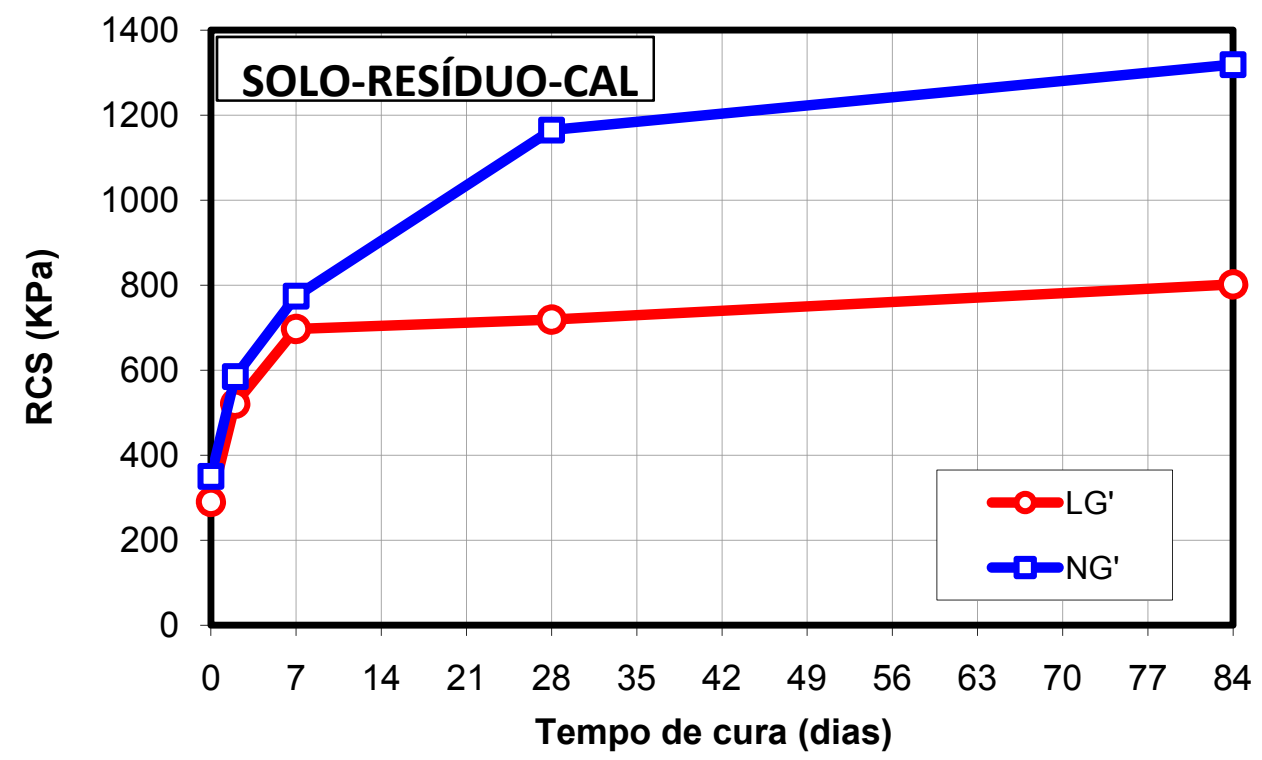

Figura 4.17 - Variação da RCS com o tempo de cura da mistura de resíduo com o solo laterítico (LG') e não-laterítico (NG') para misturas com $10 \%$ de cal

Analisando-se a Figura 4.16, no tocante à influência da gênese dos materiais sem a adição de resíduo, nota-se que a RCS do solo LG' mantêm-se estabilizada após os 7 dias de cura, enquanto para o solo NG', a taxa da variação da resistência torna-se cada vez menor, mas ainda mostra um gradiente crescente aos 84 dias de cura, não indicando uma estabilização. 
Ainda na Figura 4.16, observa-se que os ganhos de resistência, apresentados na Tabela 4.6, com relação à RCS dos corpos-de-prova dos solos LG' e NG' ensaiados sem cura, mostram que estes valores do ganho de resistência para o solo NG' dá-se de maneira efetiva durante um período mais longo que o correspondente ao solo LG'.

Ao se compararem as resistências das misturas constituídas pelos solos LG' e NG' ao longo do período de cura, observa-se que aos 2 dias, os valores são próximos entre si, mas favoráveis ao solo laterítico. Aos 7 dias de cura, ocorre uma inversão e a mistura com o solo NG' apresenta resistência superior à do solo LG'. Aos 84 dias, a diferença é de 1.610 kPa favorável ao solo não-laterítico, para ensaios sem imersão, indicando que este solo é mais reativo à cal que o solo laterítico.

Analisando-se a Figura 4.17, para misturas solo-resíduo-cal, no tocante à influência da gênese dos materiais, nota-se que a RCS do solo LG' mantêm-se estabilizada após os 7 dias de cura, repetindo o mesmo comportamento verificado sem a adição do resíduo, enquanto para o solo NG', a taxa da variação da resistência torna-se cada vez menor, mas ainda mostra um gradiente crescente aos 84 dias de cura, não indicando uma estabilização.

Ainda na Figura 4.17, observou-se um ganho de resistência, apresentados na Tabela 4.6, com relação à RCS dos corpos-de-prova dos solos LG' e NG' ensaiados sem cura, mostram que estes valores do ganho de resistência para o solo NG' dá-se de maneira efetiva durante um período mais longo que o correspondente ao solo LG'.

Ao se compararem as resistências das misturas constituídas pelos solos LG' e NG' ao longo do período de cura, observa-se que aos 7 dias, os valores são próximos entre si, favoráveis ao solo não-laterítico. Após os 7 dias de cura o solo NG' continua crescente. Aos 84 dias, a diferença é de 517 kPa favorável ao solo não-laterítico. 
Quando se analisam as resistências das misturas de solo-resíduo-cal em relação às misturas de solo-cal ao longo do período de cura, observa-se que a adição do resíduo provocou uma redução, em média, da resistência para todos os tempos de cura, de $44 \%$ e $37 \%$ respectivamente, para os solos NG' e LG'.

Finalmente, conclui-se que as misturas de solo-cal, constituídas com $10 \%$ de cal, enquadram-se, como material para base e sub-base de pavimentos, de acordo com as resistências às compressões simples mínimas estabelecidas segundo o procedimento desenvolvido em Illinois apresentados na State of the art 5 - Lime stabilization (TRB, 1987), na qual estabelece que para corpos-de-prova ensaiados com 28 dias de cura, a uma temperatura de $22^{\circ} \mathrm{C}$, os mesmos obtenham resistências mínima de $700 \mathrm{kPa}$ e $1000 \mathrm{kPa}$, respectivamente para camadas de sub-base e base. Para as misturas de solo-resíduo-cal, seguindo o mesmo padrão de análise feita para as misturas de solo-cal, o solo NG' enquadra-se, quanto à RCS mínima, como material para base e sub-base de pavimentos, entretanto o solo LG' obteve resistência apenas para sua utilização como material para subbase de pavimento.

\subsubsection{Influência da imersão em água na resistência à compressão simples}

Com o propósito de analisar a resistência de camadas de base e sub-base de pavimentos submetidas à influência do aumento de umidade, realizaram-se os ensaios de compressão simples em corpos-de-prova previamente submetidos à imersão em água por um período de 24 horas, para todas as misturas curadas por 7 dias.

Na Tabela 4.7 são apresentadas as misturas variando-se o teor de cal e de resíduo, apresentando também as RCS, as diferenças e perdas de resistência decorrentes da imersão dos corpos-de-prova em água. As Figuras 4.18 e 4.19 ilustram, respectivamente, para as misturas solo-cal e solo-resíduo-cal, a variação da resistência à compressão simples 
em função da imersão em água e teor de cal para corpos-de-prova ensaiados com 7 dias de cura. Observa-se que houve uma redução da RCS quando os corpos-de-prova são ensaiados com imersão e considerando os solos sem cal, observa-se, para ambas as gêneses, que os corpos-de-prova desintegraram-se, não permitindo a realização do ensaio.

Tabela 4.7 - RCS e perdas de resistência das misturas de solo-cal e solo-resíduo-cal para corpos-de-prova ensaiados com imersão em relação aos ensaiados sem imersão em água

\begin{tabular}{|c|c|c|c|c|c|c|}
\hline \multirow{2}{*}{ Tipo de solo } & \multirow{2}{*}{$\begin{array}{c}\text { Teor de } \\
\text { Resíduo } \\
(\%)\end{array}$} & \multirow{2}{*}{$\begin{array}{c}\text { Teor } \\
\text { de Cal } \\
(\%)\end{array}$} & \multicolumn{2}{|c|}{$\mathrm{RCS}(\mathrm{kPa})$} & \multirow{2}{*}{$\begin{array}{l}\text { Diferença } \\
\qquad(\mathrm{kPa})\end{array}$} & \multirow{2}{*}{$\begin{array}{c}\text { Perda } \\
(\%)\end{array}$} \\
\hline & & & Sem Imersão & Com Imersão & & \\
\hline \multirow{6}{*}{ LG' } & \multirow{3}{*}{0} & 0 & 259 & 0 & 259 & 100 \\
\hline & & 5 & 794 & 645 & 149 & 19 \\
\hline & & 10 & 1136 & 1036 & 100 & 9 \\
\hline & \multirow{3}{*}{40} & 0 & 214 & 0 & 214 & 100 \\
\hline & & 5 & 431 & 0 & 431 & 100 \\
\hline & & 10 & 697 & 561 & 136 & 20 \\
\hline \multirow{6}{*}{ NG' } & \multirow{3}{*}{0} & 0 & 339 & 0 & 339 & 100 \\
\hline & & 5 & 649 & 417 & 232 & 36 \\
\hline & & 10 & 1547 & 1351 & 196 & 13 \\
\hline & \multirow{3}{*}{40} & 0 & 162 & 0 & 162 & 100 \\
\hline & & 5 & 416 & 195 & 221 & 53 \\
\hline & & 10 & 774 & 517 & 257 & 33 \\
\hline
\end{tabular}

Nota: Tempo de Cura 7 dias

Quanto à influência da variação de umidade na RCS dos solos e misturas estudadas sem a adição de resíduo, a Figura 4.18 permite se compararem as resistências de corposde-prova ensaiados sem imersão e após imersão em água. Analisando-se os valores na Tabela 4.7 e a ilustração da Figura 4.18, observa-se que corpos-de-prova ensaiados após imersão apresentam resistências crescentes com o teor de cal, repetindo o comportamento observado anteriormente para corpos-de-prova ensaiados sem imersão. Para as misturas estabilizadas com cal, observa-se para ambas as gêneses, que os corpos-de-prova ficaram estáveis, não se desintegrando, denotando o efeito positivo da ação da cal frente à imersão dos solos. 


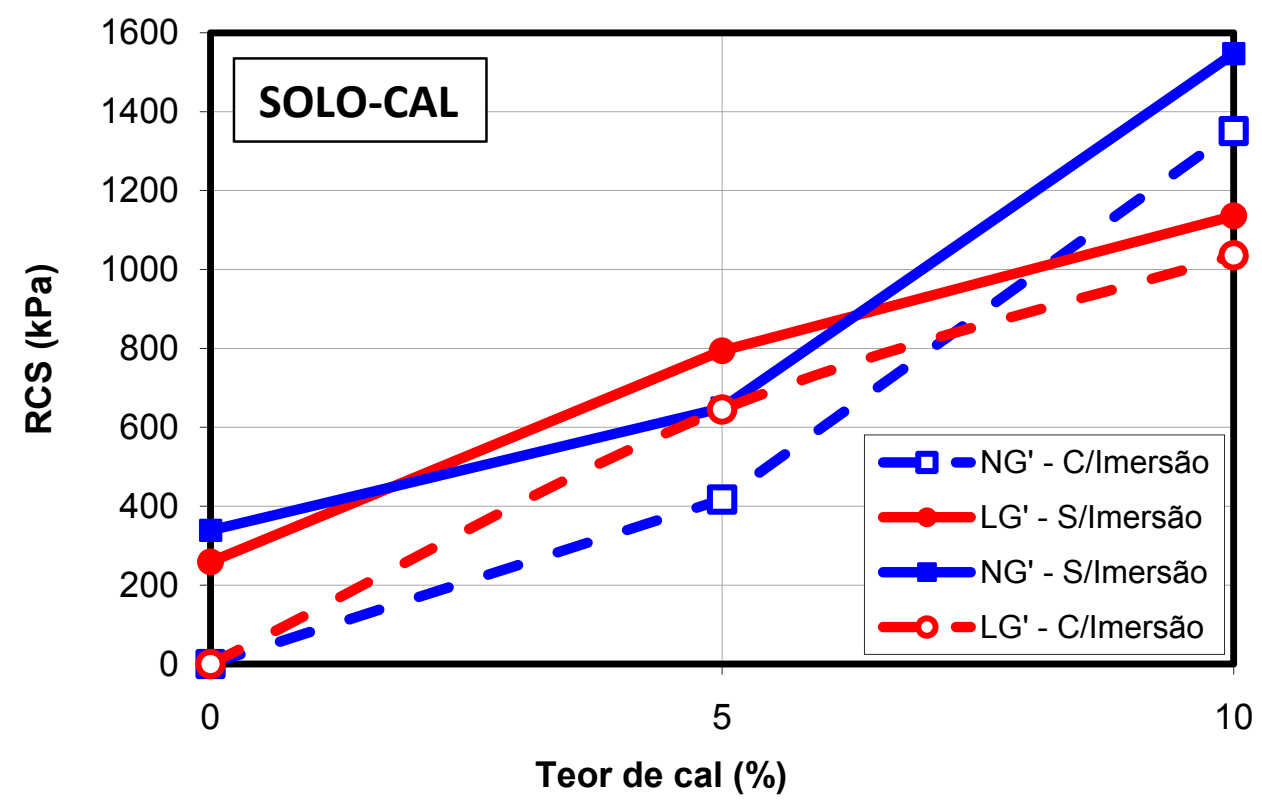

Figura 4.18 - Variação da RCS do solo laterítico (LG') e não-laterítico (NG') com a imersão em água e teor de cal sem adição do resíduo

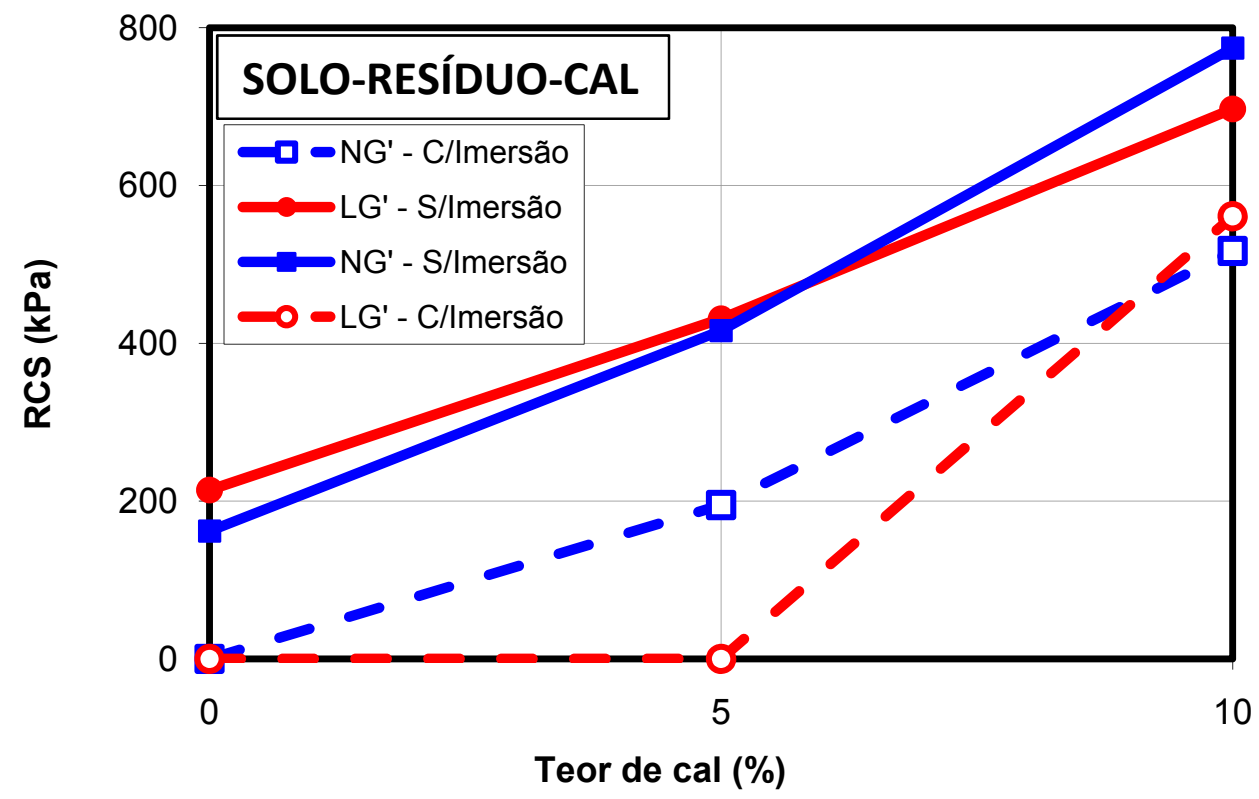

Figura 4.19 - Variação da RCS do solo laterítico (LG') e não-laterítico (NG') com a imersão em água e teor de cal com adição do resíduo

Ainda na Figura 4.18, observa-se que para o teor de $5 \%$ de cal, a perda de resistência devido à imersão é de $19 \%$ e $36 \%$ para os solos LG' e NG', respectivamente. Portanto, para este teor, a menor influência da água sobre o solo laterítico indica que o efeito da gênese sobrepõe-se ao efeito positivo da cal. Para o teor de $10 \%$ de cal, a queda 
de resistência devido à imersão é de $9 \%$ e 13\% para os solos LG' e NG', indicando que o aumento da quantidade de estabilizante contribui para a redução da suscetibilidade das misturas à ação da água, sendo que a influência da gênese age segundo o mesmo padrão observado anteriormente para o teor de $5 \%$.

Quando se analisa a perda de resistência devido à imersão em água, ao se aumentar o teor de cal de $5 \%$ para $10 \%$, observa-se que proporcionalmente, o efeito da cal está na relação 2:1 e 2,8:1, respectivamente para os solos LG' e NG', indicando que para teores mais elevados, a ação da cal é mais efetiva para o solo não-laterítico.

No tocante à influência da variação de umidade na RCS das misturas com a adição de resíduo, a Figura 4.19 permite se compararem as resistências de corpos-de-prova ensaiados sem imersão e após imersão em água. Analisando-se os valores da Tabela 4.7 e a ilustração da Figura 4.19, observa-se que corpos-de-prova ensaiados após imersão apresentam resistência crescente com o teor de cal, exceto para o solo LG' ensaiado com imersão e teor de $5 \%$ de cal. Para as misturas estabilizadas com cal se observa para o solo NG', que os corpos-de-prova ficaram estáveis com o teor de $5 \%$ de cal, para o solo LG' esta estabilização dos corpos-de-prova foi obtida apenas para o teor de $10 \%$ de cal.

Ainda na Figura 4.19, observa-se que para o teor de $5 \%$ de cal, a perda de resistência devido à imersão é de $100 \%$ e 53\% para os solos LG' e NG', respectivamente. Portanto, para este teor, a mistura com o solo NG' é menos susceptível à ação da água. Para o teor de $10 \%$ de cal, a perda de resistência devido à imersão é de $20 \%$ e $33 \%$ respectivamente para os solos LG' e NG', indicando que o aumento da quantidade de estabilizante continua contribuindo para a redução da suscetibilidade das misturas de solo e resíduo à ação da água. 
Quando se analisa a perda de resistência devida à imersão em água, ao se aumentar o teor de cal de $5 \%$ para $10 \%$, observa-se que proporcionalmente, o efeito da cal está na relação 5:1 e 1,6:1, respectivamente para os solos LG' e NG', indicando que a ação da cal nas misturas de solo-resíduo-cal é mais efetiva para o solo laterítico.

Comparando-se o efeito da imersão em água nas misturas solo-cal e solo-resíduocal, observa-se que na RCS as misturas de solo-resíduo-cal são mais susceptíveis à ação da água, para ambos os solos. A perda de resistência das misturas solo-resíduo-cal em relação às misturas solo-cal, considerando as resistências médias calculadas a partir dos dois teores, é de $36 \%$ e $18 \%$ respectivamente para as misturas compostas com os solos LG' e NG'.

\subsubsection{Influência do tempo de cura para misturas ensaiadas após imersão em água na resistência à compressão simples}

Em seguida, para se analisar a influência do aumento da umidade na resistência à compressão simples ao longo do tempo de cura, ensaiou-se misturas solo-cal e soloresíduo-cal com 10\% deste estabilizante, curadas por 0, 2, 7, 28 e 84 dias em câmara úmida e ensaiadas após imersão em água por 24 horas.

Na Tabela 4.8 são apresentados os valores da RCS das misturas de solo-cal e soloresíduo-cal em função da variação do tempo de cura para copos-de-prova ensaiados com imersão e sem imersão em água, com o teor de $10 \%$ de cal. A diferença e a perda relativa de resistência das misturas solo-cal e solo-resíduo-cal ao longo do tempo de cura foram calculadas com relação à resistência imediata. As Figuras 4.20 e 4.21 ilustram, respectivamente, a variação da resistência à compressão simples das misturas solo-cal e solo-resíduo-cal em função do tempo de cura e dos corpos-de-prova ensaiados com imersão prévia em água. Observa-se que, no geral, corpos-de-prova ensaiados após 
imersão em água apresentam um padrão de variação de resistência ao longo do tempo de cura semelhante ao observado anteriormente para as misturas solo-cal e solo-resíduo-cal ensaiadas sem imersão, ou seja, a resistência cresce de maneira mais acentuada no período inicial de 7 dias, destacando-se um maior incremento para as misturas constituídas com o solo NG'.

Tabela 4.8 - Resistência à compressão simples das misturas e a perda de RCS para corpos-deprova ensaiados com imersão e sem imersão em água em função do tempo de cura

\begin{tabular}{|c|c|c|c|c|c|c|}
\hline \multirow{2}{*}{$\begin{array}{l}\text { Tipo de } \\
\text { solo }\end{array}$} & \multirow{2}{*}{$\begin{array}{c}\text { Teor de } \\
\text { Resíduo } \\
\text { (\%) }\end{array}$} & \multirow{2}{*}{$\begin{array}{c}\text { Tempo de } \\
\text { Cura } \\
\text { (Dias) }\end{array}$} & \multicolumn{2}{|c|}{$\mathrm{RCS}(\mathrm{kPa})$} & \multirow{2}{*}{$\begin{array}{l}\text { Diferença } \\
(\mathrm{kPa})\end{array}$} & \multirow{2}{*}{$\begin{array}{c}\text { Perda } \\
(\%)\end{array}$} \\
\hline & & & Sem Imersão & Com Imersão & & \\
\hline \multirow{10}{*}{ LG' } & \multirow{5}{*}{0} & 0 & 407 & 0 & 407 & 100 \\
\hline & & 2 & 859 & 635 & 224 & 26 \\
\hline & & 7 & 1136 & 1036 & 100 & 9 \\
\hline & & 28 & 1168 & 1070 & 98 & 8 \\
\hline & & 84 & 1195 & 1087 & 108 & 9 \\
\hline & \multirow{5}{*}{40} & 0 & 290 & 0 & 290 & 100 \\
\hline & & 2 & 521 & 282 & 239 & 46 \\
\hline & & 7 & 697 & 561 & 136 & 20 \\
\hline & & 28 & 719 & 594 & 125 & 17 \\
\hline & & 84 & 802 & 625 & 178 & 22 \\
\hline \multirow{10}{*}{ NG' } & \multirow{5}{*}{0} & 0 & 329 & 0 & 329 & 100 \\
\hline & & 2 & 743 & 629 & 114 & 15 \\
\hline & & 7 & 1547 & 1351 & 196 & 13 \\
\hline & & 28 & 2419 & 1821 & 598 & 25 \\
\hline & & 84 & 2806 & 2338 & 468 & 17 \\
\hline & \multirow{5}{*}{40} & 0 & 350 & 0 & 350 & 100 \\
\hline & & 2 & 585 & 439 & 146 & 25 \\
\hline & & 7 & 774 & 517 & 257 & 33 \\
\hline & & 28 & 1165 & 801 & 364 & 31 \\
\hline & & 84 & 1319 & 1177 & 142 & 11 \\
\hline
\end{tabular}




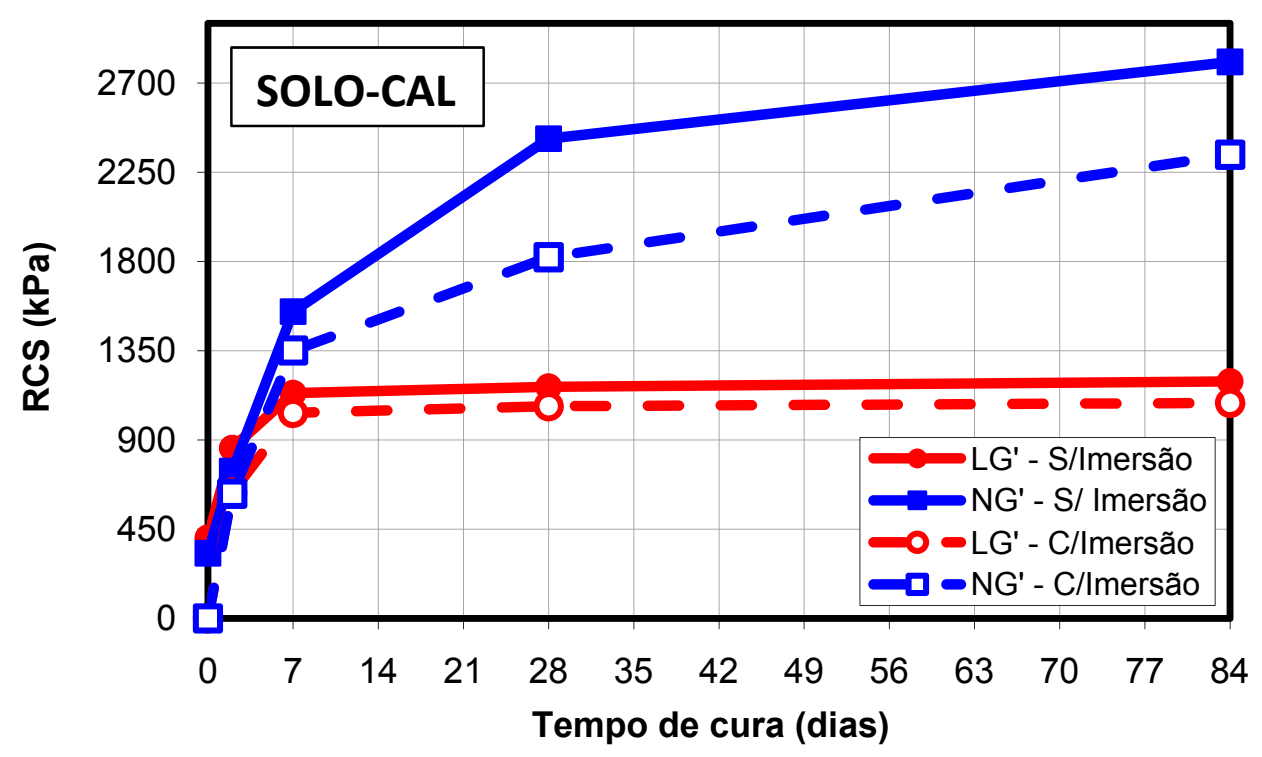

Figura 4.20 - Variação da RCS do solo LG' e NG' com a imersão em água e período de cura sem adição do resíduo

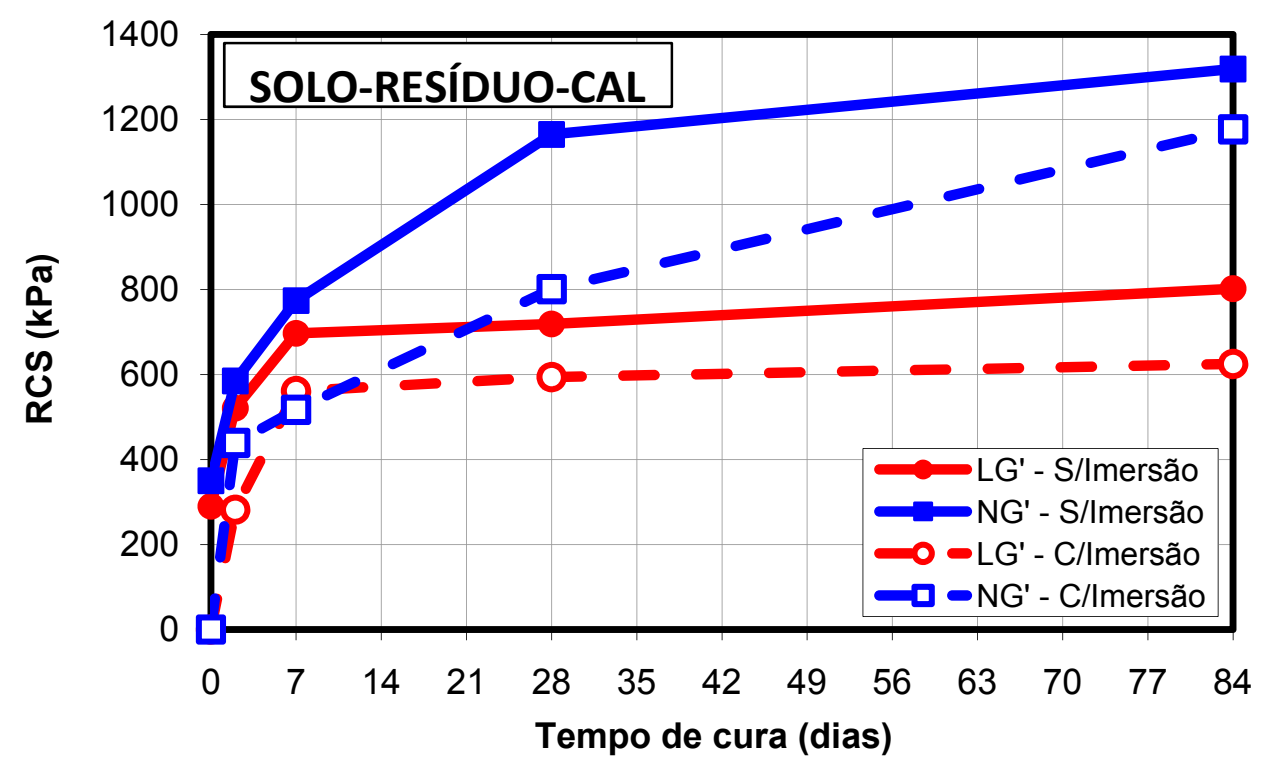

Figura 4.21 - Variação da RCS do solo LG' e NG' com a imersão em água e período de cura com adição do resíduo

Analisando-se os valores apresentados na Tabela 4.8 e ilustrados na Figura 4.20, observa-se para as misturas solo-cal que as resistências dos corpos-de-prova ensaiados com imersão do solo LG' repete o comportamento observado anteriormente para corpos-deprova ensaiados sem imersão, mantendo-se estabilizada a RCS após os 7 dias de cura, 
enquanto para o solo NG', a taxa de variação da resistência torna-se cada vez menor, mas ainda mostrando-se com um gradiente crescente aos 84 dias de cura, não indicando uma estabilização.

$\mathrm{Na}$ Figura 4.20, para corpos-de-prova ensaiados após imersão em água, ao se compararem as resistências das misturas constituídas pelos solos LG' e NG' ao longo do período de cura, observa-se que aos 2 dias, os valores são próximos entre si, favoráveis ao solo laterítico. Após os 7 dias de cura, ocorre uma inversão e a mistura com o solo NG' apresenta resistência 30\% superior à do solo LG'. Aos 84 dias, a diferença de resistência da mistura com o solo NG' é de $1.251 \mathrm{kPa}$, ou seja, a RCS é $115 \%$ superior a mistura com o solo laterítico, mostrando que há uma melhor ação cimentante da cal para solos argilosos não-lateríticos, desta forma, observa-se que a cal age na RCS de melhor forma ao longo do tempo de cura.

Ainda na Figura 4.20, para corpos-de-prova ensaiados após imersão em água, ao se compararem as perdas de resistências das misturas solo-cal constituídas pelos solos LG' e NG' ao longo do período de cura em relação às misturas ensaiadas sem imersão, observase que as misturas constituídas com o solo argiloso laterítico adquirem uma estabilização aos 7 dias de cura, observando-se para este solo perdas médias de resistência de $9 \%$. Para as misturas constituídas com o solo NG', observa-se que esta estabilização dá-se já aos 2 dia de cura, obtendo-se perdas médias de resistência de 18\%. Comparando-se as misturas compostas pelos dois solos, observa-se que apesar da rápida estabilização do solo NG', este se mostra mais susceptível a ação da água quando comparado às misturas solo-cal constituídas com o solo LG'.

Analisando-se os valores apresentados na Tabela 4.8 e ilustrados na Figura 4.21 observa-se para as misturas solo-resíduo-cal que as resistências dos corpos-de-prova do solo LG' ensaiados com imersão repetem o comportamento observado anteriormente para 
corpos-de-prova ensaiados sem imersão, mantendo-se estabilizada a RCS após os 7 dias de cura, enquanto para o solo NG', a taxa de variação da resistência torna-se cada vez menor, mas ainda mostrando-se com um gradiente crescente aos 84 dias de cura, não indicando uma estabilização.

Observa-se na Figura 4.21, para corpos-de-prova ensaiados após imersão em água, ao se compararem as resistências das misturas constituídas pelos solos LG' e NG' ao longo do período de cura, observa-se que aos 2 dias, os valores são próximos entre si, favoráveis ao solo não-laterítico. Após os 7 dias de cura, ocorre uma inversão e a mistura com o solo LG' apresenta resistência 9\% superior à do solo NG'. Aos 28 dias, as resistências do da mistura com o solo NG', novamente, apresenta-se superior à constituída pelo solo LG'. Aos 84 dias, a diferença de resistência da mistura com o solo NG' é de $552 \mathrm{kPa}$, ou seja, a RCS é $88 \%$ superior a mistura com o solo laterítico, mostrando que há uma melhor ação cimentante da cal para solos argilosos não-lateríticos que possuam uma granulometria mais grossa, desta forma, observa-se que a cal age na RCS de melhor forma ao longo do tempo de cura.

Ainda na Figura 4.21, para corpos-de-prova ensaiados após imersão em água, ao se compararem as perdas de resistências das misturas solo-resíduo-cal constituídas pelos solos LG' e NG' ao longo do período de cura em relação às misturas ensaiadas sem imersão, observa-se que as misturas constituídas com o solo argiloso laterítico adquirem uma estabilização aos 7 dias de cura, observando-se para este solo perdas médias de resistência de $20 \%$. Para as misturas constituídas com o solo NG', observa-se que esta estabilização dar-se já aos 2 dia de cura, obtendo-se perdas médias de resistência de $25 \%$. Comparando-se as misturas compostas pelos dois solos, observa-se que apesar da rápida estabilização da mistura com o solo NG', esta se mostra mais susceptível a ação da água quando comparado as misturas solo-resíduo-cal constituídas com o solo LG'. 
Ao se compararem as resistências após imersão de misturas solo-cal e solo-resíduocal, observa-se que as misturas solo-cal, considerando as resistências médias calculadas a partir dos tempos de cura estudados, apresentam resistências $85 \%$ e $121 \%$ superiores as misturas de solo-resíduo-cal, respectivamente para as misturas constituídas com o solo LG' e NG', concluindo-se que quanto à gênese, as misturas compostas com o solo NG', adquirem resistências mais elevadas ao longo do tempo de cura em relação às misturas constituídas com o solo LG'.

Finalmente, quando se comparam as perdas de resistência das misturas solo-cal em relação as misturas solo-resíduo-cal, observa-se que para as misturas constituídas com o solo LG' o aumento médio da perda de resistência, considerando as perdas após sua estabilização, ou seja, a partir dos 7 dias de cura, é de 127\% favorável as misturas solo-cal, concluindo que as misturas solo-resíduo-cal são mais susceptíveis à ação da água quando comparadas as misturas solo-cal. Para as misturas constituídas com o solo NG' o aumento médio da perda de resistência, considerando as perdas após sua estabilização, ou seja, a partir dos 2 dias de cura, é de $47 \%$ favorável às misturas solo-cal, concluindo-se que as misturas solo-resíduo-cal são mais susceptíveis a ação da água quando comparadas as misturas solo-cal.

\subsubsection{Ensaio de compressão simples - módulo tangente}

O estudo da deformabilidade das misturas de solo-cal e solo-resíduo-cal foi realizado através da análise da variação do módulo tangente inicial $\left(E_{0}\right)$ determinado a partir da curva 'tensão versus deformação' resultante do ensaio de compressão simples de cada uma das misturas. De maneira geral, o comportamento da deformabilidade e da resistência, apesar de diferirem numericamente, apresentam um padrão de variação bastante semelhante. Tal semelhança pressupõe que ambas sejam afetadas pelos mesmos mecanismos. 
As misturas constituídas pelos solos NG' e LG', sem resíduo e com $40 \%$ de resíduo, e estabilizadas com $0 \%, 5 \%$ e $10 \%$ de cal foram submetidas ao ensaio de compressão simples com cura de 7 dias para se obter o $E_{0}$. Para as misturas com o solo LA', foram realizados ensaios apenas com as misturas constituídas com $40 \%$ de resíduo e estabilizadas com $0 \%, 5 \%$ e $10 \%$ de cal. Os ensaios foram realizados observando-se os procedimentos descritos no Ítem 3.5.1 do Capítulo 3.

A Tabela 4.9 apresenta os valores do módulo tangente inicial $\left(E_{0}\right)$ aos 7 dias de cura para todas as misturas estudadas. O ganho relativo de rigidez das misturas com a adição de $5 \%$ e $10 \%$ de cal foi calculado com relação à resistência sem a adição de cal. As Figuras 4.22 e 4.23 ilustram, respectivamente, as variações do $E_{0}$ das misturas solo-cal e soloresíduo-cal, para o solo arenoso laterítico (LA') e os solos argilosos de comportamento laterítico (LG') e não-laterítico (NG').

Tabela 4.9 - Módulo tangente inicial para as misturas solo-cal, solo-resíduo e solo-resíduo-cal

\begin{tabular}{|c|c|c|c|c|c|}
\hline Tipo de solo & $\begin{array}{c}\text { Teor de } \\
\text { Resíduo } \\
(\%)\end{array}$ & $\begin{array}{l}\text { Teor de } \\
\text { Cal (\%) }\end{array}$ & $\begin{array}{c}\text { Módulo } \\
\text { Tangente } \\
\text { Inicial (MPa) }\end{array}$ & $\begin{array}{c}\text { Diferença } \\
\text { (MPa) }\end{array}$ & $\begin{array}{c}\text { Ganho } \\
(\%)\end{array}$ \\
\hline \multirow{6}{*}{ LG' } & \multirow{3}{*}{0} & 0 & 69 & & \\
\hline & & 5 & 481 & 412 & 597 \\
\hline & & 10 & 959 & 890 & 1290 \\
\hline & \multirow{3}{*}{40} & 0 & 26 & & \\
\hline & & 5 & 60 & 34 & 131 \\
\hline & & 10 & 389 & 363 & 1396 \\
\hline \multirow{6}{*}{ NG' } & \multirow{3}{*}{0} & 0 & 71 & & \\
\hline & & 5 & 309 & 238 & 335 \\
\hline & & 10 & 1343 & 1272 & 1792 \\
\hline & \multirow{3}{*}{40} & 0 & 12 & & \\
\hline & & 5 & 90 & 78 & 650 \\
\hline & & 10 & 246 & 234 & 1950 \\
\hline \multirow{3}{*}{ LA' $^{\prime}$} & \multirow{3}{*}{40} & 0 & 13 & & \\
\hline & & 5 & 40 & 27 & 208 \\
\hline & & 10 & 35 & 22 & 169 \\
\hline
\end{tabular}

Nota: Tempo de cura de 7 dias 


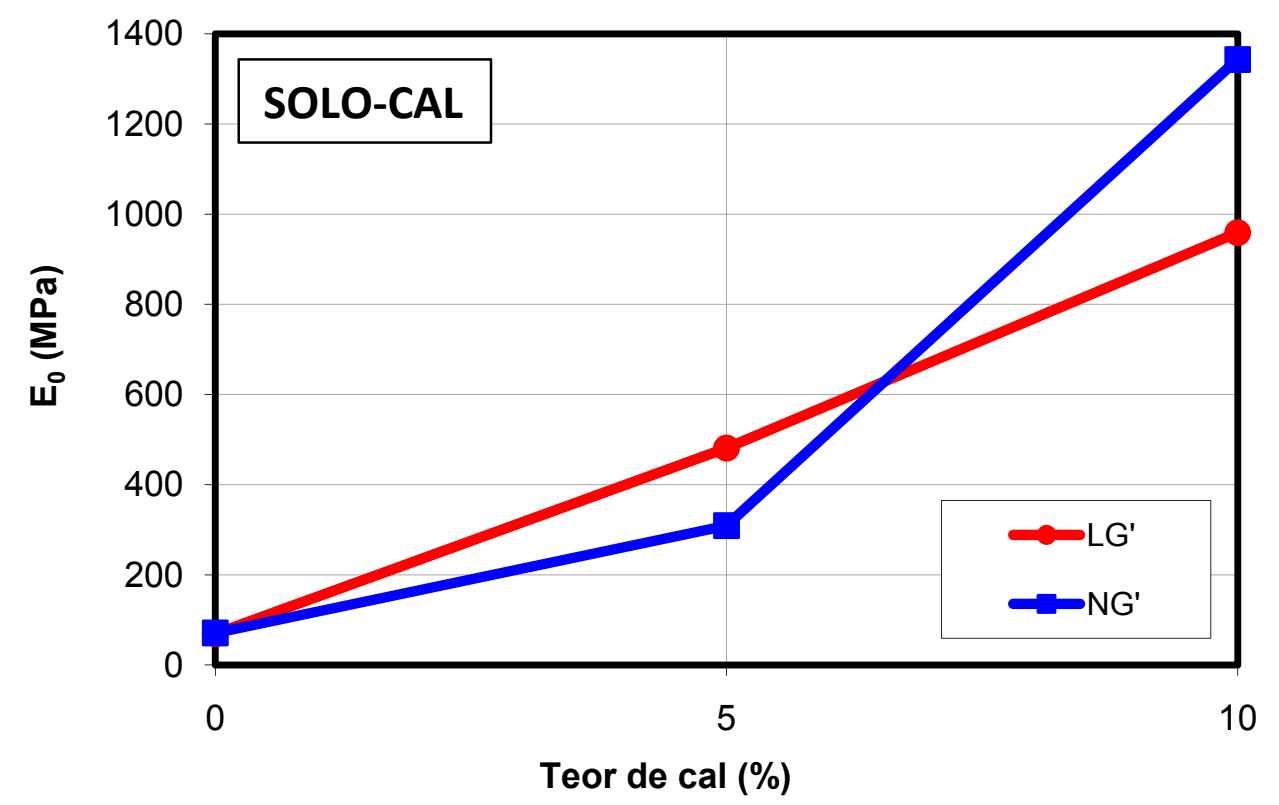

Figura 4.22 - Variação do $E_{0}$ aos 7 dias de cura para as misturas com os solos NG' e LG'

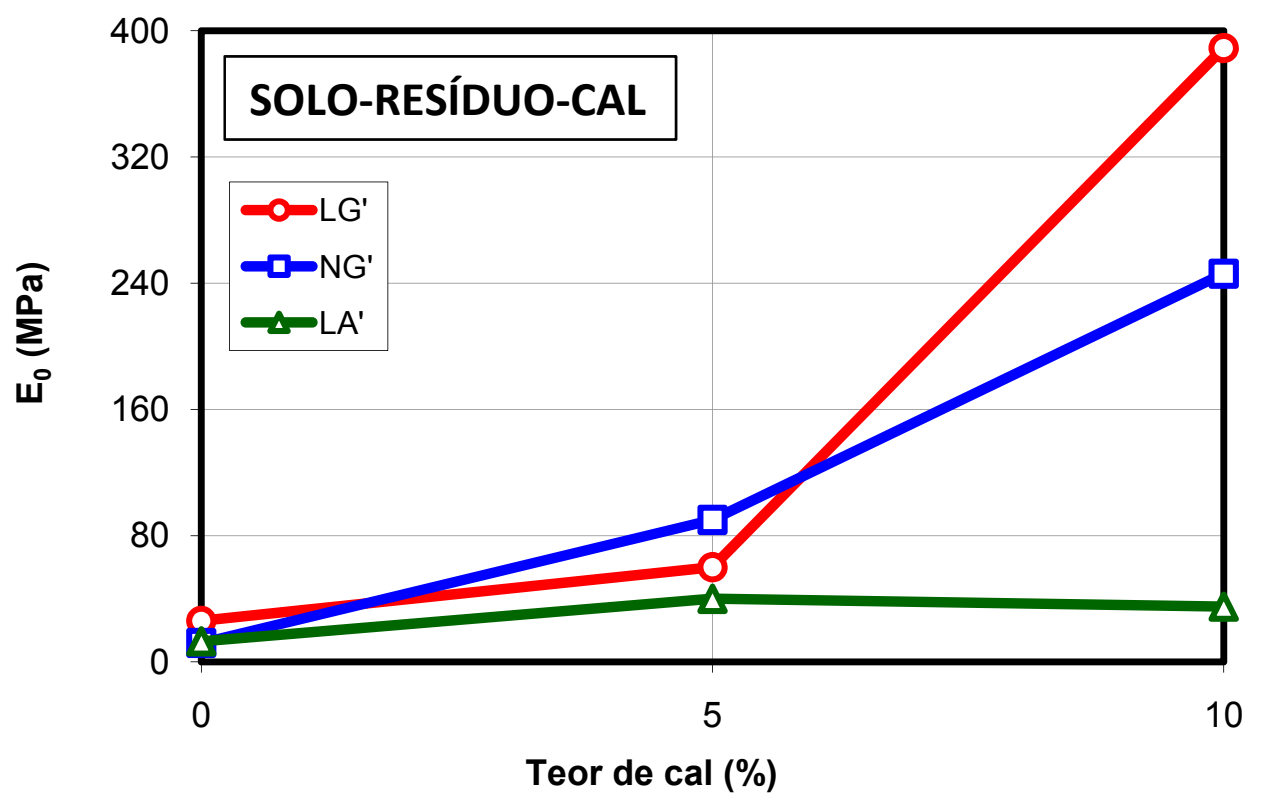

Figura 4.23 - Variação do $E_{0}$ aos 7 dias de cura para as misturas com o solo NG', LG', LA' e o resíduo

Analisando-se os valores apresentados na Tabela 4.9 e a ilustração da Figura 4.22, observa-se para os materiais sem a adição de cal que a rigidez para ambas as misturas argilosas são consideradas de mesma ordem de grandeza. Observa-se, ainda, que o acréscimo de cal conduz ao aumento do $E_{0}$ para ambos os solos. 
Ainda na Figura 4.22, observa-se para o teor de 5\%, que o solo LG' apresenta uma rigidez $36 \%$ superior à do solo NG'. Aproximadamente, após $6,5 \%$ de cal há uma inversão e o solo NG' passa a ter uma rigidez com a adição de cal superior a do solo LG'. Para o teor de $10 \%$ de cal, observa-se que a rigidez do solo NG' é $29 \%$ superior à do solo LG', caracterizando que para este teor a mistura de solo-cal composta pelo solo NG' apresenta melhor desempenho em relação à composta pelo solo LG', indicando também que para maiores teores do aditivo, a influência da gênese passa a ser predominante frente à influência da granulometria. Finalmente, destaca-se o crescimento pronunciado do $E_{0}$ do solo NG' quando se aumenta o teor de cal de $5 \%$ para $10 \%$ ao se comparar ao comportamento do solo LG' nas mesmas condições.

No tocante às misturas com $40 \%$ de resíduo constituídas pelos solos LA', NG' e LG', ao se analisar os valores apresentados na Tabela 4.9 e a ilustração da Figura 4.23, observase para os materiais sem a adição de cal, a rigidez da mistura constituída com o solo LG' é $54 \%$ superior as dos solos NG' e LA'. Observa-se, também, que o acréscimo de cal conduz ao aumento do $E_{0}$ para ambos os solos argilosos, fato que não ocorre para o solo LA'.

Ainda na Figura 4.23, para 5\% de cal, observa-se uma inversão e a rigidez do solo NG' é 33\% superior a mistura com solo LG'. Observa-se ainda, para este teor, que a mistura com o solo LA' apresenta um ganho de $208 \%$ em relação a mistura não estabilizada, e que o comportamento da mistura segue o previsto na biografia estudada, onde o efeito da cal é mais eficaz quando adicionado à solos argilosos. Para as misturas compostas com os solos argilosos, ao se elevar o teor de $5 \%$ para $10 \%$ de cal novamente há uma inversão e a rigidez do solo LG' passa a ser $37 \%$ superior à do solo NG', caracterizando que para este teor a mistura de solo-resíduo-cal composta pelo solo LG' apresenta melhor desempenho em relação à composta pelo solo NG'. Finalmente, destaca-se o crescimento pronunciado do $E_{0}$ do solo LG' quando se aumenta o teor de cal de $5 \%$ para $10 \%$ ao se comparar ao comportamento do solo NG' nas mesmas condições. Pôde-se observar também que houve 
uma redução de $13 \%$ do $E_{0}$ para o solo LA' no mesmo intervalo de variação do teor de cal, indicando que para misturas solo-resíduo-cal compostas com solo arenoso, a cal não tem um efeito positivo.

Finalmente, comparando-se os solos LG' e NG' sem resíduo em relação às misturas com a adição do resíduo, observa-se que a ação do resíduo agiu como um redutor do $\mathrm{E}_{0}$. Analisando os solos e as misturas não estabilizadas, observa-se que houve uma redução respectivamente de $62 \%$ e $83 \%$ para os solos LG' e NG'. Nas misturas de solo-cal, os $\mathrm{E}_{0}$ são superiores em relação às misturas de solo-resíduo-cal em média, considerando os dois teores de cal, $69 \%$ e $80 \%$ respectivamente para os solos LG' e NG'. Conclui-se que o acréscimo de cal nas misturas solo-cal constituídas com o solo NG' seja mais eficaz do que as constituídas com o solo LG', entretanto, há uma inversão quanto às misturas soloresíduo-cal na qual se apresenta mais eficientes quando compostas com o solo LG', indicando que o resíduo em conjunto com a ação cimentante da cal age de melhor forma com o material laterítico do que com o não-laterítico no tocante ao $\mathrm{E}_{0}$.

\subsubsection{Influência do tempo de cura no módulo tangente inicial}

O estudo da influência do tempo de cura nos permite avaliar o efeito das reações físico-químicas e as reações pozolânicas que ocorrem sobre as misturas devido à adição da cal. A análise foi realizada conforme já explicada anteriormente para a RCS.

Na Tabela 4.10 são apresentados os valores do $\mathrm{E}_{0}$ em função da adição do resíduo e variação do tempo de cura para misturas com o teor de $10 \%$ de cal. A diferença e o ganho relativo de rigidez com o aumento do tempo de cura foram calculados com relação à rigidez imediata e aos 2 dias de cura, respectivamente, para as misturas solo-cal e solo-resíduo-cal. As Figuras 4.24 e 4.25 ilustram, respectivamente, para as misturas solo-cal e solo-resíduocal, a variação do módulo tangente inicial das misturas em função do tempo de cura e da 
adição do resíduo. Observa-se que o aumento do tempo de cura conduz ao aumento do $\mathrm{E}_{0}$ para ambos os solos e misturas, e que este aumento tem um crescimento acentuado no período inicial de 7 dias.

Tabela 4.10 - Módulo tangente inicial das misturas de solo-resíduo-cal e solo-cal para os tempos de cura de $0,2,7,28$ e 84 dias

\begin{tabular}{|c|c|c|c|c|c|}
\hline Tipo de solo & $\begin{array}{c}\text { Teor de } \\
\text { Resíduo } \\
(\%)\end{array}$ & $\begin{array}{l}\text { Tempo de } \\
\text { Cura } \\
\text { (dias) }\end{array}$ & $\begin{array}{c}\text { Módulo } \\
\text { tangente } \\
\text { inicial (MPa) }\end{array}$ & $\begin{array}{c}\text { Diferença } \\
\text { (MPa) }\end{array}$ & $\begin{array}{c}\text { Ganho } \\
(\%)\end{array}$ \\
\hline \multirow{10}{*}{ LG' } & \multirow{5}{*}{0} & 0 & 97 & & \\
\hline & & 2 & 349 & 252 & 260 \\
\hline & & 7 & 959 & 862 & 889 \\
\hline & & 28 & 1014 & 917 & 945 \\
\hline & & 84 & 1157 & 1060 & 1093 \\
\hline & \multirow{5}{*}{40} & 0 & 0 & - & - \\
\hline & & 2 & 233 & & \\
\hline & & 7 & 389 & 156 & 67 \\
\hline & & 28 & 426 & 193 & 83 \\
\hline & & 84 & 478 & 245 & 105 \\
\hline \multirow{10}{*}{ NG' } & \multirow{5}{*}{0} & 0 & 56 & & \\
\hline & & 2 & 222 & 166 & 296 \\
\hline & & 7 & 1343 & 1287 & 2298 \\
\hline & & 28 & 1892 & 1836 & 3279 \\
\hline & & 84 & 1975 & 1919 & 3427 \\
\hline & \multirow{5}{*}{40} & 0 & 0 & - & - \\
\hline & & 2 & 105 & & \\
\hline & & 7 & 246 & 141 & 134 \\
\hline & & 28 & 725 & 620 & 590 \\
\hline & & 84 & 1057 & 952 & 907 \\
\hline
\end{tabular}

Nota: Teor de Cal $10 \%$ 


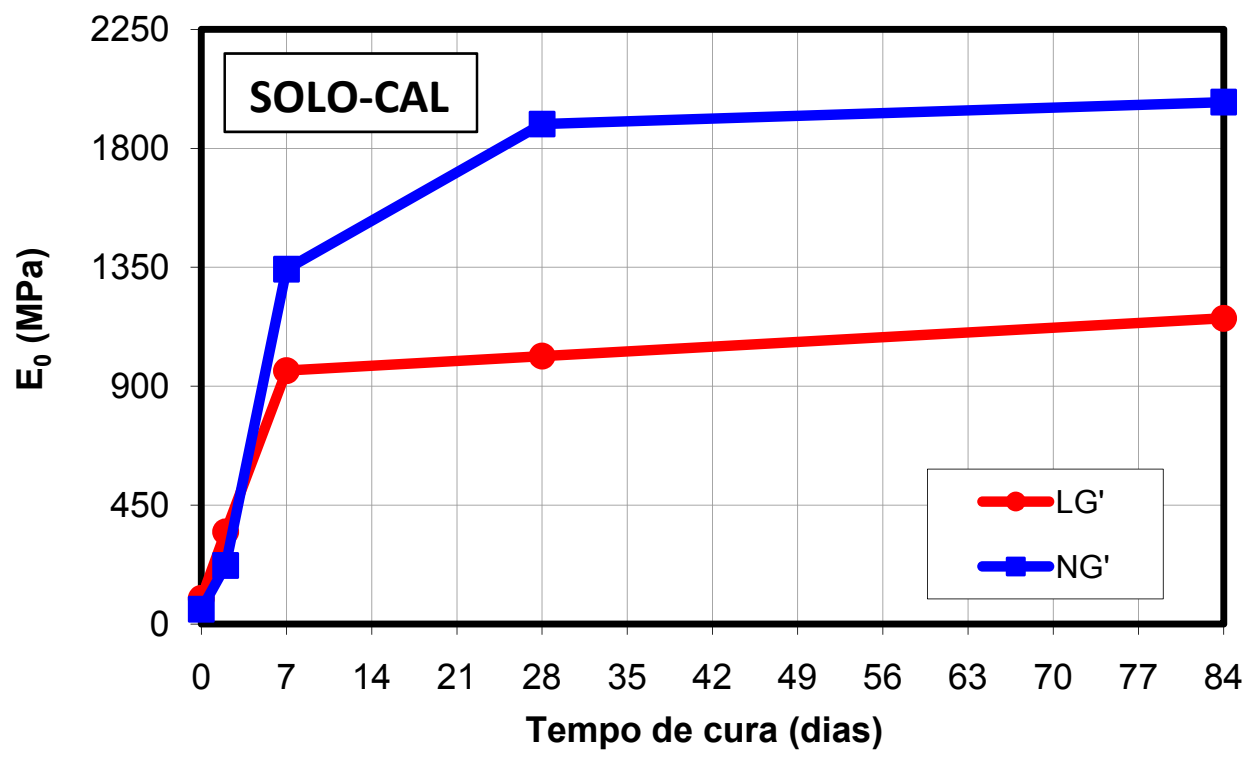

Figura 4.24 - Variação do $E_{0}$ do solo laterítico (LG') e não-laterítico (NG') com o tempo de cura para misturas com $10 \%$ de cal

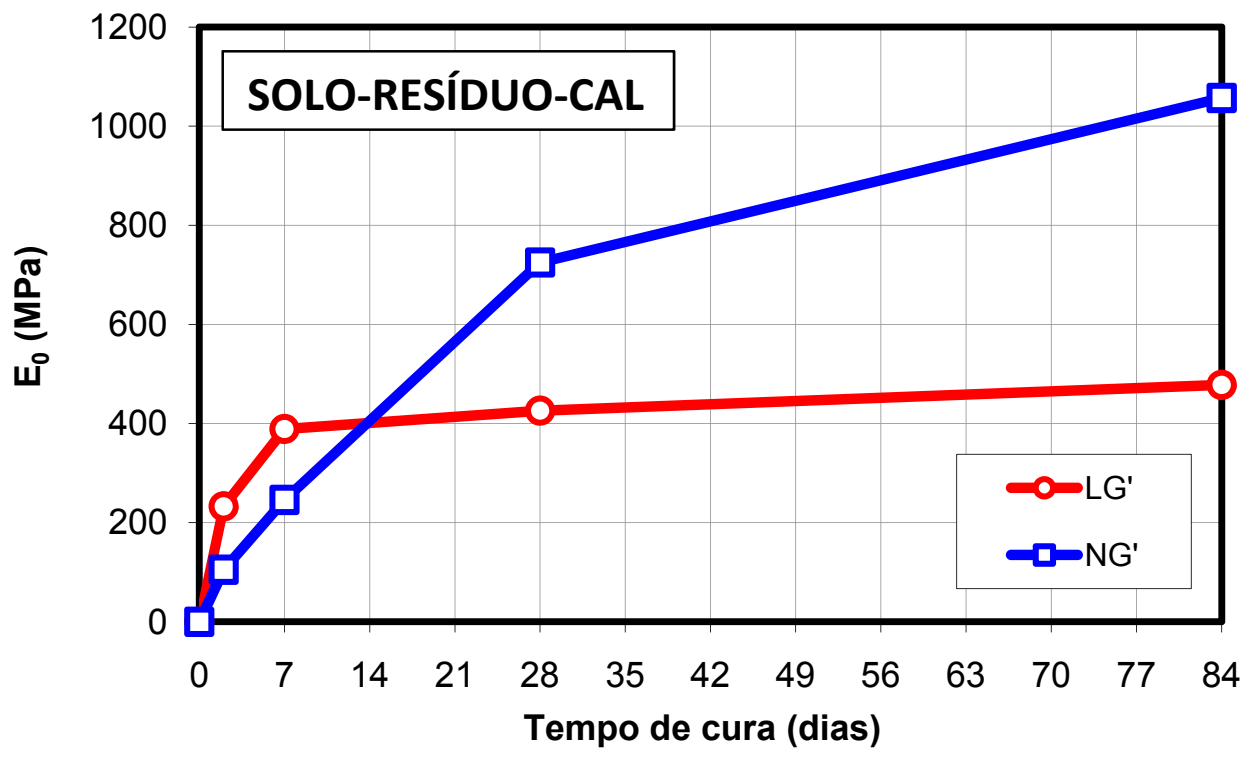

Figura 4.25 - Variação do $\mathrm{E}_{0}$ com o tempo de cura da mistura de resíduo com o solo laterítico (LG') e não-laterítico (NG') para misturas com $10 \%$ de cal

Analisando-se a Figura 4.24, no tocante à influência da gênese dos materiais sem a adição de resíduo, nota-se que o $\mathrm{E}_{0}$ mostra um crescimento acentuado até os 7 e 28 dias, respectivamente para as misturas constituídas com o solo LG' e NG', sendo que após estes períodos, observa-se uma tendência de estabilização. 
Ainda na Figura 4.24 e analisando na Tabela 4.10 os ganhos de rigidez, observa-se que para o solo NG', o ganho dá-se de maneira mais efetiva durante um período mais longo que o correspondente ao solo LG'. Ao se compararem as rigidezes das misturas constituídas pelos solos LG' e NG' ao longo do período de cura, observa-se que aos 2 dias, o solo LG' atinge uma rigidez $57 \%$ superior a do solo NG'. Aos 7 dias de cura, ocorre uma inversão e a mistura com o solo NG' apresenta rigidez 40\% superior à do solo LG'. Aos 84 dias, a diferença é de $818 \mathrm{MPa}$ favorável ao solo não-laterítico, indicando que este solo é mais reativo à cal no tocante à rigidez do que o solo laterítico.

Analisando-se a Figura 4.25 para misturas solo-resíduo-cal, no tocante à influência da gênese dos materiais, nota-se para a mistura constituída com o solo LG', que o $E_{0}$ mostra um crescimento acentuado até aos 7 dias, sendo que após este período, observa-se uma tendência de estabilização. Para o solo NG', observa-se que a mistura mostra maiores rigidezes com o aumento do tempo de cura, não indicando até aos 84 dias uma estabilização, supõe-se que o aumento continuado do $E_{0}$ ao longo do tempo de cura seja decorrente da adição do resíduo, caracterizando para elevados tempos de cura um melhor comportamento da ação da cal e adição do resíduo nas misturas com o solo NG'.

Ainda na Figura 4.25 e analisando na Tabela 4.10 os ganhos de rigidez, observa-se que para ambas as gêneses o ganho dá-se de maneira mais efetiva durante um período mais longo, destacando-se de forma mais eficiente para o solo NG'. Nota-se, portanto o mesmo comportamento que foi observado anteriormente para as misturas solo-cal.

Ao se compararem as rigidezes das misturas constituídas pelos solos LG' e NG' ao longo do período de cura, observa-se que aos 7 dias, o solo LG' atinge uma rigidez $58 \%$ superior a do solo NG'. Aos 14 dias, aproximadamente, as misturas apresentam rigidezes semelhantes e aos 28 dias de cura, ocorre uma inversão e a mistura com o solo NG' apresenta rigidez $70 \%$ superior à do solo LG'. Aos 84 dias, a diferença é de $579 \mathrm{MPa}$ 
favorável ao solo não-laterítico, indicando que a mistura é mais reativa à cal no tocante à rigidez do que a composta com solo laterítico.

Quando se analisam as rigidezes das misturas de solo-resíduo-cal em relação às misturas de solo-cal ao longo do período de cura, observa-se que a adição do resíduo provocou uma redução, aos 84 dias de cura, da rigidez de $59 \%$ e $46 \%$ respectivamente, para os solos LG' e NG'. Para a mistura solo-resíduo-cal com o solo NG' devido a taxa elevada de crescimento, supõe-se que poderá ao longo do tempo de cura adquirir patamares de rigidez próximas às misturas solo-cal. Conclui-se, portanto, que ao longo do tempo de cura, as misturas tanto solo-cal quanto solo-resíduo-cal compostas com o solo NG' obtiveram melhores resultados quando comparadas às compostas com o solo LG'.

\subsubsection{Influência da imersão em água no módulo tangente inicial}

Com o propósito de analisar a rigidez de camadas de base e sub-base de pavimentos submetidas à influência do aumento de umidade, realizaram-se os ensaios de compressão simples em corpos-de-prova previamente submetidos à imersão em água por um período de 24 horas, para todas as misturas curadas por 7 dias.

Na Tabela 4.11 são apresentados os valores do $E_{0}$ em função da adição do resíduo e variação do teor de cal e de resíduo, para corpos-de-prova ensaiados com imersão e sem imersão em água. Apresentam-se, também, as diferenças e perdas de rigidez decorrentes da imersão dos corpos-de-prova em água, para o tempo de 7 dias de cura. $\mathrm{O}$ cálculo da perda foi realizado conforme descrito anteriormente na análise da RCS. As Figuras 4.26 e 4.27 ilustram as variações do $\mathrm{E}_{0}$ com o teor de cal para as condições imersa e não imersa, respectivamente para as misturas solo-cal e solo-resíduo-cal. Observou-se que houve uma 
redução do $E_{0}$ quando os corpos-de-prova são ensaiados com imersão em relação aos ensaiados sem imersão e que os corpos-de-prova sem cal desintegraram-se.

Analisando-se os valores na Tabela 4.11 e as ilustrações das Figuras 4.26 e 4.27, observa-se que corpos-de-prova ensaiados após imersão apresentam rigidezes crescentes com o teor de cal, repetindo o comportamento observado anteriormente para corpos-deprova ensaiados sem imersão. Para as misturas estabilizadas com cal, observa-se para ambas as gêneses e misturas, exceto para o solo LG' ensaiado com imersão e teor de $5 \%$ de cal, que os corpos-de-prova ficaram estáveis, não se desintegrando, denotando o efeito positivo da ação da cal frente à imersão dos solos.

Tabela $4.11-\mathrm{E}_{0}$ e perdas de rigidez das misturas de solo-cal e solo-resíduo-cal para corposde-prova ensaiados com imersão em relação aos ensaiados sem imersão em água

\begin{tabular}{|c|c|c|c|c|c|c|}
\hline \multirow{2}{*}{ Tipo de solo } & \multirow{2}{*}{$\begin{array}{c}\text { Teor de } \\
\text { Resíduo } \\
(\%)\end{array}$} & \multirow{2}{*}{$\begin{array}{c}\text { Teor } \\
\text { de Cal } \\
(\%) \\
\end{array}$} & \multicolumn{2}{|c|}{$\mathrm{E}_{0}$ (MPa) } & \multirow{2}{*}{$\begin{array}{l}\text { Diferença } \\
\text { (MPa) }\end{array}$} & \multirow{2}{*}{$\begin{array}{c}\text { Perda } \\
(\%)\end{array}$} \\
\hline & & & Sem Imersão & Com Imersão & & \\
\hline \multirow{6}{*}{ LG' } & \multirow{3}{*}{0} & 0 & 69 & 0 & 69 & 100 \\
\hline & & 5 & 481 & 446 & 35 & 7 \\
\hline & & 10 & 959 & 677 & 282 & 29 \\
\hline & \multirow{3}{*}{40} & 0 & 26 & 0 & 26 & 100 \\
\hline & & 5 & 60 & 0 & 60 & 100 \\
\hline & & 10 & 389 & 352 & 37 & 10 \\
\hline \multirow{6}{*}{ NG' } & \multirow{3}{*}{0} & 0 & 71 & 0 & 71 & 100 \\
\hline & & 5 & 309 & 300 & 9 & 3 \\
\hline & & 10 & 1343 & 1251 & 92 & 7 \\
\hline & \multirow{3}{*}{40} & 0 & 12 & 0 & 12 & 100 \\
\hline & & 5 & 90 & 64 & 26 & 29 \\
\hline & & 10 & 246 & 205 & 41 & 17 \\
\hline
\end{tabular}

Nota: Tempo de Cura 7 dias 


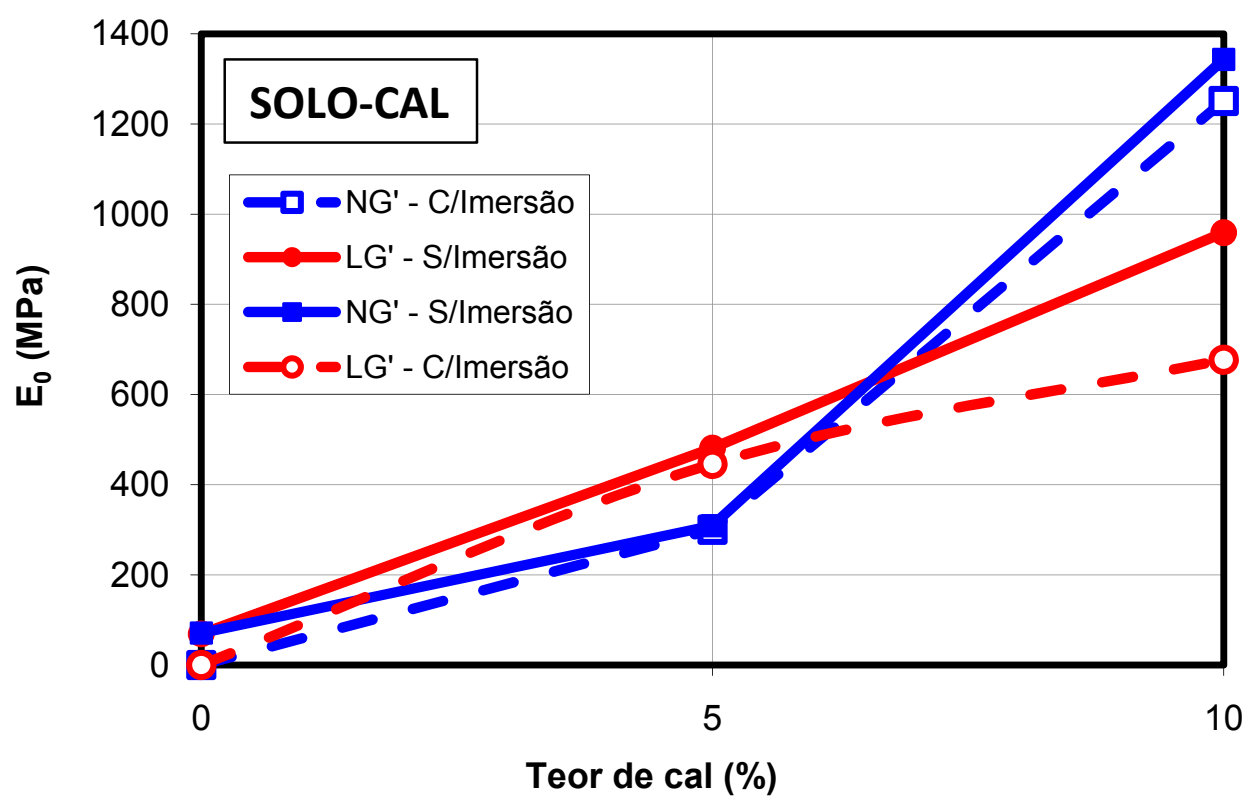

Figura 4.26 - Variação do $E_{0}$ do solo laterítico (LG') e não-laterítico (NG') com a imersão em água e teor de cal sem adição do resíduo

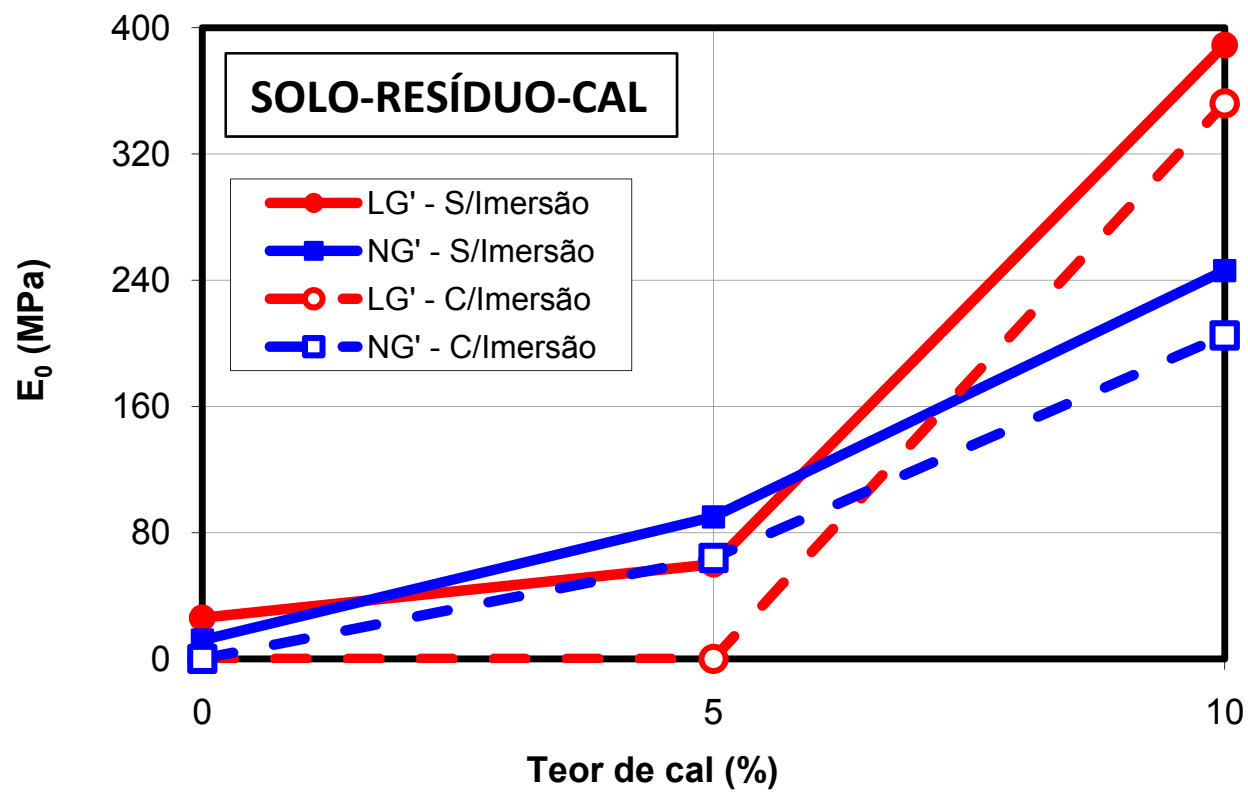

Figura 4.27 - Variação do $E_{0}$ do solo laterítico (LG') e não-laterítico (NG') com a imersão em água e teor de cal com adição do resíduo

Na Figura 4.26, observa-se para misturas imersas com o teor de $5 \%$, que o solo LG' apresenta uma rigidez $33 \%$ superior à do solo NG'. Aproximadamente, após $6 \%$ de cal há uma inversão e o solo NG' passa a ter uma rigidez com a adição de cal superior a do solo LG'. Para o teor de $10 \%$ de cal, observa-se que a rigidez do solo NG' é $46 \%$ superior à do 
solo LG', caracterizando que para este teor a mistura de solo-cal composta pelo solo NG' apresenta melhor desempenho em relação à composta pelo solo LG', indicando também que há uma redução do efeito negativo da influência da água. Finalmente, destaca-se o crescimento pronunciado do $\mathrm{E}_{0}$ do solo $\mathrm{NG}^{\prime}$ quando se aumenta o teor de cal de $5 \%$ para $10 \%$ ao se comparar ao comportamento do solo LG' nas mesmas condições.

Ainda na Figura 4.26, observa-se para misturas imersas com o teor de $5 \%$ de cal, a perda de rigidez devido à imersão é de 7\% e 3\% para os solos LG' e NG', respectivamente. Portanto, para este teor, a influência da água é reduzida o suficiente para poder inclusive serem consideradas de mesma ordem de grandeza da dispersão dos resultados do ensaio. Para o teor de $10 \%$ de cal, a queda de rigidez devido à imersão é, respectivamente, de $29 \%$ e 7\% para os solos LG' e NG'. Para o solo NG' pode-se considerar que a ação da cal foi mais efetiva em relação ao solo LG' e que o efeito da adição de cal nos corpos-de-prova ensaiados com imersão em água não alterou de maneira expressiva o valor de $\mathrm{E}_{0}$. No tocante ao solo LG', observa-se que houve um aumento da queda de rigidez de $7 \%$ para $29 \%$, quando o teor de cal cresce de $5 \%$ para $10 \%$, contrariando a expectativa quanto ao efeito positivo da cal neste solo para o teor de $10 \%$.

No tocante à influência da variação de umidade no $E_{0}$ das misturas com a adição de resíduo, a Figura 4.27 permite observar, para misturas imersas com o teor de $5 \%$ de cal, que a perda de rigidez devido à imersão é de $100 \%$ e $29 \%$ para os solos LG' e NG', respectivamente. Portanto, para este teor, a mistura com o solo NG' é menos suceptível à ação da água. Para o teor de $10 \%$ de cal, a perda de rigidez devido à imersão é de $10 \%$ e $17 \%$ respectivamente para os solos LG' e NG', indicando que o aumento da quantidade de estabilizante contribui para a redução da suscetibilidade das misturas de solo e resíduo à ação da água, destacando-se para teores mais elevados que a ação da cal é mais efetiva na mistura solo-resíduo-cal composta pelo solo LG'. 
Comparando-se o efeito da imersão em água nas misturas solo-cal e solo-resíduocal, ensaiadas após 7 dias de cura, observa-se que no $E_{0}$, para ambos os solos, as misturas de solo-resíduo-cal são mais susceptíveis à ação da água. A perda de rigidez, para ensaios com imersão, das misturas solo-resíduo-cal em relação às misturas solo-cal, considerando as rigidezes médias calculadas a partir dos dois teores, é de $37 \%$ e $83 \%$ respectivamente, para as misturas compostas com os solos LG' e NG'. Estes percentuais mostram que as misturas imersas de solo-resíduo-cal compostas com o solo NG' apresentam-se mais susceptíveis à adição do resíduo, apresentando maiores perdas de rigidez quando comparadas às misturas imersas de solo-cal.

Finalmente, a variação do $E_{0}$ das misturas ensaiadas com imersão comporta-se conforme já explicado anteriormente para as misturas sem imersão, na qual misturas solocal constituídas com o solo NG' apresentam melhor desempenho do que a do solo LG', entretanto, havendo uma inversão quanto às misturas solo-resíduo-cal, as quais se apresentam mais eficientes quando compostas com o solo LG'.

\subsubsection{Influência do tempo de cura para misturas ensaiadas após imersão em água no módulo tangente inicial}

Na Tabela 4.12 são apresentados os valores do $\mathrm{E}_{0}$ em função da adição do resíduo e variação do tempo de cura para misturas com o teor de $10 \%$ de cal, para corpos-de-prova ensaiados com imersão e sem imersão em água. Apresentam-se, também, a diferença e a perda relativa de rigidez das misturas imersas em relação às não imersas, calculada com relação à rigidez aos 2 dias de cura, pois todas as misturas ensaiadas sem cura, desintegraram-se após imersão. 
As Figuras 4.28 e 4.29 ilustram, respectivamente, a variação do módulo tangente inicial das misturas solo-cal e solo-resíduo-cal em função do tempo de cura para corpos-deprova ensaiados sem imersão e com imersão prévia em água. Observa-se que, no geral, corpos-de-prova ensaiados após imersão em água apresentam um padrão de variação de rigidez ao longo do tempo de cura semelhante ao observado anteriormente para as misturas solo-cal e solo-resíduo-cal ensaiadas sem imersão, ou seja, o aumento do tempo de cura conduz ao aumento do $E_{0}$ para ambos os solos e misturas, e que a rigidez cresce de maneira mais acentuada no período inicial de 7 dias, destacando-se um maior incremento para as misturas constituídas com o solo NG'.

Tabela 4.12 - Módulo tangente inicial das misturas e a perda do $E_{0}$ para corpos-de-prova ensaiados com imersão e sem imersão em água em função do tempo de cura

\begin{tabular}{|c|c|c|c|c|c|c|}
\hline \multirow{2}{*}{$\begin{array}{l}\text { Tipo de } \\
\text { solo }\end{array}$} & \multirow{2}{*}{$\begin{array}{c}\text { Teor de } \\
\text { Resíduo } \\
(\%)\end{array}$} & \multirow{2}{*}{$\begin{array}{c}\text { Tempo de } \\
\text { Cura } \\
\text { (Dias) }\end{array}$} & \multicolumn{2}{|c|}{$\mathrm{E}_{0}(\mathrm{MPa})$} & \multirow{2}{*}{$\begin{array}{c}\text { Diferença } \\
\text { (MPa) }\end{array}$} & \multirow{2}{*}{$\begin{array}{c}\text { Perda } \\
(\%)\end{array}$} \\
\hline & & & Sem Imersão & Com Imersão & & \\
\hline \multirow{10}{*}{ LG' } & \multirow{5}{*}{0} & 0 & 97 & 0 & 97 & 100 \\
\hline & & 2 & 349 & 207 & 142 & 41 \\
\hline & & 7 & 959 & 677 & 282 & 29 \\
\hline & & 28 & 1014 & 737 & 277 & 27 \\
\hline & & 84 & 1157 & 881 & 276 & 24 \\
\hline & \multirow{5}{*}{40} & 0 & 0 & 0 & 0 & - \\
\hline & & 2 & 233 & 209 & 24 & 10 \\
\hline & & 7 & 389 & 352 & 37 & 10 \\
\hline & & 28 & 426 & 386 & 40 & 9 \\
\hline & & 84 & 478 & 428 & 50 & 10 \\
\hline \multirow{10}{*}{ NG' } & \multirow{5}{*}{0} & 0 & 56 & 0 & 56 & 100 \\
\hline & & 2 & 222 & 133 & 89 & 40 \\
\hline & & 7 & 1343 & 1251 & 92 & 7 \\
\hline & & 28 & 1892 & 1356 & 536 & 28 \\
\hline & & 84 & 1975 & 1409 & 566 & 29 \\
\hline & \multirow{5}{*}{40} & 0 & 0 & 0 & 0 & - \\
\hline & & 2 & 105 & 92 & 13 & 12 \\
\hline & & 7 & 246 & 205 & 41 & 17 \\
\hline & & 28 & 725 & 645 & 80 & 11 \\
\hline & & 84 & 1057 & 864 & 193 & 18 \\
\hline
\end{tabular}




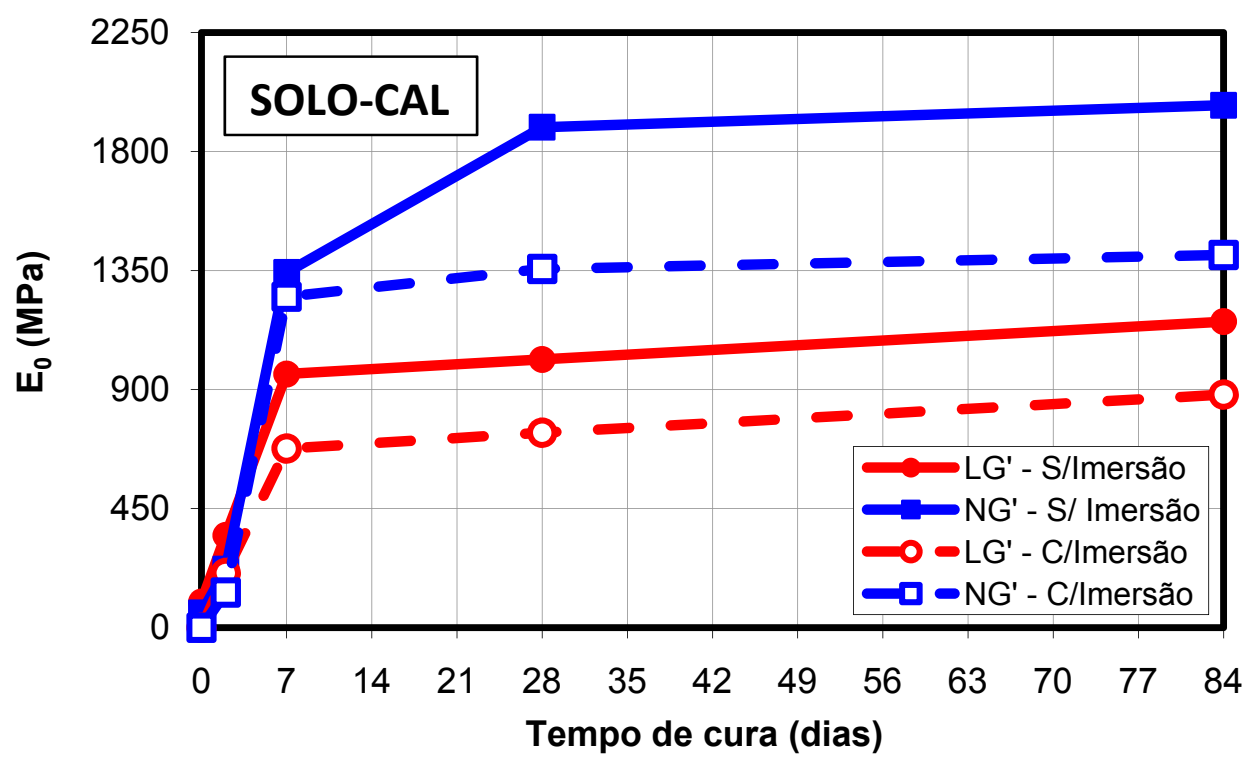

Figura 4.28 - Variação do $E_{0}$ do solo LG' e NG' com a imersão em água e período de cura sem adição do resíduo

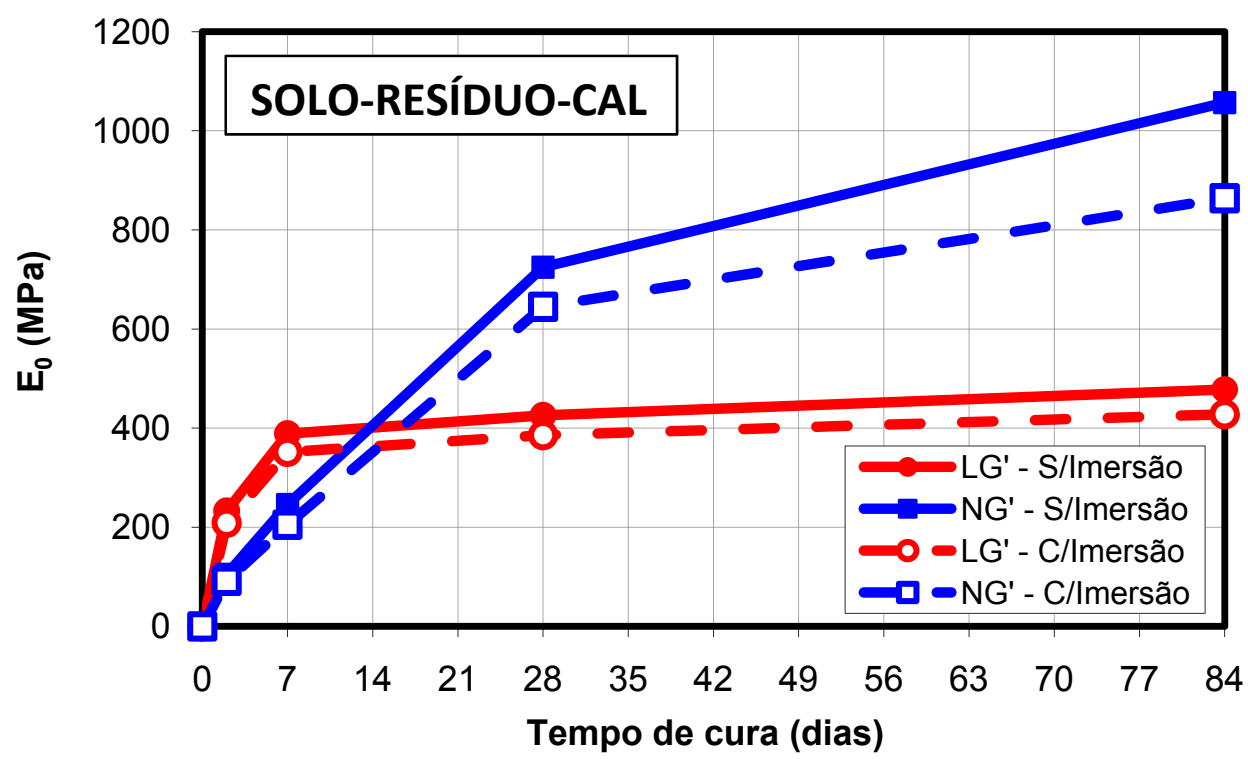

Figura 4.29 - Variação do $E_{0}$ do solo LG' e NG' com a imersão em água e período de cura com adição do resíduo

Analisando-se a rigidez das misturas solo-cal, observa-se, conforme a Tabela $4.12 \mathrm{e}$ a Figura 4.28, que os corpos-de-prova ensaiados após imersão apresentam um comportamento semelhante ao dos ensaiados sem imersão. Nota-se que o $E_{0}$, das misturas ensaiadas com imersão, mostra um crescimento acentuado até aos 7 e 28 dias, 
respectivamente para as misturas constituídas com o solo LG' e NG', sendo que após estes períodos, observa-se uma tendência de estabilização.

$\mathrm{Na}$ Figura 4.28, para corpos-de-prova ensaiados após imersão em água, ao se compararem as rigidezes das misturas constituídas pelos solos LG' e NG' ao longo do período de cura, observa-se que aos 2 dias, os valores são próximos entre si, mas favoráveis ao solo laterítico. Após os 7 dias de cura, ocorre uma inversão e a mistura com o solo NG' apresenta rigidez $46 \%$ superior à do solo LG'. Aos 84 dias, a diferença de rigidez da mistura com o solo LG' e do solo NG' é de $528 \mathrm{MPa}$, favorável a este último, o que corresponde a um percentual de $37 \%$, mostrando que a ação cimentante da cal é mais efetiva para solos argilosos não-lateríticos.

Ainda na Figura 4.28 e analisando as perdas de rigidez na Tabela 4.12, observa-se para o solo LG' um decréscimo da perda de rigidez ao longo do tempo de cura, sendo esta perda $24 \%$ aos 84 dias. Para o solo NG', de maneira geral, observa-se também um decréscimo da perda de rigidez ao longo do tempo de cura, com exceção da perda aos 7 dias de cura, apresentando aos 84 dias uma perda de 29\%. Observa-se, que quando se analisa a diferença de rigidez devido à imersão em água aos 84 dias de cura, proporcionalmente, o efeito negativo da imersão está na relação $1: 2$, respectivamente para os solos LG' e NG', entretanto, em percentuais, as perdas podem ser consideradas da mesma ordem de grandeza para ambos os solos.

$\mathrm{Na}$ Tabela 4.12 e conforme a ilustração da Figura 4.29, observa-se que os corposde-prova ensaiados após imersão apresentam um comportamento semelhante aos ensaiados sem imersão. Para misturas constituídas com o solo LG' e ensaiadas com imersão, nota-se que o $\mathrm{E}_{0}$ das misturas solo-resíduo-cal mostra um crescimento acentuado até aos 7 dias, sendo que após este período, observa-se uma tendência de estabilização. Para o solo NG', observa-se que a mistura mostra maiores rigidezes com o aumento do 
tempo de cura, não indicando até aos 84 dias uma estabilização, supõe-se que o aumento continuado do $\mathrm{E}_{0}$ ao longo do tempo de cura seja decorrente da adição do resíduo, caracterizando para elevados tempos de cura um melhor comportamento da ação da cal e adição do resíduo nas misturas com o solo NG'.

Ao se compararem as rigidezes das misturas constituídas pelos solos LG' e NG' ao longo do período de cura, observa-se que aos 7 dias, o solo LG' atinge uma rigidez $42 \%$ superior a do solo NG'. Após 14 dias, aproximadamente, observa-se uma inversão e a mistura com o solo NG' apresenta com o aumento do teor de cal uma rigidez superior à do solo LG' e aos 28 dias de cura, o solo NG' apresenta rigidez $40 \%$ superior à do solo LG'. Aos 84 dias, a diferença é de $436 \mathrm{MPa}$ favorável ao solo não-laterítico, mostrando que há uma melhor ação cimentante da cal para solos argilosos não-lateríticos

Ainda na Figura 4.29 e analisando as perdas de rigidez com a imersão em água na Tabela 4.12, observa-se para o solo LG' uma estabilização da perda de rigidez ao longo do tempo de cura, sendo esta perda $10 \%$ aos 84 dias, equivalente a 50 MPa. Para o solo NG', não se observa uma seqüência bem definida da perda de rigidez ao longo do tempo de cura. Para este solo, aos 84 dias, a perda é de 18\%, correspondente a $193 \mathrm{MPa}$. Observa-se, que quando se analisa a diferença de rigidez devido à imersão em água, aos 84 dias de cura, proporcionalmente, o efeito negativo da imersão está numa relação aproximada de 1:4, respectivamente para os solos LG' e NG', entretanto, os percentuais de perdas estão numa relação aproximada de 1:2, respectivamente para os solos LG' e NG'. Conclui-se, portanto que o solo LG' é menos susceptível à ação negativa da água, apesar das misturas compostas com o solo NG' apresentarem rigidezes ao longo do tempo de cura superiores à das misturas com o solo LG'.

Ao se compararem as rigidezes após imersão de misturas solo-cal em relação às misturas de solo-resíduo-cal ao longo do período de cura, observa-se que a adição do 
resíduo provocou uma redução da rigidez de $51 \%$ e $39 \%$, aos 84 dias de cura, respectivamente, para os solos LG' e NG'. Conclui-se que as misturas imersas com o solo LG' foram mais susceptíveis à adição do resíduo quando comparadas às misturas com o solo NG'. Destaca-se ainda, para as mistura solo-resíduo-cal compostas com o solo NG', que devido à sua elevada taxa de crescimento do $E_{0}$ ao longo do tempo de cura, que para períodos de cura mais longos, é provável que a rigidez destas misturas aproxime-se da rigidez das misturas solo cal.

Analisando-se as perdas relativas de rigidez com imersão na Tabela 4.12, observase para ambos os solos uma redução da perda de rigidez ao longo do tempo de cura quando adicionado o resíduo. As misturas solo-cal compostas com o solo LG' apresentam perdas de $24 \%$, quando se adiciona o resíduo, a perda reduz-se para $10 \%$. Para o solo NG', a perda é de $29 \%$ para misturas solo-cal, havendo uma redução para $18 \%$ quando há a adição do resíduo. Conclui-se, portanto, que as misturas solo-resíduo-cal são menos susceptíveis à ação da água, quando comparadas às misturas solo-cal. Supõe-se, portanto que a adição do resíduo contribui com a ação cimentante da cal reduzindo à influência da ação da água.

\subsubsection{Ensaio de compressão diametral}

Os ensaios de compressão diametral foram realizados a fim de se avaliar a resistência à tração que camadas estabilizadas com cal podem oferecer, tanto para misturas solo-cal como para misturas solo-resíduo-cal. O State of the Art 5 - Lime Stabilization (TRB, 1987) afirma que apesar da RCS ser o parâmetro mais utilizado para se avaliar o comportamento de misturas estabilizadas com cal, a resistência à tração tem maior importância no desempenho destas misturas. Neste estudo, observou-se que, de maneira geral, as resistências à tração apresentaram um padrão de variação bastante semelhante ao 
apresentado no ensaio de RCS, tanto para misturas solo-cal como para as misturas de soloresíduo-cal. Tal semelhança pressupõe que ambas sejam afetadas pelos mesmos mecanismos.

Os ensaios foram realizados observando-se os procedimentos descritos no Ítem 3.5.1 do Capítulo 3 e conforme descritos anteriormente para o ensaio de compressão simples. A Tabela 4.13 apresenta os valores de resistências à compressão diametral (RCD) aos 7 dias de cura para todas as misturas estudadas. $O$ ganho relativo de resistência das misturas com a adição de $5 \%$ e $10 \%$ de cal foi calculado com relação à resistência sem a adição de cal.

As Figuras 4.30 e 4.31 ilustram, respectivamente, as variações da RCD das misturas solo-cal e solo-resíduo-cal, para o solo arenoso laterítico (LA') e os solos argilosos de comportamento laterítico (LG') e não-laterítico (NG').

Tabela 4.13 - Resistência à compressão diametral para as misturas solo-cal, solo-resíduo e solo-resíduo-cal

\begin{tabular}{|c|c|c|c|c|c|}
\hline Tipo de solo & $\begin{array}{c}\text { Teor de } \\
\text { Resíduo } \\
\text { (\%) }\end{array}$ & $\begin{array}{l}\text { Teor de } \\
\text { cal (\%) }\end{array}$ & $\begin{array}{c}\text { Resistência à } \\
\text { compressão } \\
\text { diametral (kPa) }\end{array}$ & $\begin{array}{l}\text { Diferença } \\
\qquad(\mathrm{kPa})\end{array}$ & $\begin{array}{c}\text { Ganho } \\
(\%)\end{array}$ \\
\hline \multirow{6}{*}{ LG' } & \multirow{3}{*}{0} & 0 & 23 & & \\
\hline & & 5 & 92 & 69 & 298 \\
\hline & & 10 & 144 & 121 & 522 \\
\hline & \multirow{3}{*}{40} & 0 & 26 & & \\
\hline & & 5 & 34 & 8 & 32 \\
\hline & & 10 & 115 & 89 & 345 \\
\hline \multirow{6}{*}{ NG' } & \multirow{3}{*}{0} & 0 & 34 & & \\
\hline & & 5 & 80 & 46 & 133 \\
\hline & & 10 & 180 & 145 & 425 \\
\hline & \multirow{3}{*}{40} & 0 & 11 & & \\
\hline & & 5 & 62 & 51 & 447 \\
\hline & & 10 & 119 & 108 & 945 \\
\hline \multirow{3}{*}{$\mathrm{LA}^{\prime}$} & \multirow{3}{*}{40} & 0 & 11 & & \\
\hline & & 5 & 23 & 11 & 100 \\
\hline & & 10 & 29 & 17 & 151 \\
\hline
\end{tabular}

Nota: Tempo de cura de 7 dias 


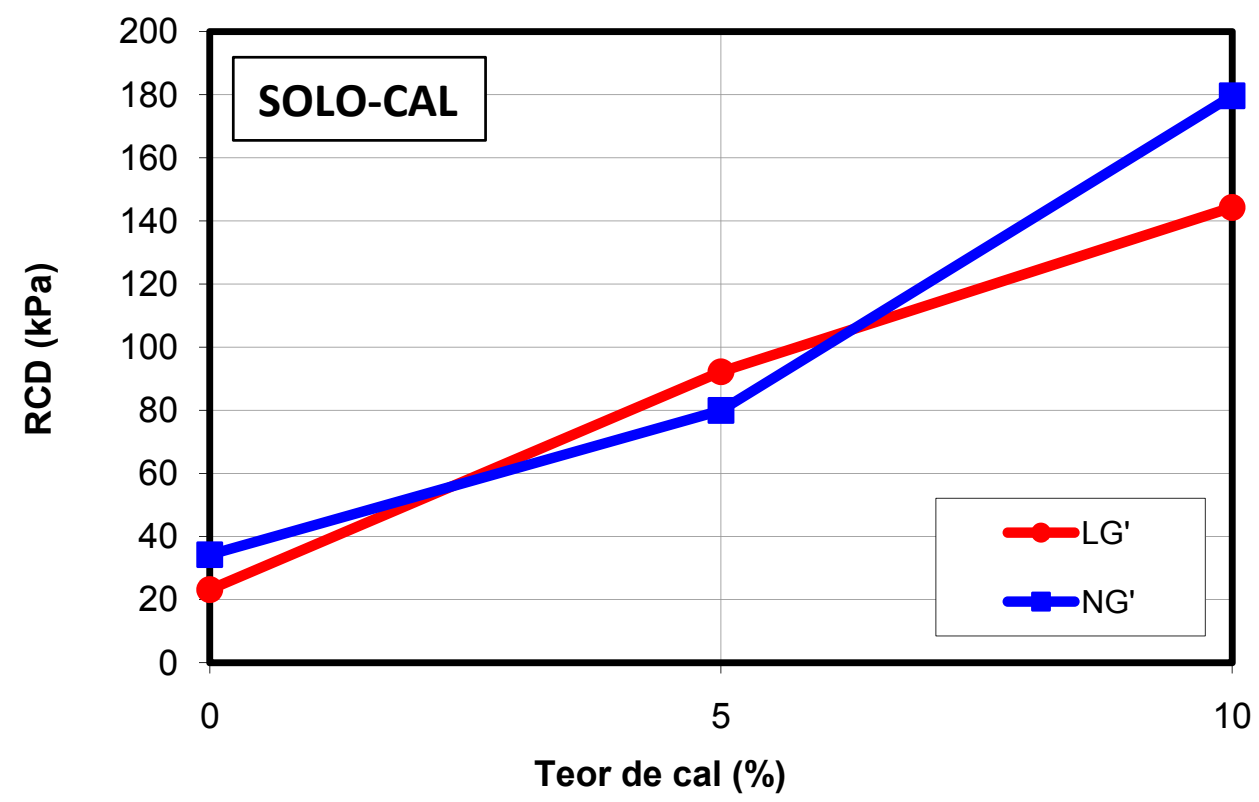

Figura 4.30 - Resistência à compressão diametral aos 7 dias de cura para as misturas com o solo NG' e LG'

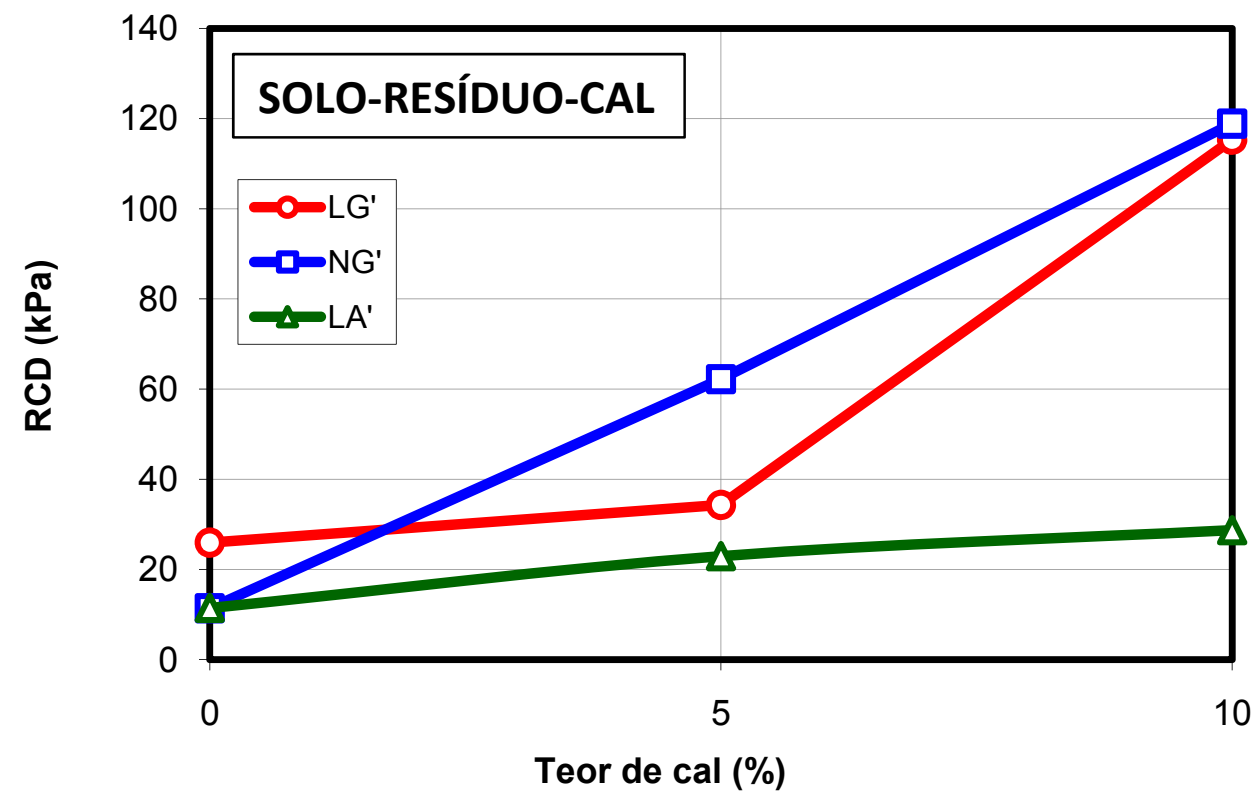

Figura 4.31 - Resistência à compressão diametral aos 7 dias de cura das misturas com o solo NG', LG', LA' e o resíduo

Analisando-se os valores apresentados na Tabela 4.13 e a ilustração da Figura 4.30, observa-se que o acréscimo de cal conduz ao aumento da RCD para ambos os solos. Considerando-se a média calculada para os dois solos e calculando-se o acréscimo de 
resistência devido à cal com relação à resistência do solo natural, conclui-se que existe um ganho de resistência de $216 \%$ e $474 \%$, respectivamente para $5 \%$ e $10 \%$ de cal.

Ainda na Figura 4.30, conforme já explicado anteriormente para o ensaio de RCS, observa-se que para o teor de $5 \%$, supõe-se que o efeito da granulometria seja maior que a da gênese, tendo em vista que o solo LG', "mais fino", apresenta uma resistência 13\% superior à do solo NG'. Para o teor de $10 \%$ de cal, observa-se uma inversão, ou seja, a resistência do solo NG' é $20 \%$ superior à do solo LG', indicando que para maiores teores do aditivo, a influência da gênese passa a ser predominante frente à influência da granulometria. Finalmente, destaca-se o crescimento pronunciado da RCD do solo NG' quando se aumenta o teor de cal de $5 \%$ para $10 \%$ ao se comparar ao comportamento do solo LG' nas mesmas condições.

No tocante às misturas com $40 \%$ de resíduo constituídas pelos solos LA', NG' e LG', ao se analisar os valores apresentados na Tabela 4.13 e a ilustração da Figura 4.31, observa-se que, o acréscimo de cal conduz ao aumento da RCD para ambos os solos argilosos e para o solo arenoso. Para os materiais sem a adição de cal, a resistência do solo LG' é $32 \%$ superior ao do solo NG' e LA'. Para $5 \%$ de cal, ao comparar as misturas compostas pelo solo argiloso laterítico e o argiloso não-laterítico, observa-se uma resistência de $18 \%$ favorável à mistura com solo NG'. Neste mesmo teor de cal, a mistura constituída com o solo LA' apresentou uma resistência $52 \%$ superior à resistência da mistura solo-resíduo e manteve uma resistência $58 \%$ inferior quando comparado com a média dos dois solos argilosos. Para as misturas compostas com os solos argilosos, ao se elevar o teor de $5 \%$ para $10 \%$ de cal, observa-se, ao comparar as misturas compostas pelo solo LG' e o NG', uma resistência 3\% favorável à mistura com o solo NG', este valor pode ser inclusive considerado da mesma ordem de grandeza da dispersão dos resultados do ensaio. Pôde-se observar também que houve um acréscimo de $21 \%$ da RCD para o solo LA' no mesmo intervalo de variação do teor de cal, este fato não ocorreu na RCS, evidenciando 
que a ação da cal atua de maneira mais eficaz na resistência à tração do que à compressão, justificando o que já era esperado para solos arenosos.

Finalmente, comparando-se os solos NG' e LG' sem resíduo em relação às misturas com a adição do resíduo, observa-se que a ação do resíduo agiu como um redutor da RCD. Entretanto, todas as misturas de solo-resíduo estabilizadas com cal, adquiriram resistências superiores quando comparadas às mesmas não estabilizadas. Para as misturas de solo-cal, as RCD são superiores em relação às misturas de solo-resíduo-cal em média $87 \%$ e $63 \%$ respectivamente para os solos NG' e LG'.

\subsubsection{Influência do tempo de cura na compressão diametral}

O estudo para os solos NG' e LG', foi feito para a porcentagem de $10 \%$ de cal, que corresponde ao teor que proporcionou os maiores valores de RCD, e para os teores de 0 e $40 \%$ de resíduo. Os tempos de cura considerados foram de $0,2,7,28$ e 84 dias em câmara úmida.

$\mathrm{Na}$ Tabela 4.14 são apresentados os valores da RCD em função da adição do resíduo e variação do tempo de cura. A diferença e o ganho relativo de resistência das misturas solo-cal e solo-resíduo-cal com o aumento do tempo de cura foram calculados com relação à resistência com 2 dias de cura. As Figuras 4.32 e 4.33 ilustram, respectivamente, para as misturas solo-cal e solo-resíduo-cal, a variação da resistência à compressão diametral das misturas em função do tempo de cura e da adição do resíduo para corpos-deprova ensaiados sem imersão prévia em água. Observa-se que o aumento do tempo de cura conduz ao aumento da RCD para ambos os solos e misturas, e que este aumento tem um crescimento acentuado no período inicial de 7 dias, destacando-se de forma mais favorável para o solo NG'. 
Tabela 4.14 - Resistência à compressão diametral das misturas de solo-resíduo-cal e solo-cal para os tempos de cura de $0,2,7,28$ e 84 dias

\begin{tabular}{|c|c|c|c|c|c|}
\hline Tipo de solo & $\begin{array}{c}\text { Teor de } \\
\text { Resíduo } \\
\text { (\%) }\end{array}$ & $\begin{array}{c}\text { Tempo de } \\
\text { Cura } \\
\text { (dias) }\end{array}$ & $\begin{array}{c}\text { Resistência à } \\
\text { compressão } \\
\text { diametral } \\
(\mathrm{kPa})\end{array}$ & $\begin{array}{l}\text { Diferença } \\
\quad(\mathrm{kPa})\end{array}$ & $\begin{array}{l}\text { Ganho } \\
\text { resen }\end{array}$ \\
\hline \multirow{10}{*}{ LG' } & \multirow{5}{*}{0} & 0 & 0 & \multirow[t]{2}{*}{ - } & \multirow[t]{2}{*}{-} \\
\hline & & 2 & 107 & & \\
\hline & & 7 & 144 & 37 & 35 \\
\hline & & 28 & 150 & 43 & 40 \\
\hline & & 84 & 181 & 74 & 69 \\
\hline & \multirow{5}{*}{40} & 0 & 0 & \multirow[t]{2}{*}{-} & \multirow[t]{2}{*}{-} \\
\hline & & 2 & 100 & & \\
\hline & & 7 & 115 & 15 & 15 \\
\hline & & 28 & 161 & 61 & 61 \\
\hline & & 84 & 164 & 64 & 64 \\
\hline \multirow{10}{*}{ NG' } & \multirow{5}{*}{0} & 0 & 0 & \multirow[t]{2}{*}{-} & \multirow[t]{2}{*}{-} \\
\hline & & 2 & 93 & & \\
\hline & & 7 & 180 & 87 & 94 \\
\hline & & 28 & 317 & 224 & 241 \\
\hline & & 84 & 351 & 258 & 277 \\
\hline & \multirow{5}{*}{40} & 0 & 0 & \multirow[t]{2}{*}{-} & \multirow[t]{2}{*}{-} \\
\hline & & 2 & 68 & & \\
\hline & & 7 & 119 & 51 & 75 \\
\hline & & 28 & 216 & 148 & 218 \\
\hline & & 84 & 301 & 233 & 343 \\
\hline
\end{tabular}

Nota: Teor de Cal $10 \%$

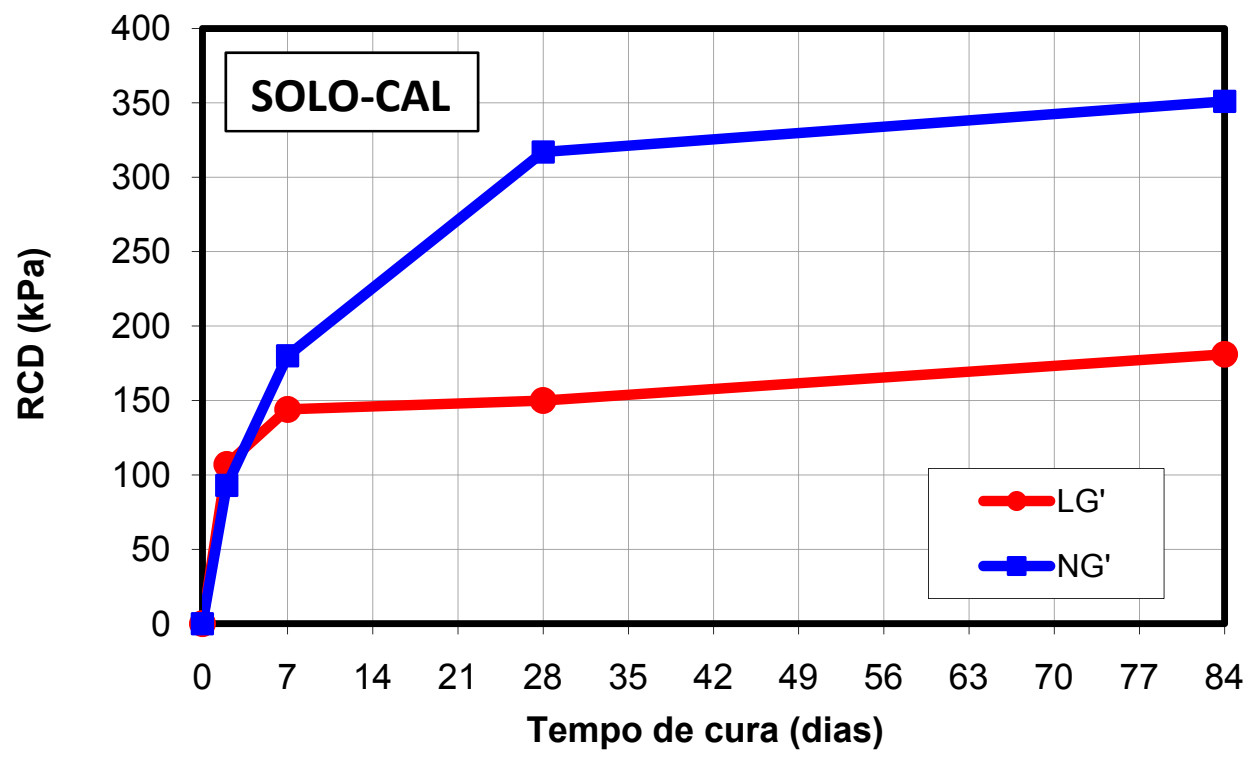

Figura 4.32 - Variação da RCD do solo laterítico (LG') e não-laterítico (NG') com o tempo de cura para misturas com $10 \%$ de cal 


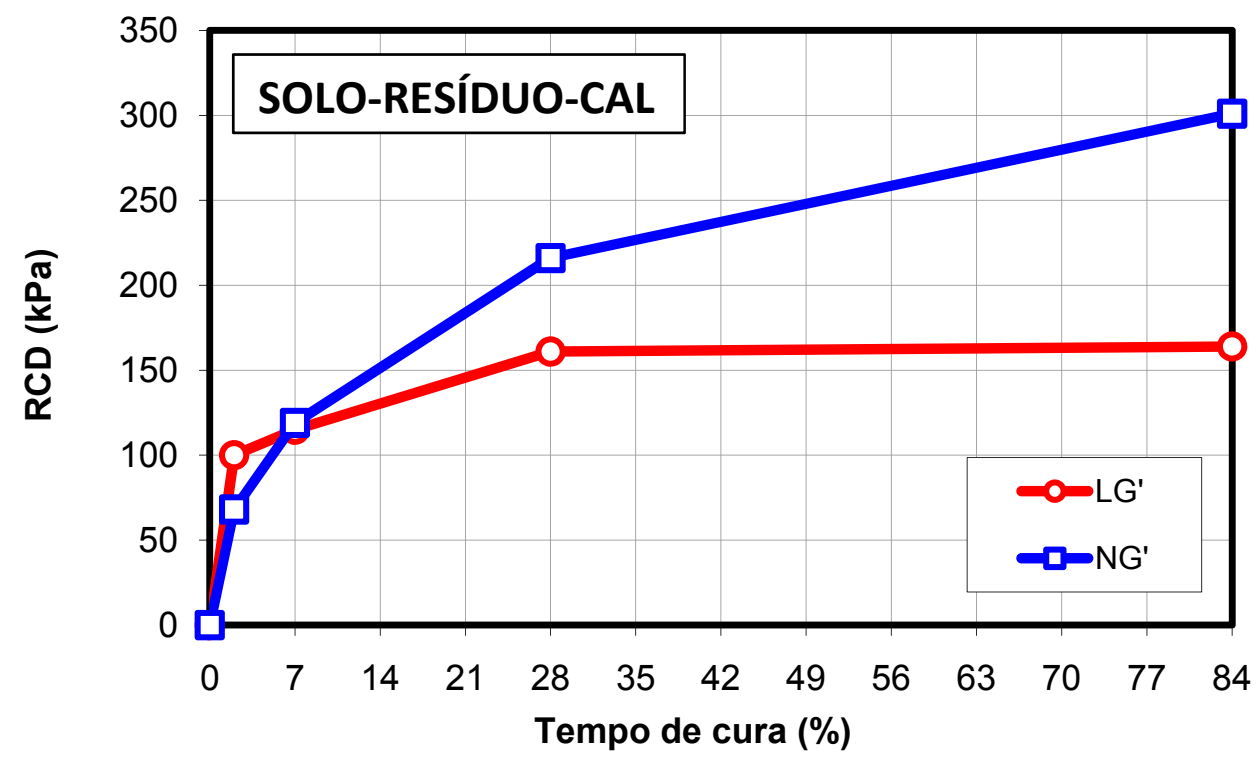

Figura 4.33 - Variação da RCD com o tempo de cura da mistura de resíduo com o solo laterítico (LG') e não-laterítico (NG') para misturas com $10 \%$ de cal

Analisando-se a Figura 4.32, no tocante à influência da gênese dos materiais sem a adição de resíduo, nota-se que para os solos LG' e NG', a taxa da variação da resistência torna-se cada vez menor, mas ainda mostra um gradiente crescente aos 84 dias de cura, não indicando uma estabilização. No tocante ao solo LG', a taxa da variação da resistência à compressão simples, manteve-se estabilizada após os 7 dias de cura, evidenciando para este solo uma maior influencia da ação da cal com o tempo de cura na resistência à tração do que na RCS.

Ainda na Figura 4.32, observa-se que os ganhos de resistência, apresentados na Tabela 4.14, com relação à RCD dos corpos-de-prova dos solos LG' e NG' ensaiados com 2 dias de cura, mostram que estes valores do ganho de resistência para o solo NG' dá-se de maneira efetiva durante um período mais longo que o correspondente ao solo LG'.

Ao se compararem as resistências das misturas constituídas pelos solos LG' e NG' ao longo do período de cura, observa-se que aos 2 dias, os valores são próximos entre si, mas favoráveis ao solo laterítico. Aos 7 dias de cura, ocorre uma inversão e a mistura com o 
solo NG' apresenta resistência superior à do solo LG'. Aos 84 dias, a diferença é de 170 kPa favorável ao solo não-laterítico, para ensaios sem imersão, indicando que este solo é mais reativo à cal que o solo laterítico.

Analisando-se a Figura 4.33, no tocante à influência da gênese dos materiais, notase que a RCD do solo LG' mantêm-se estabilizada após os 28 dias de cura, enquanto para o solo NG', a taxa da variação da resistência torna-se cada vez menor, mas ainda mostra um gradiente crescente aos 84 dias de cura, não indicando uma estabilização.

Ainda na Figura 4.33, observa-se que os ganhos de resistência, apresentados na Tabela 4.14, com relação à RCD dos corpos-de-prova dos solos LG' e NG' ensaiados com 2 dias de cura, mostram que estes valores do ganho de resistência para o solo NG' dá-se de maneira efetiva durante um período mais longo que o correspondente ao solo LG'.

Ao se compararem as resistências das misturas constituídas pelos solos LG' e NG' ao longo do período de cura, observa-se que aos 7 dias, os valores são próximos entre si, favoráveis ao solo não-laterítico. Após os 7 dias de cura o solo NG' continua crescente. Aos 84 dias, a diferença é de 279 kPa favorável ao solo não-laterítico.

Quando se analisam as resistências das misturas de solo-resíduo-cal em relação às misturas de solo-cal ao longo do período de cura, observa-se que a adição do resíduo provocou uma redução, em média, da resistência para todos os tempos de cura, de $6 \%$ e $21 \%$ respectivamente, para os solos LG' e NG'. Observa-se, portanto, que as porcentagens de queda da RCD são inferiores quando comparadas às das RCS, indicando que à ação da cal é mais eficiente quanto à resistência à tração do que à compressão. 


\subsubsection{Influência da imersão em água na resistência à compressão diametral}

Com o propósito de analisar a resistência de camadas de base e sub-base de pavimentos submetidas à influência do aumento de umidade, realizaram-se os ensaios de compressão diametral em corpos-de-prova previamente submetidos à imersão em água por um período de 24 horas, para todas as misturas curadas por 7 dias.

Na Tabela 4.15 são apresentadas as misturas variando-se o teor de cal e de resíduo, apresentando também as RCD, as diferenças e perdas de resistência decorrentes da imersão dos corpos-de-prova em água. As Figuras 4.34 e 4.35 ilustram, respectivamente, para as misturas solo-cal e solo-resíduo-cal, a variação da resistência à compressão diametral em função da imersão em água e teor de cal para corpos-de-prova ensaiados com 7 dias de cura. Observa-se que houve uma redução da RCD quando os corpos-de-prova são ensaiados com imersão e considerando os solos sem cal, observa-se, para ambas as gêneses, que os corpos-de-prova desintegraram-se, não permitindo a realização do ensaio.

Quanto à influência da variação de umidade na RCD dos solos e misturas estudadas sem a adição de resíduo, a Figura 4.34 permite se compararem as resistências de corposde-prova ensaiados sem imersão e após imersão em água. Analisando-se os valores na Tabela 4.15 e a ilustração da Figura 4.34, observa-se que corpos-de-prova ensaiados após imersão apresentam resistências crescentes com o teor de cal, repetindo o comportamento observado anteriormente para corpos-de-prova ensaiados sem imersão. Para as misturas estabilizadas com cal, observa-se para ambas as gêneses, que os corpos-de-prova ficaram estáveis, não se desintegrando, denotando o efeito positivo da ação da cal frente à imersão dos solos. 
Tabela 4.15 - RCD e perdas de resistência das misturas de solo-cal e solo-resíduo-cal para corpos-de-prova ensaiados com imersão em relação aos ensaiados sem imersão em água

\begin{tabular}{|c|c|c|c|c|c|c|}
\hline \multirow{2}{*}{ Tipo de solo } & \multirow{2}{*}{$\begin{array}{c}\text { Teor de } \\
\text { Resíduo } \\
(\%)\end{array}$} & \multirow{2}{*}{$\begin{array}{c}\text { Teor } \\
\text { de Cal } \\
(\%) \\
\end{array}$} & \multicolumn{2}{|c|}{$\mathrm{RCD}(\mathrm{kPa})$} & \multirow{2}{*}{$\begin{array}{c}\text { Diferença } \\
(\mathrm{kPa})\end{array}$} & \multirow{2}{*}{$\begin{array}{c}\text { Perda } \\
(\%)\end{array}$} \\
\hline & & & Sem Imersão & Com Imersão & & \\
\hline \multirow{6}{*}{ LG' } & \multirow{3}{*}{0} & 0 & 23 & 0 & 23 & 100 \\
\hline & & 5 & 92 & 63 & 29 & 32 \\
\hline & & 10 & 144 & 121 & 23 & 16 \\
\hline & \multirow{3}{*}{40} & 0 & 26 & 0 & 26 & 100 \\
\hline & & 5 & 34 & 0 & 34 & 100 \\
\hline & & 10 & 115 & 87 & 28 & 24 \\
\hline \multirow{6}{*}{ NG' } & \multirow{3}{*}{0} & 0 & 34 & 0 & 34 & 100 \\
\hline & & 5 & 80 & 46 & 34 & 43 \\
\hline & & 10 & 180 & 166 & 14 & 8 \\
\hline & \multirow{3}{*}{40} & 0 & 11 & 0 & 11 & 100 \\
\hline & & 5 & 62 & 34 & 28 & 45 \\
\hline & & 10 & 119 & 76 & 43 & 36 \\
\hline
\end{tabular}

Nota: Tempo de Cura 7 dias

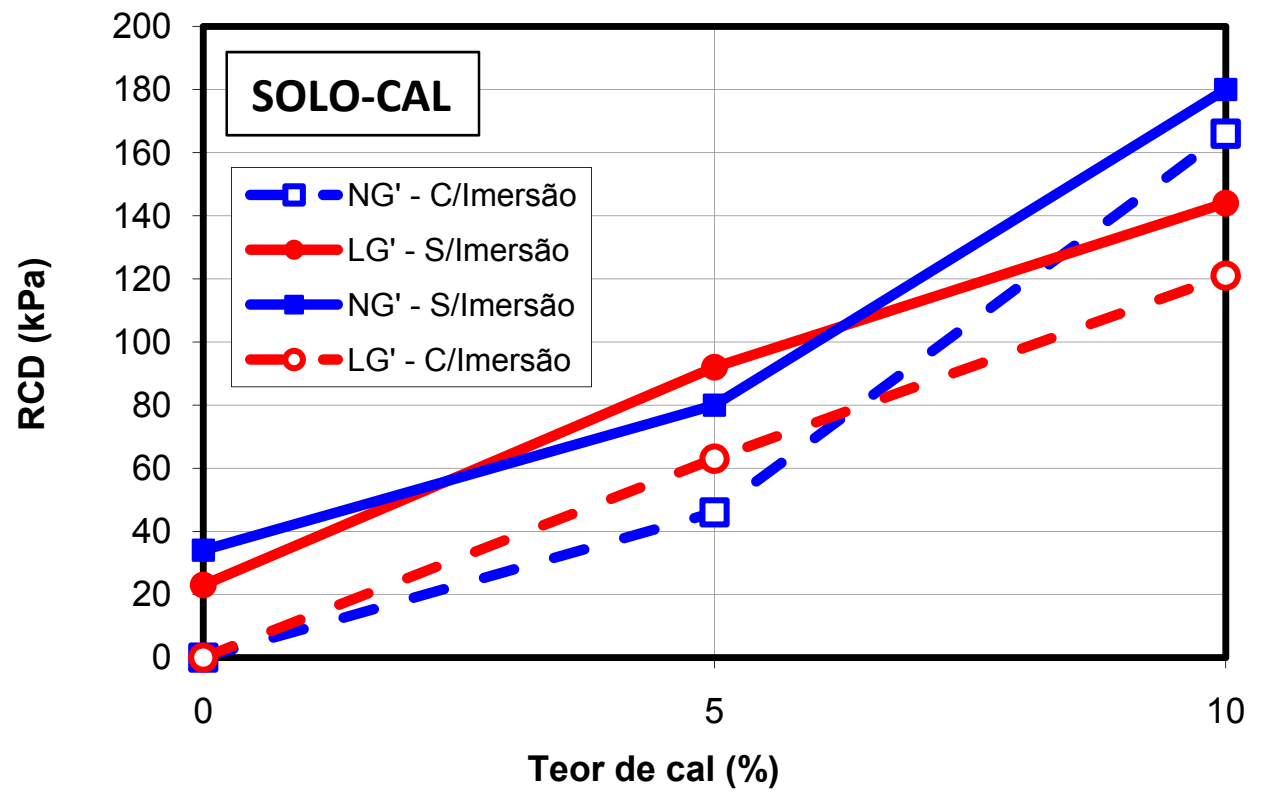

Figura 4.34 - Variação da RCD do solo laterítico (LG') e não-laterítico (NG') com a imersão em água e teor de cal sem adição do resíduo 


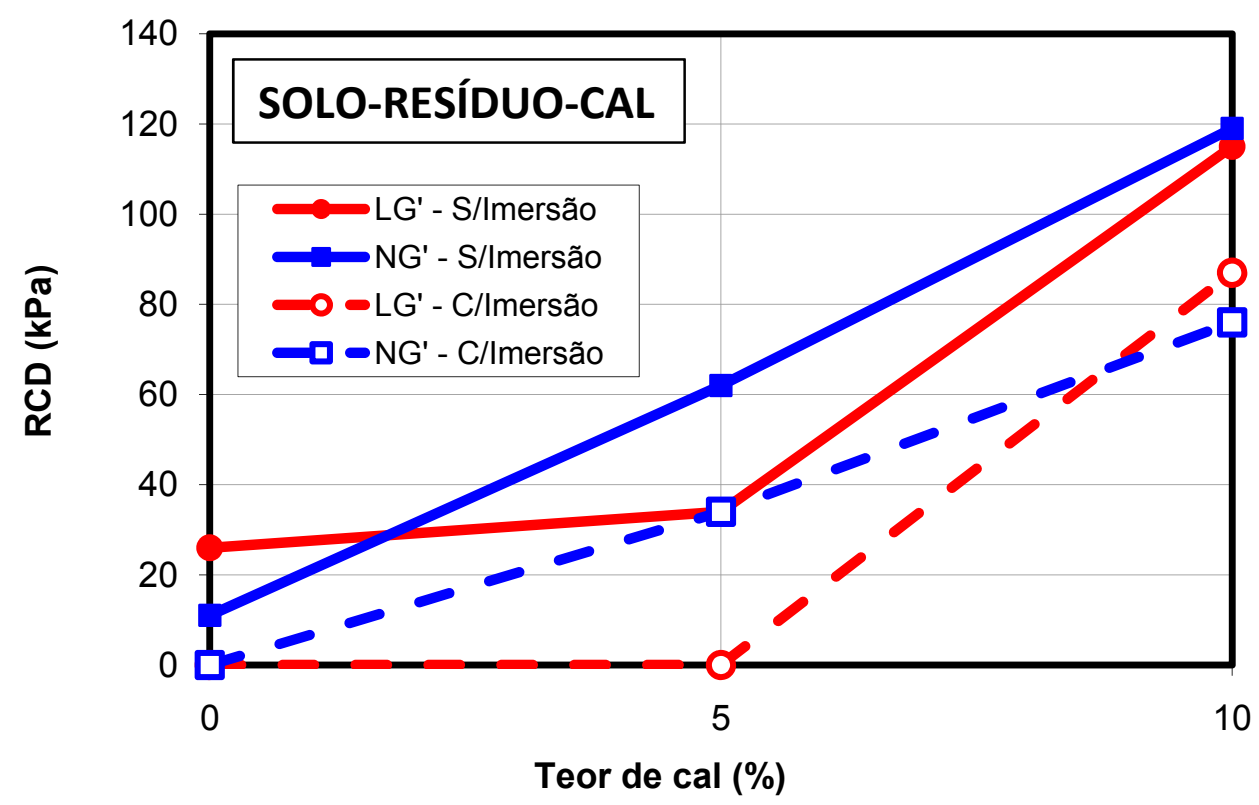

Figura 4.35 - Variação da RCD do solo laterítico (LG') e não-laterítico (NG') com a imersão em água e teor de cal com adição do resíduo

Ainda na Figura 4.34, observa-se que para o teor de $5 \%$ de cal, a perda de resistência devido à imersão é de $32 \%$ e $43 \%$ para os solos LG' e NG', respectivamente. Portanto, para este teor, a menor influência da água sobre o solo laterítico indica que o efeito da gênese sobrepõe-se ao efeito positivo da cal. Para o teor de $10 \%$ de cal, a queda de resistência devido à imersão é de $16 \%$ e $8 \%$ para os solos LG' e NG', indicando que o aumento da quantidade de estabilizante contribui para a redução da suscetibilidade de ambas as misturas à ação da água.

Quando se analisa a perda de resistência devido à imersão em água, ao se aumentar o teor de cal de $5 \%$ para $10 \%$, observa-se que proporcionalmente, o efeito da cal está na relação 2:1 e 5,4:1, respectivamente, para os solos LG' e NG', indicando que para teores mais elevados, a ação da cal é mais efetiva para o solo não-laterítico.

No tocante à influência da variação de umidade na RCD das misturas com a adição de resíduo, a Figura 4.35 permite se compararem as resistências de corpos-de-prova 
ensaiados sem imersão e após imersão em água. Analisando-se os valores da Tabela 4.15 e a ilustração da Figura 4.35, observa-se que corpos-de-prova ensaiados após imersão apresentam resistência crescente com o teor de cal, exceto para o solo LG' ensaiado com imersão e teor de $5 \%$ de cal. Para as misturas estabilizadas com cal se observa para o solo NG' que os corpos-de-prova ficaram estáveis com o teor de $5 \%$ de cal, para o solo LG' esta estabilização dos corpos-de-prova foi obtida apenas para o teor de $10 \%$ de cal.

Ainda na Figura 4.35, observa-se que para o teor de $5 \%$ de cal, a perda de resistência devido à imersão é de $100 \%$ e $45 \%$ para os solos LG' e NG', respectivamente. Portanto, para este teor, a mistura com o solo NG' é menos susceptível à ação da água. Para o teor de $10 \%$ de cal, a perda de resistência devido à imersão é de $24 \%$ e $36 \%$ respectivamente para os solos LG' e NG', indicando que o aumento da quantidade de estabilizante continua contribuindo para a redução da suscetibilidade das misturas de solo e resíduo à ação da água.

Quando se analisa a perda de resistência devida à imersão em água, ao se aumentar o teor de cal de $5 \%$ para $10 \%$, observa-se que proporcionalmente, o efeito da cal está na relação 4,2:1 e 1,3:1, respectivamente para os solos LG' e NG', indicando que a ação da cal nas misturas de solo-resíduo-cal é mais efetiva para o solo laterítico.

Comparando-se o efeito da imersão em água nas misturas solo-cal e solo-resíduocal, observa-se que na RCD, para ambos os solos, as misturas de solo-resíduo-cal são mais susceptíveis à ação da água. A perda de resistência das misturas solo-resíduo-cal em relação às misturas solo-cal, considerando as resistências médias calculadas a partir dos dois teores, é de $64 \%$ e $40 \%$ respectivamente para as misturas compostas com os solos LG' e NG'. 


\subsubsection{Influência do tempo de cura para misturas ensaiadas após imersão em água na resistência à compressão diametral}

Em seguida, para se analisar a influência do aumento da umidade na resistência à compressão diametral ao longo do tempo de cura, foram ensaiadas misturas solo-cal e soloresíduo-cal com 10\% deste estabilizante, curadas por 0, 2, 7, 28 e 84 dias em câmara úmida e ensaiadas após imersão em água por 24 horas.

$\mathrm{Na}$ Tabela 4.16 são apresentados os valores da RCD das misturas de solo-cal e solo-resíduo-cal em função da variação do tempo de cura para copos-de-prova ensaiados com imersão e sem imersão em água, com o teor de $10 \%$ de cal. A diferença e o ganho relativo de resistência dos corpos-de-prova ensaiados com imersão das misturas solo-cal e solo-resíduo-cal ao longo do tempo de cura foram calculadas com relação à resistência aos 2 dias de cura. As Figuras 4.36 e 4.37 ilustram, respectivamente, a variação da resistência à compressão diametral das misturas solo-cal e solo-resíduo-cal em função do tempo de cura e dos corpos-de-prova ensaiados com imersão prévia em água. Observa-se que, no geral, corpos-de-prova ensaiados após imersão em água apresentam um padrão de variação de resistência ao longo do tempo de cura semelhante ao observado anteriormente para as misturas solo-cal e solo-resíduo-cal ensaiadas sem imersão, ou seja, a resistência cresce de maneira mais acentuada no período inicial de 7 dias, destacando-se um maior incremento para as misturas constituídas com o solo NG'.

Analisando-se os valores apresentados na Tabela 4.16 e ilustrados na Figura 4.36, no tocante à influência da gênese dos materiais sem a adição de resíduo, nota-se que para os solos LG' e NG', a taxa da variação da resistência torna-se cada vez menor, mas ainda mostra um gradiente crescente aos 84 dias de cura, não indicando uma estabilização. No tocante ao solo LG', observou-se que a taxa da variação da resistência à compressão 
simples, após 7 dias de cura manteve-se estabilizada, fato não observado na RCD, evidenciando para este solo uma maior influencia da ação da cal com o tempo de cura na resistência à tração do que na RCS.

Tabela 4.16 - Resistência à compressão diametral das misturas e a perda de RCD para corposde-prova ensaiados com imersão e sem imersão em água em função do tempo de cura

\begin{tabular}{|c|c|c|c|c|c|c|}
\hline \multirow{2}{*}{$\begin{array}{l}\text { Tipo de } \\
\text { solo }\end{array}$} & \multirow{2}{*}{$\begin{array}{c}\text { Teor de } \\
\text { Resíduo } \\
\text { (\%) }\end{array}$} & \multirow{2}{*}{$\begin{array}{c}\text { Tempo de } \\
\text { Cura } \\
\text { (Dias) }\end{array}$} & \multicolumn{2}{|c|}{$\mathrm{RCD}(\mathrm{kPa})$} & \multirow{2}{*}{$\begin{array}{l}\text { Diferença } \\
\qquad(\mathrm{kPa})\end{array}$} & \multirow{2}{*}{$\begin{array}{c}\text { Ganho } \\
(\%)\end{array}$} \\
\hline & & & Sem Imersão & Com Imersão & & \\
\hline \multirow{10}{*}{ LG' } & \multirow{5}{*}{0} & 0 & 0 & 0 & & \\
\hline & & 2 & 107 & 69 & - & - \\
\hline & & 7 & 144 & 121 & 52 & 75 \\
\hline & & 28 & 150 & 130 & 61 & 88 \\
\hline & & 84 & 181 & 153 & 84 & 122 \\
\hline & \multirow{5}{*}{40} & 0 & 0 & 0 & & \\
\hline & & 2 & 100 & 63 & - & - \\
\hline & & 7 & 115 & 87 & 24 & 38 \\
\hline & & 28 & 161 & 124 & 61 & 97 \\
\hline & & 84 & 164 & 143 & 80 & 127 \\
\hline \multirow{10}{*}{ NG' } & \multirow{5}{*}{0} & 0 & 0 & 0 & & \\
\hline & & 2 & 93 & 83 & - & - \\
\hline & & 7 & 180 & 166 & 83 & 100 \\
\hline & & 28 & 317 & 292 & 209 & 252 \\
\hline & & 84 & 351 & 332 & 249 & 300 \\
\hline & \multirow{5}{*}{40} & 0 & 0 & 0 & & \\
\hline & & 2 & 68 & 51 & - & - \\
\hline & & 7 & 119 & 76 & 25 & 49 \\
\hline & & 28 & 216 & 152 & 101 & 198 \\
\hline & & 84 & 301 & 212 & 161 & 316 \\
\hline
\end{tabular}




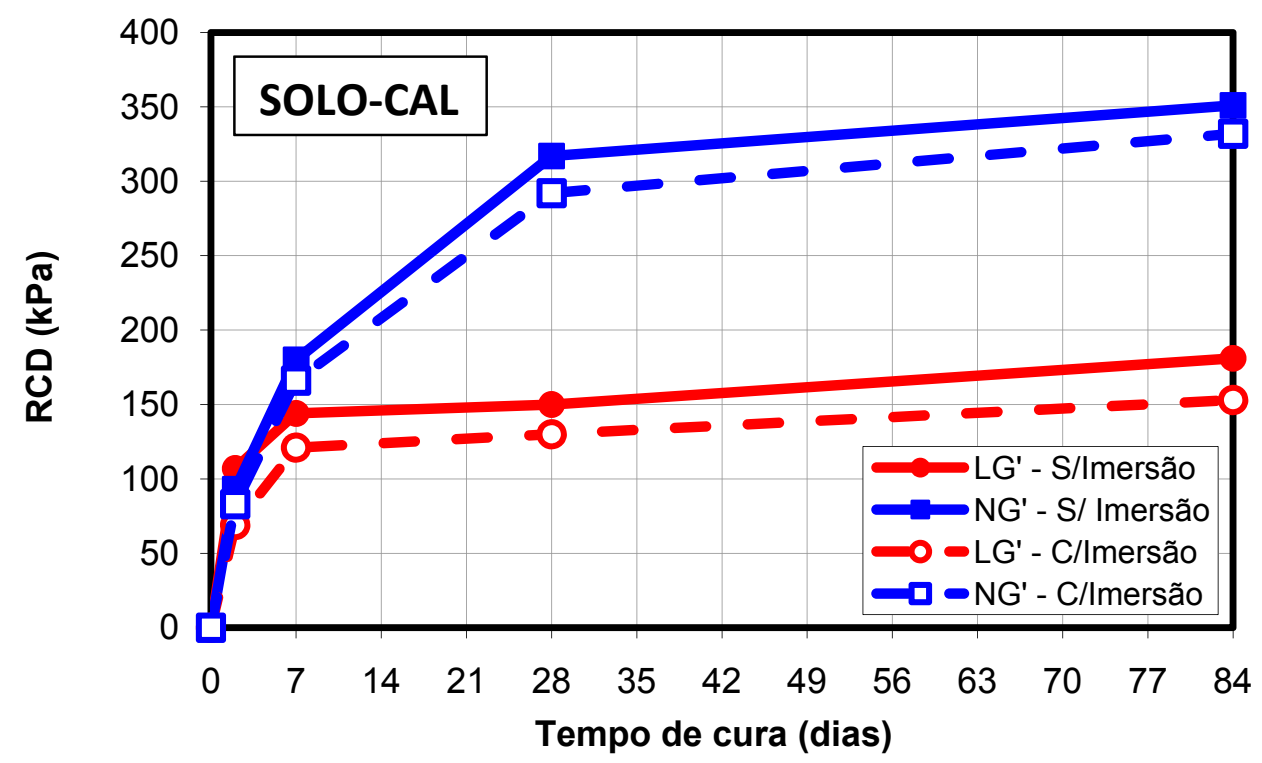

Figura 4.36 - Variação da RCD do solo LG' e NG' com a imersão em água e período de cura sem adição do resíduo

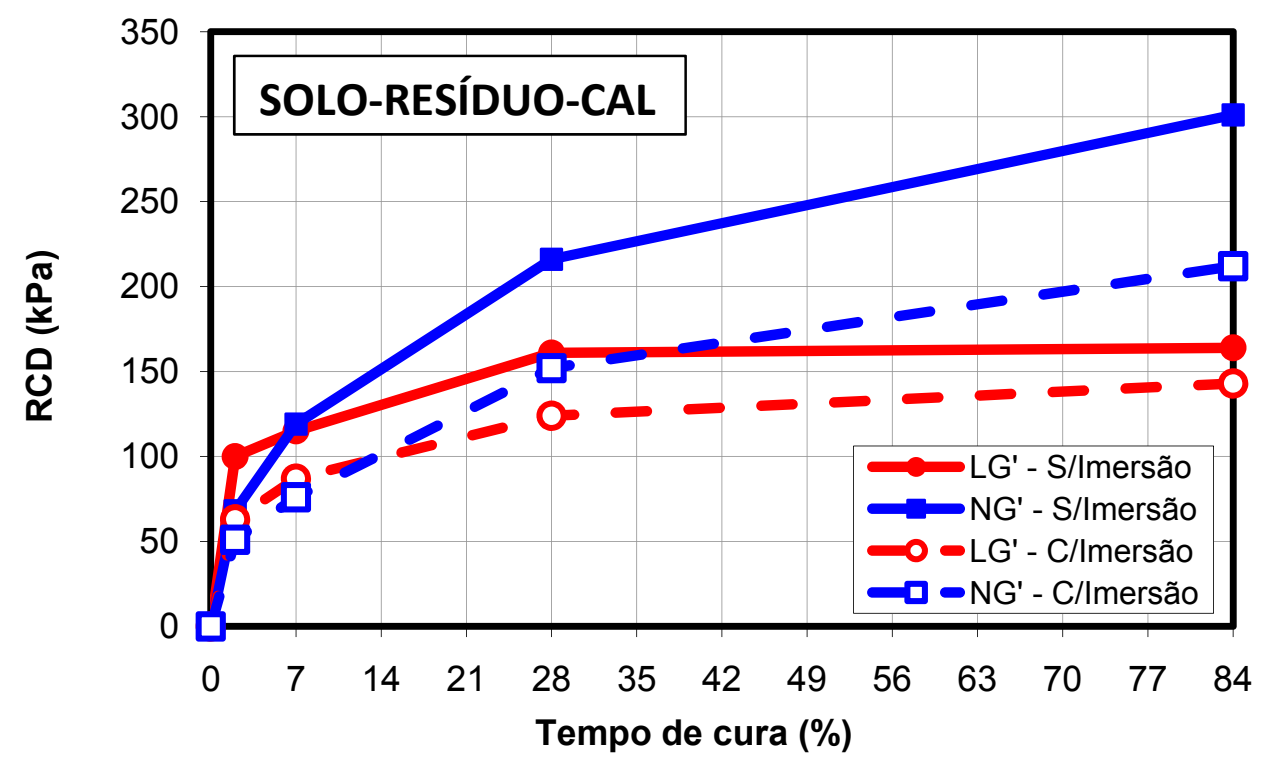

Figura 4.37 - Variação da RCD do solo LG' e NG' com a imersão em água e período de cura com adição do resíduo

Ainda na Figura 4.36, observa-se um ganho de resistência com relação à $R C D$ dos corpos-de-prova dos solos LG' e NG' ensaiados com 2 dias de cura, de respectivamente $75 \%$ e $100 \%$ aos 7 dias, de $88 \%$ e $252 \%$ aos 28 dias, e de $122 \%$ e $300 \%$ aos 84 dias. Estes valores mostram que o ganho de resistência para o solo NG' dá-se de maneira efetiva 
durante um período mais longo que o correspondente ao solo LG'. Ao se compararem as resistências das misturas constituídas pelos solos LG' e NG' ao longo do período de cura, observa-se que aos 2 dias, os valores são próximos entre si, mas favoráveis ao solo nãolaterítico. Aos 84 dias, a diferença é de $179 \mathrm{kPa}$, ou seja, a RCD com o solo NG' é $54 \%$ superior à mistura com o solo LG', para ensaios com imersão, indicando que o solo nãolaterítico é mais reativo à cal que o solo laterítico.

Ainda na Figura 4.36, para corpos-de-prova ensaiados após imersão em água, ao se compararem as perdas de resistências das misturas solo-cal constituídas pelos solos LG' e NG' ao longo do período de cura em relação às misturas ensaiadas sem imersão, observase que as misturas constituídas com o solo argiloso laterítico adquirem uma estabilização aos 7 dias de cura, observando-se para este solo perdas médias de resistência de $15 \%$. Para as misturas constituídas com o solo NG', observa-se que esta estabilização dá-se já aos 2 dia de cura, obtendo-se perdas médias de resistência de 7\%. Comparando-se as misturas compostas pelos dois solos, observa-se que o solo LG' se mostra mais susceptível à ação da água quando comparado às misturas solo-cal constituídas com o solo NG'.

Analisando-se os valores apresentados na Tabela 4.16 e ilustrados na Figura 4.37 observa-se para as misturas solo-resíduo-cal que as resistências dos corpos-de-prova do solo LG' ensaiados com imersão não apresentam o comportamento observado anteriormente para corpos-de-prova ensaiados sem imersão, mantendo-se estabilizada a RCD após os 28 dias de cura, enquanto para o solo NG', a taxa de variação da resistência torna-se cada vez menor, mas ainda mostrando-se com um gradiente crescente aos 84 dias de cura, não indicando uma estabilização.

Observa-se na Figura 4.37, para corpos-de-prova ensaiados após imersão em água, ao se compararem as resistências das misturas constituídas pelos solos LG' e NG' ao longo do período de cura, que aos 2 dias, o solo laterítico apresenta resistência $24 \%$ superior a do 
solo NG'. Após os 7 dias de cura, ocorre uma inversão e a mistura com o solo NG' apresenta resistência superior à do solo LG'. Aos 84 dias, a diferença de resistência da mistura com o solo NG' é de $69 \mathrm{kPa}$, ou seja, a RCD é $33 \%$ superior a mistura com o solo laterítico, mostrando que há uma melhor ação cimentante da cal para solos argilosos nãolateríticos que possuam uma granulometria mais grossa. Desta forma, observa-se que a cal age na RCD de melhor forma ao longo do tempo de cura.

Ainda na Figura 4.37, para corpos-de-prova ensaiados após imersão em água, ao se compararem as perdas de resistências das misturas solo-resíduo-cal constituídas pelos solos LG' e NG' ao longo do período de cura em relação às misturas ensaiadas sem imersão, observa-se que as misturas constituídas com o solo argiloso laterítico adquirem uma estabilização aos 7 dias de cura, observa-se para este solo perdas médias de resistência de $20 \%$. Para as misturas constituídas com o solo NG', observa-se que esta estabilização dar-se já aos 2 dia de cura, obtendo-se perdas médias de resistência de $30 \%$. Comparando-se as misturas compostas pelos dois solos, observa-se que apesar da rápida estabilização da mistura com o solo NG', esta se mostra mais susceptível à ação da água quando comparado às misturas solo-resíduo-cal constituídas com o solo LG'.

Ao se compararem as resistências após imersão de misturas solo-cal e solo-resíduocal, observa-se que as misturas solo-cal, considerando as resistências médias calculadas a partir dos tempos de cura estudados, apresentam resistências $50 \%$ e $23 \%$ superiores as misturas de solo-resíduo-cal, respectivamente para as misturas constituídas com o solo LG' e NG', concluindo-se que quanto à gênese, as misturas compostas com o solo NG', adquirem resistências mais elevadas ao longo do tempo de cura em relação às misturas constituídas com o solo LG'.

Finalmente, quando se comparam as perdas de resistência das misturas solo-cal em relação às misturas solo-resíduo-cal, observa-se que para as misturas constituídas com o 
solo LG' a perda de resistência, considerando as perdas após sua estabilização, ou seja, a partir dos 7 dias de cura, é de $15 \%$ e $20 \%$, respectivamente, para as misturas solo-cal e solo-resíduo-cal. Conclui-se, portanto, que as misturas apresentam perdas semelhantes, ou seja, o resíduo na mistura apresenta pouca influência na susceptibilidade da RCD à ação da água. Para as misturas constituídas com o solo NG', considerando as perdas após sua estabilização, ou seja, a partir dos 2 dias de cura, observam-se perdas de $8 \%$ e $30 \%$, respectivamente, para misturas solo-cal e solo-resíduo-cal, concluindo-se que as misturas solo-resíduo-cal são mais susceptíveis à ação da água quando comparadas às misturas solo-cal.

\subsubsection{Ensaio triaxial cíclico}

Os resultados dos ensaios triaxiais cíclicos forneceram subsídios para avaliar o comportamento das misturas de solo-cal e solo-resíduo-cal através da análise do módulo de resiliência $\left(M_{R}\right)$, considerando-se a influência, nesta variável, do teor de cal e tipo de solo incorporado à mistura.

Conforme apresentado no Capítulo 3, foram ensaiadas misturas de solo-cal e soloresíduo-cal estabilizadas com 5 e $10 \%$ de cal. Para os ensaios triaxiais cíclicos, foram ensaiados corpos-de-prova sem imersão prévia em água e após 7 dias de cura em câmara úmida. Os corpos-de-prova foram compactados na umidade ótima e massa específica seca máxima na energia equivalente ao Proctor normal. 


\subsubsection{Modelagem do $M_{R}$ em função do estado de tensão}

A avaliação da variação do $M_{R}$ com o estado de tensão realizou-se através da calibração de quatro modelos matemáticos. Realizaram-se regressões múltiplas nãolineares através do processamento de dados pelo programa STATISTICA 8.0, utilizando-se como variável dependente o módulo de resiliência e como variáveis independentes as tensões confinantes e desvio. Examinou-se o coeficiente de determinação $\left(R^{2}\right)$ com o propósito de se observar os melhores modelos matemáticos. Os quatro modelos utilizados levam em conta a tensão confinante (Eq. 4.1), a tensão desvio (Eq. 4.2), as tensões desvio e confinante simultaneamente, "modelo composto" (Eq. 4.3) e o primeiro invariante de tensões e a tensão octaédrica cisalhante simultaneamente, "modelo universal da AASTHO" (Eq. 4.4).

$$
\begin{gathered}
M_{R}=\mathrm{k}_{1} \cdot \sigma_{3}^{k_{2}} \\
M_{R}=\mathrm{k}_{1} \cdot \sigma_{d}^{k_{2}} \\
M_{R}=\mathrm{k}_{1} \cdot \sigma_{3}^{k_{2}} \cdot \sigma_{d}^{k_{3}} \\
M_{R}=\mathrm{k}_{1} \cdot p_{a}\left(\frac{\theta}{p_{a}}\right)^{k_{2}} \cdot\left(\frac{\tau_{o c t}}{p_{a}}+1\right)^{k_{3}}
\end{gathered}
$$

onde:

$M_{R}$ : módulo de resiliência (MPa);

$\sigma_{d}$ : tensão desvio $(\mathrm{kPa})$;

$\sigma_{3}$ : tensão confinante $(\mathrm{kPa})$;

$\theta$ : primeiro invariante de tensão $(\mathrm{kPa})$;

$\tau_{\text {oct }}:$ tensão cisalhante octaédrica $(\mathrm{kPa})$;

$P_{a}$ : pressão atmosférica $(\mathrm{kPa})$;

$k_{1}, k_{2}, k_{3}$ : parâmetros de regressão. 


\subsubsection{Módulo de resiliência das misturas de solo-cal}

A Tabela 4.17 apresenta os valores do $M_{R}$ para as misturas compostas com os solos LG' e NG', estabilizadas com 5 e 10\% de cal, considerando-se os estágios de aplicação de carga preconizados na norma TP - 46-94. Ainda na Tabela 4.17, os valores tachados não foram utilizados como dados para calibrar os modelos apresentados. Em seguida, a Tabela 4.18 mostra os valores dos parâmetros de regressão e os coeficientes de determinação $R^{2}$ para cada um dos modelos analisados. As Figuras 4.38, 4.39, 4.40 e 4.41 ilustram tridimensionalmente o comportamento resiliente das misturas solo-cal estudadas a partir do modelo em questão.

TABELA 4.17 - Valores dos módulos de resiliência da mistura de solo-cal com 5 e $10 \%$ de cal e ensaiada sem imersão prévia

\begin{tabular}{ccccccccc}
\hline \multirow{2}{*}{ Seqüência } & \multicolumn{4}{c}{ Tensões } & \multicolumn{5}{c}{ MR (MPa) } \\
\cline { 2 - 8 } & $\begin{array}{c}\sigma_{3} \\
(\mathrm{kPa})\end{array}$ & $\begin{array}{c}\sigma_{1} \\
\mathrm{kPa})\end{array}$ & $\begin{array}{c}\sigma_{\mathrm{d}} \\
(\mathrm{kPa})\end{array}$ & $\begin{array}{c}\sigma_{\text {cont. }} \\
(\mathrm{kPa})\end{array}$ & $5 \%$ Cal & $10 \%$ Cal & $5 \%$ Cal & $10 \%$ Cal \\
\hline 1 & & 24,3 & 22,2 & 2,1 & 692 & 1979 & 561 & 1017 \\
2 & 20,7 & 47,7 & 43,6 & 4,1 & 540 & 4411 & 366 & 1819 \\
3 & & 74,3 & 68,1 & 6,2 & 438 & 5126 & 468 & 4657 \\
\hline 4 & & 41,8 & 38,3 & 3,5 & 584 & 3997 & 327 & 1525 \\
5 & 34,5 & 82,1 & 75,2 & 6,9 & 450 & 4070 & 436 & 2716 \\
6 & & 125,8 & 115,5 & 10,3 & 402 & 1859 & 367 & 2842 \\
\hline 7 & & 62,5 & 57,2 & 5,3 & 503 & 4852 & 434 & 4147 \\
8 & 52,5 & 126,3 & 115,8 & 10,5 & 439 & 4579 & 377 & 2956 \\
9 & & 188,8 & 173,0 & 15,8 & 427 & 1712 & 354 & 3148 \\
\hline 10 & & 83,3 & 76,4 & 6,9 & 498 & 2918 & 424 & 2740 \\
11 & 68,9 & 165,3 & 151,5 & 13,8 & 464 & 1799 & 382 & 2855 \\
12 & & 243,2 & 222,5 & 20,7 & 448 & 1672 & 351 & 2918 \\
\hline 13 & & 83,6 & 76,7 & 6,9 & 575 & 2455 & 460 & 4903 \\
14 & 103,4 & 128,5 & 118,2 & 10,3 & 538 & 2020 & 409 & 3352 \\
15 & & 251,9 & 231,2 & 20,7 & 506 & 1681 & 365 & 3056 \\
\hline 16 & & 128,7 & 118,4 & 10,3 & 617 & 2188 & 433 & 3171 \\
17 & 137,9 & 168,7 & 154,9 & 13,8 & 616 & 1873 & 423 & 3027 \\
18 & & 304,7 & 277,1 & 27,6 & 483 & 1395 & 442 & 2557 \\
\hline
\end{tabular}


TABELA 4.18 - Parâmetros de regressão e coeficientes de determinação para as equações $4.1,4.2,4.3$ e 4.4

\begin{tabular}{|c|c|c|c|c|c|c|c|c|c|}
\hline \multirow{2}{*}{$\begin{array}{c}\text { Teor } \\
\text { de } \\
\text { cal } \\
(\%)\end{array}$} & \multirow{2}{*}{ Modelo } & \multicolumn{4}{|c|}{ Solo LG' } & \multicolumn{4}{|c|}{ Solo NG' } \\
\hline & & $\mathbf{k}_{1}$ & $k_{2}$ & $\mathbf{k}_{3}$ & $\mathbf{R}^{2}$ & $\mathbf{k}_{1}$ & $k_{2}$ & $k_{3}$ & $\mathbf{R}^{2}$ \\
\hline \multirow{4}{*}{5} & $M_{R}=\mathrm{k}_{1} \cdot \sigma_{3}^{k_{2}}$ & 216 & 0,194 & - & 0,78 & 240 & 0,118 & - & 0,65 \\
\hline & $M_{R}=\mathrm{k}_{1} \cdot \sigma_{d}^{k_{2}}$ & 1002 & $-0,152$ & - & 0,73 & 1002 & $-0,191$ & - & 0,91 \\
\hline & $M_{R}=\mathrm{k}_{1} \cdot \sigma_{3}^{k_{2}} \cdot \sigma_{d}^{k_{3}}$ & 348 & 0,262 & $-0,160$ & 0,93 & 942 & 0,053 & $-0,225$ & 0,93 \\
\hline & $M_{R}=\mathrm{k}_{1}\left(p_{a}\right) \cdot\left(\frac{\theta}{p_{a}}\right)^{k_{2}} \cdot\left(\frac{\tau_{o c t}}{p_{a}}+1\right)^{k_{3}}$ & 530 & 0,202 & $-0,272$ & 0,84 & 832 & 0,024 & $-0,210$ & 0,91 \\
\hline \multirow{4}{*}{10} & $M_{R}=\mathrm{k}_{1} \cdot \sigma_{3}^{k_{2}}$ & 24889 & $-0,560$ & - & 0,82 & 925 & 0,254 & - & 0,68 \\
\hline & $M_{R}=\mathrm{k}_{1} \cdot \sigma_{d}^{k_{2}}$ & 47101 & $-0,630$ & - & 0,90 & 763 & 0,264 & - & 0,76 \\
\hline & $M_{R}=\mathrm{k}_{1} \cdot \sigma_{3}^{k_{2}} \cdot \sigma_{d}^{k_{3}}$ & 52087 & $-0,300$ & $-0,390$ & 0,91 & 711 & 0,083 & 0,207 & 0,77 \\
\hline & $M_{R}=\mathrm{k}_{1}\left(p_{a}\right) \cdot\left(\frac{\theta}{p_{a}}\right)^{k_{2}} \cdot\left(\frac{\tau_{o c t}}{p_{a}}+1\right)^{k_{3}}$ & 37765 & $-0,070$ & $-0,610$ & 0,90 & 877 & 0,013 & 0,261 & 0,76 \\
\hline
\end{tabular}

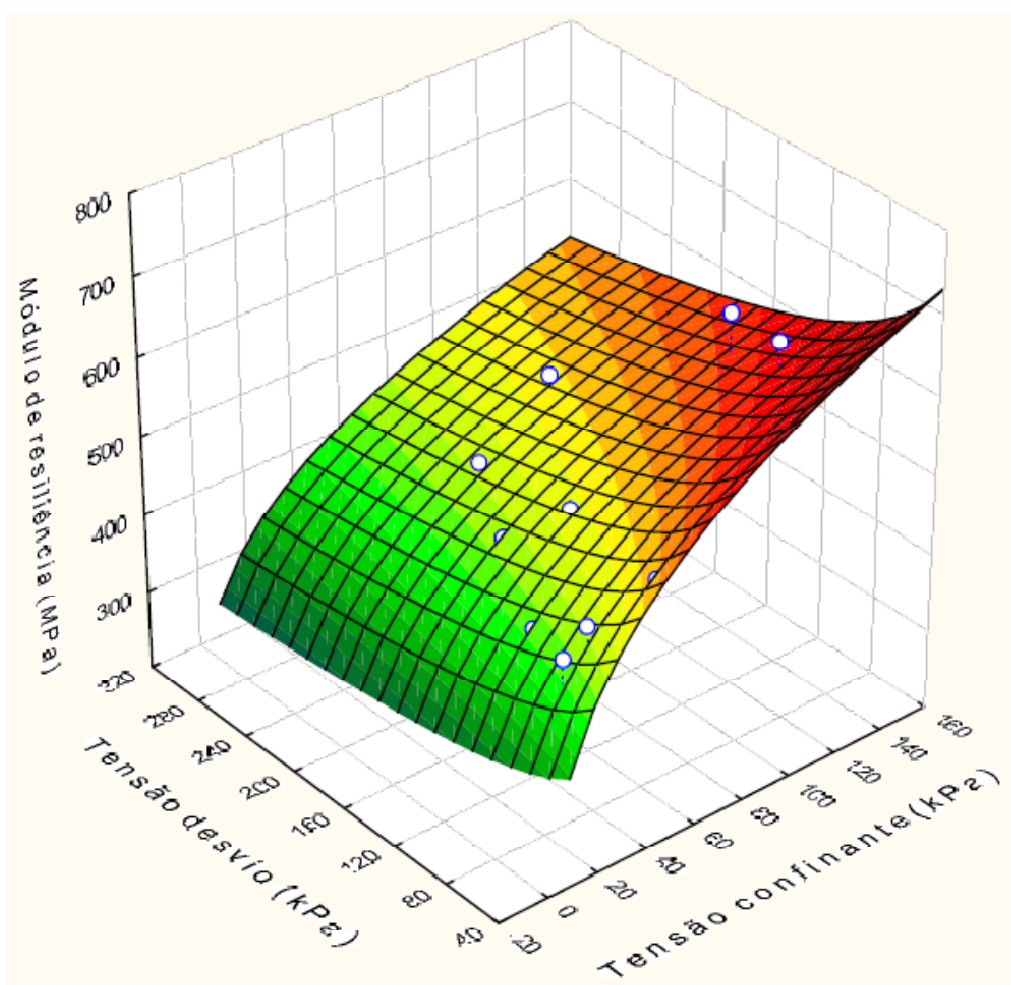

Figura 4.38 - Representação tridimensional do modelo composto para o solo LG' com $5 \%$ de cal 


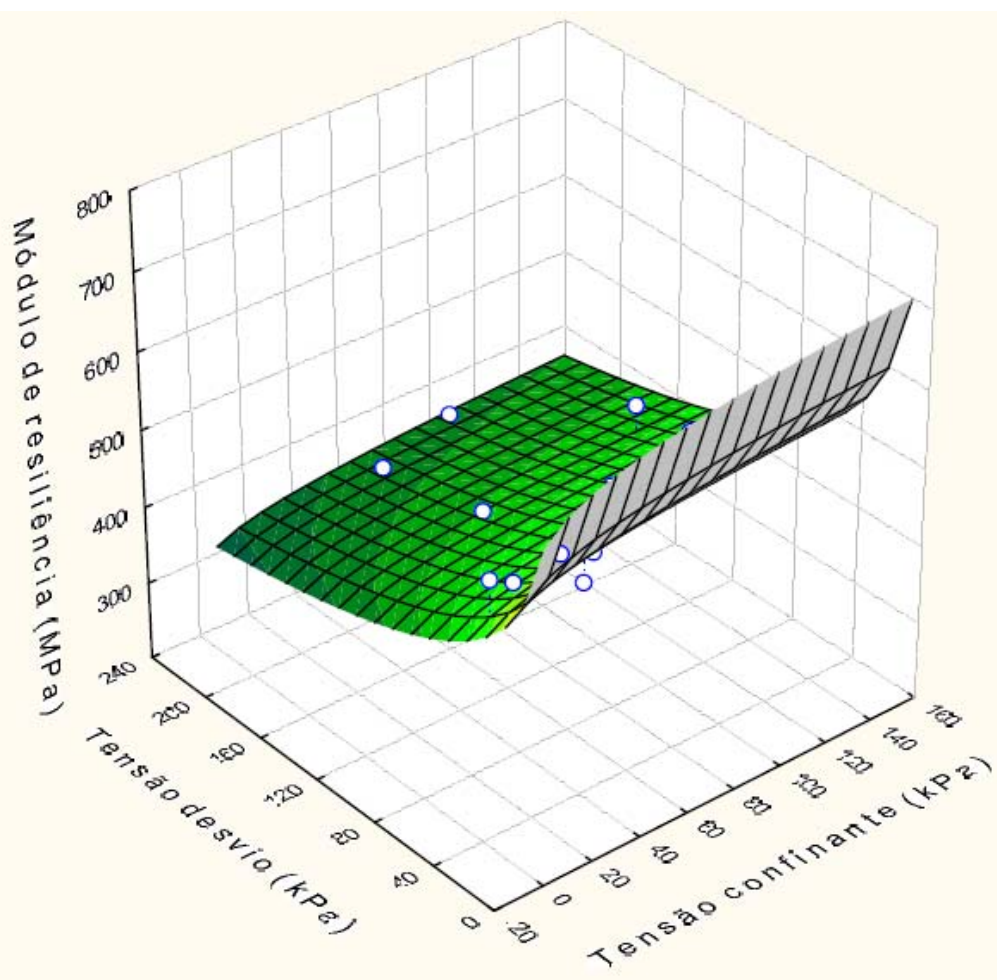

Figura 4.39 - Representação tridimensional do modelo composto para o solo NG' com $5 \%$ de cal

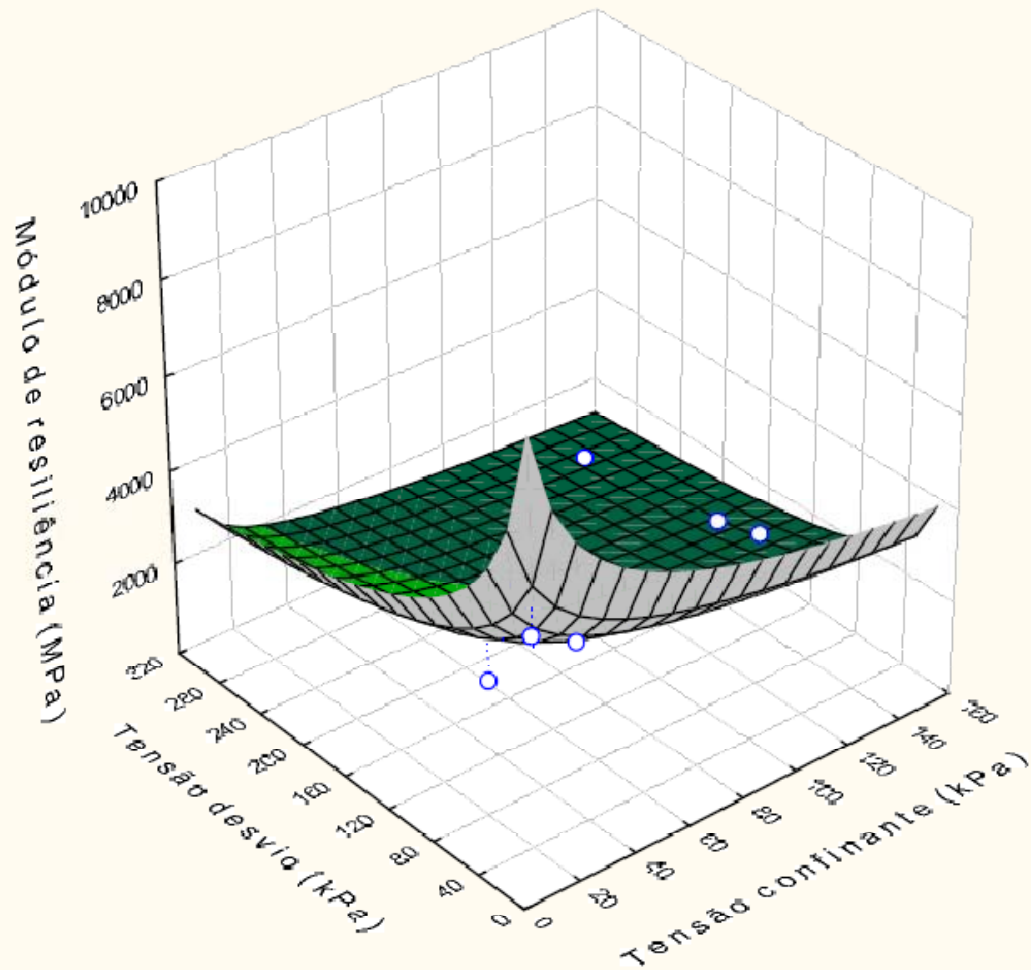

Figura 4.40 - Representação tridimensional do modelo composto para o solo LG' com $10 \%$ de cal 


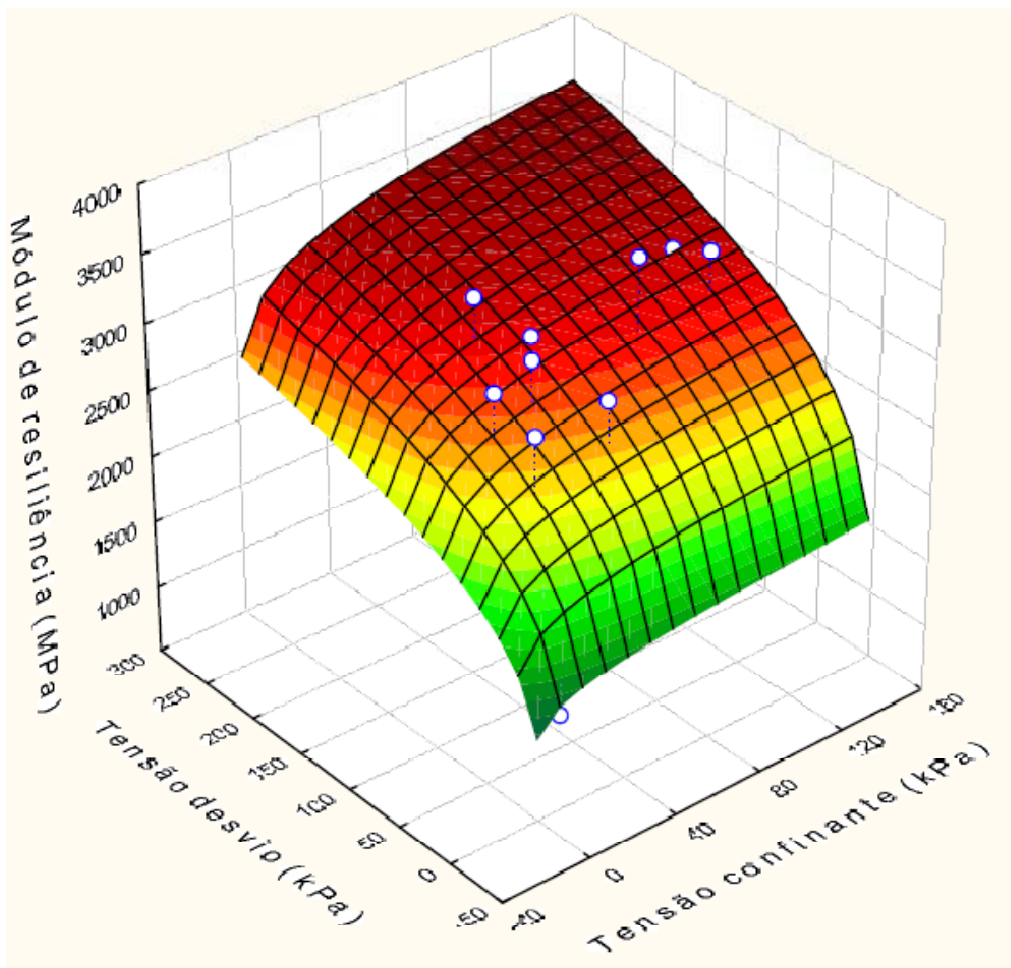

Figura 4.41 - Representação tridimensional do modelo composto para o solo NG' com $10 \%$ de cal

Analisando-se os coeficientes de regressão $\left(R^{2}\right)$ e tomando-os como medidas da adaptação dos modelos para representar a variação do módulo de resiliência em função do estado de tensão para ambos os solos e teores de cal estudados, observou-se, de maneira geral, que as expressões 4.3 e 4.4 mostram-se as mais satisfatórias para a representação do módulo de resiliência. Entretanto, das duas expressões, a 4.3 apresenta melhor desempenho. Portanto, devido a este fato e à tendência observada no Brasil de se privilegiar esta expressão, as análises seguintes foram efetuadas com base neste modelo.

Analisando-se a Tabela 4.18 e as ilustrações das Figuras 4.38 e 4.39, observa-se para as misturas dos solos LG' e NG' com $5 \%$ de cal, que os coeficientes $k_{2}$ e $k_{3}$ são positivos e negativos, respectivamente. Este comportamento repete o comportamento esperado para materiais geotécnicos, onde o aumento das tensões confinante e desvio levam ao aumento e ao decréscimo, respectivamente, do $M_{R}$. Comportamento similar foi observado por Parente (2002) para bases estabilizadas com 4\% de cimento. Ainda para 
estas misturas, comparando-se os valores de $k_{2}$ e $k_{3}$ e considerando-se que as variações das tensões confinantes e desvio são de mesma ordem, pode-se afirmar que $\circ M_{R}$ das misturas com o solo LG' é influenciado pela variação de ambas as tensões. Para a mistura com o solo NG', observa-se que o valor de $k_{3}$ é 4,2 vezes mais que o valor de $k_{2}$, indicando que a influência da tensão desvio na variação do $M_{R}$ sobrepõe-se à influência da tensão confinante, comportamento típico dos solos finos, destacando-se ainda que o valor de $\mathrm{k}_{2}$ muito pequeno indica que a influência de $\sigma_{3}$ é mínima para esta mistura.

Analisando-se a Tabela 4.18 e as ilustrações das Figuras 40 e 41, observa-se para as misturas com o solo LG' com $10 \%$ de cal, que o valor de $k_{2}$, anteriormente positivo, tornase negativo, e que o sinal de $k_{3}$ mantém-se negativo. Isto indica que o aumento das tensões confinante e desvio acarretam a diminuição do $M_{R}$. Este comportamento também foi observado por Parente (2002) para uma mistura solo-cimento composta com um solo NA', ao se aumentar o teor de cimento de 4 para $7 \%$, aos 7 dias de cura. Observa-se ainda que os valores de $k_{2}$ e $k_{3}$ são da mesma ordem de grandeza, indicando que ambas as tensões têm influência expressiva no valor do $M_{R}$. Para as misturas compostas com o solo NG' e $10 \%$ de cal, observa-se que o valor de $\mathrm{k}_{2}$ mantém-se positivo, mas pouco elevado, tal como ocorrera para $5 \%$ de cal. Este fato indica que a influência da tensão confinante é positiva, mas pouco expressiva. Para $k_{3}$, ao se aumentar o teor de cal de 5 para $10 \%$, o valor, anteriormente negativo, torna-se positivo, ou seja, o aumento da tensão desvio acarreta o aumento do $M_{R}$. Este comportamento é atípico, e não se encontrou na revisão bibliográfica, materiais com comportamento semelhante. Pode-se observar ainda para este solo que o valor de $k_{3}$ é 2,5 vezes mais que o valor de $k_{2}$, indicando que a influência da tensão desvio na variação do $M_{R}$ sobrepõe-se à influência da tensão confinante. 


\subsubsection{Módulo de resiliência das misturas de solo-resíduo-cal}

A Tabela 4.19 apresenta os valores do $M_{R}$ para as misturas compostas com os solos LG' e NG', estabilizadas com 5 e 10\% de cal, considerando-se os estágios de aplicação de carga preconizados na norma TP - 46-94. Ainda na Tabela 4.19, os valores tachados não foram utilizados como dados para calibrar os modelos apresentados. Em seguida, a Tabela 4.20 mostra os valores dos parâmetros de regressão e os coeficientes de determinação $R^{2}$ para cada um dos modelos analisados. As Figuras 4.42, 4.43, 4.44 e 4.45 ilustram tridimensionalmente o comportamento resiliente das misturas solo-resíduo-cal estudadas a partir do modelo em questão.

TABELA 4.19 - Valores dos módulos de resiliência da mistura de solo-resíduo-cal com 5 e $10 \%$ de cal e ensaiada sem imersão prévia

\begin{tabular}{ccccccccc}
\hline & \multicolumn{3}{c}{ Tensões } & \multicolumn{4}{c}{ MR (MPa) } \\
\cline { 2 - 9 } Seqüência & $\begin{array}{c}\sigma_{3} \\
(\mathrm{kPa})\end{array}$ & $\begin{array}{c}\sigma_{1} \\
(\mathrm{kPa})\end{array}$ & $\begin{array}{c}\sigma_{\mathrm{d}} \\
(\mathrm{kPa})\end{array}$ & $\begin{array}{c}\sigma_{\text {cont. }} \\
(\mathrm{kPa})\end{array}$ & $5 \%$ Cal & $10 \%$ Cal & $5 \%$ Cal & $10 \%$ Cal \\
\hline 1 & & 24,3 & 22,2 & 2,1 & 467 & 1057 & 516 & 1559 \\
2 & 20,7 & 47,7 & 43,6 & 4,1 & 348 & 1363 & 469 & 1214 \\
3 & & 74,3 & 68,1 & 6,2 & 323 & 952 & 420 & 1204 \\
\hline 4 & & 41,8 & 38,3 & 3,5 & 378 & 1451 & 463 & 1182 \\
5 & 34,5 & 82,1 & 75,2 & 6,9 & 335 & 998 & 428 & 1257 \\
6 & & 125,8 & 115,5 & 10,3 & 304 & 801 & 400 & 1304 \\
\hline 7 & & 62,5 & 57,2 & 5,3 & 370 & 1340 & 446 & 1392 \\
8 & 52,5 & 126,3 & 115,8 & 10,5 & 330 & 871 & 407 & 1372 \\
9 & & 188,8 & 173,0 & 15,8 & 323 & 802 & 396 & 1359 \\
\hline 10 & & 83,3 & 76,4 & 6,9 & 381 & 959 & 419 & 1353 \\
11 & 68,9 & 165,3 & 151,5 & 13,8 & 343 & 874 & 411 & 1385 \\
12 & & 243,2 & 222,5 & 20,7 & 329 & 801 & 387 & 1361 \\
\hline 13 & & 83,6 & 76,7 & 6,9 & 418 & 1131 & 436 & 1325 \\
14 & 103,4 & 128,5 & 118,2 & 10,3 & 393 & 926 & 423 & 1336 \\
15 & & 251,9 & 231,2 & 20,7 & 356 & 822 & 389 & 1371 \\
\hline 16 & & 128,7 & 118,4 & 10,3 & 425 & 952 & 443 & 1397 \\
17 & 137,9 & 168,7 & 154,9 & 13,8 & 416 & 898 & 438 & 1399 \\
18 & & 304,7 & 277,1 & 27,6 & 316 & 672 & 332 & 1143 \\
\hline
\end{tabular}


TABELA 4.20 - Parâmetros de regressão e coeficientes de determinação para as equações $4.1,4.2,4.3$ e 4.4

\begin{tabular}{|c|c|c|c|c|c|c|c|c|c|}
\hline \multirow{2}{*}{$\begin{array}{c}\text { Teor } \\
\text { de } \\
\text { cal } \\
(\%)\end{array}$} & \multirow{2}{*}{ Modelo } & \multicolumn{4}{|c|}{ Solo LG' } & \multicolumn{4}{|c|}{ Solo NG' } \\
\hline & & $\mathbf{k}_{1}$ & $\mathbf{k}_{2}$ & $\mathbf{k}_{3}$ & $\mathbf{R}^{2}$ & $\mathbf{k}_{1}$ & $\mathbf{k}_{2}$ & $\mathbf{k}_{3}$ & $\mathbf{R}^{2}$ \\
\hline \multirow{4}{*}{5} & $M_{R}=\mathrm{k}_{1} \cdot \sigma_{3}^{k_{2}}$ & 202 & 0,140 & - & 0,76 & 657 & $-0,112$ & - & 0,71 \\
\hline & $M_{R}=\mathrm{k}_{1} \cdot \sigma_{d}^{k_{2}}$ & 575 & $-0,108$ & - & 0,67 & 715 & $-0,114$ & - & 0,94 \\
\hline & $M_{R}=\mathrm{k}_{1} \cdot \sigma_{3}^{k_{2}} \cdot \sigma_{d}^{k_{3}}$ & 304 & 0,214 & $-0,153$ & 0,97 & 683 & 0,038 & $-0,137$ & 0,96 \\
\hline & $M_{R}=\mathrm{k}_{1}\left(p_{a}\right) \cdot\left(\frac{\theta}{p_{a}}\right)^{k_{2}} \cdot\left(\frac{\tau_{o c t}}{p_{a}}+1\right)^{k_{3}}$ & 271 & 0,180 & $-0,168$ & 0,90 & 615 & 0,029 & $-0,134$ & 0,95 \\
\hline \multirow{4}{*}{10} & $M_{R}=\mathrm{k}_{1} \cdot \sigma_{3}^{k_{2}}$ & 1650 & $-0,146$ & - & 0,59 & 1032 & 0,063 & - & 0,81 \\
\hline & $M_{R}=\mathrm{k}_{1} \cdot \sigma_{d}^{k_{2}}$ & 5300 & $-0,362$ & - & 0,95 & 896 & 0,083 & - & 0,82 \\
\hline & $M_{R}=\mathrm{k}_{1} \cdot \sigma_{3}^{k_{2}} \cdot \sigma_{d}^{k_{3}}$ & 5261 & 0,073 & $-0,426$ & 0,97 & 860 & 0,047 & 0,052 & 0,92 \\
\hline & $M_{R}=\mathrm{k}_{1}\left(p_{a}\right) \cdot\left(\frac{\theta}{p_{a}}\right)^{k_{2}} \cdot\left(\frac{\tau_{o c t}}{p_{a}}+1\right)^{k_{3}}$ & 3722 & 0,064 & $-0,422$ & 0,96 & 848 & 0,042 & 0,059 & 0,88 \\
\hline
\end{tabular}

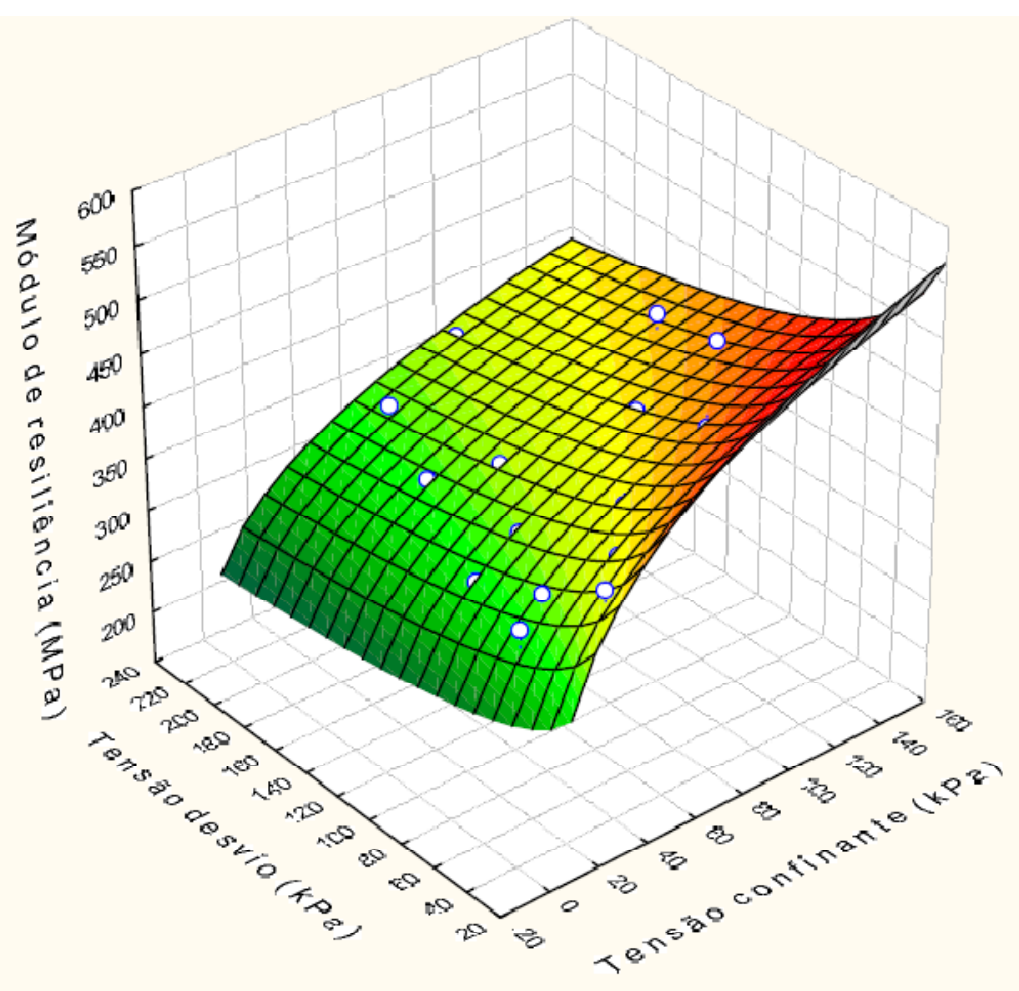

Figura 4.42 - Representação tridimensional do modelo composto para o solo LG' com $5 \%$ de cal 


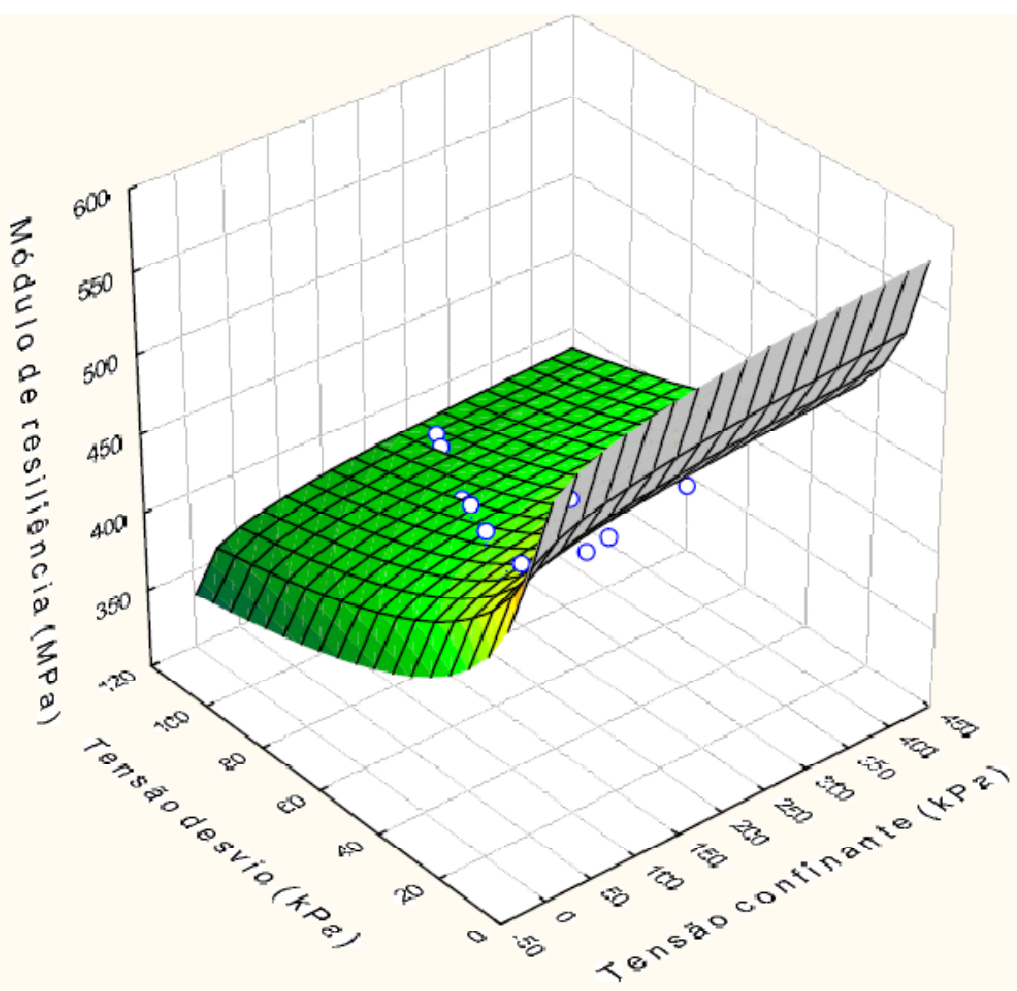

Figura 4.43 - Representação tridimensional do modelo composto para o solo NG' com $5 \%$ de cal

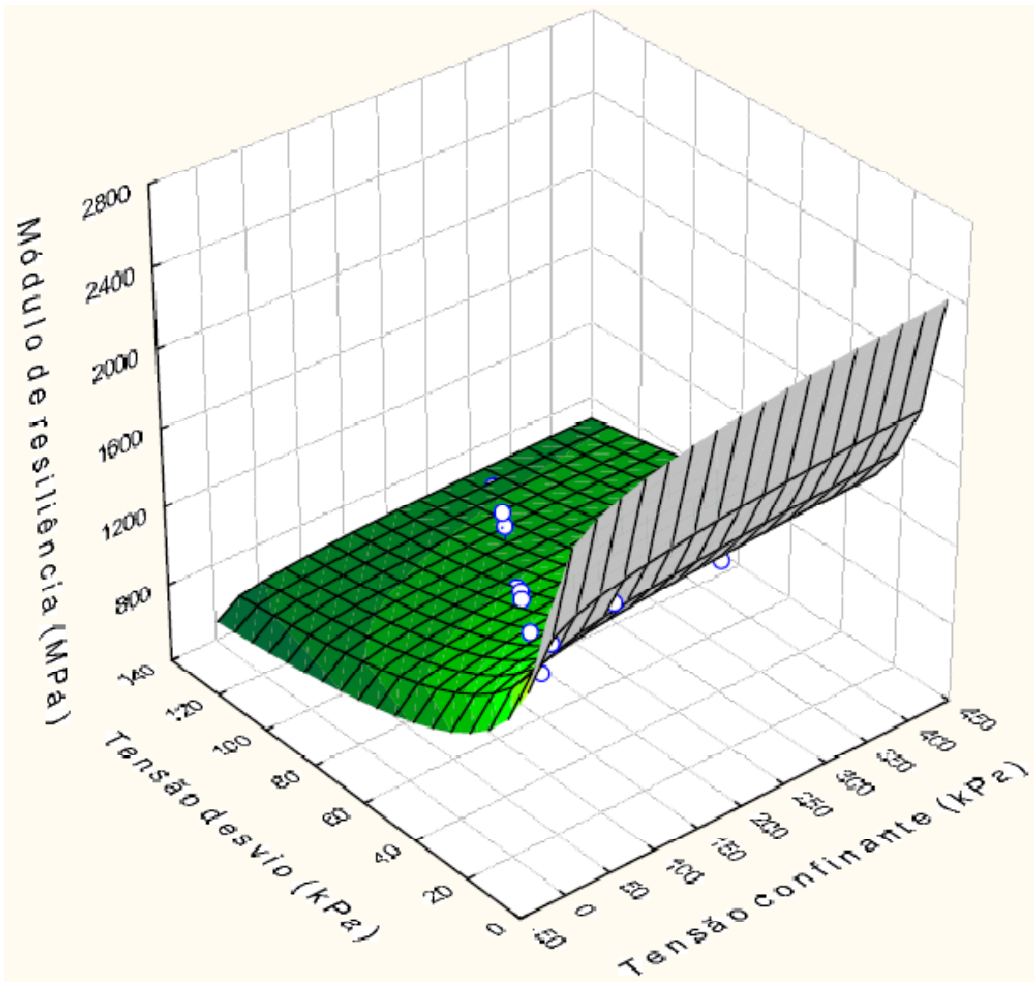

Figura 4.44 - Representação tridimensional do modelo composto para o solo LG' com $10 \%$ de cal 


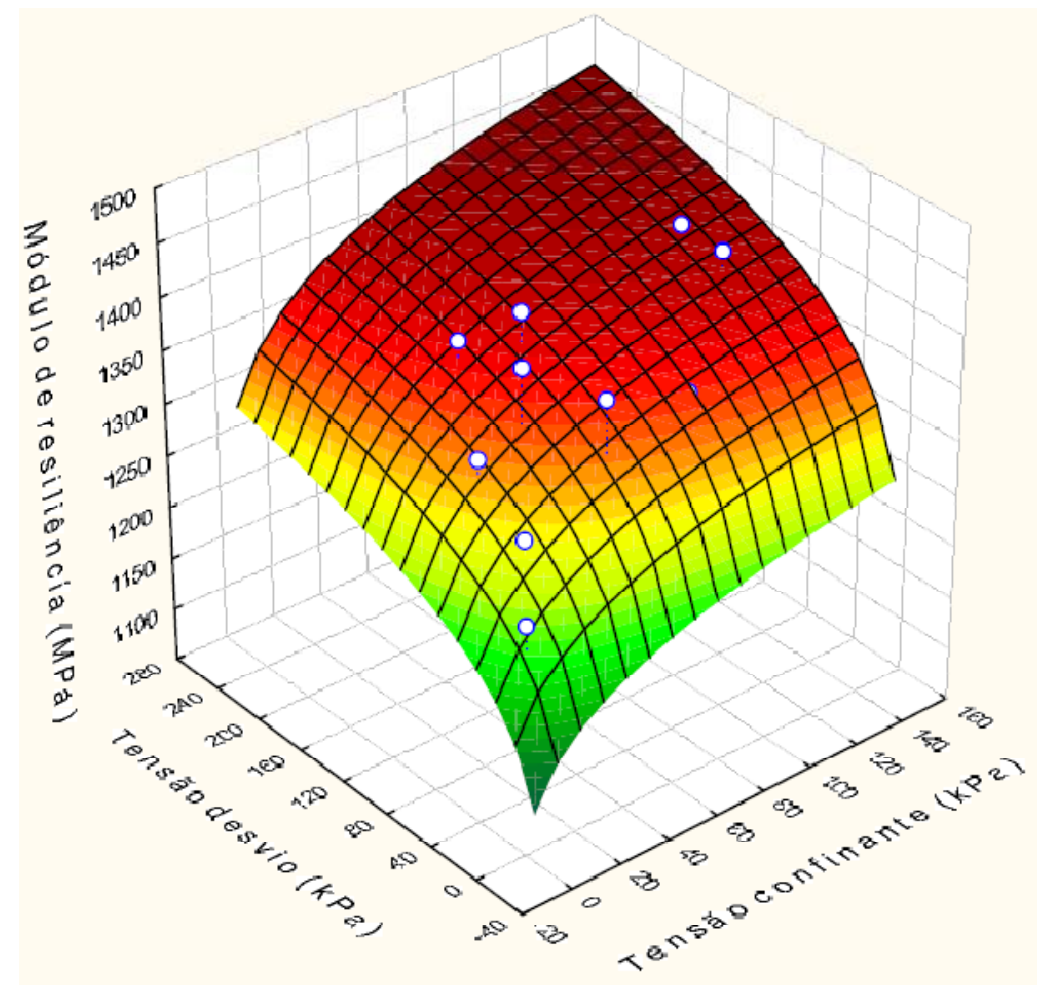

Figura 4.45 - Representação tridimensional do modelo composto para o solo NG' com $10 \%$ de cal

Analisando-se os valores dos coeficientes de regressão $\left(R^{2}\right)$ e tomando-se estes valores como medidas da adaptação dos modelos para representar a variação do módulo de resiliência em função do estado de tensão para ambas as misturas solo-resíduo e teores de cal estudados, observou-se, de maneira geral, que as expressões 4.3 e 4.4 mostram-se as mais satisfatórias para a representação do módulo de resiliência. Entretanto, das duas expressões, a 4.3 apresenta melhor desempenho. Portanto, devido a este fato e a tendência observada no Brasil de se privilegiar esta expressão, as análises seguintes foram efetuadas com base neste modelo.

Analisando-se a Tabela 4.20 e as ilustrações das Figuras 4.42 e 4.43, observa-se para as misturas dos solos LG' e NG' com $5 \%$ de cal, que a influência do resíduo age segundo o mesmo padrão observado anteriormente para misturas solo-cal, ou seja, para ambos os solos, os coeficientes $k_{2}$ e $k_{3}$ são positivos e negativos, respectivamente. Este comportamento da mistura repete o comportamento esperado para materiais geotécnicos, 
onde o aumento das tensões confinante e desvio levam a um aumento e decréscimo, respectivamente, do $M_{R}$, conforme havia sido observado por Parente (2002) para bases estabilizadas com $4 \%$ de cimento. Ainda para estas misturas, comparando-se os valores de $k_{2}$ e $k_{3}$ e considerando-se que as variações das tensões confinantes e desvio são de mesma ordem, pode-se afirmar que a mistura com o solo LG' é influenciada pela variação da tensão confinante e desvio. Para a mistura com o solo NG', observa-se que o valor de $k_{3}$ é 3,6 vezes mais que o valor de $k_{2}$, indicando que a influência da tensão desvio na variação do $M_{R}$ sobrepõe-se à influência da tensão confinante, comportamento típico dos solos finos, destacando-se ainda que o valor de $k_{2}$ muito pequeno indica que a influência de $\sigma_{3}$ é mínima para esta mistura.

Ainda na Tabela 4.20 e as ilustrações das Figuras 4.44 e 4.45, observa-se para as misturas com o solo LG' com $5 \%$ de cal, que o valor do coeficiente $k_{2}$, mantém-se positivo, mas pouco elevado, e que o sinal de $k_{3}$ conserva-se negativo. Isto indica que o valor de $k_{3}$ é 5,8 vezes maior que o valor de $k_{2}$. Este comportamento das misturas solo-resíduo-cal confirma o que seria esperado para misturas cimentadas, onde há pouca influência da tensão confinante e uma influência elevada da tensão desvio. Para as misturas compostas com o solo NG' e $10 \%$ de cal, observa-se que o valor de $k_{2}$ mantém-se positivo, mas pouco elevado, tal como ocorrera para $5 \%$ de cal. Este fato indica que a influência da tensão confinante é positiva, mas pouco expressiva. Para $k_{3}$, ao se aumentar o teor de cal de 5 para $10 \%$, o valor, anteriormente negativo, torna-se positivo, ou seja, o aumento da tensão desvio acarreta o aumento do $M_{R}$. Observa-se ainda que os valores de $k_{2}$ e $k_{3}$ são pequenos e da mesma ordem de grandeza, indicando para esta mistura que o estado de tensão influencia muito pouco o $M_{R}$. Este comportamento é atípico, e não se encontrou na literatura materiais com comportamento semelhante. 


\subsubsection{Avaliação do $M_{R}$ para uma estrutura de pavimento hipotética}

Com o objetivo de se comparar as diversas misturas estudadas, calculou-se, a partir do modelo composto, o módulo de resiliência $\left(M_{R}\right)$ de cada material para o centro da camada de base de uma estrutura de pavimento hipotética. Supôs-se um carregamento composto por duas rodas do eixo padrão, distantes entre si em $30 \mathrm{~cm}$, com raio de carregamento igual a 10,8 cm. A Figura 4.46 ilustra a estrutura considerada, enquanto a Tabela 4.21 apresenta suas principais características.

Figura 4.46 - Estrutura do pavimento hipotético considerada na análise do $M_{R}$

Tabela 4.21 - Características da estrutura do pavimento hipotético

\begin{tabular}{cccc}
\hline Camada & $\begin{array}{c}\text { Espessura } \\
(\mathbf{c m})\end{array}$ & $\begin{array}{c}\text { Coeficiente } \\
\text { de Poisson } \\
(\mathrm{v})\end{array}$ & $\begin{array}{c}\mathbf{M}_{\mathbf{R}} \\
(\mathbf{M P a})\end{array}$ \\
\hline Revestimento & 8,0 & 0,35 & 1500 \\
Base & 25,0 & 0,40 & Variável \\
Sub-base & 15,0 & 0,40 & 100 \\
Subleito & Semi-infinito & 0,45 & 50 \\
\hline
\end{tabular}


Analisou-se os valores do $M_{R}$ através do programa ELSYM 5 por meio de um processo interativo de cálculo. Para a utilização do programa numérico, adotou-se um $M_{R}$ inicial, obtendo-se as tensões principais $\left(\sigma_{z z} ; \sigma_{x x}\right)$ no centro da camada de base da estrutura proposta. Em seguida, foram utilizadas as tensões obtidas pelo programa para "alimentar" o modelo composto adotado, obtendo-se um novo valor para $\circ M_{R}$. Este procedimento novamente foi realizado até que os valores do $M_{R}$ apresentassem erros menores que $1 \%$. Os valores das tensões desvio e confinante foram calculados a partir das equações 4.5 e 4.6, respectivamente. Deve-se esclarecer que $\sigma_{x x}$ é a tensão principal atuante no plano perpendicular à direção em que atua $\sigma_{\mathrm{zz}}$, utilizadas no programa ELSYM 5.

$$
\begin{gathered}
\sigma_{d}=\sigma_{z z}-\sigma_{x x} \\
\sigma_{3}=\sigma_{x x}
\end{gathered}
$$

onde:

$\sigma_{z z}$ : tensão principal vertical $(\mathrm{kPa})$;

$\sigma_{x x}:$ tensão principal horizontal $(\mathrm{kPa})$;

A Tabela 4.22 apresenta os valores do módulo de resiliência calculados através do modelo composto para cada uma das misturas estudadas. Apresentam-se, também, na Tabela 4.22, o modelo e os módulos obtidos por Suarez (2008) para o solo LG', sem adição de cal. As Figuras 4.47 e 4.48 apresentam, respectivamente, os valores do $M_{R}$ em função do teor de cal para as misturas solo-cal e solo-resíduo-cal. 
Tabela 4.22 - Modelo e valores do módulo de resiliência calculados para os modelos das misturas estudadas

\begin{tabular}{|c|c|c|c|c|}
\hline \multirow{2}{*}{ Material } & \multirow{2}{*}{ Modelo } & \multirow{2}{*}{$\begin{array}{c}\mathrm{M}_{\mathrm{R}} \\
(\mathrm{MPa}) \\
\end{array}$} & \multicolumn{2}{|c|}{ Tensões (kPa) } \\
\hline & & & $\sigma_{3}$ & $\sigma_{d}$ \\
\hline Solo LG' puro sem imersão & $M_{R}=422 \sigma_{3}^{0,128} \sigma_{d}^{-0,187}$ & 230 & - & - \\
\hline Solo LG' + $\%$ resíduo + 5\% cal & $\mathrm{M}_{\mathrm{R}}=348 \sigma_{3}{ }^{0,262}{\sigma_{\mathrm{d}}}^{-0,160}$ & 375 & 35,2 & 215,2 \\
\hline Solo LG' + 0\% resíduo + 10\% cal & $M_{R}=52087 \sigma_{3}{ }^{-0,300} \sigma_{d}-0,390$ & 1762 & 60,0 & 253,0 \\
\hline Solo LG' $+40 \%$ resíduo $+5 \%$ cal & $M_{R}=304 \sigma_{3}^{0,214} \sigma_{d}^{-0,153}$ & 263 & 22,4 & 200,4 \\
\hline Solo LG' $+40 \%$ resíduo $+10 \%$ cal & $M_{R}=5261 \sigma_{3}{ }^{0,073} \sigma_{d}{ }^{-0,426}$ & 686 & 51,0 & 234,0 \\
\hline Solo NG' + 0\% resíduo + 5\% cal & $M_{R}=942 \sigma_{3}^{0,053} \sigma_{d}^{-0,225}$ & 339 & 31,6 & 210,6 \\
\hline Solo NG' + 0\% resíduo + $10 \%$ cal & $M_{R}=711 \sigma_{3}{ }^{0,083} \sigma_{d}^{0,207}$ & 3129 & 51,0 & 183,0 \\
\hline Solo NG' $+40 \%$ resíduo $+5 \%$ cal & $M_{R}=683 \sigma_{3}^{0,262} \sigma_{d}{ }^{-0,160}$ & 375 & 31,6 & 179,0 \\
\hline Solo NG' $+40 \%$ resíduo $+10 \%$ cal & $M_{R}=860 \sigma_{3}^{0,262} \sigma_{d}^{-0,160}$ & 1389 & 59,8 & 249,8 \\
\hline
\end{tabular}

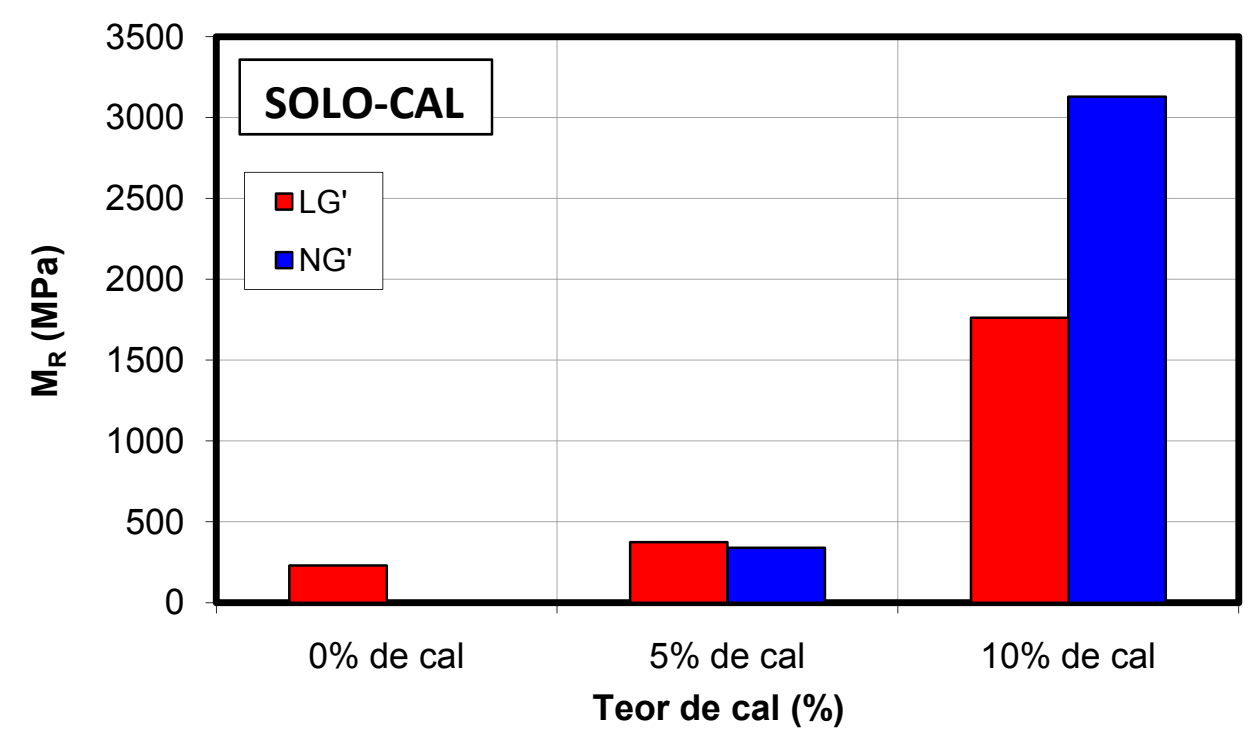

Figura 4.47 - Variação do $M_{R}$ das misturas solo-cal, compostas pelos solos LG' e NG', com o teor de cal

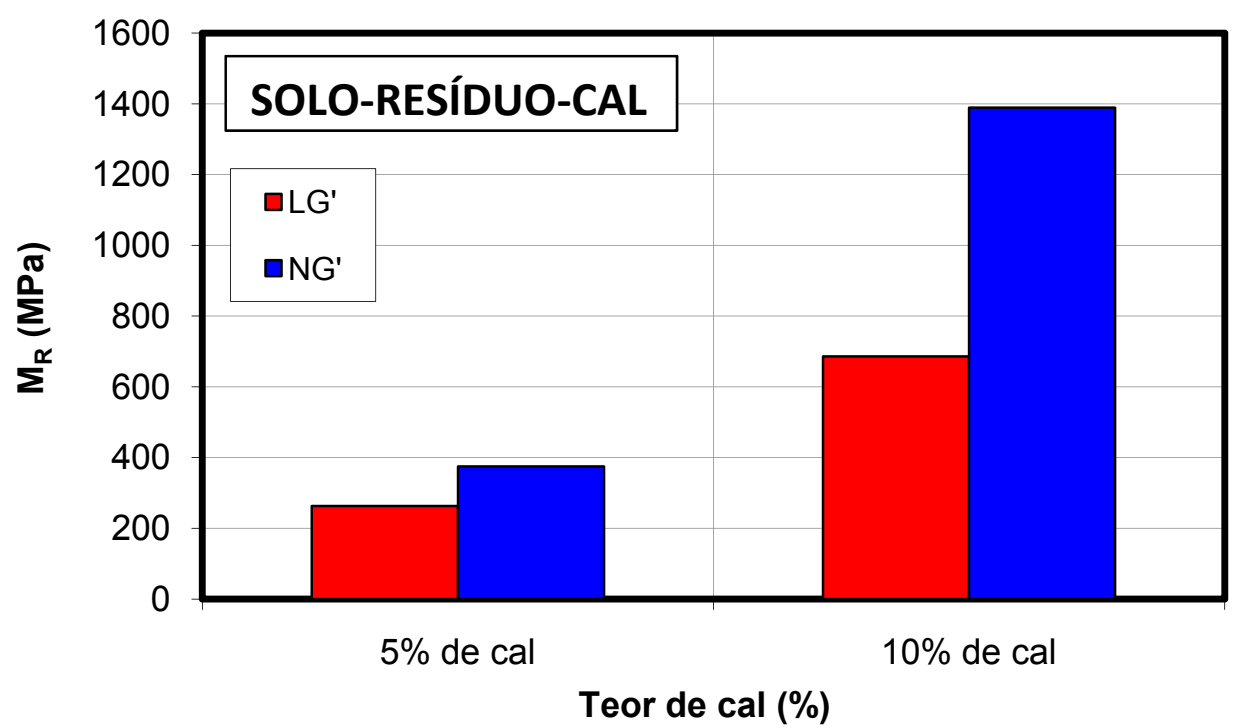

Figura 4.48 - Variação do $M_{R}$ das misturas solo-resíduo-cal, compostas pelos solos LG' e NG', com o teor de cal 
Analisando-se a Figura 4.47, observa-se, para o material argiloso LG' com 5\% de cal, que o módulo de resiliência é $39 \%$ superior ao do solo in natura. Ainda para o teor de $5 \%$ de cal, observa-se que os valores dos $M_{R}$ para ambas as gêneses são praticamente coincidentes. No tocante ao acréscimo de 5 para $10 \%$ de cal, observa-se um elevado ganho no $M_{R}$ de 79 e $89 \%$, respectivamente, para as misturas compostas com os solos LG' e NG'. Destacando-se o crescimento pronunciado para as misturas com o solo NG', onde a mistura composta com este solo e $10 \%$ de cal apresenta um $M_{R} 44 \%$ superior à mistura com o solo LG'.

Analisando-se a Figura 4.48, observa-se, para a mistura com o solo NG' com $5 \%$ de cal, que o $M_{R}$ é $30 \%$ superior a mistura com o solo LG'. No tocante ao acréscimo de 5 para $10 \%$ de cal, observa-se um elevado ganho no $M_{R}$ de 62 e $73 \%$, respectivamente, para as misturas compostas com os solos LG' e NG'. Destacando-se o crescimento pronunciado para as misturas com o solo NG', onde a mistura composta com este solo e $10 \%$ de cal apresenta um $M_{R} 51 \%$ superior à mistura com o solo LG'.

Ao se compararem os módulos das misturas solo-cal e solo-resíduo-cal, observamse para o teor de $5 \%$ de cal, que as misturas solo-cal apresentam $M_{R} 30 \%$ e $10 \%$ superiores as misturas de solo-resíduo-cal, respectivamente para as misturas constituídas com o solo LG' e NG'. Para o teor de $10 \%$ de cal, observa-se que as misturas solo-cal apresentam $M_{R}$ $61 \%$ e $56 \%$ superiores às misturas de solo-resíduo-cal, respectivamente para as misturas constituídas com o solo LG' e NG'. Conclui-se que quanto à gênese, as misturas soloresíduo-cal compostas com o solo NG', para ambos os teores de cal, apresentam $M_{R}$ mais elevados com a adição do resíduo em relação às misturas constituídas com o solo LG'.

Finalmente, conclui-se que tanto as misturas solo-cal quanto às solo-resíduo-cal constituídas com o solo NG' apresentam melhores desempenhos quando comparadas às misturas compostas com o solo LG'. 


\subsection{ENSAIOS AMBIENTAIS}

Conforme já mencionado no Capítulo 3, os ensaios ambientais realizados no solo, resíduo da fabricação de papel e na mistura solo-resíduo-cal são essenciais para se obter parâmetros que permitam acompanhar o desequilíbrio que possa surgir no meio ambiente decorrente da aplicação deste resíduo em camadas de base e sub-base de pavimentos. Os ensaios de lixiviação e solubilização foram realizados conforme a NBR 10005/2004 “Lixiviação de resíduos sólidos" e NBR 10006/2004 "Solubilização de resíduos sólidos", respectivamente. A análise química foi realizada pelo Laboratório de Saneamento da EESC/USP. Na Tabela 4.23 e 4.24 são apresentados os resultados dos ensaios de lixiviação e solubilização, respectivamente. Para efeito de comparação, são também apresentados os limites máximos permitidos de elementos poluentes presentes no extrato, segundo os anexos normativos F e G da NBR 10004/2004, respectivamente, para os ensaios de lixiviação e solubilização.

Tabela 4.23 - Resultados do ensaio de lixiviação do solo NG', resíduo da fabricação de papel e mistura solo-resíduo-cal

\begin{tabular}{ccccccc}
\hline Parâmetro & Unidade & $\begin{array}{c}\text { Limite máximo } \\
\text { no extrato } \\
(\mathrm{mg} / \mathrm{L})\end{array}$ & $\begin{array}{c}\text { Limite de } \\
\text { detecção } \\
(\mathrm{LD})\end{array}$ & $\begin{array}{c}\text { Resíduo da } \\
\text { fabricação } \\
\text { de papel }\end{array}$ & $\begin{array}{c}\text { Solo } \\
\text { NG' }\end{array}$ & $\begin{array}{c}\text { Mistura } \\
\text { solo-resíduo- } \\
\text { cal }\end{array}$ \\
\hline Arsênio & $\mathrm{mg} \mathrm{As} \cdot \mathrm{L}^{-1}$ & 1,0 & 0,0001 & $<\mathrm{LD}$ & $<\mathrm{LD}$ & $<\mathrm{LD}$ \\
Bário & $\mathrm{mg} \mathrm{Ba} \cdot \mathrm{L}^{-1}$ & 70,0 & 0,001 & 21,82 & 6,75 & 31,65 \\
Cádmio & $\mathrm{mg} \mathrm{Cd} \cdot \mathrm{L}^{-1}$ & 0,5 & 0,0006 & 0,028 & $<\mathrm{LD}$ & $<\mathrm{LD}$ \\
Chumbo & $\mathrm{mg} \mathrm{Pb} \cdot \mathrm{L}^{-1}$ & 1,0 & 0,01 & 0,33 & $<\mathrm{LD}$ & 0,35 \\
Cromo Total & $\mathrm{mg} \mathrm{Cr} \cdot \mathrm{L}^{-1}$ & 5,0 & 0,005 & 0,061 & 0,004 & 0,090 \\
Fluoretos & $\mathrm{mg} \mathrm{F} \cdot \mathrm{L}^{-1}$ & 150,0 & 0,01 & 0,43 & 0,28 & 0,27 \\
Mercúrio & $\mathrm{mg} \mathrm{Hg} \cdot \mathrm{L}^{-1}$ & 0,1 & 0,0001 & $<\mathrm{LD}$ & $<\mathrm{LD}$ & $<\mathrm{LD}$ \\
Prata & $\mathrm{mg} \mathrm{Ag} \cdot \mathrm{L}^{-1}$ & 5,0 & 0,001 & 0,031 & 0,004 & 0,030 \\
Selênio & $\mathrm{mg} \mathrm{Se} \cdot \mathrm{L}^{-1}$ & 1,0 & 0,001 & $<\mathrm{LD}$ & $<\mathrm{LD}$ & $<\mathrm{LD}$ \\
$\mathrm{pH}$ do Lixiviado & & $\mathrm{N} \cdot \mathrm{A}$. & 0 & 6,55 & 4,80 & 6,87 \\
\hline
\end{tabular}

Obs. Limite máximo no extrato - anexo normativo (F) - NBR 10004/2004 
Tabela 4.24 - Resultados do ensaio de solubilização do solo NG', resíduo da fabricação de papel e mistura solo-resíduo-cal

\begin{tabular}{ccccccc}
\hline Parâmetro & Unidade & $\begin{array}{c}\text { Limite } \\
\text { máximo } \\
\text { no extrato } \\
(\mathrm{mg} / \mathrm{L})\end{array}$ & $\begin{array}{c}\text { Limite de } \\
\text { detecção } \\
(\mathrm{LD})\end{array}$ & $\begin{array}{c}\text { Solo } \\
\text { NG' }\end{array}$ & $\begin{array}{c}\text { Resíduo da } \\
\text { fabricação } \\
\text { de papel }\end{array}$ & $\begin{array}{c}\text { Mistura } \\
\text { solo- } \\
\text { resíduo- } \\
\text { cal }\end{array}$ \\
\hline Alumínio & $\mathrm{mg} \mathrm{Al} \cdot \mathrm{L}^{-1}$ & $\mathbf{0 , 2}$ & $\mathbf{0 , 0 1}$ & $\mathbf{0 , 1 2}$ & $\mathbf{0 , 1 5}$ & $\mathbf{7 4 , 8 9}$ \\
Cádmio & $\mathrm{mg} \mathrm{Cd} \cdot \mathrm{L}^{-1}$ & 0,005 & 0,0006 & $<\mathrm{LD}$ & $<\mathrm{LD}$ & $<\mathrm{LD}$ \\
Chumbo & $\mathrm{mg} \mathrm{Pb} \cdot \mathrm{L}^{-1}$ & $\mathbf{0 , 0 1}$ & $\mathbf{0 , 0 1}$ & $\mathbf{0 , 0 3}$ & $\mathbf{0 , 2 7}$ & $\mathbf{0 , 1 3}$ \\
Cianetos & $\mathrm{mg} \mathrm{CN} \cdot \mathrm{L}^{-1}$ & 0,07 & 0,001 & $<\mathrm{LD}$ & $<\mathrm{LD}$ & $<\mathrm{LD}$ \\
Cloretos & $\mathrm{mg} \mathrm{Cl} \cdot \mathrm{L}^{-1}$ & 250,0 & 0,01 & 1,8 & 75,0 & 23,0 \\
Cobre & $\mathrm{mg} \mathrm{Cu} \cdot \mathrm{L}^{-1}$ & 2,0 & 0,003 & 0,004 & 0,031 & 0,067 \\
Cromo Total & $\mathrm{mg} \mathrm{Cr} \cdot \mathrm{L}^{-1}$ & $\mathbf{0 , 0 5}$ & $\mathbf{0 , 0 0 5}$ & $\mathbf{0 , 0 1 5}$ & $\mathbf{0 , 1 6 6}$ & $\mathbf{0 , 0 8 6}$ \\
Fenóis Totais & $\mathrm{mg} \mathrm{C} \mathrm{H}_{5} \mathrm{OH}^{-1} \mathrm{~L}^{-1}$ & $\mathbf{0 , 0 1}$ & $\mathbf{0 , 0 0 1}$ & $\mathbf{0 , 0 3 5}$ & $\mathbf{0 , 0 9 2}$ & $\mathbf{0 , 0 5 9}$ \\
Ferro Total & $\mathrm{mg} \mathrm{Fe} \cdot \mathrm{L}^{-1}$ & 0,3 & 0,005 & 0,118 & 0,140 & 0,077 \\
Fluoretos & $\mathrm{mg} \mathrm{F} \cdot \mathrm{L}^{-1}$ & $\mathbf{1 , 5}$ & $\mathbf{0 , 0 1}$ & $\mathbf{0 , 0 6}$ & 3,45 & $\mathbf{6 , 2 5}$ \\
Manganês & $\mathrm{mg} \mathrm{Mn} \cdot \mathrm{L}^{-1}$ & 0,1 & 0,003 & 0,003 & 0,035 & 0,004 \\
Nitratos & $\mathrm{mg} \mathrm{N} \cdot \mathrm{L}^{-1}$ & 10,0 & 0,01 & 0,22 & 8,23 & 1,17 \\
Prata & $\mathrm{mg} \mathrm{Ag} \cdot \mathrm{L}^{-1}$ & 0,05 & 0,001 & $<\mathrm{LD}$ & 0,011 & 0,001 \\
Sódio & $\mathrm{mg} \mathrm{Na} \cdot \mathrm{L}^{-1}$ & $\mathbf{2 0 0 , 0}$ & $\mathbf{0 , 1}$ & $\mathbf{6 , 2}$ & 9744 & 1165 \\
Sulfatos & $\mathrm{mg} \mathrm{SO}{ }_{4}^{2-} \cdot \mathrm{L}^{-1}$ & $\mathbf{2 5 0 , 0}$ & $\mathbf{1}$ & $\mathbf{4}$ & 3900 & $\mathbf{8 5 0}$ \\
Surfactantes & $\mathrm{mg} \mathrm{LAS} \cdot \mathrm{L}^{-1}$ & 0,5 & 0,1 & $<\mathrm{LD}$ & $<\mathrm{LD}$ & $<\mathrm{LD}$ \\
Zinco & $\mathrm{mg} \mathrm{Zn} \cdot \mathrm{L}^{-1}$ & 5,0 & 0,02 & $<\mathrm{LD}$ & 0,014 & 0,052 \\
pH do Solubilizado & & $\mathrm{N} \cdot \mathrm{A}$. & 0 & $\mathbf{9 , 6 8}$ & 10,14 & 12,43 \\
\hline
\end{tabular}

Obs. Limite máximo no extrato - anexo normativo (G) - NBR 10004/2004

Analisando-se a Tabela 4.23, os resultados obtidos no ensaio de lixiviação, observase para os três materiais estudados que as concentrações obtidas estão abaixo dos valores limites máximos previstos no anexo F da norma NBR 10004 (ABNT, 2004a), indicando tratarem-se de materiais não perigosos.

No tocante aos resultados obtidos no ensaio de solubilização, apresentados na Tabela 4.24, observa-se para o solo NG', que os valores encontrados de Chumbo e Fenóis Totais do extrato solubilizado estão, respectivamente, 3 e 3,5 vezes superior aos níveis máximos estabelecidos pela norma. Ao se classificar o solo, observa-se que o mesmo enquadra-se como Classe II-A, isto é, não perigoso e não inerte, conforme NBR 10004. Esse resultado contrasta com o esperado, visto que são materiais geotécnicos. Conforme Klinsky (2008), o solo designado como "Solo Jardim Botânico", também, apresentou características semelhantes, com elevados índices de Fenóis Totais. Outro exemplo foi à pesquisa desenvolvida por Silveira (2006), onde se observaram valores elevados de 
chumbo e sulfatos em misturas solo-cimento com resíduo da construção de demolição. Conclui-se, portanto, que diversos materiais empregados na construção de camadas de pavimentos podem ser considerados como não inertes, inclusive misturas compostas de solo estabilizadas com cal, cimento, etc.

No tocante ao resíduo, observa-se que vários elementos não se enquadram nos limites máximos estabelecidos, são eles: Chumbo, Cromo Totais, Fenóis Totais, Fluoretos, Sódio e Sulfatos. Para as misturas constituídas de solo-resíduo-cal, observa-se que há uma redução das concentrações antes observadas no resíduo, indicando que tais elementos poderiam ter reagido com a cal e o solo, ou mesmo, tenha ocorrido apenas a diluição dos mesmos. A Figura 4.49 ilustra essas variações dos elementos.
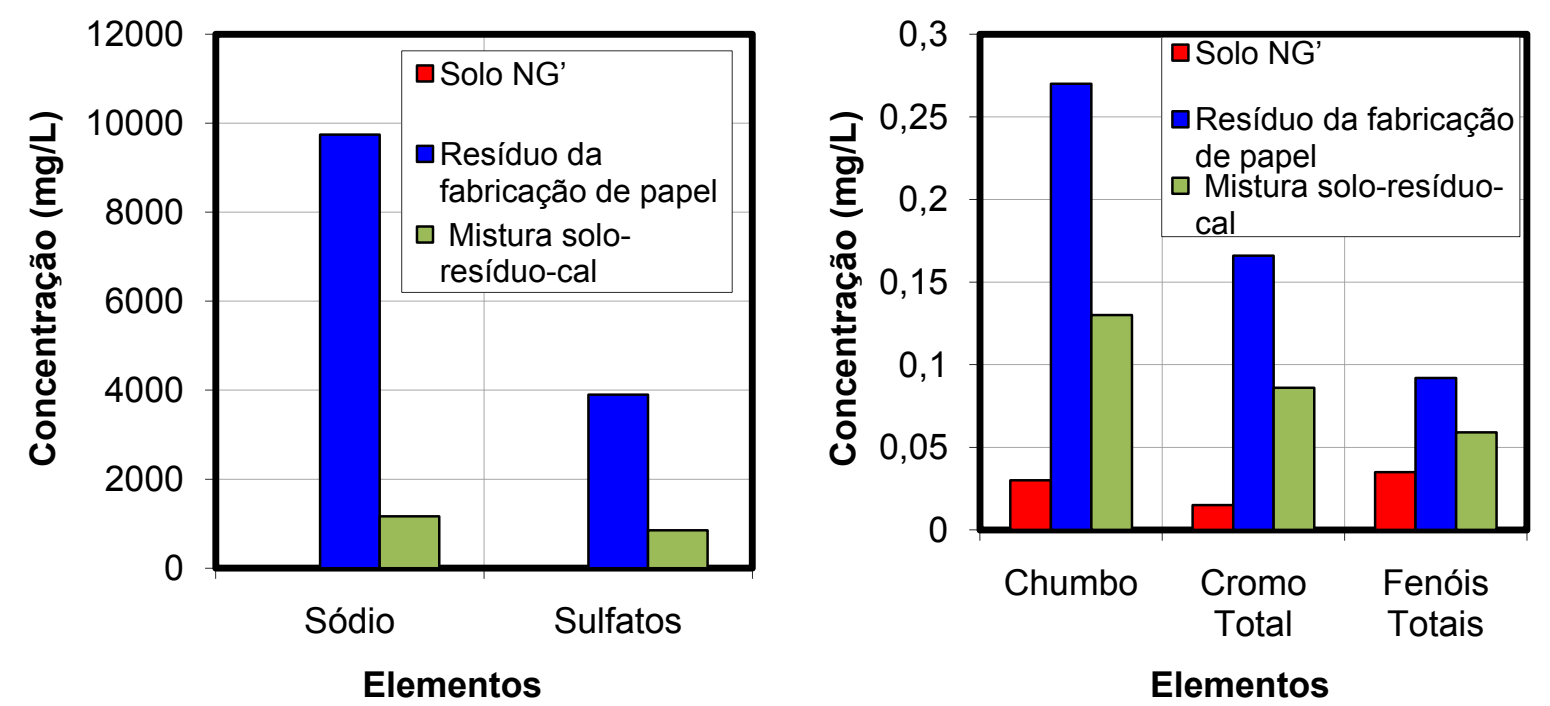

Figura 4.49 - Variação da concentração dos elementos químicos $\mathrm{Na}, \mathrm{SO}_{4}, \mathrm{~Pb}, \mathrm{Cr}$ e $\mathrm{C}_{6} \mathrm{H}_{5} \mathrm{OH}$

Observa-se na Figura 4.49, que o solo apresentava concentrações muito abaixo do limite máximo no extrato de Sódio e os Sulfatos, e a análise realizada para o resíduo apresentou uma elevada concentração destes elementos. Entretanto, para as misturas de solo-resíduo-cal, observa-se uma redução de $88 \%$ e $78 \%$ da concentração, respectivamente do Sódio e dos Sulfatos. Observa-se na Figura 4.49 que já existe uma concentração dos 
elementos no solo estudado, e com exceção do Chumbo, as concentrações dos elementos apresentam-se superiores às máximas exigidas por norma. No tocante à análise do resíduo, observa-se elevados teores destes elementos, entretanto, repete-se o observado anteriormente, onde há uma redução destas concentrações quando comparadas à mistura solo-resíduo-cal, respectivamente, de $52 \%, 48 \%$ e $36 \%$ para os parâmetros Chumbo, Cromo Total e Fenóis Totais. A Figura 4.50 ilustra as concentrações para o Alumínio e os Fluoretos.

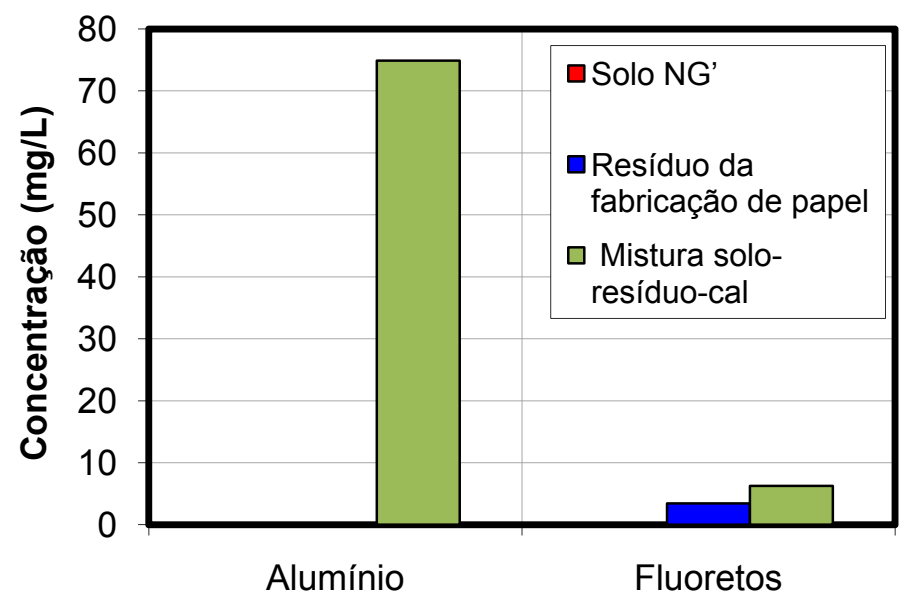

Elementos

Figura 4.50 - Variação da concentração dos elementos químicos Al e F-

Para os elementos apresentados na Figura 4.50, observa-se que a reação do solo entre o resíduo e a cal, desencadeou o aumento desses parâmetros, identificando concentrações superiores às do solo e resíduo. Destaca-se a elevada concentração de Alumínio não identificado no solo e nem no resíduo.

Segundo Nóbrega (2005), ressalta-se que nos pavimentos, a situação real é mais próxima das condições em que são realizados os ensaios de lixiviação do que os ensaios de solubilização, pois não é comum no Brasil os pavimentos ficarem imersos totalmente em água durante 7 dias (procedimento do ensaio conforme NBR 10006). Com base no exposto acima, mesmo quando as classificações ambientais indicarem que os materiais não são 
inertes, estes não devem ser inviabilizados para o emprego em pavimentação, e sim deve haver a necessidade de uma aplicação e monitoramento dos parâmetros ambientais, bem como acompanhar o desequilíbrio que possa surgir no meio decorrente de aplicações de resíduos. 


\section{CONCLUSÕES}

\subsection{CONSIDERAÇÕES INICIAIS}

Esta pesquisa teve como objetivo analisar as propriedades físicas e o comportamento mecânico, através da avaliação dos resultados de ensaios laboratoriais, de misturas constituídas por três tipos diferentes de solo e resíduo da fabricação de papel (lama de calcário e dregs), estabilizadas com cal, visando sua utilização em camadas de bases e sub-bases de pavimentos. A título de comparação, também foi avaliado o comportamento mecânico de misturas solo-cal, compostas por dois tipos diferentes de solos quanto ao comportamento laterítico e não-laterítico.

É importante ressaltar que todas as conclusões apresentadas neste capítulo restringem-se ao universo dos materiais e das condições pesquisadas.

\subsection{PRINCIPAIS CONCLUSÕES QUANTO A COMPACTAÇÃO DAS MISTURAS}

Analisando-se os parâmetros de compactação, constatou-se que, para as misturas não estabilizadas, a adição do resíduo produziu uma redução da massa específica seca máxima e um aumento da umidade ótima. Sendo que os dois solos argilosos apresentam um comportamento muito semelhante quando se analisa as variações da massa específica 
seca máxima e umidade ótima. Estas variações se devem ao aumento do teor de finos, resultado do acréscimo de resíduo. Por outro lado, a adição ou aumento do teor de cal também age no mesmo sentido, diminuindo a $\rho_{\mathrm{dmax}}$ e aumentado a $\omega_{0}$. No tocante ao solo arenoso, observa-se o mesmo sentido supracitado ao se adicionar o resíduo ou quando se eleva o teor de cal nas misturas de solo-resíduo-cal. Pode-se concluir que para os solos argilosos o comportamento laterítico influencia pouco na variação da $\rho_{\mathrm{dmax}}$ e da $\omega_{0}$. Para o solo arenoso laterítico observa-se que o comportamento diferenciado evidencia que a granulometria é o fator preponderante na variação da umidade ótima e da massa específica seca máxima, se comparado com a influência da gênese do material.

\subsection{DESEMPENHO DAS MISTURAS SOLO-RESÍDUO, SOLO- CAL E SOLO-RESÍDUO-CAL AOS 7 DIAS DE CURA}

Observou-se que as resistências à compressão simples e diametral e o módulo tangente inicial aos 7 dias de cura para ambos os solos sem adição de resíduo apresentam ganhos crescentes quando se aumenta o teor de cal. Sendo para o teor de $5 \%$ de cal favoráveis ao solo LG', quando o teor passa para $10 \%$ de cal há uma inversão e o solo NG' apresenta resistências e rigidezes superiores. De maneira geral, sabe-se que os materiais mais finos são mais afeitos à ação da cal, da mesma maneira que os solos não-lateríticos. Assim, para o teor de $5 \%$, supõe-se que o efeito da granulometria seja maior que a da gênese, tendo em vista que a granulometria do solo LG' ser "mais fina" em comparação à do solo NG'. Para o teor de $10 \%$ de cal, indica que maiores teores do aditivo, a influência da gênese passa a ser predominante frente à influência da granulometria, tendo em vista a resistência do solo NG' ser superior a do solo LG'. Finalmente, destaca-se o crescimento pronunciado da resistência do solo NG' quando se aumenta o teor de cal de $5 \%$ para $10 \%$ ao se comparar ao comportamento do solo LG' nas mesmas condições. 
No tocante às misturas com $40 \%$ de resíduo, observa-se que o acréscimo de cal conduz ao aumento da resistência para ambos os solos argilosos, fato que não ocorre para o solo LA'. Constatando que a cal reage principalmente com a fração fina dos materiais. Observam-se, também, valores próximos de resistência entre os solos argilosos, constatando que a gênese não tem grande influência na mistura solo-resíduo-cal. Para o solo LA' ao se elevar o teor de $5 \%$ para $10 \%$ de cal, observa-se que houve um acréscimo de $21 \%$ da RCD, este fato não ocorreu na RCS, evidenciando que a ação da cal atua de maneira mais eficaz na resistência a tração do que a compressão, justificando o que já era esperado para solos arenosos. No tocante ao $E_{0}$, observa-se que a rigidez do solo NG' é superior a mistura com solo LG', para o teor de $5 \%$ de cal, e é inferior a mistura como o solo LG', para o teor de $10 \%$ de cal. Caracterizando que para este último teor a mistura de soloresíduo-cal composta pelo solo LG' apresenta melhor desempenho em relação à composta pelo solo NG'. Finalmente, destaca-se o crescimento pronunciado do $E_{0}$ do solo LG' quando se aumenta o teor de cal de $5 \%$ para $10 \%$ ao se comparar ao comportamento do solo NG' nas mesmas condições.

Verificou-se que a adição do resíduo agiu como um redutor da resistência. Entretanto, todas as misturas de solo-resíduo estabilizadas com cal, adquiriram resistências superiores quando comparadas às mesmas não estabilizadas. Apesar da redução das resistências obtidas das misturas de solo-resíduo-cal, as mesmas são promissoras para a utilização em camadas de base, quando adicionados $10 \%$ de cal, e para camadas de subbase, quando adicionados $5 \%$ de cal. Segundo dados apresentados na State of the art 5 Lime stabilization (TRB, 1987), pode-se considerar que tanto as misturas solo-cal como as misturas solo-resíduo-cal, com $10 \%$ de cal, são misturas reativas a ação da cal, visto que apresentou um incremento de resistência superior a $345 \mathrm{kPa}$ quando comparados com os solos naturais. 
O módulo de resiliência das misturas solo-cal e solo-resíduo-cal é influenciado pelas variáveis: tensão aplicada, gênese do solo argiloso e teor de cal. Constatou-se que as misturas solo-resíduo-cal com $5 \%$ de cal, apesar de apresentarem uma redução do $M_{R}$, mantiveram-se com o mesmo comportamento quando comparadas às misturas solo-cal. Verificou-se que as misturas com o teor de $10 \%$ de cal, apresentaram comportamentos atípicos, conforme apresentado e discutidos no Capítulo 4.

Em todas as situações, as misturas de solo-cal apresentaram rigidezes maiores que as apresentadas pelas misturas solo-resíduo-cal. Conclui-se também que as misturas compostas com solo de comportamento não-laterítico apresentaram valores do $M_{R}$ maiores que as misturas compostas com solo de comportamento não laterítico.

\subsection{INFLUÊNCIA DO TEMPO DE CURA NAS MISTURAS SOLO- CAL E SOLO-RESÍDUO-CAL COM 10\% DE CAL}

Constatou-se que o aumento no tempo de cura produz um aumento continuo nas resistências à compressão simples e diametral e no módulo tangente inicial para as misturas solo-cal e solo-resíduo-cal, constituídas por ambas as gêneses do solo argiloso. Supõe-se que este comportamento seja decorrente da reação pozolânica da cal com o solo e com o resíduo a qual se desenvolve ao longo do tempo. Por outro lado, verificou-se uma susceptibilidade a ação da cal maior na mistura constituída com o solo NG', na qual comparando com as misturas constituídas com o solo LG', apresentou acréscimos de RCS, RCD e $E_{0}$, respectivamente de 57,48 e $41 \%$ aos 84 dias de cura para misturas solo-cal, e respectivamente de 39,46 e $55 \%$ aos 84 dias de cura para misturas solo-resíduo-cal. Observa-se, também, que as porcentagens de queda da RCD são inferiores quando comparadas às das RCS, indicando que à ação da cal é mais eficiente quanto à resistência à tração do que a compressão. 
Finalmente, conclui-se que a ação do resíduo agiu como um redutor da resistência e rigidez. Entretanto, as misturas de solo-cal, constituídas com 10\% de cal, enquadram-se, como material para base e sub-base de pavimentos, de acordo com as resistências às compressões simples mínimas estabelecidas segundo o procedimento desenvolvido em Illinois apresentados na State of the art 5 - Lime stabilization (TRB, 1987), na qual estabelece que para corpos-de-prova ensaiados com 28 dias de cura, a uma temperatura de $22^{\circ} \mathrm{C}$, os mesmos obtenham resistências mínima de $700 \mathrm{kPa}$ e $1000 \mathrm{kPa}$, respectivamente para camadas de sub-base e base. Para as misturas de solo-resíduo-cal, seguindo o mesmo padrão de análise feita para as misturas de solo-cal, o solo NG' enquadra-se, quanto à RCS mínima, como material para base e sub-base de pavimentos, entretanto o solo LG' obteve resistência apenas para sua utilização como material para sub-base de pavimento.

\subsection{INFLUÊNCIA DA IMERSÃO EM ÁGUA NAS MISTURAS SOLO-CAL E SOLO-RESÍDUO-CAL}

Verificou-se que independentemente do solo utilizado, a imersão em água provocou reduções das resistências e rigidez das misturas solo-cal e solo-resíduo-cal. Observaramse, também, resistências e rigidez crescentes com o aumento do teor de cal e o aumento do tempo de cura para corpos-de-prova ensaiados com imersão, repetindo o comportamento dos ensaiados sem imersão e que de maneira geral, manteve-se uma perda de resistência e rigidez constantes com a variação do tempo de cura e teor de cal, em relação aos corposde-prova ensaiados sem imersão. Destacam-se os fatos das misturas estabilizadas com cal ficarem estáveis, não se desintegrando e que no $E_{0}$ ter sido observado perdas de rigidez reduzidas quanto à ação da água, podendo em algumas misturas essas perdas poder ser consideradas de mesma ordem de grandeza da dispersão dos resultados do ensaio. Conclui-se, portanto, que o aumento da quantidade de estabilizante contribui para a redução da suscetibilidade das misturas à ação da água. 


\subsection{PRINCIPAIS CONCLUSÕES QUANTO AOS ENSAIOS AMBIENTAIS}

Em relação os ensaios ambientais realizados no solo, resíduo da fabricação de papel e na mistura solo-resíduo-cal, os materiais classificam-se como pertencentes à Classe II-A, isto é, materiais não perigosos e não inerte, conforme a norma NBR 10004 (ABNT, 2004,a). Entretanto, pressupõe-se que este fato não seja um fator restritivo para a utilização da mistura em camadas base e sub-base de pavimentos, visto que alguns solos tropicais e o próprio solo analisado, sem contaminação aparente, quando classificado apresentam-se como materiais não inertes. Conclui-se, portanto, que diversos materiais empregados na construção de camadas de pavimentos podem ser considerados como não inertes, inclusive misturas compostas de solo estabilizadas com cal, cimento, etc.

Verificou-se que no resíduo vários elementos não se enquadram nos limites máximos estabelecidos, são eles: Chumbo, Cromo Totais, Fenóis Totais, Fluoretos, Sódio e Sulfatos. Entretanto, análises feitas no solo, acusaram baixas concentrações destes elementos. Para as misturas constituídas de solo-resíduo-cal, observa-se que há uma redução das concentrações antes observadas no resíduo, pressupondo que tais elementos reagiram com a cal e/ou o solo, ou mesmo, tenha ocorrido apenas a diluição dos mesmos. Destaca-se a elevada concentração de alumínio não identificado no solo e nem no resíduo apresentada nas misturas constituídas de solo-resíduo-cal, fenômeno desconhecido em diversas biografias estudadas. Conclui-se, portanto, que são essenciais obter parâmetros que permitam acompanhar o desequilíbrio que possa surgir no meio ambiente decorrente da aplicação deste resíduo em camadas de base e sub-base de pavimentos. 


\subsection{CONSIDERAÇÕES FINAIS E RECOMENDAÇÕES PARA TRABALHOS FUTUROS}

$\mathrm{Na}$ análise de variância feita para as resistências à compressão simples, tração indireta, módulo tangente inicial e módulo de resiliência verificou-se que a influência do tipo de solo, teor de cal, teor de resíduo, tempo de cura e influência de imersão é significante para um nível de confiança de 95\%. Destacando-se sob os resultados do módulo tangente e de resiliência que o estudo apresentou, para algumas misturas e condições, pouca influência entre as variáveis supracitadas. Porém, considerando as análises realizadas nos itens 4.3.2. e 4.3.4, para $E_{0}$ e $M_{R}$ respectivamente, a incongruência em pauta dar-se-ia em razão das somas dos efeitos serem de magnitudes parecidas, ou seja, que a presença da interação dos fatores encobriria o efeito da variável considerada.

Finalmente, conclui-se que o reaproveitamento do resíduo da fabricação de papel é promissor como material de construção de estruturas de pavimento e que o mesmo favoreceria o meio ambiente por se evitar a disposição inadequada deste resíduo em aterros sanitários.

Para que se possa ampliar os conhecimentos em relação ao comportamento das misturas de solo-resíduo-cal e assim facilitar sua aceitação como material para base e subbase de pavimentos rodoviários, sugere-se para trabalhos futuros:

- Pesquisar os resíduos no comportamento das misturas com solos argilosos para teores de resíduo não estudados, buscando teores de ótimos de resíduo;

- Construir e monitorar de um trecho experimental, sob condições conhecidas, para que se investigue o comportamento mecânico do resíduo incorporado a solos argilosos, assim como o impacto ambiental que o resíduo poderia causar ao longo do tempo; 
- Realizar avaliações econômicas e ambientais sobre o emprego de resíduo da fabricação de papel na construção de camadas de pavimentos visando as vantagens e desvantagem da aplicação deste resíduo;

- Analisar o efeito do tempo de cura, teor de cal e a influência da ação da água no módulo de resiliência; 


\section{REFERÊNCIAS BIBLIOGRÁFICAS}

_. AASHTO M145: Classification of Soils and Soil-Aggregate Mixtures for Highway Construction Purposes. Washington, 1991.

AASHTO T 307-99: Standard method of test for determining the resilient modulus of soils and aggregate materials, 1999.

.NBR 10004: Resíduos sólidos. Classificação. Fórum Nacional de Normalização. Rio de Janeiro, 2004.

NBR 10005: Lixiviação de resíduos sólidos. Rio de Janeiro, 2004.

NBR 10006: Solubilização de resíduos sólidos. Rio de Janeiro, 2004.

NBR 6508: Grãos de solo que passam na peneira 4,8mm - determinação da massa específica. Rio de Janeiro, 1984.

NBR 7175: Cal hidratada para argamassas. Rio de Janeiro, 2003.

NBR 7180: Solo - Determinação do limite de plasticidade. Rio de Janeiro, 1984.

NBR 7181: Solo - Análise granulométrica. Rio de Janeiro, 1984.

NBR 7182: Solo - Ensaio de Compactação. Rio de Janeiro, 1984.

AHLBERG, H. L.; BARENBERG, E. J. Pozzolanic Pavements. Engineering Experiment Station. University of Illinois. Bulletin $n^{\circ} 473$, p.165, 1965.

ALBERTO C. O. FILHO; FERNADEZ, F. M.; LIMA, N. R.; DUTRA, N.; RAMOS, W. Resíduos sólidos gerados diretamente dos processos industriais. In: Congresso Anual da Celulose e Papel. 30 , São Paulo, 1997.

AMERICAN ASSOCIATION OF STATE HIGHWAY AND TRANSPORTATION OFFICIALS. AASHTO Designation TP46-94: Standart test method for determining the resilient modulus of soils and aggregate materials. Washington, DC. 1996.

AMERICAN SOCIETY FOR TESTING MATERIALS. ASTM D2487: Standard Practice for Classification of Soils for Engineering Purposes (Unified Soil Classification System). West Conshohocken, 2006. 
ASSOCIAÇÃO BRASILEIRA DE NORMAS TÉCNICAS. NBR 6459: Solo - Determinação do limite de liquidez. Rio de Janeiro, 1984.

BASMA, A. A.; TUNCER, E. R. Effect of lime on volume change and compressibility of expansive clays. Transportation Research Record1295:52-61. 1991

BELlOTE, A. F. J.; SILVA, H. D.; FERREIRA, C. A.; ANDRADE, G. C. Resíduos da indústria de celulose em plantios florestais. Boletim de Pesquisa Florestal, Colombo, n 37, p. 99-106, Jul/dez. 1998, 2003.

BHUIYAN, J. U.; DALLAS, N. L.; GRAVES, R. E. Evaluation of calcareous base course materials stabilized with low percentage of lime in South Texas. In: Transportation Research Board, $\mathrm{n}^{\circ}$ 1486, p. 77-87, 1995.

BIERMANN, C. J. Essentials of pulping and papermaking. San Diego: Academic Press. Inc., 1993.

BRACELPA, ASSOCIAÇÃO BRASILEIRA DE CELULOSE E PAPEL. Desempenho do setor em 2007. Disponível em: http://www.bracelpa.org.br/br/index.htm. Acesso em: outubro 2008. 2007.

CANADIAN ENVIRONMENTAL PROTECTION. Act Priority Substances List Assessment, Report $N^{\circ}$.2. Effluents from Pulp Mills Using Bleaching. Health and Welfare. Ontario, Canadá. Disponível em: http://www.hc-sc.gc.ca. Acesso em: agosto 2008. 1991.

CASTRO, E.; LUÍS, A. S. O solo-cal na pavimentação de estradas e aeródromos. In: Revista da Sociedade Portuguesa de Geotecnia. №10, 1974.

COHN, P. E.; RIBEIRO, R. N. Medição "on line" do alkali total nos licores branco e verde empregando tecnologia FT-NIR. $35^{\circ}$ Congresso e Exposição Annual de Celulose e Papel. ABTCP - Associação Brasileira Técnica de Celulose e Papel. Outubro, São Paulo, S. P., 2002.

CPRH, COMPANHIA PERNANBUCANA DE MEIO AMBIENTE. Roteiro complementar de licenciamento e fiscalização: Indústria de papel e celulose. Recife, 95p., 1998.

DEPARTAMENTO NACIONAL DE ESTRADAS DE RODAGEM. CLA 259-96: Classificações de solos tropicais para finalidades rodoviárias utilizando corpos-de-prova compactados em equipamento miniatura. Rio de Janeiro, 1996.

DUNCAN, J.M.; CHANG, C. Y. Nonlinear analysis of stress and strain in soils. Journal of the Soil Mechanics and Foundations Division, v.96, n.5, p.1629-53, 1970.

EL-RAWI, N. M.; AWAD, A. A. Permeability of lime stabilized soils. In: Transportation Engineering Journal, ASCE, vol 107, nTE1, p.25-35, 1981.

EPA, U. S. ENVIRONMENTAL PROTECTION AGENCY. Profile of the pulp and paper industry $2^{\text {nd }}$ Edition. Office of Compliance Sector Notebook Project. Novembro. Washington, 2002.

FONSECA, J. A. V. M.; BARBOSA, M.; PINTO, N. O.; SALAN, R. S.; SOBRINHO, G. D.; BRITO, N. N.; CONEGLIAN, C. M. R.; TONSO, S.; PELEGRINI, R. Tratamento de efluentes líquidos de indústria de papel e celulose. III Fórum de Estudos Contábeis. Faculdades Integradas Claretianas. Rio Claro 2003 
GARCIA-DIAZ, A.; PHILLIPS, D. T. Principles of experimental desing and analysis. Chapman \& Hall. Londres, 1995.

GRAVES, R. E. Strength developed from carbonate cementation in silica/carbonate system as influenced by cement-particle mineralogy. M. S thesis. University of Florida, 1987.

GRUBBS, F. E. Procedures for detecting outlying observations in samples. Technometrics, v.11, $\mathrm{n}^{\circ} .1, \mathrm{p} .1-21,1969$.

GUIMARÃES, J. E. P. Estabilização de solos, nova e importante aplicação da cal seus conceitos e suas vantagens. ABPC - Associação Brasileira dos produtores de cal, 1971.

HERRIN, M.; MITCHELL, H. Lime-soil mixtures. Highway Research Board Bulletin, n. 304, p. 99-138. Washington, D.C., 1961.

KLINSKY, L. M. G. Proposta de reaproveitamento de areia de fundição em sub-bases e bases de pavimentos flexíveis, através de sua incorporação a solos argilosos. 189p. Dissertação (Mestrado) - Escola de Engenharia de São Carlos, Universidade de São Paulo, 2008.

LATHINEN, P. Fly ash mixtures as flexible structural materials for low-volume roads. FINNRA reports 70/2001. Helsinque, Finlândia. Disponível em: http://lib.tkk.fi/Diss/2001/isbn9512257076/isbn9512257076.pdf . Acesso em: abril 2008. 2001.

LIMA, D. C. Algumas considerações relativas a aspectos da estabilização dos solos, em particular à estabilização solo-cal. Dissertação (mestrado). Escola de Engenharia de São Carlos. Universidade de São Paulo. São Carlos, SP, 1981.

LOVATO, R. S. Estudo do comportamento mecânico de um solo laterítico estabilizado com cal, aplicado à pavimentação. 144p. Dissertação (Mestrado em Engenharia) Universidade Federal do Rio Grande do Sul, Porto Alegre. 2004.

MACHADO, C. C.; PEREIRA, R. S.; LIMA, D. C.; PORTUGAL, C. R. M.; PIRES, J. M. M.; VIEIRA, G. S. Industrial solid waste (whitewash mud) use in forest road pavements. Sociedade de Investigações Florestais. Revista Árvore, Viçosa, MG, v.28, n.4, p.547-551, 2004.

MEIO AMBIENTE, PREOCUPAÇÃO DAS PESQUISAS COM PAPEL. Acervo de artigos da Universidade Estadual de Campinas, UNICAMP. Disponível no site: http://www.unicamp.br/unicamp/divulgacao/2004/01/28/meio-ambiente-preocupacaodas-pesquisas-com-papel. Acesso em: outubro 2008. 2004.

MENDONÇA, A. A.; LIMA, D. C.; BUENO, B. S.; FONTES, M. P. F.; COUTO, L. G. Misturas solo-cal: Efeito da cal, tempo de cura e imersão na resistência. Revista da Sociedade Portuguesa de Geotecnia, n.91, 2001.

MOLINA, C. E. C. Estudo do comportamento mecânico de misturas de resíduo da fabricação de papel e solo para a utilização na construção rodoviária. Dissertação (mestrado), Escola de Engenharia de São Carlos, Universidade de São Paulo, São Carlos, 2004. 
MUNIZ, A. L.; ANDRADE, J. F. M. Potencial técnico de geração do setor de papel e celulose no Brasil: presente e futuro. XV SNPTEE - Seminário Nacional de Produção e Transmissão de Energia Elétrica. Foz do Iguaçu, Paraná, Outubro, 1999.

NCASI, NATIONAL COUNCIL FOR AIR AND STREAM IMPROVEMENT. Benefical use of industrial by-products. Identification and review of material specifications, performance standards, and technical guidance. Dezembro, 2003.

NÓBREGA, L. M.; ROSA, N. M. G. S.; CAMPOS, L. E. P.; SOARES, J. B. Avaliação ambiental de escória de ferroliga aplicada em revestimentos de pavimentos em Salvador. In: Reunião Anual de Pavimentação. Curitiba. 36ª RAPv. 2005.

NOGAMI, J. S.; VILLIBOR, D. F. Pavimentação de baixo custo com solos lateríticos. Editora Vilibor. São Paulo, p. 240, 1995.

NOLASCO, M. A. Redução da produção de lodo no tratamento aeróbico de efluentes da indústria de celulose e papel. Tese (doutorado), Escola de Engenharia de São Carlos, Universidade de São Paulo, São Carlos, 1998.

PAPER INDUSTRY INTERNATIONAL HALL FAME. Glossary of papermaking terms. Disponível em: http://www.paperhall.org/info/glossary.html. Acesso em: abril 2008. 1993.

PARENTE, E. B. Avaliação do comportamento mecânico de solo-cimento e fosfogesso e cimento para uso na construção rodoviária. 130p. Dissertação (Mestrado) Escola de Engenharia de São Carlos, Universidade de São Paulo. São Carlos, 2002.

PARREIRA, A. B.; CARMO, C. A. T.; CUNHO, F. J. C. Estudo do módulo de resiliência de materiais usados em pavimentação. In: Reunião Anual de Pavimentação, 3. Anais. São Paulo. ABPV v.1, p.233-247. 1998.

PIOTTO, Z. C. Eco-eficiência na indústria de celulose e papel - estudo de caso. Tese (doutorado). Escola Politécnica da universidade de São Paulo. Departamento de Engenharia Hidráulica e Sanitária. São Paulo, 2003.

SANTOS, C. P.; REIS, I. N.; MOREIRA, J. E. B.; BRASILEIRO, L. B. Papel: como se fabrica? Química e Sociedade. Revista Química nova na Escola, n.14, novembro 2001.

SILVEIRA, P. E. M.; NÓBREGA, C. A. Aplicação do resíduo de construção e demolição em solo - cimento. HOLOS Environment, v.5 n.2, Centro de Estudos Ambientais Rio Claro - São Paulo. 2006.

SUAREZ D. A. A. Estudo do comportamento mecânico de dois solos lateríticos do Estado de São Paulo com adição de emulsão asfáltica. 144p. Dissertação de Mestrado. Escola de Engenharia de São Carlos - Universidade de São Paulo. São Carlos 2008.

THOMPSON, M. R. Mixture desing for lime-treated soils. Civil Engineering Series, Highway Engineering Series, $n^{\circ} 26$. University of Illinois, 24p., 1969.

TRANSPORTATION RESEARCH BOARD, NATIONAL RESEARCH COUNCIL. State of the art 5 - Lime Stabilization Reactions, Properties, design, and Construction. Washington, D.C., 1987. 
U.S. ARMY CORPS OF ENGINEERS. Department of the army. Engineering and Design. Use of waste materials in pavement construction. Washington, DC., 1999.

ZHOU, H.; SMITH, W. D.; SEGO, D. C. Characterization and use of pulp mill fly ash and lime by-products as road construction amendments. Canadian Journal of Civil Engineering, v.27, p. 581-593, 1999. 
- ANEXO A -

APLICAÇÃO DO MÉTODO DE GRUBBS PARA DETECÇÃO DE OUTLIERS 


\section{Tabela A1 - Identificação de outliers do ensaio de resistência à compressão simples do solo argiloso laterítico}

\begin{tabular}{|c|c|c|c|c|c|c|c|c|c|c|c|c|c|c|}
\hline \multirow{2}{*}{ Solo } & \multirow{2}{*}{$\begin{array}{c}\text { Cura } \\
\text { (Dias) }\end{array}$} & \multirow{2}{*}{$\begin{array}{l}\text { Cal } \\
(\%) \\
\end{array}$} & \multirow{2}{*}{$\begin{array}{c}\text { Resíduo } \\
(\%)\end{array}$} & \multicolumn{3}{|c|}{ Corpo de prova } & \multirow{2}{*}{ Média } & \multirow{2}{*}{$\begin{array}{l}\text { Desvio } \\
\text { padrão }\end{array}$} & \multirow{2}{*}{$\begin{array}{c}\mathrm{G} \\
\text { maior }\end{array}$} & \multirow{2}{*}{$\begin{array}{c}G \\
\text { menor }\end{array}$} & \multirow{2}{*}{$\begin{array}{c}\text { G crítico } \\
95 \%\end{array}$} & \multirow{2}{*}{$\begin{array}{c}\mathrm{Y} \\
\text { máx }\end{array}$} & \multirow{2}{*}{$\begin{array}{c}\mathrm{Y} \\
\text { mín }\end{array}$} & \multirow{2}{*}{$\begin{array}{c}\text { Média } \\
\text { adotada }\end{array}$} \\
\hline & & & & 1 & 2 & 3 & & & & & & & & \\
\hline LG' & 0 & 0 & 0 & 240 & 255 & 279 & 258 & 19,96 & 1,069 & 0,912 & 1,15 & 281 & 235 & 258 \\
\hline LG' & 0 & 3 & 0 & 407 & 415 & 417 & 413 & 5,22 & 0,772 & 1,130 & 1,15 & 419 & 407 & 413 \\
\hline LG' & 0 & 5 & 0 & 419 & 420 & 427 & 422 & 4,13 & 1,154 & 0,614 & 1,15 & 427 & 417 & 420 \\
\hline LG' & 0 & 7 & 0 & 381 & 401 & 400 & 394 & 11,21 & 0,555 & 1,154 & 1,15 & 407 & 381 & 400 \\
\hline LG' & 0 & 10 & 0 & 398 & 408 & 415 & 407 & 8,63 & 0,943 & 1,049 & 1,15 & 417 & 397 & 407 \\
\hline LG' & 0 & 10 & 40 & Des. & Des. & Des. & & & & & 1,15 & & & 0 \\
\hline LGI' & 0 & 10 & 40 & Des. & Des. & Des. & & & & & 1,15 & & & 0 \\
\hline LGI' & 0 & 10 & 0 & Des. & Des. & Des. & & & & & 1,15 & & & 0 \\
\hline LG' & 2 & 10 & 0 & 842 & 864 & 871 & 859 & 15,33 & 0,812 & 1,117 & 1,15 & 876 & 841 & 859 \\
\hline LG' & 2 & 10 & 40 & 464 & 531 & 568 & 521 & 52,79 & 0,892 & 1,081 & 1,15 & 581 & 460 & 521 \\
\hline LGl' & 2 & 10 & 0 & 436 & 626 & 644 & 568 & 115,36 & 0,656 & 1,151 & 1,15 & 701 & 436 & 635 \\
\hline LGI' & 2 & 10 & 40 & 245 & 266 & 334 & 282 & 46,41 & 1,125 & 0,787 & 1,15 & 335 & 228 & 282 \\
\hline LG' & 7 & 0 & 0 & 245 & 261 & 271 & 259 & 13,60 & 0,906 & 1,073 & 1,15 & 275 & 243 & 259 \\
\hline LG' & 7 & 3 & 0 & 488 & 515 & 536 & 513 & 24,24 & 0,948 & 1,045 & 1,15 & 541 & 485 & 513 \\
\hline LG' & 7 & 5 & 0 & 785 & 793 & 806 & 794 & 10,62 & 1,076 & 0,902 & 1,15 & 807 & 782 & 794 \\
\hline LG' & 7 & 7 & 0 & 907 & 946 & 949 & 934 & 23,40 & 0,646 & 1,152 & 1,15 & 961 & $907^{\mathbf{F}}$ & 947 \\
\hline LG' & 7 & 10 & 0 & 1125 & 1133 & 1149 & 1136 & 12,53 & 1,085 & 0,885 & 1,15 & 1150 & 1121 & 1136 \\
\hline LG' & 7 & 0 & 40 & 204 & 216 & 221 & 214 & 8,38 & 0,848 & 1,103 & 1,15 & 223 & 204 & 214 \\
\hline LG' & 7 & 5 & 40 & 422 & 427 & 443 & 431 & 11,30 & 1,130 & 0,770 & 1,15 & 444 & 418 & 431 \\
\hline LG' & 7 & 10 & 40 & 687 & 692 & 714 & 697 & 14,46 & 1,140 & 0,730 & 1,15 & 714 & 681 & 697 \\
\hline LGI' & 7 & 0 & 0 & Des. & Des. & Des. & & & & & 1,15 & & & 0 \\
\hline LGI' & 7 & 5 & 0 & 623 & 643 & 668 & 645 & 22,36 & 1,030 & 0,967 & 1,15 & 670 & 619 & 645 \\
\hline LGI' & 7 & 10 & 0 & 1017 & 1040 & 1052 & 1036 & 17,60 & 0,871 & 1,092 & 1,15 & 1056 & 1016 & 1036 \\
\hline LGI' & 7 & 0 & 40 & Des. & Des. & Des. & & & & & 1,15 & & & 0 \\
\hline LGI' & 7 & 5 & 40 & Des. & Des. & Des. & & & & & 1,15 & & & 0 \\
\hline LGI' & 7 & 10 & 40 & 557 & 559 & 567 & 561 & 5,23 & 1,123 & 0,794 & 1,15 & 567 & 555 & 561 \\
\hline LG' & 28 & 10 & 0 & 1009 & 1150 & 1345 & 1168 & 168,52 & 1,049 & 0,943 & 1,15 & 1362 & 974 & 1168 \\
\hline LG' & 28 & 10 & 40 & 685 & 713 & 759 & 719 & 37,41 & 1,072 & 0,908 & 1,15 & 762 & 676 & 719 \\
\hline LGI' & 28 & 10 & 0 & 1067 & 1073 & 1195 & 1112 & 72,18 & 1,154 & 0,616 & 1,15 & 1195 & 1029 & 1070 \\
\hline LGI' & 28 & 10 & 40 & 578 & 593 & 610 & 594 & 16,01 & 1,007 & 0,993 & 1,15 & 612 & 575 & 594 \\
\hline LG' $^{\prime}$ & 84 & 10 & 0 & 1159 & 1196 & 1232 & 1195 & 36,56 & 0,992 & 1,008 & 1,15 & 1237 & 1153 & 1195 \\
\hline LG' & 84 & 10 & 40 & 741 & 819 & 846 & 802 & 54,69 & 0,805 & 1,120 & 1,15 & 865 & 739 & 802 \\
\hline LGl' & 84 & 10 & 0 & 823 & 1081 & 1093 & 999 & 152,58 & 0,615 & 1,154 & 1,15 & 1174 & 823 & 1087 \\
\hline LGI' & 84 & 10 & 40 & 494 & 604 & 775 & 625 & 141,73 & 1,065 & 0,919 & 1,15 & 787 & 462 & 625 \\
\hline
\end{tabular}




\section{Tabela A2 - Identificação de outliers do ensaio de resistência à} compressão simples do solo argiloso não-laterítico

\begin{tabular}{|c|c|c|c|c|c|c|c|c|c|c|c|c|c|c|}
\hline \multirow{2}{*}{ Solo } & \multirow{2}{*}{$\begin{array}{l}\text { Cura } \\
\text { (Dias) }\end{array}$} & \multirow{2}{*}{$\begin{array}{l}\text { Cal } \\
(\%)\end{array}$} & \multirow{2}{*}{$\begin{array}{c}\text { Resíduo } \\
(\%)\end{array}$} & \multicolumn{3}{|c|}{ Corpo de prova } & \multirow{2}{*}{ Média } & \multirow{2}{*}{$\begin{array}{l}\text { Desvio } \\
\text { padrão }\end{array}$} & \multirow{2}{*}{$\begin{array}{c}\mathrm{G} \\
\text { maior }\end{array}$} & \multirow{2}{*}{$\begin{array}{c}\mathrm{G} \\
\text { menor }\end{array}$} & \multirow{2}{*}{$\begin{array}{c}\text { G crítico } \\
95 \%\end{array}$} & \multirow{2}{*}{$\begin{array}{c}\mathrm{Y} \\
\text { máx }\end{array}$} & \multirow{2}{*}{$\begin{array}{c}\mathrm{Y} \\
\text { mín }\end{array}$} & \multirow{2}{*}{$\begin{array}{c}\text { Média } \\
\text { adotada }\end{array}$} \\
\hline & & & & 1 & 2 & 3 & & & & & & & & \\
\hline NG' & 0 & 0 & 0 & 327 & 329 & 342 & 333 & 8,08 & 1,147 & 0,690 & 1,15 & 342 & 324 & 333 \\
\hline NG' & 0 & 3 & 0 & 280 & 285 & 289 & 285 & 4,39 & 0,957 & 1,038 & 1,15 & 290 & 279 & 285 \\
\hline NG' & 0 & 5 & 0 & 286 & 286 & 288 & 286 & 1,15 & 1,152 & 0,650 & 1,15 & 288 & 285 & 286 \\
\hline NG' & 0 & 7 & 0 & 283 & 283 & 293 & 286 & 5,51 & 1,155 & 0,585 & 1,15 & 293 & 280 & 283 \\
\hline NG' & 0 & 10 & 0 & 319 & 328 & 329 & 325 & 5,78 & 0,656 & 1,151 & 1,15 & 332 & 319 & 329 \\
\hline NG' & 0 & 10 & 40 & Des. & Des. & Des. & & & & & 1,15 & & & 0 \\
\hline NGI' & 0 & 10 & 40 & Des. & Des. & Des. & & & & & 1,15 & & & 0 \\
\hline NGI' & 0 & 10 & 0 & Des. & Des. & Des. & & & & & 1,15 & & & 0 \\
\hline NG' & 2 & 10 & 0 & 715 & 725 & 789 & 743 & 40,04 & 1,147 & 0,692 & 1,15 & 789 & 697 & 743 \\
\hline NG' & 2 & 10 & 40 & 584 & 585 & 658 & 609 & 42,48 & 1,155 & 0,585 & 1,15 & 658 & 560 & 585 \\
\hline NGI' & 2 & 10 & 0 & 592 & 644 & 650 & 629 & 31,58 & 0,673 & 1,149 & 1,15 & 665 & 592 & 629 \\
\hline NGI' & 2 & 10 & 40 & 422 & 439 & 456 & 439 & 16,99 & 0,991 & 1,009 & 1,15 & 458 & 419 & 439 \\
\hline NG' & 7 & 0 & 0 & 330 & 339 & 339 & 336 & 5,10 & 0,615 & 1,154 & 1,15 & 342 & 330 & 339 \\
\hline NG' & 7 & 3 & 0 & 288 & 315 & 317 & 307 & 16,16 & 0,654 & 1,151 & 1,15 & 325 & 288 & 316 \\
\hline NG' & 7 & 5 & 0 & 624 & 647 & 676 & 649 & 25,75 & 1,032 & 0,965 & 1,15 & 679 & 620 & 649 \\
\hline NG' & 7 & 7 & 0 & 1237 & 1275 & 1304 & 1272 & 33,77 & 0,955 & 1,039 & 1,15 & 1311 & 1233 & 1272 \\
\hline NG' & 7 & 10 & 0 & 1495 & 1566 & 1581 & 1547 & 45,96 & 0,732 & 1,139 & 1,15 & 1600 & 1494 & 1547 \\
\hline NG' & 7 & 0 & 40 & 159 & 162 & 162 & 161 & 1,43 & 0,659 & 1,151 & 1,15 & 162 & 159 & 162 \\
\hline NG' & 7 & 5 & 40 & 391 & 406 & 450 & 416 & 30,67 & 1,123 & 0,795 & 1,15 & 451 & 380 & 416 \\
\hline NG' & 7 & 10 & 40 & 764 & 770 & 788 & 774 & 12,76 & 1,125 & 0,788 & 1,15 & 789 & 759 & 774 \\
\hline NGl' & 7 & 0 & 0 & Des. & Des. & Des. & & & & & 1,15 & & & 0 \\
\hline NGl' & 7 & 5 & 0 & 399 & 408 & 445 & 417 & 24,16 & 1,132 & 0,764 & 1,15 & 445 & 389 & 417 \\
\hline NGl' & 7 & 10 & 0 & 1325 & 1361 & 1366 & 1351 & 22,23 & 0,671 & 1,149 & 1,15 & 1376 & 1325 & 1351 \\
\hline NGI' & 7 & 0 & 40 & Des. & Des. & Des. & & & & & 1,15 & & & 0 \\
\hline NGI' & 7 & 5 & 40 & 143 & 174 & 267 & 195 & 64,41 & 1,120 & 0,803 & 1,15 & 269 & 121 & 195 \\
\hline NGI' & 7 & 10 & 40 & 473 & 506 & 572 & 517 & 50,56 & 1,093 & 0,870 & 1,15 & 575 & 459 & 517 \\
\hline NG' & 28 & 10 & 0 & 2398 & 2419 & 2419 & 2412 & 11,95 & 0,579 & 1,155 & 1,15 & 2425 & 2398 & 2419 \\
\hline NG' & 28 & 10 & 40 & 1058 & 1125 & 1311 & 1165 & 131,17 & 1,116 & 0,814 & 1,15 & 1316 & 1014 & 1165 \\
\hline NGI' & 28 & 10 & 0 & 1660 & 1875 & 1929 & 1821 & 142,18 & 0,757 & 1,134 & 1,15 & 1985 & 1658 & 1821 \\
\hline NGl' & 28 & 10 & 40 & 692 & 835 & 875 & 801 & 96,28 & 0,770 & 1,130 & 1,15 & 911 & 690 & 801 \\
\hline NG' & 84 & 10 & 0 & 2555 & 2880 & 2982 & 2806 & 222,67 & 0,791 & 1,124 & 1,15 & 3062 & 2550 & 2806 \\
\hline NG' & 84 & 10 & 40 & 1252 & 1331 & 1375 & 1319 & 62,48 & 0,895 & 1,080 & 1,15 & 1391 & 1247 & 1319 \\
\hline NGI' & 84 & 10 & 0 & 2264 & 2306 & 2442 & 2338 & 93,07 & 1,125 & 0,787 & 1,15 & 2445 & 2231 & 2338 \\
\hline NGl' & 84 & 10 & 40 & 1032 & 1175 & 1179 & 1129 & 84,09 & 0,601 & 1,154 & 1,15 & 1226 & 1032 & 1177 \\
\hline
\end{tabular}




\section{Tabela A3 - Identificação de outliers do módulo tangente inicial do solo argiloso laterítico}

\begin{tabular}{|c|c|c|c|c|c|c|c|c|c|c|c|c|c|c|}
\hline \multirow{2}{*}{ Solo } & \multirow{2}{*}{$\begin{array}{l}\text { Cura } \\
\text { (Dias) }\end{array}$} & \multirow{2}{*}{$\begin{array}{l}\text { Cal } \\
(\%)\end{array}$} & \multirow{2}{*}{$\begin{array}{c}\text { Resíduo } \\
(\%)\end{array}$} & \multicolumn{3}{|c|}{ Corpo de prova } & \multirow{2}{*}{ Média } & \multirow{2}{*}{$\begin{array}{l}\text { Desvio } \\
\text { padrão }\end{array}$} & \multirow{2}{*}{$\begin{array}{c}\mathrm{G} \\
\text { maior }\end{array}$} & \multirow{2}{*}{$\begin{array}{c}\mathrm{G} \\
\text { menor }\end{array}$} & \multirow{2}{*}{$\begin{array}{c}\text { G crítico } \\
95 \%\end{array}$} & \multirow{2}{*}{$\begin{array}{c}\text { Y } \\
\text { máx }\end{array}$} & \multirow{2}{*}{$\begin{array}{c}\text { Y } \\
\text { mín }\end{array}$} & \multirow{2}{*}{$\begin{array}{c}\text { Média } \\
\text { adotada }\end{array}$} \\
\hline & & & & 1 & 2 & 3 & & & & & & & & \\
\hline LG' & 0 & 0 & 0 & 57 & 63 & 76 & 65 & 9,71 & 1,098 & 0,858 & 1,15 & 77 & 54 & 65 \\
\hline LG' & 0 & 3 & 0 & 104 & 109 & 110 & 108 & 3,21 & 0,726 & 1,141 & 1,15 & 111 & 104 & 108 \\
\hline LG' & 0 & 5 & 0 & 92 & 101 & 107 & 100 & 7,55 & 0,927 & 1,060 & 1,15 & 109 & 91 & 100 \\
\hline LG' & 0 & 7 & 0 & 90 & 91 & 97 & 93 & 3,79 & 1,145 & 0,704 & 1,15 & 97 & 88 & 93 \\
\hline LG' & 0 & 10 & 0 & 91 & 97 & 103 & 97 & 6,00 & 1,000 & 1,000 & 1,15 & 104 & 90 & 97 \\
\hline LG' & 0 & 10 & 40 & Des. & Des. & Des. & & & & & 1,15 & & & 0 \\
\hline LGI' & 0 & 10 & 40 & Des. & Des. & Des. & & & & & 1,15 & & & 0 \\
\hline LGI' & 0 & 10 & 0 & Des. & Des. & Des. & & & & & 1,15 & & & 0 \\
\hline LG' & 2 & 10 & 0 & 155 & 340 & 358 & 284 & 112,37 & 0,656 & 1,151 & 1,15 & 414 & 155 & 349 \\
\hline LG' & 2 & 10 & 40 & 178 & 235 & 287 & 233 & 54,52 & 0,984 & 1,015 & 1,15 & 296 & 171 & 233 \\
\hline LGI' & 2 & 10 & 0 & 55 & 200 & 214 & 156 & 88,04 & 0,655 & 1,151 & 1,15 & 258 & 55 & 207 \\
\hline LGI' & 2 & 10 & 40 & 134 & 207 & 210 & 184 & 43,04 & 0,612 & 1,154 & 1,15 & 233 & 134 & 209 \\
\hline LG' & 7 & 0 & 0 & 63 & 70 & 75 & 69 & 6,03 & 0,940 & 1,051 & 1,15 & 76 & 62 & 69 \\
\hline LG' & 7 & 3 & 0 & 191 & 204 & 219 & 205 & 14,01 & 1,023 & 0,975 & 1,15 & 221 & 189 & 205 \\
\hline LG' & 7 & 5 & 0 & 469 & 475 & 498 & 481 & 15,31 & 1,132 & 0,762 & 1,15 & 498 & 463 & 481 \\
\hline LG' & 7 & 7 & 0 & 700 & 762 & 825 & 762 & 62,50 & 1,003 & 0,997 & 1,15 & 834 & 690 & 762 \\
\hline LG' & 7 & 10 & 0 & 848 & 958 & 960 & 922 & 64,09 & 0,593 & 1,155 & 1,15 & 996 & 848 & 959 \\
\hline LG' & 7 & 0 & 40 & 22 & 27 & 29 & 26 & 3,61 & 0,832 & 1,109 & 1,15 & 30 & 22 & 26 \\
\hline LG' & 7 & 5 & 40 & 59 & 60 & 62 & 60 & 1,53 & 1,091 & 0,873 & 1,15 & 62 & 59 & 60 \\
\hline LG' & 7 & 10 & 40 & 357 & 390 & 420 & 389 & 31,51 & 0,984 & 1,015 & 1,15 & 425 & 353 & 389 \\
\hline LGI' & 7 & 0 & 0 & Des. & Des. & Des. & & & & & 1,15 & & & 0 \\
\hline LGI' & 7 & 5 & 0 & 445 & 447 & 480 & 457 & 19,66 & 1,153 & 0,627 & 1,15 & 480 & 435 & 446 \\
\hline LGI' & 7 & 10 & 0 & 406 & 676 & 677 & 586 & 156,17 & 0,581 & 1,155 & 1,15 & 766 & 407 & 677 \\
\hline LGI' & 7 & 0 & 40 & Des. & Des. & Des. & & & & & 1,15 & & & 0 \\
\hline LGI' & 7 & 5 & 40 & Des. & Des. & Des. & & & & & 1,15 & & & 0 \\
\hline LGI' & 7 & 10 & 40 & 333 & 352 & 352 & 346 & 10,97 & 0,577 & 1,155 & 1,15 & 358 & 333 & 352 \\
\hline LG' & 28 & 10 & 0 & 213 & 978 & 1049 & 747 & 463,53 & 0,652 & 1,151 & 1,15 & 1280 & 214 & 1014 \\
\hline LG' & 28 & 10 & 40 & 276 & 422 & 429 & 376 & 86,38 & 0,617 & 1,154 & 1,15 & 475 & 276 & 426 \\
\hline LGI' & 28 & 10 & 0 & 436 & 734 & 740 & 637 & 173,81 & 0,595 & 1,155 & 1,15 & 837 & 437 & 737 \\
\hline LGI' & 28 & 10 & 40 & 367 & 391 & 400 & 386 & 17,06 & 0,821 & 1,114 & 1,15 & 406 & 366 & 386 \\
\hline $\mathrm{LG}^{\prime}$ & 84 & 10 & 0 & 1064 & 1117 & 1196 & 1126 & 66,43 & 1,059 & 0,928 & 1,15 & 1202 & 1049 & 1157 \\
\hline LG' & 84 & 10 & 40 & 215 & 474 & 482 & 390 & 151,90 & 0,603 & 1,154 & 1,15 & 565 & 216 & 478 \\
\hline LGI' & 84 & 10 & 0 & 680 & 881 & 881 & 814 & 116,05 & 0,577 & 1,155 & 1,15 & 947 & 681 & 881 \\
\hline LGI' & 84 & 10 & 40 & 250 & 368 & 665 & 428 & 213,84 & 1,110 & 0,831 & 1,15 & 674 & 182 & 428 \\
\hline
\end{tabular}

LG' - Ensaio Realizado com Solo Laterítico Argiloso sem Imersão

LGI' - Ensaio Realizado com Solo Laterítico Argiloso com Imersão

Des. - Corpos-de-Prova Desintegrados

- Outliers 
Tabela A4 - Identificação de outliers do módulo tangente inicial do solo argiloso não-laterítico

\begin{tabular}{|c|c|c|c|c|c|c|c|c|c|c|c|c|c|c|}
\hline \multirow{2}{*}{ Solo } & \multirow{2}{*}{$\begin{array}{c}\text { Cura } \\
\text { (Dias) }\end{array}$} & \multirow{2}{*}{$\begin{array}{l}\text { Cal } \\
(\%)\end{array}$} & \multirow{2}{*}{$\begin{array}{c}\text { Resíduo } \\
(\%)\end{array}$} & \multicolumn{3}{|c|}{ Corpo de prova } & \multirow{2}{*}{ Média } & \multirow{2}{*}{$\begin{array}{l}\text { Desvio } \\
\text { padrão }\end{array}$} & \multirow{2}{*}{$\begin{array}{c}\mathrm{G} \\
\text { maior }\end{array}$} & \multirow{2}{*}{$\begin{array}{c}\mathrm{G} \\
\text { menor }\end{array}$} & \multirow{2}{*}{$\begin{array}{c}\text { G crítico } \\
95 \%\end{array}$} & \multirow{2}{*}{$\begin{array}{c}\mathrm{Y} \\
\text { máx }\end{array}$} & \multirow{2}{*}{$\begin{array}{c}\mathrm{Y} \\
\text { mín }\end{array}$} & \multirow{2}{*}{$\begin{array}{c}\text { Média } \\
\text { adotada }\end{array}$} \\
\hline & & & & 1 & 2 & 3 & & & & & & & & \\
\hline NG' & 0 & 0 & 0 & 43 & 46 & 49 & 46 & 3,00 & 1,000 & 1,000 & 1,15 & 49 & 43 & 46 \\
\hline NG' & 0 & 3 & 0 & 44 & 50 & 52 & 49 & 4,16 & 0,801 & 1,121 & 1,15 & 53 & 44 & 49 \\
\hline NG' & 0 & 5 & 0 & 48 & 54 & 60 & 54 & 6,00 & 1,000 & 1,000 & 1,15 & 61 & 47 & 54 \\
\hline NG' & 0 & 7 & 0 & 47 & 48 & 51 & 49 & 2,08 & 1,121 & 0,801 & 1,15 & 51 & 46 & 49 \\
\hline NG' & 0 & 10 & 0 & 54 & 57 & 58 & 56 & 2,08 & 0,801 & 1,121 & 1,15 & 59 & 54 & 56 \\
\hline NG' & 0 & 10 & 40 & Des. & Des. & Des. & & & & & 1,15 & & & 0 \\
\hline NGl' & 0 & 10 & 40 & Des. & Des. & Des. & & & & & 1,15 & & & 0 \\
\hline NGI' & 0 & 10 & 0 & Des. & Des. & Des. & & & & & 1,15 & & & 0 \\
\hline NG' & 2 & 10 & 0 & 113 & 193 & 361 & 222 & 126,58 & 1,096 & 0,864 & 1,15 & 368 & 77 & 222 \\
\hline NG' & 2 & 10 & 40 & 86 & 105 & 125 & 105 & 19,50 & 1,008 & 0,991 & 1,15 & 128 & 83 & 105 \\
\hline NGI' & 2 & 10 & 0 & 129 & 133 & 136 & 133 & 3,51 & 0,949 & 1,044 & 1,15 & 137 & 129 & 133 \\
\hline NGI' & 2 & 10 & 40 & 91 & 92 & 201 & 128 & 63,22 & 1,155 & 0,585 & 1,15 & 201 & 55 & 92 \\
\hline NG' & 7 & 0 & 0 & 67 & 73 & 74 & 71 & 3,79 & 0,704 & 1,145 & 1,15 & 76 & 67 & 71 \\
\hline NG' & 7 & 3 & 0 & 133 & 139 & 169 & 147 & 19,29 & 1,141 & 0,726 & 1,15 & 169 & 125 & 147 \\
\hline NG' & 7 & 5 & 0 & 276 & 293 & 357 & 309 & 42,71 & 1,132 & 0,765 & 1,15 & 358 & 260 & 309 \\
\hline NG' & 7 & 7 & 0 & 895 & 987 & 1001 & 961 & 57,58 & 0,695 & 1,146 & 1,15 & 1027 & 895 & 961 \\
\hline NG' & 7 & 10 & 0 & 1234 & 1375 & 1420 & 1343 & 97,04 & 0,793 & 1,123 & 1,15 & 1455 & 1231 & 1343 \\
\hline NG' & 7 & 0 & 40 & 10 & 11 & 14 & 12 & 2,08 & 1,121 & 0,801 & 1,15 & 14 & 9 & 12 \\
\hline NG' & 7 & 5 & 40 & 81 & 90 & 99 & 90 & 9,00 & 1,000 & 1,000 & 1,15 & 100 & 80 & 90 \\
\hline NG' & 7 & 10 & 40 & 227 & 252 & 259 & 246 & 16,82 & 0,773 & 1,129 & 1,15 & 265 & 227 & 246 \\
\hline NGI' & 7 & 0 & 0 & Des. & Des. & Des. & & & & & 1,15 & 0 & 0 & 0 \\
\hline NGI' & 7 & 5 & 0 & 299 & 300 & 357 & 319 & 33,20 & 1,155 & 0,592 & 1,15 & 357 & 280 & 300 \\
\hline NGI' & 7 & 10 & 0 & 1249 & 1252 & 1584 & 1362 & 192,55 & 1,155 & 0,585 & 1,15 & 1583 & 1140 & 1251 \\
\hline NGI' & 7 & 0 & 40 & Des. & Des. & Des. & & & & & 1,15 & 0 & 0 & 0 \\
\hline NGI' & 7 & 5 & 40 & 63 & 65 & 138 & 89 & 42,74 & 1,154 & 0,601 & 1,15 & 138 & 40 & 64 \\
\hline NGI' & 7 & 10 & 40 & 198 & 211 & 343 & 251 & 80,23 & 1,151 & 0,656 & 1,15 & 343 & 158 & 205 \\
\hline NG' & 28 & 10 & 0 & 1821 & 1869 & 1915 & 1868 & 47,00 & 0,993 & 1,007 & 1,15 & 1922 & 1814 & 1892 \\
\hline NG' & 28 & 10 & 40 & 613 & 684 & 878 & 725 & 137,18 & 1,115 & 0,816 & 1,15 & 883 & 567 & 725 \\
\hline NGI' & 28 & 10 & 0 & 491 & 1349 & 1362 & 1067 & 499,16 & 0,590 & 1,155 & 1,15 & 1641 & 493 & 1356 \\
\hline NGI' & 28 & 10 & 40 & 625 & 665 & 1075 & 788 & 249,06 & 1,151 & 0,656 & 1,15 & 1075 & 502 & 645 \\
\hline NG' & 84 & 10 & 0 & 1820 & 2130 & 5140 & 3030 & 1833,88 & 1,151 & 0,660 & 1,15 & 5139 & 921 & 1975 \\
\hline NG' & 84 & 10 & 40 & 971 & 1061 & 1138 & 1057 & 83,58 & 0,973 & 1,025 & 1,15 & 1153 & 961 & 1057 \\
\hline NGI' & 84 & 10 & 0 & 1252 & 1344 & 1630 & 1409 & 197,12 & 1,123 & 0,795 & 1,15 & 1635 & 1182 & 1409 \\
\hline $\mathrm{NGI}$ & 84 & 10 & 40 & 809 & 918 & 2006 & 1244 & 661,87 & 1,151 & 0,658 & 1,15 & 2005 & 483 & 864 \\
\hline
\end{tabular}

NG' - Ensaio Realizado com Solo Não-Laterítico Argiloso sem Imersão

NGl' - Ensaio Realizado com Solo Não-Laterítico Argiloso com Imersão

Des. - Corpos-de-Prova Desintegrados

- Outliers 
Tabela A5 - Identificação de outliers do ensaio de resistência à tração indireta do solo argiloso laterítico

\begin{tabular}{|c|c|c|c|c|c|c|c|c|c|c|c|c|c|c|}
\hline \multirow{2}{*}{ Solo } & \multirow{2}{*}{ 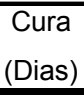 } & \multirow{2}{*}{$\begin{array}{l}\text { Cal } \\
(\%)\end{array}$} & \multirow{2}{*}{$\begin{array}{c}\text { Resíduo } \\
\text { (\%) }\end{array}$} & \multicolumn{3}{|c|}{ Corpo de prova } & \multirow{2}{*}{ Média } & \multirow{2}{*}{$\begin{array}{l}\text { Desvio } \\
\text { padrão }\end{array}$} & \multirow{2}{*}{$\begin{array}{c}\mathrm{G} \\
\text { maior }\end{array}$} & \multirow{2}{*}{$\begin{array}{c}\mathrm{G} \\
\text { menor }\end{array}$} & \multirow{2}{*}{$\begin{array}{c}\text { G crítico } \\
95 \%\end{array}$} & \multirow{2}{*}{$\begin{array}{c}\mathrm{Y} \\
\text { máx }\end{array}$} & \multirow{2}{*}{$\begin{array}{c}\mathrm{Y} \\
\text { mín }\end{array}$} & \multirow{2}{*}{$\begin{array}{l}\text { Média } \\
\text { adotada }\end{array}$} \\
\hline & & & & 1 & 2 & 3 & & & & & & & & \\
\hline LG' & 0 & 0 & 0 & Des. & Des. & Des. & & & & & 1,15 & & & 0 \\
\hline LG' & 0 & 3 & 0 & Des. & Des. & Des. & & & & & 1,15 & & & 0 \\
\hline LG' & 0 & 5 & 0 & Des. & Des. & Des. & & & & & 1,15 & & & 0 \\
\hline LG' & 0 & 7 & 0 & Des. & Des. & Des. & & & & & 1,15 & & & 0 \\
\hline LG' & 0 & 10 & 0 & Des. & Des. & Des. & & & & & 1,15 & & & 0 \\
\hline LG' & 0 & 10 & 40 & Des. & Des. & Des. & & & & & 1,15 & & & 0 \\
\hline LGI' & 0 & 10 & 40 & Des. & Des. & Des. & & & & & 1,15 & & & 0 \\
\hline LGI' & 0 & 10 & 0 & Des. & Des. & Des. & & & & & 1,15 & & & 0 \\
\hline LG' & 2 & 10 & 0 & 103 & 106 & 112 & 107 & 4,37 & 1,091 & 0,873 & 1,15 & 112 & 102 & 107 \\
\hline LG' & 2 & 10 & 40 & 94 & 100 & 106 & 100 & 6,03 & 0,996 & 1,004 & 1,15 & 107 & 93 & 100 \\
\hline LGI' & 2 & 10 & 0 & 69 & 69 & 74 & 71 & 3,31 & 1,155 & 0,577 & 1,15 & 74 & 67 & 69 \\
\hline LGI' & 2 & 10 & 40 & 58 & 63 & 63 & 61 & 3,25 & 0,615 & 1,154 & 1,15 & 65 & 58 & 63 \\
\hline LG' & 7 & 0 & 0 & 23 & 23 & 29 & 25 & 3,12 & 1,154 & 0,596 & 1,15 & 29 & 21 & 23 \\
\hline LG' & 7 & 5 & 0 & 87 & 92 & 92 & 90 & 3,23 & 0,634 & 1,153 & 1,15 & 94 & 87 & 92 \\
\hline LG' & 7 & 10 & 0 & 139 & 144 & 144 & 142 & 3,30 & 0,641 & 1,152 & 1,15 & 146 & 139 & 144 \\
\hline LG' & 7 & 0 & 40 & 23 & 26 & 26 & 25 & 1,69 & 0,577 & 1,155 & 1,15 & 27 & 23 & 26 \\
\hline LG' & 7 & 5 & 40 & 34 & 34 & 40 & 36 & 3,35 & 1,154 & 0,619 & 1,15 & 40 & 32 & 34 \\
\hline LG' & 7 & 10 & 40 & 115 & 115 & 120 & 117 & 2,75 & 1,152 & 0,638 & 1,15 & 120 & 114 & 115 \\
\hline LGI' & 7 & 0 & 0 & Des. & Des. & Des. & & & & & 1,15 & & & 0 \\
\hline LGI' & 7 & 5 & 0 & 63 & 63 & 69 & 65 & 3,46 & 1,154 & 0,622 & 1,15 & 69 & 61 & 63 \\
\hline LGI' & 7 & 10 & 0 & 115 & 121 & 126 & 121 & 5,50 & 0,985 & 1,015 & 1,15 & 127 & 114 & 121 \\
\hline LGI' & 7 & 0 & 40 & Des. & Des. & Des. & & & & & 1,15 & & & 0 \\
\hline LGI' & 7 & 5 & 40 & Des. & Des. & Des. & & & & & 1,15 & & & 0 \\
\hline LGI' & 7 & 10 & 40 & 83 & 86 & 92 & 87 & 4,47 & 1,079 & 0,896 & 1,15 & 92 & 82 & 87 \\
\hline LG' & 28 & 10 & 0 & 138 & 150 & 162 & 150 & 11,67 & 0,996 & 1,004 & 1,15 & 163 & 137 & 150 \\
\hline LG' & 28 & 10 & 40 & 155 & 161 & 166 & 161 & 5,90 & 0,991 & 1,009 & 1,15 & 167 & 154 & 161 \\
\hline LGI' & 28 & 10 & 0 & 130 & 130 & 130 & 130 & 0,03 & 1,060 & 0,927 & 1,15 & 130 & 130 & 130 \\
\hline LGI' & 28 & 10 & 40 & 115 & 126 & 132 & 124 & 8,78 & 0,861 & 1,097 & 1,15 & 134 & 114 & 124 \\
\hline LG' & 84 & 10 & 0 & 162 & 179 & 202 & 181 & 20,27 & 1,044 & 0,949 & 1,15 & 204 & 158 & 181 \\
\hline LG' & 84 & 10 & 40 & 154 & 166 & 172 & 164 & 9,12 & 0,847 & 1,103 & 1,15 & 175 & 154 & 164 \\
\hline LGI' & 84 & 10 & 0 & 150 & 153 & 156 & 153 & 2,89 & 0,963 & 1,033 & 1,15 & 156 & 149 & 153 \\
\hline LGI' & 84 & 10 & 40 & 143 & 143 & 149 & 145 & 3,14 & 1,155 & 0,577 & 1,15 & 149 & 141 & 143 \\
\hline
\end{tabular}

LG' - Ensaio Realizado com Solo Laterítico Argiloso sem Imersão

LGI' - Ensaio Realizado com Solo Laterítico Argiloso com Imersão

Des. - Corpos-de-Prova Desintegrados

Des. - Corpos
- Outliers 
Tabela A6 - Identificação de outliers do ensaio de resistência à tração indireta do solo argiloso não-laterítico

\begin{tabular}{|c|c|c|c|c|c|c|c|c|c|c|c|c|c|c|}
\hline \multirow{2}{*}{ Solo } & \multirow{2}{*}{$\begin{array}{l}\text { Cura } \\
\text { (Dias) }\end{array}$} & \multirow{2}{*}{$\begin{array}{l}\text { Cal } \\
(\%)\end{array}$} & \multirow{2}{*}{$\begin{array}{c}\text { Resíduo } \\
(\%)\end{array}$} & \multicolumn{3}{|c|}{ Corpo de prova } & \multirow{2}{*}{ Média } & \multirow{2}{*}{$\begin{array}{l}\text { Desvio } \\
\text { padrão }\end{array}$} & \multirow{2}{*}{$\begin{array}{c}\mathrm{G} \\
\text { maior }\end{array}$} & \multirow{2}{*}{$\begin{array}{c}\mathrm{G} \\
\text { menor }\end{array}$} & \multirow{2}{*}{$\begin{array}{c}\text { G crítico } \\
95 \%\end{array}$} & \multirow{2}{*}{$\begin{array}{c}\mathrm{Y} \\
\text { máx }\end{array}$} & \multirow{2}{*}{$\begin{array}{c}\mathrm{Y} \\
\text { mín }\end{array}$} & \multirow{2}{*}{$\begin{array}{l}\text { Média } \\
\text { adotada }\end{array}$} \\
\hline & & & & 1 & 2 & 3 & & & & & & & & \\
\hline NG' & 0 & 0 & 0 & 0 & 0 & 0 & 0 & 0,00 & & & 1,15 & 0 & 0 & 0 \\
\hline NG' & 0 & 3 & 0 & 0 & 0 & 0 & 0 & 0,00 & & & 1,15 & 0 & 0 & 0 \\
\hline NG' & 0 & 5 & 0 & 0 & 0 & 0 & 0 & 0,00 & & & 1,15 & 0 & 0 & 0 \\
\hline NG' & 0 & 7 & 0 & 0 & 0 & 0 & 0 & 0,00 & & & 1,15 & 0 & 0 & 0 \\
\hline NG' & 0 & 10 & 0 & 0 & 0 & 0 & 0 & 0,00 & & & 1,15 & 0 & 0 & 0 \\
\hline NG' & 0 & 10 & 40 & 0 & 0 & 0 & 0 & 0,00 & & & 1,15 & 0 & 0 & 0 \\
\hline NGl' & 0 & 10 & 40 & Des. & Des. & Des. & 0 & 0,00 & & & 1,15 & 0 & 0 & 0 \\
\hline NGl' & 0 & 10 & 0 & Des. & Des. & Des. & 0 & 0,00 & & & 1,15 & 0 & 0 & 0 \\
\hline NG' & 2 & 10 & 0 & 91 & 92 & 95 & 93 & 1,62 & 1,138 & 0,739 & 1,15 & 95 & 91 & 93 \\
\hline NG' & 2 & 10 & 40 & 68 & 68 & 74 & 70 & 3,17 & 1,154 & 0,598 & 1,15 & 74 & 67 & 68 \\
\hline NGl' & 2 & 10 & 0 & 81 & 83 & 86 & 83 & 2,88 & 1,035 & 0,960 & 1,15 & 87 & 80 & 83 \\
\hline NGI' & 2 & 10 & 40 & 48 & 51 & 54 & 51 & 2,84 & 0,988 & 1,012 & 1,15 & 54 & 48 & 51 \\
\hline NG' & 7 & 0 & 0 & 29 & 34 & 34 & 32 & 3,29 & 0,577 & 1,155 & 1,15 & 36 & 29 & 34 \\
\hline NG' & 7 & 3 & 0 & 0 & 0 & 0 & 0 & 0,00 & & & 1,15 & 0 & 0 & 0 \\
\hline NG' & 7 & 5 & 0 & 74 & 80 & 86 & 80 & 5,71 & 0,991 & 1,009 & 1,15 & 86 & 73 & 80 \\
\hline NG' & 7 & 7 & 0 & 0 & 0 & 0 & 0 & 0,00 & & & 1,15 & 0 & 0 & 0 \\
\hline NG' & 7 & 10 & 0 & 172 & 177 & 190 & 180 & 9,21 & 1,104 & 0,844 & 1,15 & 190 & 169 & 180 \\
\hline NG' & 7 & 0 & 40 & 11 & 11 & 11 & 11 & 0,01 & 1,000 & 1,000 & 1,15 & 11 & 11 & 11 \\
\hline NG' & 7 & 5 & 40 & 57 & 62 & 68 & 62 & 5,72 & 1,003 & 0,996 & 1,15 & 69 & 56 & 62 \\
\hline NG' & 7 & 10 & 40 & 113 & 119 & 125 & 119 & 5,66 & 1,000 & 1,000 & 1,15 & 125 & 112 & 119 \\
\hline NGl' & 7 & 0 & 0 & Des. & Des. & Des. & 0 & 0,00 & & & 1,15 & 0 & 0 & 0 \\
\hline NGI' & 7 & 5 & 0 & 46 & 46 & 46 & 46 & 0,03 & 0,927 & 1,060 & 1,15 & 46 & 46 & 46 \\
\hline NGI' & 7 & 10 & 0 & 165 & 166 & 166 & 166 & 0,50 & 1,094 & 0,867 & 1,15 & 166 & 165 & 166 \\
\hline NGI' & 7 & 0 & 40 & Des. & Des. & Des. & 0 & 0,00 & & & 1,15 & 0 & 0 & 0 \\
\hline NGI' & 7 & 5 & 40 & 28 & 34 & 40 & 34 & 5,73 & 0,993 & 1,007 & 1,15 & 41 & 27 & 34 \\
\hline NGI' & 7 & 10 & 40 & 63 & 79 & 85 & 76 & 11,65 & 0,803 & 1,120 & 1,15 & 89 & 62 & 76 \\
\hline NG' & 28 & 10 & 0 & 309 & 315 & 326 & 317 & 8,67 & 1,075 & 0,903 & 1,15 & 327 & 307 & 317 \\
\hline NG' & 28 & 10 & 40 & 211 & 216 & 222 & 216 & 5,70 & 1,000 & 1,000 & 1,15 & 223 & 210 & 216 \\
\hline NGI' & 28 & 10 & 0 & 275 & 298 & 303 & 292 & 14,93 & 0,741 & 1,138 & 1,15 & 309 & 275 & 292 \\
\hline NGI' & 28 & 10 & 40 & 142 & 154 & 159 & 152 & 8,68 & 0,881 & 1,087 & 1,15 & 162 & 142 & 152 \\
\hline NG' & 84 & 10 & 0 & 325 & 349 & 377 & 351 & 26,07 & 1,023 & 0,975 & 1,15 & 381 & 321 & 351 \\
\hline NG' & 84 & 10 & 40 & 295 & 301 & 306 & 301 & 5,68 & 1,001 & 0,999 & 1,15 & 307 & 294 & 301 \\
\hline NGI' & 84 & 10 & 0 & 332 & 332 & 366 & 343 & 19,62 & 1,155 & 0,594 & 1,15 & 366 & 321 & 332 \\
\hline NGI' & 84 & 10 & 40 & 205 & 210 & 222 & 212 & 8,68 & 1,091 & 0,873 & 1,15 & 222 & 202 & 212 \\
\hline
\end{tabular}

NG' - Ensaio Realizado com Solo Não-Laterítico Argiloso sem Imersão

NGI' - Ensaio Realizado com Solo Não-Laterítico Argiloso com Imersão

Des. - Corpos-de-Prova Desintegrados

- Outliers 
Tabela A7 - Identificação de outliers do ensaio de resistência à compressão simples do solo arenoso laterítico

\begin{tabular}{|c|c|c|c|c|c|c|c|c|c|c|c|c|c|c|}
\hline \multirow{2}{*}{ Solo } & \multirow{2}{*}{$\begin{array}{c}\text { Cura } \\
\text { (Dias) }\end{array}$} & \multirow{2}{*}{$\begin{array}{l}\text { Cal } \\
(\%)\end{array}$} & \multirow{2}{*}{$\begin{array}{c}\text { Resíduo } \\
\text { (\%) }\end{array}$} & \multicolumn{3}{|c|}{ Corpo de prova } & \multirow{2}{*}{ Média } & \multirow{2}{*}{$\begin{array}{l}\text { Desvio } \\
\text { padrão }\end{array}$} & \multirow{2}{*}{$\begin{array}{c}\mathrm{G} \\
\text { maior }\end{array}$} & \multirow{2}{*}{$\begin{array}{c}\mathrm{G} \\
\text { menor }\end{array}$} & \multirow{2}{*}{$\begin{array}{c}\text { G crítico } \\
95 \%\end{array}$} & \multirow{2}{*}{$\begin{array}{c}\mathrm{Y} \\
\text { máx }\end{array}$} & \multirow{2}{*}{$\begin{array}{c}\mathrm{Y} \\
\min \end{array}$} & \multirow{2}{*}{$\begin{array}{c}\text { Média } \\
\text { adotada }\end{array}$} \\
\hline & & & & 1 & 2 & 3 & & & & & & & & \\
\hline $\mathrm{LA}^{\prime}$ & 7 & 0 & 40 & 144 & 146 & 151 & 147 & 3,40 & 1,114 & 0,820 & 1,15 & 151 & 143 & 147 \\
\hline LA' & 7 & 5 & 40 & 230 & 234 & 237 & 234 & 3,72 & 0,907 & 1,072 & 1,15 & 238 & 229 & 234 \\
\hline LA' $^{\prime}$ & 7 & 10 & 40 & 208 & 210 & 227 & 215 & 10,40 & 1,146 & 0,695 & 1,15 & 227 & 203 & 215 \\
\hline
\end{tabular}

LA' - Ensaio Realizado com Solo Laterítico Arenoso sem Imersão - Outliers

Tabela A8 - Identificação de outliers do módulo tangente do solo arenoso laterítico

\begin{tabular}{|c|c|c|c|c|c|c|c|c|c|c|c|c|c|c|}
\hline \multirow{2}{*}{ Solo } & \multirow{2}{*}{$\begin{array}{l}\text { Cura } \\
\text { (Dias) }\end{array}$} & \multirow{2}{*}{$\begin{array}{l}\text { Cal } \\
(\%)\end{array}$} & \multirow{2}{*}{$\begin{array}{c}\text { Resíduo } \\
\text { (\%) }\end{array}$} & \multicolumn{3}{|c|}{ Corpo de prova } & \multirow{2}{*}{ Média } & \multirow{2}{*}{$\begin{array}{l}\text { Desvio } \\
\text { padrão }\end{array}$} & \multirow{2}{*}{$\begin{array}{c}\mathrm{G} \\
\text { maior }\end{array}$} & \multirow{2}{*}{$\begin{array}{c}\mathrm{G} \\
\text { menor }\end{array}$} & \multirow{2}{*}{$\begin{array}{c}\text { G crítico } \\
95 \%\end{array}$} & \multirow{2}{*}{$\begin{array}{c}\mathrm{Y} \\
\text { máx }\end{array}$} & \multirow{2}{*}{$\begin{array}{c}\mathrm{Y} \\
\text { mín }\end{array}$} & \multirow{2}{*}{$\begin{array}{c}\text { Média } \\
\text { adotada }\end{array}$} \\
\hline & & & & 1 & 2 & 3 & & & & & & & & \\
\hline LA' $^{\prime}$ & 7 & 0 & 40 & 11 & 13 & 16 & 13 & 2,52 & 1,060 & 0,927 & 1,15 & 16 & 10 & 13 \\
\hline LA' $^{\prime}$ & 7 & 5 & 40 & 38 & 41 & 42 & 40 & 2,08 & 0,801 & 1,121 & 1,15 & 43 & 38 & 40 \\
\hline LA' $^{\prime}$ & 7 & 10 & 40 & 33 & 35 & 38 & 35 & 2,52 & 1,060 & 0,927 & 1,15 & 38 & 32 & 35 \\
\hline
\end{tabular}

LA' - Ensaio Realizado com Solo Laterítico Arenoso sem Imersão - Outliers

Tabela A9 - Identificação de outliers do ensaio de tração indireta do solo arenoso laterítico

\begin{tabular}{|c|c|c|c|c|c|c|c|c|c|c|c|c|c|c|}
\hline \multirow{2}{*}{ Solo } & \multirow{2}{*}{$\begin{array}{l}\text { Cura } \\
\text { (Dias) }\end{array}$} & \multirow{2}{*}{$\begin{array}{l}\text { Cal } \\
(\%) \\
\end{array}$} & \multirow{2}{*}{$\begin{array}{c}\text { Resíduo } \\
\text { (\%) }\end{array}$} & \multicolumn{3}{|c|}{ Corpo de prova } & \multirow{2}{*}{ Média } & \multirow{2}{*}{$\begin{array}{l}\text { Desvio } \\
\text { padrão }\end{array}$} & \multirow{2}{*}{$\begin{array}{c}\mathrm{G} \\
\text { maior }\end{array}$} & \multirow{2}{*}{$\begin{array}{c}\mathrm{G} \\
\text { menor }\end{array}$} & \multirow{2}{*}{$\begin{array}{c}\text { G crítico } \\
95 \%\end{array}$} & \multirow{2}{*}{$\begin{array}{c}\mathrm{Y} \\
\text { máx }\end{array}$} & \multirow{2}{*}{$\begin{array}{c}\mathrm{Y} \\
\text { mín }\end{array}$} & \multirow{2}{*}{$\begin{array}{l}\text { Média } \\
\text { adotada }\end{array}$} \\
\hline & & & & 1 & 2 & 3 & & & & & & & & \\
\hline $\mathrm{LA}^{\prime}$ & 7 & 0 & 40 & 11 & 11 & 12 & 11 & 0,09 & 1,147 & 0,688 & 1,15 & 12 & 11 & 11 \\
\hline $\mathrm{LA}^{\prime}$ & 7 & 5 & 40 & 23 & 23 & 23 & 23 & 0,02 & 0,801 & 1,121 & 1,15 & 23 & 23 & 23 \\
\hline LA' $^{\prime}$ & 7 & 10 & 40 & 29 & 29 & 29 & 29 & 0,06 & 0,968 & 1,029 & 1,15 & 29 & 29 & 29 \\
\hline
\end{tabular}

LA' - Ensaio Realizado com Solo Laterítico Arenoso sem Imersão

- Outliers 
Tabela A12 - Apresentação dos resultados do ensaio triaxial cíclico

\section{Solo Argiloso Laterítico}

\begin{tabular}{|c|c|c|c|c|c|c|c|c|}
\hline \multirow{3}{*}{ Seqüência } & \multicolumn{4}{|c|}{ Tensões } & \multirow{2}{*}{\multicolumn{4}{|c|}{$\begin{array}{l}\text { Módulo de Resiliência } \\
\text { Porcentagens de RESÍDUO-CAL }\end{array}$}} \\
\hline & \multirow{2}{*}{$\begin{array}{c}\sigma_{3} \\
(\mathrm{kPa})\end{array}$} & \multirow{2}{*}{$\begin{array}{c}\sigma_{1} \\
(\mathrm{kPa})\end{array}$} & \multirow{2}{*}{$\begin{array}{c}\sigma_{\mathrm{d}} \\
(\mathrm{kPa})\end{array}$} & \multirow{2}{*}{$\begin{array}{r}\sigma_{\text {cont }} \\
(\mathrm{kPa})\end{array}$} & & & & \\
\hline & & & & & 00-05 & $00-10$ & $40-05$ & $40-10$ \\
\hline 1 & & 24,3 & 22,2 & 2,1 & 692,2 & 1979,0 & 467,4 & 1057,0 \\
\hline 2 & 20,7 & 47,7 & 43,6 & 4,1 & 540,2 & 4411,4 & 347,9 & 1362,7 \\
\hline 3 & & 74,3 & 68,1 & 6,2 & 438,4 & 5125,7 & 323,0 & 952,4 \\
\hline 4 & & 41,8 & 38,3 & 3,5 & 583,6 & 3997,3 & 378,1 & 1450,7 \\
\hline 5 & 34,5 & 82,1 & 75,2 & 6,9 & 449,8 & 4069,7 & 335,3 & 997,9 \\
\hline 6 & & 125,8 & 115,5 & 10,3 & 401,8 & 1859,2 & 304,1 & 800,5 \\
\hline 7 & & 62,5 & 57,2 & 5,3 & 503,3 & 4851,9 & 370,3 & 1339,6 \\
\hline 8 & 52,5 & 126,3 & 115,8 & 10,5 & 439,2 & 4578,9 & 329,6 & 871,2 \\
\hline 9 & & 188,8 & 173,0 & 15,8 & 427,3 & 1712,2 & 323,0 & 802,4 \\
\hline 10 & & 83,3 & 76,4 & 6,9 & 498,1 & 2918,4 & 380,6 & 959,2 \\
\hline 11 & 68,9 & 165,3 & 151,5 & 13,8 & 463,8 & 1799,0 & 343,2 & 873,6 \\
\hline 12 & & 243,2 & 222,5 & 20,7 & 447,7 & 1671,7 & 329,3 & 800,5 \\
\hline 13 & & 83,6 & 76,7 & 6,9 & 574,9 & 2455,0 & 417,7 & 1131,0 \\
\hline 14 & 103,4 & 128,5 & 118,2 & 10,3 & 537,6 & 2019,5 & 393,4 & 925,8 \\
\hline 15 & & 251,9 & 231,2 & 20,7 & 506,3 & 1680,9 & 356,4 & 822,1 \\
\hline 16 & & 128,7 & 118,4 & 10,3 & 616,8 & 2188,1 & 425,4 & 952,2 \\
\hline 17 & 137,9 & 168,7 & 154,9 & 13,8 & 616,0 & 1873,0 & 416,2 & 898,1 \\
\hline 18 & & 304,7 & 277,1 & 27,6 & 482,9 & 1394,9 & 316,0 & 672,4 \\
\hline
\end{tabular}

\section{Solo Argiloso Não-Laterítico}

\begin{tabular}{|c|c|c|c|c|c|c|c|c|}
\hline \multirow{3}{*}{ Seqüência } & \multicolumn{4}{|c|}{ Tensões } & \multirow{2}{*}{\multicolumn{4}{|c|}{$\begin{array}{l}\text { Módulo de Resiliência } \\
\text { Porcentagem de RESíDUO-CAL }\end{array}$}} \\
\hline & \multirow{2}{*}{$\begin{array}{c}\sigma_{3} \\
(\mathrm{kPa})\end{array}$} & \multirow{2}{*}{$\begin{array}{c}\sigma_{1} \\
(\mathrm{kPa})\end{array}$} & \multirow{2}{*}{$\begin{array}{c}\sigma_{\mathrm{d}} \\
(\mathrm{kPa})\end{array}$} & \multirow{2}{*}{$\begin{array}{r}\sigma_{\mathrm{cont}} \\
(\mathrm{kPa}) \\
\end{array}$} & & & & \\
\hline & & & & & 00-05 & $00-10$ & 40-05 & $40-10$ \\
\hline 1 & & 24,3 & 22,2 & 2,1 & 560,6 & 1016,6 & 516,3 & 1558,8 \\
\hline 2 & 20,7 & 47,7 & 43,6 & 4,1 & 366,0 & 1818,9 & 468,5 & 1213,8 \\
\hline 3 & & 74,3 & 68,1 & 6,2 & 468,1 & 4657,4 & 419,8 & 1203,6 \\
\hline 4 & & 41,8 & 38,3 & 3,5 & 327,1 & 1524,9 & 462,6 & 1182,2 \\
\hline 5 & 34,5 & 82,1 & 75,2 & 6,9 & 435,7 & 2715,6 & 428,4 & 1256,6 \\
\hline 6 & & 125,8 & 115,5 & 10,3 & 366,5 & 2841,5 & 399,7 & 1304,3 \\
\hline 7 & & 62,5 & 57,2 & 5,3 & 433,5 & 4146,8 & 446,1 & 1392,0 \\
\hline 8 & 52,5 & 126,3 & 115,8 & 10,5 & 376,8 & 2955,5 & 407,2 & 1371,5 \\
\hline 9 & & 188,8 & 173,0 & 15,8 & 354,1 & 3147,5 & 395,6 & 1359,4 \\
\hline 10 & & 83,3 & 76,4 & 6,9 & 423,8 & 2740,0 & 418,8 & 1353,3 \\
\hline 11 & 68,9 & 165,3 & 151,5 & 13,8 & 382,0 & 2855,1 & 410,8 & 1385,4 \\
\hline 12 & & 243,2 & 222,5 & 20,7 & 350,7 & 2917,7 & 386,8 & 1361,1 \\
\hline 13 & & 83,6 & 76,7 & 6,9 & 460,3 & 4902,7 & 436,1 & 1324,5 \\
\hline 14 & 103,4 & 128,5 & 118,2 & 10,3 & 408,9 & 3352,1 & 422,7 & 1335,9 \\
\hline 15 & & 251,9 & 231,2 & 20,7 & 365,1 & 3056,0 & 389,2 & 1370,8 \\
\hline 16 & & 128,7 & 118,4 & 10,3 & 433,3 & 3171,3 & 442,7 & 1396,7 \\
\hline 17 & 137,9 & 168,7 & 154,9 & 13,8 & 423,3 & 3026,9 & 437,6 & 1398,9 \\
\hline 18 & & 304,7 & 277,1 & 27,6 & 442,2 & 2556,8 & 331,9 & 1142,6 \\
\hline
\end{tabular}


- ANEXO B -

ANÁLISE DE VARIÂNCIA 


\section{Experimento fatorial para o ensaio de resistência à compressão simples} para 7 dias de cura.

Fatores

\begin{tabular}{|c|c|c|c|c|c|}
\hline \multirow[b]{2}{*}{ A } & \multirow[b]{2}{*}{ Tipo de solo } & \multirow{2}{*}{$\begin{array}{c}\text { Níveis } \\
2\end{array}$} & \multicolumn{2}{|c|}{ Descrição } & \multirow[t]{2}{*}{ Repetições $r=$} \\
\hline & & & 0 & LG' & \\
\hline & & & 1 & NG' & \\
\hline \multirow[t]{2}{*}{ B } & Teor de resíduo & 2 & 0 & $0 \%$ & \\
\hline & & & 1 & $40 \%$ & \\
\hline \multirow[t]{4}{*}{ C } & Teor de cal & 3 & 0 & $0 \%$ & \\
\hline & & & 1 & $5 \%$ & \\
\hline & & & 2 & $10 \%$ & \\
\hline & $m=$ & 12 & & & \\
\hline
\end{tabular}

\begin{tabular}{|c|c|c|c|c|c|c|c|c|c|c|}
\hline \multirow{3}{*}{$\begin{array}{l}\text { Cond. } \\
\text { Exp. } \\
\text { (j) }\end{array}$} & \multirow{3}{*}{$\begin{array}{c}\text { A } \\
\begin{array}{c}\text { Tipo de } \\
\text { solo }\end{array}\end{array}$} & \multirow{3}{*}{$\begin{array}{c}\text { B } \\
\text { Teor de } \\
\text { resíduo }\end{array}$} & \multirow{3}{*}{$\begin{array}{c}\text { C } \\
\begin{array}{c}\text { Teor } \\
\text { de cal }\end{array}\end{array}$} & \multirow{2}{*}{\multicolumn{3}{|c|}{$\frac{\text { RCS }}{\text { Repetição }}$}} & \multirow{3}{*}{$\begin{array}{c}\text { Totais } \\
\text { parciais } \\
\mathrm{T}(\mathrm{c})\end{array}$} & \multirow{3}{*}{$r$} & \multirow{3}{*}{$\mathrm{T}(\mathrm{c}) / \mathrm{r}$} & \multirow{3}{*}{$\sum_{k=1}^{r} Y_{K}^{2}$} \\
\hline & & & & & & & & & & \\
\hline & & & & Y1 & Y2 & Y3 & & & & \\
\hline 1 & 0 & 0 & 0 & 245 & 261 & 271 & 777 & 3 & 259 & 201805 \\
\hline 2 & 1 & 0 & 0 & 330 & 339 & 339 & 1008 & 3 & 336 & 339069 \\
\hline 3 & 0 & 1 & 0 & 204 & 216 & 221 & 641 & 3 & 214 & 137156 \\
\hline 4 & 1 & 1 & 0 & 159 & 162 & 162 & 483 & 3 & 161 & 77609 \\
\hline 5 & 0 & 0 & 1 & 785 & 793 & 806 & 2383 & 3 & 794 & 1893281 \\
\hline 6 & 1 & 0 & 1 & 624 & 647 & 676 & 1948 & 3 & 649 & 1265760 \\
\hline 7 & 0 & 1 & 1 & 422 & 427 & 443 & 1292 & 3 & 431 & 556565 \\
\hline 8 & 1 & 1 & 1 & 391 & 406 & 450 & 1247 & 3 & 416 & 520168 \\
\hline 9 & 0 & 0 & 2 & 1125 & 1133 & 1149 & 3407 & 3 & 1136 & 3869417 \\
\hline 10 & 1 & 0 & 2 & 1495 & 1566 & 1581 & 4641 & 3 & 1547 & 7184842 \\
\hline 11 & 0 & 1 & 2 & 687 & 692 & 714 & 2092 & 3 & 697 & 1459644 \\
\hline 12 & 1 & 1 & 2 & 764 & 770 & 788 & 2322 & 3 & 774 & 1797259 \\
\hline & & & & & & Total & 22.241 & 36 & 7.414 & 19.302 .575 \\
\hline
\end{tabular}

$$
C=\frac{\left(\sum_{i=1}^{j} T_{i}\right)^{2}}{\sum r}=66.724 \quad S Q_{\text {total }}=\sum_{i=1}^{j} \sum_{k=1}^{r} Y_{k}^{2}-C=5.561 .443
$$




\begin{tabular}{lcc|c} 
& A0 & A1 & \\
B0 & 6567 & 7597 & 14165 \\
B1 & 4025 & 4051 & 8077 \\
\cline { 2 - 3 } & 10593 & 11649 & 22241 \\
& & & \\
& A0 & A1 & \\
C0 & 1419 & 1491 & 2910 \\
C1 & 3675 & 3195 & 6870 \\
C2 & 5499 & 6963 & 12462 \\
\cline { 2 - 3 } & 10593 & 11649 & 22241 \\
& & & \\
& B0 & B1 & \\
C0 & 1786 & 1124 & 2910 \\
C1 & 4331 & 2539 & 6870 \\
C2 & 8048 & 4414 & 12462 \\
\cline { 2 - 3 } & 14165 & 8077 & 22241
\end{tabular}

Soma de quadrados

\begin{tabular}{|c|c|}
\hline$A O B$ & 1.088 .636 \\
\hline A & 30.976 \\
\hline B & 1.029 .657 \\
\hline$A B$ & 28.004 \\
\hline$A \in G$ & 4.037 .666 \\
\hline A & 30.976 \\
\hline C & 3.839 .415 \\
\hline$A C$ & 167.274 \\
\hline$B \in C$ & 5.244 .144 \\
\hline B & 1.029 .657 \\
\hline C & 3.839 .415 \\
\hline$B C$ & 375.072 \\
\hline$A e B e G$ & 5.551 .905 \\
\hline $\mathrm{ABC}$ & 81.507 \\
\hline
\end{tabular}

Análise do planejamento fatorial completo com 3 fatores

\begin{tabular}{|c|c|c|c|c|c|c|c|c|}
\hline \multirow{2}{*}{$\begin{array}{l}\text { Fonte } \\
\text { de Var. }\end{array}$} & \multirow{2}{*}{$\begin{array}{l}\text { Soma de } \\
\text { quadrados } \\
\text { (SQ) }\end{array}$} & \multirow{2}{*}{$\begin{array}{c}\text { Graus } \\
\text { de lib. } \\
\text { (GL) }\end{array}$} & \multirow{2}{*}{$\begin{array}{c}\text { Quad } \\
\text { médio } \\
Q M=S Q / G L\end{array}$} & \multirow{2}{*}{$F_{0}$} & \multirow{2}{*}{$F_{0,05}$} & \multirow{2}{*}{$F_{0,01}$} & \multicolumn{2}{|c|}{$p$} \\
\hline & & & & & & & $F_{0}>F_{0,05}$ & $\mathrm{~F}_{0}>\mathrm{F}_{0,01}$ \\
\hline A & 30.976 & 1 & 30.976 & 8,85 & 4,13 & 7,44 & Sim & Sim \\
\hline B & 1.029 .657 & 1 & 1.029 .657 & 294,04 & 4,13 & 7,44 & Sim & Sim \\
\hline C & 3.839 .415 & 2 & 1.919 .708 & 548,22 & 3,28 & 5,29 & Sim & Sim \\
\hline$A B$ & 28.004 & 1 & 28.004 & 8,00 & 4,13 & 7,44 & Sim & Sim \\
\hline AC & 167.274 & 2 & 83.637 & 23,88 & 3,28 & 5,29 & Sim & Sim \\
\hline $\mathrm{BC}$ & 375.072 & 2 & 187.536 & 53,56 & 3,28 & 5,29 & Sim & Sim \\
\hline ERRO & 91.045 & 26 & 3.502 & & & & & \\
\hline TOTAL & 5.561 .443 & 35 & 158.898 & & & & & \\
\hline
\end{tabular}


Experimento fatorial para o ensaio de resistência à compressão diametral para 7 dias de cura.

Fatores

\begin{tabular}{|c|c|c|c|c|c|}
\hline \multirow[b]{2}{*}{ A } & \multirow[b]{2}{*}{ Tipo de solo } & \multirow{2}{*}{$\begin{array}{c}\text { Níveis } \\
2\end{array}$} & \multicolumn{2}{|c|}{ Descrição } & \multirow[t]{2}{*}{ Repetições $r=$} \\
\hline & & & 0 & LG' & \\
\hline & & & 1 & NG' & \\
\hline \multirow[t]{2}{*}{$B$} & Teor de resíduo & 2 & 0 & $0 \%$ & \\
\hline & & & 1 & $40 \%$ & \\
\hline \multirow[t]{4}{*}{ C } & Teor de cal & 3 & 0 & $0 \%$ & \\
\hline & & & 1 & $5 \%$ & \\
\hline & & & 2 & $10 \%$ & \\
\hline & $\mathrm{m}=$ & 12 & & & \\
\hline
\end{tabular}

\begin{tabular}{|c|c|c|c|c|c|c|c|c|c|c|}
\hline \multirow{3}{*}{$\begin{array}{l}\text { Cond. } \\
\text { Exp. } \\
\text { (j) }\end{array}$} & \multirow{3}{*}{$\begin{array}{c}\text { A } \\
\begin{array}{c}\text { Tipo de } \\
\text { solo }\end{array}\end{array}$} & \multirow{3}{*}{ 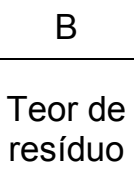 } & \multirow{3}{*}{$\begin{array}{c}\text { C } \\
\text { Teor } \\
\text { de cal }\end{array}$} & \multicolumn{3}{|c|}{ RCS } & \multirow{3}{*}{$\begin{array}{c}\text { Totais } \\
\text { parciais } \\
\text { T(c) }\end{array}$} & \multirow{3}{*}{$r$} & \multirow{3}{*}{$\mathrm{T}(\mathrm{c}) / \mathrm{r}$} & \multirow{3}{*}{$\sum_{k=1}^{r} Y_{K}^{2}$} \\
\hline & & & & \multicolumn{3}{|c|}{ Repetição } & & & & \\
\hline & & & & Y1 & Y2 & Y3 & & & & \\
\hline 1 & 0 & 0 & 0 & 23 & 23 & 29 & 75 & 3 & 25 & 1891 \\
\hline 2 & 1 & 0 & 0 & 29 & 34 & 34 & 97 & 3 & 32 & 3157 \\
\hline 3 & 0 & 1 & 0 & 23 & 26 & 26 & 75 & 3 & 25 & 1874 \\
\hline 4 & 1 & 1 & 0 & 11 & 11 & 11 & 34 & 3 & 11 & 389 \\
\hline 5 & 0 & 0 & 1 & 87 & 92 & 92 & 271 & 3 & 90 & 24501 \\
\hline 6 & 1 & 0 & 1 & 74 & 80 & 86 & 240 & 3 & 80 & 19230 \\
\hline 7 & 0 & 1 & 1 & 34 & 34 & 40 & 109 & 3 & 36 & 3961 \\
\hline 8 & 1 & 1 & 1 & 57 & 62 & 68 & 187 & 3 & 62 & 11672 \\
\hline 9 & 0 & 0 & 2 & 139 & 144 & 144 & 427 & 3 & 142 & 60827 \\
\hline 10 & 1 & 0 & 2 & 172 & 177 & 190 & 539 & 3 & 180 & 96952 \\
\hline 11 & 0 & 1 & 2 & 115 & 115 & 120 & 351 & 3 & 117 & 41000 \\
\hline \multirow[t]{2}{*}{12} & 1 & 1 & 2 & 113 & 119 & 125 & 357 & 3 & 119 & 42461 \\
\hline & & & & & & Total & 2.760 & 36 & 920 & 307.916 \\
\hline
\end{tabular}

$$
C=\frac{\left(\sum_{i=1}^{j} T_{i}\right)^{2}}{\sum r}=8.281 \quad S Q_{\text {total }}=\sum_{i=1}^{j} \sum_{k=1}^{r} Y_{k}^{2}-C=96.279
$$




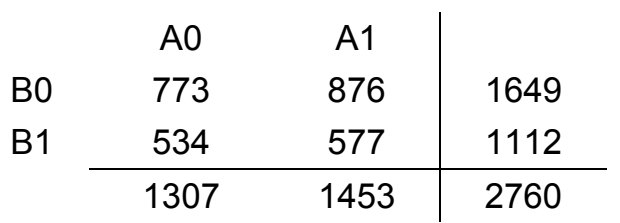

\begin{tabular}{ccc|c} 
& A0 & A1 & \\
C0 & 150 & 131 & 281 \\
C1 & 380 & 426 & 806 \\
C2 & 778 & 895 & 1673 \\
\cline { 2 - 4 } & 1307 & 1453 & 2760
\end{tabular}

\begin{tabular}{ccc|c} 
& B0 & B1 & \\
C0 & 172 & 109 & 281 \\
C1 & 511 & 295 & 806 \\
C2 & 966 & 707 & 1673 \\
\cline { 2 - 4 } & 1649 & 1112 & 2760
\end{tabular}

Soma de quadrados

\begin{tabular}{|c|c|}
\hline$A \oplus B$ & 8.700 \\
\hline A & 590 \\
\hline B & 8.012 \\
\hline$A B$ & 98 \\
\hline$A \in G$ & 83.761 \\
\hline A & 590 \\
\hline C & 82.395 \\
\hline$A C$ & 776 \\
\hline$B \otimes C$ & 92.170 \\
\hline $\mathrm{B}$ & 8.012 \\
\hline C & 82.395 \\
\hline $\mathrm{BC}$ & 1.762 \\
\hline AeBeC & 95.788 \\
\hline$A B C$ & 2.155 \\
\hline
\end{tabular}

Análise do planejamento fatorial completo com 3 fatores

\begin{tabular}{|c|c|c|c|c|c|c|c|c|}
\hline \multirow{2}{*}{$\begin{array}{l}\text { Fonte } \\
\text { de Var. }\end{array}$} & \multirow{2}{*}{$\begin{array}{l}\text { Soma de } \\
\text { quadrados } \\
\text { (SQ) }\end{array}$} & \multirow{2}{*}{$\begin{array}{l}\text { Graus } \\
\text { de lib. } \\
\text { (GL) }\end{array}$} & \multirow{2}{*}{$\begin{array}{c}\text { Quad } \\
\text { médio } \\
Q M=S Q / G L\end{array}$} & \multirow{2}{*}{$\mathrm{F}_{0}$} & \multirow{2}{*}{$F_{0,05}$} & \multirow{2}{*}{$F_{0,01}$} & \multicolumn{2}{|c|}{$p$} \\
\hline & & & & & & & $\mathrm{F}_{0}>\mathrm{F}_{0,05}$ & $\mathrm{~F}_{0}>\mathrm{F}_{0,01}$ \\
\hline$A$ & 590 & 1 & 590 & 5,80 & 4,13 & 7,44 & Sim & Não \\
\hline B & 8.012 & 1 & 8.012 & 78,74 & 4,13 & 7,44 & Sim & Sim \\
\hline C & 82.395 & 2 & 41.198 & 404,87 & 3,28 & 5,29 & Sim & Sim \\
\hline$A B$ & 98 & 1 & 98 & 0,96 & 4,13 & 7,44 & Não & Não \\
\hline$A C$ & 776 & 2 & 388 & 3,81 & 3,28 & 5,29 & Sim & Não \\
\hline$B C$ & 1.762 & 2 & 881 & 8,66 & 3,28 & 5,29 & Sim & Sim \\
\hline ERRO & 2.646 & 26 & 102 & & & & & \\
\hline TOTAL & 96.279 & 35 & 2.751 & & & & & \\
\hline
\end{tabular}




\section{Experimento fatorial do módulo tangente inicial para 7 dias de cura.}

Fatores

\begin{tabular}{|c|c|c|c|c|c|}
\hline & & Níveis & & & Repetições $r=$ \\
\hline \multirow[t]{2}{*}{ A } & Tipo de solo & 2 & 0 & LG' & \\
\hline & & & 1 & NG' & \\
\hline \multirow[t]{2}{*}{$B$} & Teor de resíduo & 2 & 0 & $0 \%$ & \\
\hline & & & 1 & $40 \%$ & \\
\hline \multirow[t]{4}{*}{ C } & Teor de cal & 3 & 0 & $0 \%$ & \\
\hline & & & 1 & $5 \%$ & \\
\hline & & & 2 & $10 \%$ & \\
\hline & $\mathrm{m}=$ & 12 & & & \\
\hline
\end{tabular}

\begin{tabular}{|c|c|c|c|c|c|c|c|c|c|c|}
\hline \multirow{3}{*}{$\begin{array}{l}\text { Cond. } \\
\text { Exp. } \\
\text { (j) }\end{array}$} & \multirow{3}{*}{$\begin{array}{c}\text { A } \\
\begin{array}{c}\text { Tipo de } \\
\text { solo }\end{array}\end{array}$} & \multirow{3}{*}{ 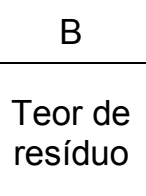 } & \multirow{3}{*}{ 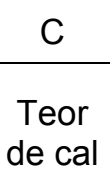 } & \multicolumn{3}{|c|}{ RCS } & \multirow{3}{*}{$\begin{array}{c}\text { Totais } \\
\text { parciais } \\
\text { T(c) }\end{array}$} & \multirow{3}{*}{$r$} & \multirow{3}{*}{$\mathrm{T}(\mathrm{c}) / \mathrm{r}$} & \multirow{3}{*}{$\sum_{k=1}^{r} \mathrm{Y}_{\mathrm{K}}^{2}$} \\
\hline & & & & \multicolumn{3}{|c|}{ Repetição } & & & & \\
\hline & & & & Y1 & Y2 & Y3 & & & & \\
\hline 1 & 0 & 0 & 0 & 63 & 70 & 75 & 208 & 3 & 69 & 14494 \\
\hline 2 & 1 & 0 & 0 & 67 & 73 & 74 & 214 & 3 & 71 & 15294 \\
\hline 3 & 0 & 1 & 0 & 22 & 27 & 29 & 78 & 3 & 26 & 2054 \\
\hline 4 & 1 & 1 & 0 & 10 & 11 & 14 & 35 & 3 & 12 & 417 \\
\hline 5 & 0 & 0 & 1 & 469 & 475 & 498 & 1442 & 3 & 481 & 693590 \\
\hline 6 & 1 & 0 & 1 & 276 & 293 & 357 & 926 & 3 & 309 & 289474 \\
\hline 7 & 0 & 1 & 1 & 59 & 60 & 62 & 181 & 3 & 60 & 10925 \\
\hline 8 & 1 & 1 & 1 & 81 & 90 & 99 & 270 & 3 & 90 & 24462 \\
\hline 9 & 0 & 0 & 2 & 848 & 958 & 960 & 2766 & 3 & 922 & 2558468 \\
\hline 10 & 1 & 0 & 2 & 1234 & 1375 & 1420 & 4029 & 3 & 1343 & 5429781 \\
\hline 11 & 0 & 1 & 2 & 357 & 390 & 420 & 1167 & 3 & 389 & 455949 \\
\hline \multirow[t]{2}{*}{12} & 1 & 1 & 2 & 227 & 252 & 259 & 738 & 3 & 246 & 182114 \\
\hline & & & & & & Total & 12.054 & 36 & 4.018 & 9.677 .022 \\
\hline
\end{tabular}

$$
C=\frac{\left(\sum_{i=1}^{j} T_{i}\right)^{2}}{\sum r}=36.162 \quad S Q_{\text {total }}=\sum_{i=1}^{j} \sum_{k=1}^{r} Y_{k}^{2}-C=5.640 .941
$$




\begin{tabular}{ccc|c} 
& A0 & A1 & \\
B0 & 4416 & 5169 & 9585 \\
B1 & 1426 & 1043 & 2469 \\
\cline { 2 - 4 } & 5842 & 6212 & 12054
\end{tabular}

\begin{tabular}{ccc|c} 
& A0 & A1 & \\
C0 & 286 & 249 & 535 \\
C1 & 1623 & 1196 & 2819 \\
C2 & 3933 & 4767 & 8700 \\
\cline { 2 - 4 } & 5842 & 6212 & 12054
\end{tabular}

\begin{tabular}{ccc|c} 
& B0 & B1 & \\
C0 & 422 & 113 & 535 \\
C1 & 2368 & 451 & 2819 \\
C2 & 6795 & 1905 & 8700 \\
\cline { 2 - 4 } & 9585 & 2469 & 12054
\end{tabular}

\section{Soma de quadrados}

\begin{tabular}{|c|c|}
\hline$A \in B$ & 1.446 .246 \\
\hline A & 3.803 \\
\hline B & 1.406 .596 \\
\hline$A B$ & 35.847 \\
\hline$A \in C$ & 3.030 .772 \\
\hline A & 3.803 \\
\hline C & 2.957.501 \\
\hline$A C$ & 69.468 \\
\hline$B \in C$ & 5.264 .374 \\
\hline B & 1.406 .596 \\
\hline C & 2.957 .501 \\
\hline BC & 900.277 \\
\hline$A \in B e C$ & 5.606 .919 \\
\hline$A B C$ & 233.427 \\
\hline
\end{tabular}

Análise do planejamento fatorial completo com 3 fatores

\begin{tabular}{|c|c|c|c|c|c|c|c|c|}
\hline \multirow{2}{*}{$\begin{array}{l}\text { Fonte } \\
\text { de Var. }\end{array}$} & \multirow{2}{*}{$\begin{array}{l}\text { Soma de } \\
\text { quadrados } \\
\text { (SQ) }\end{array}$} & \multirow{2}{*}{$\begin{array}{l}\text { Graus } \\
\text { de lib. } \\
\text { (GL) }\end{array}$} & \multirow{2}{*}{$\begin{array}{c}\text { Quad } \\
\text { médio } \\
\text { QM=SQ/GL }\end{array}$} & \multirow{2}{*}{$\mathrm{F}_{0}$} & \multirow{2}{*}{$F_{0,05}$} & \multirow{2}{*}{$\mathrm{F}_{0,01}$} & \multicolumn{2}{|c|}{$\mathrm{p}$} \\
\hline & & & & & & & $\mathrm{F}_{0}>\mathrm{F}_{0,05}$ & $\mathrm{~F}_{0}>\mathrm{F}_{0,01}$ \\
\hline$A$ & 3.803 & 1 & 3.803 & 0,37 & 4,13 & 7,44 & Não & Não \\
\hline B & 1.406 .596 & 1 & 1.406 .596 & 136,74 & 4,13 & 7,44 & Sim & Sim \\
\hline C & 2.957 .501 & 2 & 1.478 .751 & 143,76 & 3,28 & 5,29 & Sim & Sim \\
\hline$A B$ & 35.847 & 1 & 35.847 & 3,48 & 4,13 & 7,44 & Não & Não \\
\hline$A C$ & 69.468 & 2 & 34.734 & 3,38 & 3,28 & 5,29 & Sim & Não \\
\hline $\mathrm{BC}$ & 900.277 & 2 & 450.138 & 43,76 & 3,28 & 5,29 & Sim & Sim \\
\hline ERRO & 267.449 & 26 & 10.287 & & & & & \\
\hline TOTAL & 5.640 .941 & 35 & 161.170 & & & & & \\
\hline
\end{tabular}


Experimento fatorial para o ensaio triaxial cíclico para 7 dias de cura.

Fatores

\begin{tabular}{|c|c|c|c|c|c|}
\hline & & Níveis & & & Repetições $r=$ \\
\hline \multirow[t]{2}{*}{$A$} & Tipo de solo & 2 & 0 & LG' & \\
\hline & & & 1 & NG' & \\
\hline \multirow[t]{2}{*}{ B } & Teor de resíduo & 2 & 0 & $0 \%$ & \\
\hline & & & 1 & $40 \%$ & \\
\hline \multirow[t]{3}{*}{ C } & Teor de cal & 2 & 0 & $5 \%$ & \\
\hline & & & 1 & $10 \%$ & \\
\hline & $m=$ & 8 & & & \\
\hline
\end{tabular}

\begin{tabular}{|c|c|c|c|c|c|c|c|c|c|c|}
\hline \multirow{3}{*}{$\begin{array}{l}\text { Cond. } \\
\text { Exp. } \\
\text { (j) }\end{array}$} & \multirow{3}{*}{$\begin{array}{c}\text { A } \\
\begin{array}{c}\text { Tipo de } \\
\text { solo }\end{array}\end{array}$} & \multirow{3}{*}{$\begin{array}{c}\text { B } \\
\text { Teor de } \\
\text { resíduo }\end{array}$} & \multirow{3}{*}{ 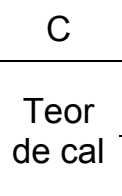 } & \multicolumn{3}{|c|}{ RCS } & \multirow{3}{*}{$\begin{array}{c}\text { Totais } \\
\text { parciais } \\
\text { T(c) }\end{array}$} & \multirow{3}{*}{$r$} & \multirow{3}{*}{$\mathrm{T}(\mathrm{c}) / \mathrm{r}$} & \multirow{3}{*}{$\sum_{k=1}^{r} \mathrm{Y}_{K}^{2}$} \\
\hline & & & & \multicolumn{3}{|c|}{ Repetição } & & & & \\
\hline & & & & Y1 & Y2 & Y3 & & & & \\
\hline 1 & 0 & 0 & 0 & 375 & - & - & 375 & 1 & 375 & 140625 \\
\hline 2 & 1 & 0 & 0 & 339 & - & - & 339 & 1 & 339 & 114921 \\
\hline 3 & 0 & 1 & 0 & 263 & - & - & 263 & 1 & 263 & 69169 \\
\hline 4 & 1 & 1 & 0 & 375 & - & - & 375 & 1 & 375 & 140625 \\
\hline 5 & 0 & 0 & 1 & 1762 & - & - & 1762 & 1 & 1762 & 3104644 \\
\hline 6 & 1 & 0 & 1 & 3129 & - & - & 3129 & 1 & 3129 & 9790641 \\
\hline 7 & 0 & 1 & 1 & 686 & - & - & 686 & 1 & 686 & 470596 \\
\hline \multirow[t]{2}{*}{8} & 1 & 1 & 1 & 1389 & - & - & 1389 & 1 & 1389 & 1929321 \\
\hline & & & & & & Total & 8.318 & 8 & 8.318 & 15.760 .542 \\
\hline
\end{tabular}

$$
C=\frac{\left(\sum_{i=1}^{j} T_{i}\right)^{2}}{\sum r}=8.318
$$$$
S Q_{\text {total }}=\sum_{i=1}^{j} \sum_{k=1}^{r} Y_{k}^{2}-C=7.111 .902
$$ 


\begin{tabular}{lcc|c} 
& A0 & A1 & \\
B0 & 2137 & 3468 & 5605 \\
B1 & 949 & 1764 & 2713 \\
\cline { 2 - 3 } & 3086 & 5232 & 8318 \\
& & \multicolumn{2}{|c}{} \\
& A0 & A1 & \\
C0 & 638 & 714 & 1352 \\
C1 & 2448 & 4518 & 6966 \\
\hline & 3086 & 5232 & 8318 \\
& & & \\
& B0 & B1 & \\
C0 & 714 & 638 & 1352 \\
C1 & 4891 & 2075 & 6966 \\
\cline { 2 - 4 } & 5605 & 2713 & 8318
\end{tabular}

Soma de quadrados

\begin{tabular}{|c|c|}
\hline$A \in B$ & 1.654 .405 \\
\hline A & 575.665 \\
\hline B & 1.045 .458 \\
\hline$A B$ & 33.282 \\
\hline$A \in C$ & 5.012 .294 \\
\hline A & 575.665 \\
\hline C & 3.939 .625 \\
\hline$A C$ & 497.005 \\
\hline$B \in G$ & 5.923 .533 \\
\hline B & 1.045 .458 \\
\hline C & 3.939 .625 \\
\hline $\mathrm{BC}$ & 938.450 \\
\hline $\begin{array}{c}A \text { e } B \text { e } C \\
A B C\end{array}$ & $\begin{array}{c}7.111 .902 \\
82.418\end{array}$ \\
\hline
\end{tabular}

Análise do planejamento fatorial completo com 3 fatores

\begin{tabular}{|c|c|c|c|c|c|c|c|c|}
\hline \multirow{2}{*}{$\begin{array}{l}\text { Fonte } \\
\text { de Var. }\end{array}$} & \multirow{2}{*}{$\begin{array}{l}\text { Soma de } \\
\text { quadrados } \\
\text { (SQ) }\end{array}$} & \multirow{2}{*}{$\begin{array}{l}\text { Graus } \\
\text { de lib. } \\
\text { (GL) }\end{array}$} & \multirow{2}{*}{$\begin{array}{c}\text { Quad } \\
\text { médio } \\
\text { QM=SQ/GL }\end{array}$} & \multirow{2}{*}{$F_{0}$} & \multirow{2}{*}{$F_{0,05}$} & \multirow{2}{*}{$F_{0,01}$} & \multicolumn{2}{|c|}{$p$} \\
\hline & & & & & & & $\mathrm{F}_{0}>\mathrm{F}_{0,05}$ & $F_{0}>F_{0,01}$ \\
\hline$A$ & 575.665 & 1 & 575.665 & 6,98 & 5,99 & 13,75 & Sim & Não \\
\hline B & 1.045 .458 & 1 & 1.045 .458 & 12,68 & 5,99 & 13,75 & Sim & Não \\
\hline C & 3.939 .625 & 1 & 3.939 .625 & 47,80 & 5,99 & 13,75 & Sim & Sim \\
\hline$A B$ & 33.282 & 1 & 33.282 & 0,40 & 5,99 & 13,75 & Não & Não \\
\hline$A C$ & 497.005 & 1 & 497.005 & 6,03 & 5,99 & 13,75 & Sim & Não \\
\hline $\mathrm{BC}$ & 938.450 & 1 & 938.450 & 11,39 & 5,99 & 13,75 & Sim & Não \\
\hline ERRO & 82.418 & 1 & 82.418 & & & & & \\
\hline TOTAL & 7.111 .902 & 7 & 1.015 .986 & & & & & \\
\hline
\end{tabular}




\section{Experimento fatorial para o ensaio de resistência à compressão simples para o teor de $10 \%$ de cal.}

\section{Fatores}

\begin{tabular}{|c|c|c|c|c|c|}
\hline & & Níveis & Descripção & & Repetições $r=3$ \\
\hline \multirow[t]{2}{*}{$A$} & Tipo de solo & 2 & 0 & LG' & \\
\hline & & & 1 & NG' & \\
\hline \multirow[t]{2}{*}{ B } & Teor de resíduo & 2 & 0 & $0 \%$ & \\
\hline & & & 1 & $40 \%$ & \\
\hline \multirow[t]{2}{*}{ C } & Condição de imersão & 2 & 0 & Não imerso & \\
\hline & & & 1 & Imerso & \\
\hline \multirow[t]{6}{*}{ D } & Tempo de cura & 5 & 0 & 0 & \\
\hline & & & 1 & 2 & \\
\hline & & & 2 & 7 & \\
\hline & & & 3 & 28 & \\
\hline & & & 4 & 84 & \\
\hline & $\mathrm{m}=$ & 40 & & & \\
\hline
\end{tabular}

\begin{tabular}{|c|c|c|c|c|c|c|c|c|c|c|c|}
\hline \multirow{3}{*}{$\begin{array}{l}\text { Cond. } \\
\text { Exp. } \\
\text { (j) }\end{array}$} & \multirow{3}{*}{$\begin{array}{c}\text { A } \\
\text { Tipo } \\
\text { de } \\
\text { solo }\end{array}$} & \multirow{3}{*}{$\begin{array}{c}\text { B } \\
\text { Teor } \\
\text { de } \\
\text { resíduo }\end{array}$} & \multirow{3}{*}{$\begin{array}{c}\text { C } \\
\text { Condição } \\
\text { de } \\
\text { imersão }\end{array}$} & \multirow{3}{*}{$\begin{array}{c}\text { D } \\
\begin{array}{c}\text { Tempo } \\
\text { de } \\
\text { cura }\end{array}\end{array}$} & \multirow{2}{*}{\multicolumn{3}{|c|}{$\frac{\text { RCS }}{\text { Repetição }}$}} & \multirow{3}{*}{$\begin{array}{c}\text { Totais } \\
\text { parciais } \\
\mathrm{T}(\mathrm{c})\end{array}$} & \multirow{3}{*}{$r$} & \multirow{3}{*}{$\mathrm{T}(\mathrm{c}) / \mathrm{r}$} & \multirow{3}{*}{$\sum_{\mathrm{k}=1}^{\mathrm{r}} \mathrm{K}^{2}$} \\
\hline & & & & & & & & & & & \\
\hline & & & & & Y1 & Y2 & Y3 & & & & \\
\hline 1 & 0 & 0 & 0 & 0 & 398 & 408 & 415 & 1220 & 3 & 407 & 496290 \\
\hline 2 & 1 & 0 & 0 & 0 & 319 & 328 & 329 & 976 & 3 & 325 & 317696 \\
\hline 3 & 0 & 1 & 0 & 0 & 0 & 0 & 0 & 0 & 3 & 0 & 0 \\
\hline 4 & 1 & 1 & 0 & 0 & 0 & 0 & 0 & 0 & 3 & 0 & 0 \\
\hline 5 & 0 & 0 & 1 & 0 & 0 & 0 & 0 & 0 & 3 & 0 & 0 \\
\hline 6 & 1 & 0 & 1 & 0 & 0 & 0 & 0 & 0 & 3 & 0 & 0 \\
\hline 7 & 0 & 1 & 1 & 0 & 0 & 0 & 0 & 0 & 3 & 0 & 0 \\
\hline 8 & 1 & 1 & 1 & 0 & 0 & 0 & 0 & 0 & 3 & 0 & 0 \\
\hline 9 & 0 & 0 & 0 & 1 & 842 & 864 & 871 & 2577 & 3 & 859 & 2213323 \\
\hline 10 & 1 & 0 & 0 & 1 & 715 & 725 & 789 & 2229 & 3 & 743 & 1659220 \\
\hline 11 & 0 & 1 & 0 & 1 & 464 & 531 & 568 & 1562 & 3 & 521 & 818918 \\
\hline 12 & 1 & 1 & 0 & 1 & 584 & 585 & 658 & 1828 & 3 & 609 & 1117239 \\
\hline 13 & 0 & 0 & 1 & 1 & 436 & 626 & 644 & 1705 & 3 & 568 & 996147 \\
\hline 14 & 1 & 0 & 1 & 1 & 592 & 644 & 650 & 1886 & 3 & 629 & 1188063 \\
\hline 15 & 0 & 1 & 1 & 1 & 245 & 266 & 334 & 845 & 3 & 282 & 242255 \\
\hline 16 & 1 & 1 & 1 & 1 & 422 & 439 & 456 & 1316 & 3 & 439 & 577933 \\
\hline 17 & 0 & 0 & 0 & 2 & 1125 & 1133 & 1149 & 3407 & 3 & 1136 & 3869417 \\
\hline 18 & 1 & 0 & 0 & 2 & 1495 & 1566 & 1581 & 4641 & 3 & 1547 & 7184842 \\
\hline 19 & 0 & 1 & 0 & 2 & 687 & 692 & 714 & 2092 & 3 & 697 & 1459644 \\
\hline 20 & 1 & 1 & 0 & 2 & 764 & 770 & 788 & 2322 & 3 & 774 & 1797259 \\
\hline 21 & 0 & 0 & 1 & 2 & 1017 & 1040 & 1052 & 3109 & 3 & 1036 & 3221585 \\
\hline 22 & 1 & 0 & 1 & 2 & 1325 & 1361 & 1366 & 4053 & 3 & 1351 & 5475241 \\
\hline 23 & 0 & 1 & 1 & 2 & 557 & 559 & 567 & 1683 & 3 & 561 & 944027 \\
\hline 24 & 1 & 1 & 1 & 2 & 473 & 506 & 572 & 1551 & 3 & 517 & 806700 \\
\hline 25 & 0 & 0 & 0 & 3 & 1009 & 1150 & 1345 & 3504 & 3 & 1168 & 4149378 \\
\hline
\end{tabular}




\begin{tabular}{cccccccccccc}
26 & 1 & 0 & 0 & 3 & 2398 & 2419 & 2419 & 7235 & 3 & 2412 & 17448212 \\
27 & 0 & 1 & 0 & 3 & 685 & 713 & 759 & 2156 & 3 & 719 & 1552733 \\
28 & 1 & 1 & 0 & 3 & 1058 & 1125 & 1311 & 3495 & 3 & 1165 & 4105760 \\
29 & 0 & 0 & 1 & 3 & 1067 & 1073 & 1195 & 3335 & 3 & 1112 & 3718784 \\
30 & 1 & 0 & 1 & 3 & 1660 & 1875 & 1929 & 5463 & 3 & 1821 & 9989245 \\
31 & 0 & 1 & 1 & 3 & 578 & 593 & 610 & 1781 & 3 & 594 & 1057477 \\
32 & 1 & 1 & 1 & 3 & 692 & 835 & 875 & 2402 & 3 & 801 & 1940974 \\
33 & 0 & 0 & 0 & 4 & 1159 & 1196 & 1232 & 3586 & 3 & 1195 & 4289617 \\
34 & 1 & 0 & 0 & 4 & 2555 & 2880 & 2982 & 8417 & 3 & 2806 & 23712888 \\
35 & 0 & 1 & 0 & 4 & 741 & 819 & 846 & 2406 & 3 & 802 & 1936092 \\
36 & 1 & 1 & 0 & 4 & 1252 & 1331 & 1375 & 3958 & 3 & 1319 & 5228753 \\
37 & 0 & 0 & 1 & 4 & 823 & 1081 & 1093 & 2997 & 3 & 999 & 3039906 \\
38 & 1 & 0 & 1 & 4 & 2264 & 2306 & 2442 & 7013 & 3 & 2338 & 16412034 \\
39 & 0 & 1 & 1 & 4 & 494 & 604 & 775 & 1874 & 3 & 625 & 1210175 \\
40 & 1 & 1 & 1 & 4 & 1032 & 1175 & 1179 & 3387 & 3 & 1129 & 3837364 \\
\hline
\end{tabular}

$C=\frac{\left(\sum_{i=1}^{j} T_{i}\right)^{2}}{\sum r}=306.027$

$\begin{array}{lllll}\text { Total } & 102.009 & 120 & 34.003 & 138.015 .188\end{array}$

\begin{tabular}{ccc|c} 
& A0 & A1 & \\
B0 & 25440 & 41913 & 67353 \\
B1 & 14399 & 20257 & 34656 \\
\hline & 39839 & 62170 & 102009
\end{tabular}

\begin{tabular}{ccc|c} 
& A0 & A1 & \\
C0 & 22511 & 35100 & 57611 \\
C1 & 17328 & 27070 & 44398 \\
\cline { 2 - 4 } & 39839 & 62170 & 102009
\end{tabular}

\begin{tabular}{lcc|c} 
& A0 & A1 & \\
D0 & 1220 & 976 & 2196 \\
D1 & 6689 & 7259 & 13948 \\
D2 & 10291 & 12566 & 22857 \\
D3 & 10776 & 18594 & 29371 \\
D4 & 10863 & 22774 & 33637 \\
\cline { 2 - 4 } & 39839 & 62170 & 102009
\end{tabular}
$S Q_{\text {total }}=\sum_{i=1}^{j} \sum_{k=1}^{r} Y_{k}^{2}-C=51.299 .972$

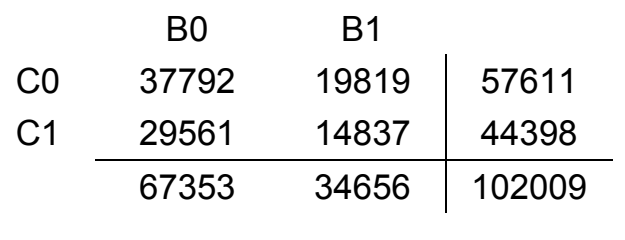

\begin{tabular}{ccc|c} 
& B0 & B1 & \\
D0 & 2196 & 0 & 2196 \\
D1 & 8397 & 5551 & 13948 \\
D2 & 15209 & 7648 & 22857 \\
D3 & 19537 & 9833 & 29371 \\
D4 & 22013 & 11624 & 33637 \\
\cline { 2 - 4 } & 67353 & 34656 & 102009
\end{tabular}

\begin{tabular}{ccc|c} 
& C0 & C1 & \\
D0 & 2196 & 0 & 2196 \\
D1 & 8195 & 5753 & 13948 \\
D2 & 12462 & 10395 & 22857 \\
D3 & 16390 & 12981 & 29371 \\
D4 & 18367 & 15270 & 33637 \\
\cline { 2 - 4 } & 57611 & 44398 & 102009
\end{tabular}




\begin{tabular}{|c|c|c|c|c|c|c|c|}
\hline $\mathrm{AO} ; \mathrm{B0} ; \mathrm{C} 0$ & 14294 & $\mathrm{~A} 0 ; \mathrm{B0} ; \mathrm{DO}$ & 1220 & $\mathrm{~A} 0 ; \mathrm{C} 0 ; \mathrm{DO}$ & 1220 & $\mathrm{BO} ; \mathrm{C0} ; \mathrm{DO}$ & 2196 \\
\hline $\mathrm{A} 1 ; \mathrm{B} 0 ; \mathrm{C} 0$ & 23498 & $\mathrm{~A} 1 ; \mathrm{B} 0 ; \mathrm{D} 0$ & 976 & $\mathrm{~A} 1 ; \mathrm{C} 0 ; \mathrm{D} 0$ & 976 & $\mathrm{~B} 1 ; \mathrm{C} 0 ; \mathrm{D} 0$ & 0 \\
\hline $\mathrm{A} 0 ; \mathrm{B} 1 ; \mathrm{C} 0$ & 8217 & $\mathrm{~A} 0 ; \mathrm{B} 1 ; \mathrm{D} 0$ & 0 & $\mathrm{~A} 0 ; \mathrm{C} 1 ; \mathrm{D} 0$ & 0 & $\mathrm{~B} 0 ; \mathrm{C} 1 ; \mathrm{D} 0$ & 0 \\
\hline $\mathrm{A} 1 ; \mathrm{B} 1 ; \mathrm{C} 0$ & 11602 & $\mathrm{~A} 1 ; \mathrm{B} 1 ; \mathrm{D} 0$ & 0 & $\mathrm{~A} 1 ; \mathrm{C} 1 ; \mathrm{D} 0$ & 0 & $\mathrm{~B} 1 ; \mathrm{C} 1 ; \mathrm{D} 0$ & 0 \\
\hline $\mathrm{A} 0 ; \mathrm{B0} ; \mathrm{C} 1$ & 11146 & $\mathrm{~A} 0 ; \mathrm{B} 0 ; \mathrm{D} 1$ & 4282 & $\mathrm{~A} 0 ; \mathrm{C} 0 ; \mathrm{D} 1$ & 4139 & $\mathrm{~B} 0 ; \mathrm{C} 0 ; \mathrm{D} 1$ & 4805 \\
\hline $\mathrm{A} 1 ; \mathrm{B} 0 ; \mathrm{C} 1$ & 18415 & $\mathrm{~A} 1 ; \mathrm{B} 0 ; \mathrm{D} 1$ & 4115 & $\mathrm{~A} 1 ; \mathrm{C} 0 ; \mathrm{D} 1$ & 4057 & $\mathrm{~B} 1 ; \mathrm{C} 0 ; \mathrm{D} 1$ & 3390 \\
\hline $\mathrm{A} 0 ; \mathrm{B} 1 ; \mathrm{C} 1$ & 6182 & $\mathrm{A0} ; \mathrm{B} 1 ; \mathrm{D} 1$ & 2407 & $\mathrm{~A} 0 ; \mathrm{C} 1 ; \mathrm{D} 1$ & 2550 & $\mathrm{~B} 0 ; \mathrm{C} 1 ; \mathrm{D} 1$ & 3592 \\
\hline \multirow[t]{13}{*}{$\mathrm{A} 1 ; \mathrm{B} 1 ; \mathrm{C} 1$} & 8655 & $\mathrm{~A} 1 ; \mathrm{B} 1 ; \mathrm{D} 1$ & 3144 & $\mathrm{~A} 1 ; \mathrm{C} 1 ; \mathrm{D} 1$ & 3202 & $\mathrm{~B} 1 ; \mathrm{C} 1 ; \mathrm{D} 1$ & 2161 \\
\hline & & $\mathrm{A} 0 ; \mathrm{B} 0 ; \mathrm{D} 2$ & 6515 & $\mathrm{~A} 0 ; \mathrm{C} 0 ; \mathrm{D} 2$ & 5499 & $\mathrm{~B} 0 ; \mathrm{C0} ; \mathrm{D} 2$ & 8048 \\
\hline & & $\mathrm{A} 1 ; \mathrm{B} 0 ; \mathrm{D} 2$ & 8694 & $\mathrm{~A} 1 ; \mathrm{C} 0 ; \mathrm{D} 2$ & 6963 & $\mathrm{~B} 1 ; \mathrm{C} 0 ; \mathrm{D} 2$ & 4414 \\
\hline & & $\mathrm{A} 0 ; \mathrm{B} 1 ; \mathrm{D} 2$ & 3775 & $\mathrm{~A} 0 ; \mathrm{C} 1 ; \mathrm{D} 2$ & 4791 & $\mathrm{~B} 0 ; \mathrm{C} 1 ; \mathrm{D} 2$ & 7161 \\
\hline & & $\mathrm{A} 1 ; \mathrm{B} 1 ; \mathrm{D} 2$ & 3873 & $A 1 ; C 1 ; D 2$ & 5603 & $\mathrm{~B} 1 ; \mathrm{C} 1 ; \mathrm{D} 2$ & 3234 \\
\hline & & $\mathrm{A} 0 ; \mathrm{B} 0 ; \mathrm{D} 3$ & 6839 & $\mathrm{~A} 0 ; \mathrm{C0} ; \mathrm{D} 3$ & 5660 & $\mathrm{~B} 0 ; \mathrm{C} 0 ; \mathrm{D} 3$ & 1073 \\
\hline & & $\mathrm{A} 1 ; \mathrm{B} 0 ; \mathrm{D} 3$ & 12698 & $\mathrm{~A} 1 ; \mathrm{C} 0 ; \mathrm{D} 3$ & 10730 & $\mathrm{~B} 1 ; \mathrm{C} 0 ; \mathrm{D} 3$ & 5651 \\
\hline & & $A 0 ; B 1 ; D 3$ & 3937 & $\mathrm{~A} 0 ; \mathrm{C} 1 ; \mathrm{D} 3$ & 5116 & $\mathrm{~B} 0 ; \mathrm{C} 1 ; \mathrm{D} 3$ & 8799 \\
\hline & & A1;B1;D3 & 5896 & $\mathrm{~A} 1 ; \mathrm{C} 1 ; \mathrm{D} 3$ & 7865 & $\mathrm{~B} 1 ; \mathrm{C} 1 ; \mathrm{D} 3$ & 4182 \\
\hline & & $\mathrm{A} 0 ; \mathrm{B} 0 ; \mathrm{D} 4$ & 6583 & $\mathrm{~A} 0 ; \mathrm{C} 0 ; \mathrm{D} 4$ & 5993 & $\mathrm{BO} ; \mathrm{C} 0 ; \mathrm{D} 4$ & 12003 \\
\hline & & $\mathrm{A} 1 ; \mathrm{B} 0 ; \mathrm{D} 4$ & 15430 & $\mathrm{~A} 1 ; \mathrm{C} 0 ; \mathrm{D} 4$ & 12374 & $\mathrm{~B} 1 ; \mathrm{C} 0 ; \mathrm{D} 4$ & 6364 \\
\hline & & $\mathrm{A} 0 ; \mathrm{B} 1 ; \mathrm{D} 4$ & 4280 & $\mathrm{~A} 0 ; \mathrm{C} 1 ; \mathrm{D} 4$ & 4870 & $\mathrm{~B} 0 ; \mathrm{C} 1 ; \mathrm{D} 4$ & 10010 \\
\hline & & $\mathrm{A} 1 ; \mathrm{B} 1 ; \mathrm{D} 4$ & 7344 & $\mathrm{~A} 1 ; \mathrm{C} 1 ; \mathrm{D} 4$ & 10400 & $\mathrm{~B} 1 ; \mathrm{C} 1 ; \mathrm{D} 4$ & 5260 \\
\hline
\end{tabular}

Resumo das somas de quadrados

\begin{tabular}{cccccccc}
\hline A e BeCeD & 50.843 .318 & A e D & 35.137 .675 & D & 26.447 .289 & ABC & 8.726 \\
A B B C & 15.622 .890 & B e C & 10.451 .736 & AB & 939.022 & ABD & 1.304 .665 \\
A e BeD & 48.722 .827 & B e D & 37.788 .753 & AC & 67.559 & ACD & 229.771 \\
A C C D & 36.946 .605 & Ce D & 27.958 .888 & AD & 4.534 .539 & BCD & 158.842 \\
BeCeD & 39.547 .121 & A & 4.155 .847 & BC & 87.927 & ABCD & 56.067 \\
A e B & 14.003 .903 & B & 8.909 .033 & BD & 2.432 .431 & & \\
A e C & 5.678 .182 & C & 1.454 .776 & CD & 56.824 & & \\
\hline
\end{tabular}

Análise do planejamento fatorial completo com 4 fatores

\begin{tabular}{|c|c|c|c|c|c|c|c|c|}
\hline \multirow{2}{*}{$\begin{array}{l}\text { Fonte } \\
\text { de Var. }\end{array}$} & \multirow{2}{*}{$\begin{array}{l}\text { Soma de } \\
\text { quadrados } \\
\text { (SQ) }\end{array}$} & \multirow{2}{*}{$\begin{array}{l}\text { Graus } \\
\text { de lib. } \\
\text { (GL) }\end{array}$} & \multirow{2}{*}{$\begin{array}{c}\text { Quad } \\
\text { médio } \\
\text { QM=SQ/GL }\end{array}$} & \multirow{2}{*}{$\mathrm{F}_{0}$} & \multirow{2}{*}{$\mathrm{F}_{0,05}$} & \multirow{2}{*}{$F_{0,01}$} & \multicolumn{2}{|c|}{$\mathrm{p}$} \\
\hline & & & & & & & $\mathrm{F}_{0}>\mathrm{F}_{0,05}$ & $\mathrm{~F}_{0}>\mathrm{F}_{0,01}$ \\
\hline A & 4.155 .847 & 1 & 4.155 .847 & 656,54 & 3,92 & 6,85 & Sim & Sim \\
\hline B & 8.909 .033 & 1 & 8.909 .033 & 1407,45 & 3,92 & 6,85 & Sim & Sim \\
\hline C & 1.454 .776 & 1 & 1.454 .776 & 229,83 & 3,92 & 6,85 & Sim & Sim \\
\hline$D$ & 26.447 .289 & 4 & 6.611 .822 & 1044,54 & 2,45 & 3,48 & Sim & Sim \\
\hline$A B$ & 939.022 & 1 & 939.022 & 148,35 & 3,92 & 6,85 & Sim & Sim \\
\hline$A C$ & 67.559 & 1 & 67.559 & 10,67 & 3,92 & 6,85 & Sim & Sim \\
\hline$A D$ & 4.534 .539 & 4 & 1.133 .635 & 179,09 & 2,45 & 3,48 & Sim & Sim \\
\hline BC & 87.927 & 1 & 87.927 & 13,89 & 3,92 & 6,85 & Sim & Sim \\
\hline BD & 2.432 .431 & 4 & 608.108 & 96,07 & 2,45 & 3,48 & Sim & Sim \\
\hline CD & 56.824 & 4 & 14.206 & 2,24 & 2,45 & 3,48 & Não & Não \\
\hline$A B C$ & 8.726 & 4 & 2.181 & 0,34 & 2,45 & 3,48 & Não & Não \\
\hline$A B D$ & 1.304 .665 & 4 & 326.166 & 51,53 & 2,45 & 3,48 & Sim & Sim \\
\hline$A C D$ & 229.771 & 4 & 57.443 & 9,07 & 2,45 & 3,48 & Sim & Sim \\
\hline $\mathrm{BCD}$ & 158.842 & 4 & 39.711 & 6,27 & 2,45 & 3,48 & Sim & Sim \\
\hline ERRO & 512.721 & 81 & 6.330 & & & & & \\
\hline TOTAL & 51.299 .972 & 119 & 431.092 & & & & & \\
\hline
\end{tabular}




\section{Experimento fatorial para o ensaio de resistência à compressão diametral para o teor de $10 \%$ de cal.}

Fatores

\begin{tabular}{|c|c|c|c|c|c|}
\hline & & Níveis & Descripção & & Repetições $r=3$ \\
\hline \multirow[t]{2}{*}{ A } & Tipo de solo & 2 & 0 & LG' & \\
\hline & & & 1 & NG' & \\
\hline \multirow[t]{2}{*}{ B } & Teor de resíduo & 2 & 0 & $0 \%$ & \\
\hline & & & 1 & $40 \%$ & \\
\hline \multirow[t]{2}{*}{ C } & Condição de imersão & 2 & 0 & Não imerso & \\
\hline & & & 1 & Imerso & \\
\hline \multirow[t]{6}{*}{ D } & Tempo de cura & 5 & 0 & 0 & \\
\hline & & & 1 & 2 & \\
\hline & & & 2 & 7 & \\
\hline & & & 3 & 28 & \\
\hline & & & 4 & 84 & \\
\hline & $\mathrm{m}=$ & 40 & & & \\
\hline
\end{tabular}

\begin{tabular}{|c|c|c|c|c|c|c|c|c|c|c|c|}
\hline \multirow{3}{*}{$\begin{array}{l}\text { Cond. } \\
\text { Exp. } \\
\text { (j) }\end{array}$} & \multirow{3}{*}{$\begin{array}{c}\text { A } \\
\text { Tipo } \\
\text { de } \\
\text { solo }\end{array}$} & \multirow{3}{*}{$\begin{array}{c}\text { B } \\
\text { Teor } \\
\text { de } \\
\text { resíduo }\end{array}$} & \multirow{3}{*}{$\begin{array}{c}\text { C } \\
\text { Condição } \\
\text { de } \\
\text { imersão }\end{array}$} & \multirow{3}{*}{$\begin{array}{c}\text { D } \\
\text { Tempo } \\
\text { de } \\
\text { cura }\end{array}$} & \multirow{2}{*}{\multicolumn{3}{|c|}{$\frac{\text { RCS }}{\text { Repetição }}$}} & \multirow{3}{*}{$\begin{array}{c}\text { Totais } \\
\text { parciais } \\
\text { T(c) }\end{array}$} & \multirow{3}{*}{$r$} & \multirow{3}{*}{$\mathrm{T}(\mathrm{c}) / \mathrm{r}$} & \multirow{3}{*}{$\sum_{k=1}^{r} Y_{K}^{2}$} \\
\hline & & & & & & & & & & & \\
\hline & & & & & Y1 & Y2 & Y3 & & & & \\
\hline 1 & 0 & 0 & 0 & 0 & 0 & 0 & 0 & 0 & 3 & 0 & 0 \\
\hline 2 & 1 & 0 & 0 & 0 & 0 & 0 & 0 & 0 & 3 & 0 & 0 \\
\hline 3 & 0 & 1 & 0 & 0 & 0 & 0 & 0 & 0 & 3 & 0 & 0 \\
\hline 4 & 1 & 1 & 0 & 0 & 0 & 0 & 0 & 0 & 3 & 0 & 0 \\
\hline 5 & 0 & 0 & 1 & 0 & 0 & 0 & 0 & 0 & 3 & 0 & 0 \\
\hline 6 & 1 & 0 & 1 & 0 & 0 & 0 & 0 & 0 & 3 & 0 & 0 \\
\hline 7 & 0 & 1 & 1 & 0 & 0 & 0 & 0 & 0 & 3 & 0 & 0 \\
\hline 8 & 1 & 1 & 1 & 0 & 0 & 0 & 0 & 0 & 3 & 0 & 0 \\
\hline 9 & 0 & 0 & 0 & 1 & 103 & 106 & 112 & 321 & 3 & 107 & 34332 \\
\hline 10 & 1 & 0 & 0 & 1 & 91 & 92 & 95 & 278 & 3 & 93 & 25767 \\
\hline 11 & 0 & 1 & 0 & 1 & 94 & 100 & 106 & 301 & 3 & 100 & 30305 \\
\hline 12 & 1 & 1 & 0 & 1 & 68 & 68 & 74 & 211 & 3 & 70 & 14818 \\
\hline 13 & 0 & 0 & 1 & 1 & 69 & 69 & 74 & 212 & 3 & 71 & 14992 \\
\hline 14 & 1 & 0 & 1 & 1 & 81 & 83 & 86 & 250 & 3 & 83 & 20822 \\
\hline 15 & 0 & 1 & 1 & 1 & 58 & 63 & 63 & 184 & 3 & 61 & 11279 \\
\hline 16 & 1 & 1 & 1 & 1 & 48 & 51 & 54 & 154 & 3 & 51 & 7875 \\
\hline 17 & 0 & 0 & 0 & 2 & 139 & 144 & 144 & 427 & 3 & 142 & 60827 \\
\hline 18 & 1 & 0 & 0 & 2 & 172 & 177 & 190 & 539 & 3 & 180 & 96952 \\
\hline 19 & 0 & 1 & 0 & 2 & 115 & 115 & 120 & 351 & 3 & 117 & 41000 \\
\hline 20 & 1 & 1 & 0 & 2 & 113 & 119 & 125 & 357 & 3 & 119 & 42461 \\
\hline 21 & 0 & 0 & 1 & 2 & 115 & 121 & 126 & 362 & 3 & 121 & 43689 \\
\hline 22 & 1 & 0 & 1 & 2 & 165 & 166 & 166 & 498 & 3 & 166 & 82562 \\
\hline 23 & 0 & 1 & 1 & 2 & 83 & 86 & 92 & 260 & 3 & 87 & 22610 \\
\hline 24 & 1 & 1 & 1 & 2 & 63 & 79 & 85 & 227 & 3 & 76 & 17402 \\
\hline 25 & 0 & 0 & 0 & 3 & 138 & 150 & 162 & 450 & 3 & 150 & 67781 \\
\hline
\end{tabular}




\begin{tabular}{cccccccccccc}
26 & 1 & 0 & 0 & 3 & 309 & 315 & 326 & 950 & 3 & 317 & 300749 \\
27 & 0 & 1 & 0 & 3 & 155 & 161 & 166 & 482 & 3 & 161 & 77443 \\
28 & 1 & 1 & 0 & 3 & 211 & 216 & 222 & 649 & 3 & 216 & 140534 \\
29 & 0 & 0 & 1 & 3 & 130 & 130 & 130 & 389 & 3 & 130 & 50407 \\
30 & 1 & 0 & 1 & 3 & 275 & 298 & 303 & 876 & 3 & 292 & 256121 \\
31 & 0 & 1 & 1 & 3 & 115 & 126 & 132 & 373 & 3 & 124 & 46421 \\
32 & 1 & 1 & 1 & 3 & 142 & 154 & 159 & 455 & 3 & 152 & 69286 \\
33 & 0 & 0 & 0 & 4 & 162 & 179 & 202 & 543 & 3 & 181 & 99000 \\
34 & 1 & 0 & 0 & 4 & 325 & 349 & 377 & 1052 & 3 & 351 & 370218 \\
35 & 0 & 1 & 0 & 4 & 154 & 166 & 172 & 492 & 3 & 164 & 80963 \\
36 & 1 & 1 & 0 & 4 & 295 & 301 & 306 & 902 & 3 & 301 & 271194 \\
37 & 0 & 0 & 1 & 4 & 150 & 153 & 156 & 458 & 3 & 153 & 70057 \\
38 & 1 & 0 & 1 & 4 & 332 & 332 & 366 & 1030 & 3 & 343 & 354198 \\
39 & 0 & 1 & 1 & 4 & 143 & 143 & 149 & 435 & 3 & 145 & 63103 \\
40 & 1 & 1 & 1 & 4 & 205 & 210 & 222 & 637 & 3 & 212 & 135220 \\
\hline
\end{tabular}

$$
C=\frac{\left(\sum_{i=1}^{j} T_{i}\right)^{2}}{\sum r}=45.303 \quad S Q_{\text {total }}=\sum_{i=1}^{j} \sum_{k=1}^{r} Y_{k}^{2}-C=1.120 .033
$$

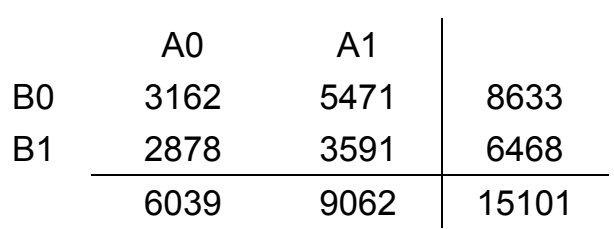

\begin{tabular}{ccc|c} 
& A0 & A1 & \\
C0 & 3367 & 4937 & 8303 \\
C1 & 2673 & 4125 & 6798 \\
\hline & 6039 & 9062 & 15101
\end{tabular}

\begin{tabular}{lcc|c} 
& A0 & A1 & \\
D0 & 0 & 0 & 0 \\
D1 & 1018 & 892 & 1910 \\
D2 & 1400 & 1620 & 3020 \\
D3 & 1693 & 2930 & 4623 \\
D4 & 1928 & 3620 & 5549 \\
\cline { 2 - 4 } & 6039 & 9062 & 15101
\end{tabular}
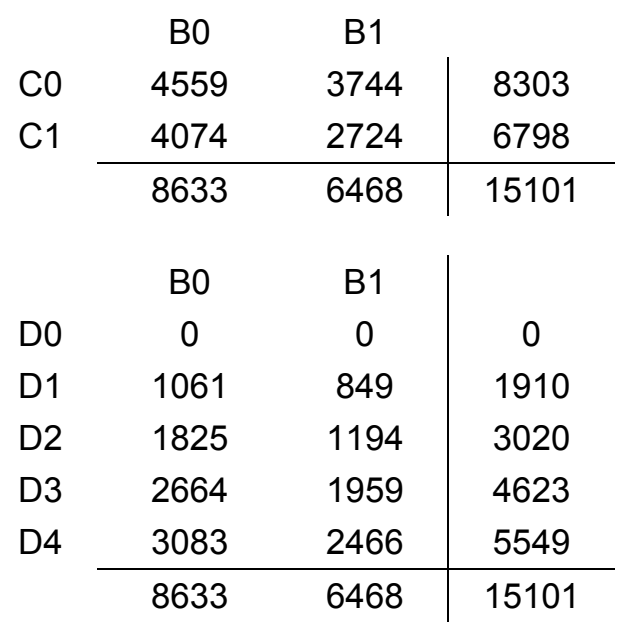

\begin{tabular}{ccc|c} 
& C0 & C1 & \\
D0 & 0 & 0 & 0 \\
D1 & 1111 & 799 & 1910 \\
D2 & 1673 & 1346 & 3020 \\
D3 & 2531 & 2093 & 4623 \\
D4 & 2989 & 2560 & 5549 \\
\cline { 2 - 4 } & 8303 & 6798 & 15101
\end{tabular}




\begin{tabular}{|c|c|c|c|c|c|c|c|}
\hline $\mathrm{AO} ; \mathrm{BO} ; \mathrm{CO}$ & $\mid 1741$ & $\mathrm{~A} 0 ; \mathrm{BO} ; \mathrm{DO}$ & 0 & $\mathrm{~A} 0 ; \mathrm{C0} ; \mathrm{D0}$ & 0 & $\mathrm{BO} ; \mathrm{C0} ; \mathrm{D0}$ & 0 \\
\hline $\mathrm{A} 1 ; \mathrm{B} 0 ; \mathrm{C} 0$ & 2818 & $\mathrm{~A} 1 ; \mathrm{B} 0 ; \mathrm{D} 0$ & 0 & $\mathrm{~A} 1 ; \mathrm{C} 0 ; \mathrm{D} 0$ & 0 & $\mathrm{~B} 1 ; \mathrm{C} 0 ; \mathrm{D} 0$ & 0 \\
\hline $\mathrm{A} 0 ; \mathrm{B} 1 ; \mathrm{C} 0$ & 1626 & $\mathrm{A0} ; \mathrm{B} 1 ; \mathrm{D0}$ & 0 & A0;C1;D0 & 0 & $\mathrm{~B} 0 ; \mathrm{C} 1 ; \mathrm{D} 0$ & 0 \\
\hline $\mathrm{A} 1 ; \mathrm{B} 1 ; \mathrm{C} 0$ & 2118 & $\mathrm{~A} 1 ; \mathrm{B} 1 ; \mathrm{D} 0$ & 0 & A1;C1;D0 & 0 & $\mathrm{~B} 1 ; \mathrm{C} 1 ; \mathrm{D} 0$ & 0 \\
\hline $\mathrm{A} 0 ; \mathrm{B} 0 ; \mathrm{C} 1$ & 1421 & $\mathrm{A0} ; \mathrm{B0} ; \mathrm{D} 1$ & 533 & $\mathrm{~A} 0 ; \mathrm{C} 0 ; \mathrm{D} 1$ & 622 & $\mathrm{~B} 0 ; \mathrm{C0} ; \mathrm{D} 1$ & 599 \\
\hline $\mathrm{A} 1 ; \mathrm{B} 0 ; \mathrm{C} 1$ & 2653 & $\mathrm{~A} 1 ; \mathrm{B} 0 ; \mathrm{D} 1$ & 528 & $\mathrm{~A} 1 ; \mathrm{C} 0 ; \mathrm{D} 1$ & 489 & $\mathrm{~B} 1 ; \mathrm{C} 0 ; \mathrm{D} 1$ & 512 \\
\hline $\mathrm{A} 0 ; \mathrm{B} 1 ; \mathrm{C} 1$ & 1252 & $\mathrm{~A} 0 ; \mathrm{B} 1 ; \mathrm{D} 1$ & 485 & $\mathrm{~A} 0 ; \mathrm{C} 1 ; \mathrm{D} 1$ & 396 & $\mathrm{~B} 0 ; \mathrm{C} 1 ; \mathrm{D} 1$ & 462 \\
\hline \multirow[t]{13}{*}{$\mathrm{A} 1 ; \mathrm{B} 1 ; \mathrm{C} 1$} & 1472 & $\mathrm{~A} 1 ; \mathrm{B} 1 ; \mathrm{D} 1$ & 364 & $\mathrm{~A} 1 ; \mathrm{C} 1 ; \mathrm{D} 1$ & 403 & $\mathrm{~B} 1 ; \mathrm{C} 1 ; \mathrm{D} 1$ & 337 \\
\hline & & $\mathrm{A} 0 ; \mathrm{B} 0 ; \mathrm{D} 2$ & 789 & $\mathrm{~A} 0 ; \mathrm{C} 0 ; \mathrm{D} 2$ & 778 & $\mathrm{~B} 0 ; \mathrm{C0} ; \mathrm{D} 2$ & 966 \\
\hline & & $\mathrm{A} 1 ; \mathrm{B} 0 ; \mathrm{D} 2$ & 1037 & $\mathrm{~A} 1 ; \mathrm{C} 0 ; \mathrm{D} 2$ & 895 & $\mathrm{~B} 1 ; \mathrm{C} 0 ; \mathrm{D} 2$ & 707 \\
\hline & & $\mathrm{A} 0 ; \mathrm{B} 1 ; \mathrm{D} 2$ & 611 & $\mathrm{~A} 0 ; \mathrm{C} 1 ; \mathrm{D} 2$ & 622 & $\mathrm{~B} 0 ; \mathrm{C} 1 ; \mathrm{D} 2$ & 859 \\
\hline & & $\mathrm{A} 1 ; \mathrm{B} 1 ; \mathrm{D} 2$ & 583 & $\mathrm{~A} 1 ; \mathrm{C} 1 ; \mathrm{D} 2$ & 724 & $\mathrm{~B} 1 ; \mathrm{C} 1 ; \mathrm{D} 2$ & 487 \\
\hline & & $\mathrm{A} 0 ; \mathrm{B} 0 ; \mathrm{D} 3$ & 839 & $\mathrm{~A} 0 ; \mathrm{C0} ; \mathrm{D} 3$ & 932 & $\mathrm{~B} 0 ; \mathrm{C} 0 ; \mathrm{D} 3$ & 1400 \\
\hline & & $\mathrm{A} 1 ; \mathrm{B} 0 ; \mathrm{D} 3$ & 1825 & $\mathrm{~A} 1 ; \mathrm{C} 0 ; \mathrm{D} 3$ & 1599 & $\mathrm{~B} 1 ; \mathrm{C} 0 ; \mathrm{D} 3$ & 1131 \\
\hline & & $\mathrm{A} 0 ; \mathrm{B} 1 ; \mathrm{D} 3$ & 854 & A0;C1;D3 & 761 & B0;C1;D3 & 1265 \\
\hline & & $\mathrm{A} 1 ; \mathrm{B} 1 ; \mathrm{D} 3$ & 1105 & A1;C1;D3 & 1331 & $\mathrm{~B} 1 ; \mathrm{C} 1 ; \mathrm{D} 3$ & 828 \\
\hline & & $\mathrm{A} 0 ; \mathrm{B} 0 ; \mathrm{D} 4$ & 1001 & $\mathrm{A0} ; \mathrm{C0} ; \mathrm{D} 4$ & 1035 & $\mathrm{B0} ; \mathrm{C0} ; \mathrm{D} 4$ & 1595 \\
\hline & & $\mathrm{A} 1 ; \mathrm{B} 0 ; \mathrm{D} 4$ & 2082 & $\mathrm{~A} 1 ; \mathrm{C} 0 ; \mathrm{D} 4$ & 1954 & $\mathrm{~B} 1 ; \mathrm{C} 0 ; \mathrm{D} 4$ & 1394 \\
\hline & & $\mathrm{A} 0 ; \mathrm{B} 1 ; \mathrm{D} 4$ & 927 & $\mathrm{~A} 0 ; \mathrm{C} 1 ; \mathrm{D} 4$ & 893 & $\mathrm{~B} 0 ; \mathrm{C} 1 ; \mathrm{D} 4$ & 1488 \\
\hline & & $\mathrm{A} 1 ; \mathrm{B} 1 ; \mathrm{D} 4$ & 1538 & $\mathrm{~A} 1 ; \mathrm{C} 1 ; \mathrm{D} 4$ & 1666 & $\mathrm{~B} 1 ; \mathrm{C} 1 ; \mathrm{D} 4$ & 1072 \\
\hline
\end{tabular}

Resumo das somas de quadrados

\begin{tabular}{crcrcrrr}
\hline A e BeCeD & 1.114 .501 & A e D & 990.521 & D & 804.881 & ABC & 1.513 \\
A B B C & 159.361 & B e C & 60.333 & AB & 21.247 & ABD & 14.239 \\
A B BeD & 1.081 .060 & B e D & 859.934 & AC & 115 & ACD & 2.003 \\
A C e D & 1.016 .801 & C e D & 829.043 & AD & 109.487 & BCD & 1.331 \\
Be GeD & 887.816 & A & 76.153 & BC & 2.389 & ABCD & 1.929 \\
A e B & 136.455 & B & 39.055 & BD & 15.998 & & \\
A e C & 95.157 & C & 18.889 & CD & 5.274 & & \\
\hline
\end{tabular}

Análise do planejamento fatorial completo com 4 fatores

\begin{tabular}{|c|c|c|c|c|c|c|c|c|}
\hline \multirow{2}{*}{$\begin{array}{l}\text { Fonte } \\
\text { de Var. }\end{array}$} & \multirow{2}{*}{$\begin{array}{l}\text { Soma de } \\
\text { quadrados } \\
\text { (SQ) }\end{array}$} & \multirow{2}{*}{$\begin{array}{c}\text { Graus } \\
\text { de lib. } \\
\text { (GL) }\end{array}$} & \multirow{2}{*}{$\begin{array}{c}\text { Quad } \\
\text { médio } \\
\mathrm{QM}=S Q / G L\end{array}$} & \multirow{2}{*}{$\mathrm{F}_{0}$} & \multirow{2}{*}{$\mathrm{F}_{0,05}$} & \multirow{2}{*}{$F_{0,01}$} & \multicolumn{2}{|c|}{$\mathrm{p}$} \\
\hline & & & & & & & $F_{0}>F_{0,05}$ & $\mathrm{~F}_{0}>\mathrm{F}_{0,01}$ \\
\hline A & 76.153 & 1 & 76.153 & 826,83 & 3,92 & 6,85 & Sim & Sim \\
\hline B & 39.055 & 1 & 39.055 & 424,04 & 3,92 & 6,85 & Sim & Sim \\
\hline C & 18.889 & 1 & 18.889 & 205,08 & 3,92 & 6,85 & Sim & Sim \\
\hline $\mathrm{D}$ & 804.881 & 4 & 201.220 & 2184,76 & 2,45 & 3,48 & Sim & Sim \\
\hline$A B$ & 21.247 & 1 & 21.247 & 230,69 & 3,92 & 6,85 & Sim & Sim \\
\hline$A C$ & 115 & 1 & 115 & 1,25 & 3,92 & 6,85 & Não & Não \\
\hline$A D$ & 109.487 & 4 & 27.372 & 297,19 & 2,45 & 3,48 & Sim & Sim \\
\hline$B C$ & 2.389 & 1 & 2.389 & 25,94 & 3,92 & 6,85 & Sim & Sim \\
\hline BD & 15.998 & 4 & 4.000 & 43,43 & 2,45 & 3,48 & Sim & Sim \\
\hline$C D$ & 5.274 & 4 & 1.318 & 14,31 & 2,45 & 3,48 & Sim & Sim \\
\hline$A B C$ & 1.513 & 4 & 378 & 4,11 & 2,45 & 3,48 & Sim & Sim \\
\hline$A B D$ & 14.239 & 4 & 3.560 & 38,65 & 2,45 & 3,48 & Sim & Sim \\
\hline$A C D$ & 2.003 & 4 & 501 & 5,44 & 2,45 & 3,48 & Sim & Sim \\
\hline$B C D$ & 1.331 & 4 & 333 & 3,61 & 2,45 & 3,48 & Sim & Sim \\
\hline ERRO & 7.460 & 81 & 92 & & & & & \\
\hline TOTAL & 1.120 .033 & 119 & 9.412 & & & & & \\
\hline
\end{tabular}




\section{Experimento fatorial para o módulo tangente inicial para o teor de $10 \%$ de cal.}

\section{Fatores}

\begin{tabular}{|c|c|c|c|c|c|}
\hline & & Níveis & Descripção & & Repetições $r=3$ \\
\hline \multirow[t]{2}{*}{ A } & Tipo de solo & 2 & 0 & LG' & \\
\hline & & & 1 & NG' & \\
\hline \multirow[t]{2}{*}{ B } & Teor de resíduo & 2 & 0 & $0 \%$ & \\
\hline & & & 1 & $40 \%$ & \\
\hline \multirow[t]{2}{*}{ C } & Condição de imersão & 2 & 0 & Não imerso & \\
\hline & & & 1 & Imerso & \\
\hline \multirow[t]{6}{*}{ D } & Tempo de cura & 5 & 0 & 0 & \\
\hline & & & 1 & 2 & \\
\hline & & & 2 & 7 & \\
\hline & & & 3 & 28 & \\
\hline & & & 4 & 84 & \\
\hline & $\mathrm{m}=$ & 40 & & & \\
\hline
\end{tabular}

\begin{tabular}{|c|c|c|c|c|c|c|c|c|c|c|c|}
\hline \multirow{3}{*}{$\begin{array}{l}\text { Cond. } \\
\text { Exp. } \\
\text { (j) }\end{array}$} & \multirow{3}{*}{$\begin{array}{c}\text { A } \\
\text { Tipo } \\
\text { de } \\
\text { solo }\end{array}$} & \multirow{3}{*}{$\begin{array}{c}\text { B } \\
\text { Teor } \\
\text { de } \\
\text { resíduo }\end{array}$} & \multirow{3}{*}{$\begin{array}{c}\text { C } \\
\begin{array}{c}\text { Condição } \\
\text { de } \\
\text { imersão }\end{array}\end{array}$} & \multirow{3}{*}{$\begin{array}{c}\text { D } \\
\begin{array}{c}\text { Tempo } \\
\text { de } \\
\text { cura }\end{array}\end{array}$} & \multirow{2}{*}{\multicolumn{3}{|c|}{$\frac{\text { RCS }}{\text { Repetição }}$}} & \multirow{3}{*}{$\begin{array}{c}\text { Totais } \\
\text { parciais } \\
\mathrm{T}(\mathrm{c})\end{array}$} & \multirow{3}{*}{$r$} & \multirow{3}{*}{$\mathrm{T}(\mathrm{c}) / \mathrm{r}$} & \multirow{3}{*}{$\sum_{k=1}^{r} Y_{K}^{2}$} \\
\hline & & & & & & & & & & & \\
\hline & & & & & Y1 & Y2 & Y3 & & & & \\
\hline 1 & 0 & 0 & 0 & 0 & 91 & 97 & 103 & 291 & 3 & 97 & 28299 \\
\hline 2 & 1 & 0 & 0 & 0 & 54 & 57 & 58 & 169 & 3 & 56 & 9529 \\
\hline 3 & 0 & 1 & 0 & 0 & 0 & 0 & 0 & 0 & 3 & 0 & 0 \\
\hline 4 & 1 & 1 & 0 & 0 & 0 & 0 & 0 & 0 & 3 & 0 & 0 \\
\hline 5 & 0 & 0 & 1 & 0 & 0 & 0 & 0 & 0 & 3 & 0 & 0 \\
\hline 6 & 1 & 0 & 1 & 0 & 0 & 0 & 0 & 0 & 3 & 0 & 0 \\
\hline 7 & 0 & 1 & 1 & 0 & 0 & 0 & 0 & 0 & 3 & 0 & 0 \\
\hline 8 & 1 & 1 & 1 & 0 & 0 & 0 & 0 & 0 & 3 & 0 & 0 \\
\hline 9 & 0 & 0 & 0 & 1 & 155 & 340 & 358 & 853 & 3 & 284 & 267789 \\
\hline 10 & 1 & 0 & 0 & 1 & 113 & 193 & 361 & 667 & 3 & 222 & 180339 \\
\hline 11 & 0 & 1 & 0 & 1 & 178 & 235 & 287 & 700 & 3 & 233 & 169278 \\
\hline 12 & 1 & 1 & 0 & 1 & 86 & 105 & 125 & 316 & 3 & 105 & 34046 \\
\hline 13 & 0 & 0 & 1 & 1 & 55 & 200 & 214 & 469 & 3 & 156 & 88821 \\
\hline 14 & 1 & 0 & 1 & 1 & 129 & 133 & 136 & 398 & 3 & 133 & 52826 \\
\hline 15 & 0 & 1 & 1 & 1 & 134 & 207 & 210 & 551 & 3 & 184 & 104905 \\
\hline 16 & 1 & 1 & 1 & 1 & 91 & 92 & 201 & 384 & 3 & 128 & 57146 \\
\hline 17 & 0 & 0 & 0 & 2 & 848 & 958 & 960 & 2766 & 3 & 922 & 2558468 \\
\hline 18 & 1 & 0 & 0 & 2 & 1234 & 1375 & 1420 & 4029 & 3 & 1343 & 5429781 \\
\hline 19 & 0 & 1 & 0 & 2 & 357 & 390 & 420 & 1167 & 3 & 389 & 455949 \\
\hline 20 & 1 & 1 & 0 & 2 & 227 & 252 & 259 & 738 & 3 & 246 & 182114 \\
\hline 21 & 0 & 0 & 1 & 2 & 406 & 676 & 677 & 1759 & 3 & 586 & 1080141 \\
\hline 22 & 1 & 0 & 1 & 2 & 1249 & 1252 & 1584 & 4085 & 3 & 1362 & 5636561 \\
\hline 23 & 0 & 1 & 1 & 2 & 333 & 352 & 352 & 1037 & 3 & 346 & 358697 \\
\hline 24 & 1 & 1 & 1 & 2 & 198 & 211 & 343 & 752 & 3 & 251 & 201374 \\
\hline 25 & 0 & 0 & 0 & 3 & 213 & 978 & 1049 & 2240 & 3 & 747 & 2102254 \\
\hline
\end{tabular}




\begin{tabular}{cccccccccccc}
26 & 1 & 0 & 0 & 3 & 1821 & 1869 & 1915 & 5605 & 3 & 1868 & 10476427 \\
27 & 0 & 1 & 0 & 3 & 276 & 422 & 429 & 1127 & 3 & 376 & 438301 \\
28 & 1 & 1 & 0 & 3 & 613 & 684 & 878 & 2175 & 3 & 725 & 1614509 \\
29 & 0 & 0 & 1 & 3 & 436 & 734 & 740 & 1910 & 3 & 637 & 1276452 \\
30 & 1 & 0 & 1 & 3 & 491 & 1349 & 1362 & 3202 & 3 & 1067 & 3915926 \\
31 & 0 & 1 & 1 & 3 & 367 & 391 & 400 & 1158 & 3 & 386 & 447570 \\
32 & 1 & 1 & 1 & 3 & 625 & 665 & 1075 & 2365 & 3 & 788 & 1988475 \\
33 & 0 & 0 & 0 & 4 & 1064 & 1117 & 1196 & 3377 & 3 & 1126 & 3810201 \\
34 & 1 & 0 & 0 & 4 & 1820 & 2130 & 5140 & 9090 & 3 & 3030 & 34268900 \\
35 & 0 & 1 & 0 & 4 & 215 & 474 & 482 & 1171 & 3 & 390 & 503225 \\
36 & 1 & 1 & 0 & 4 & 971 & 1061 & 1138 & 3170 & 3 & 1057 & 3363606 \\
37 & 0 & 0 & 1 & 4 & 680 & 881 & 881 & 2442 & 3 & 814 & 2014722 \\
38 & 1 & 0 & 1 & 4 & 1252 & 1344 & 1630 & 4226 & 3 & 1409 & 6030740 \\
39 & 0 & 1 & 1 & 4 & 250 & 368 & 665 & 1283 & 3 & 428 & 640149 \\
40 & 1 & 1 & 1 & 4 & 809 & 918 & 2006 & 3733 & 3 & 1244 & 5521241 \\
\hline
\end{tabular}

$$
C=\frac{\left(\sum_{i=1}^{j} T_{i}\right)^{2}}{\sum r}=208.215 \quad S Q_{\text {total }}=\sum_{i=1}^{j} \sum_{k=1}^{r} Y_{k}^{2}-C=55.166 .644
$$
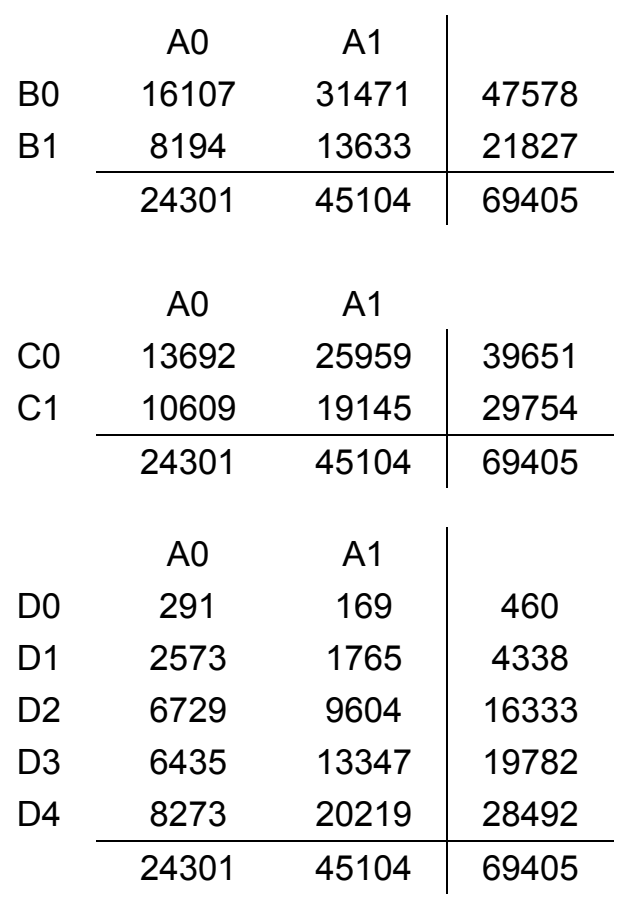

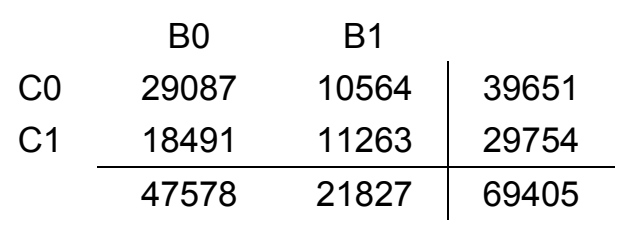

\begin{tabular}{ccc|c} 
& B0 & B1 & \\
D0 & 460 & 0 & 460 \\
D1 & 2387 & 1951 & 4338 \\
D2 & 12639 & 3694 & 16333 \\
D3 & 12957 & 6825 & 19782 \\
D4 & 19135 & 9357 & 28492 \\
\cline { 2 - 4 } & 47578 & 21827 & 69405
\end{tabular}

\begin{tabular}{ccc|c} 
& C0 & C1 & \\
D0 & 460 & 0 & 460 \\
D1 & 2536 & 1802 & 4338 \\
D2 & 8700 & 7633 & 16333 \\
D3 & 11147 & 8635 & 19782 \\
D4 & 16808 & 11684 & 28492 \\
\cline { 2 - 4 } & 39651 & 29754 & 69405
\end{tabular}




\begin{tabular}{|c|c|c|c|c|c|c|c|}
\hline $\mathrm{AO} ; \mathrm{BO} ; \mathrm{CO}$ & 9527 & $\mathrm{AO} ; \mathrm{B0} ; \mathrm{D0}$ & 291 & $\mathrm{~A} 0 ; \mathrm{C} 0 ; \mathrm{DO}$ & 291 & $\mathrm{~B} 0 ; \mathrm{C} 0 ; \mathrm{D0}$ & 460 \\
\hline $\mathrm{A} 1 ; \mathrm{B} 0 ; \mathrm{C} 0$ & 19560 & $\mathrm{~A} 1 ; \mathrm{B} 0 ; \mathrm{D0}$ & 169 & $\mathrm{~A} 1 ; \mathrm{C} 0 ; \mathrm{D} 0$ & 169 & $\mathrm{~B} 1 ; \mathrm{C} 0 ; \mathrm{D} 0$ & 0 \\
\hline $\mathrm{A} 0 ; \mathrm{B} 1 ; \mathrm{C} 0$ & 4165 & $A 0 ; B 1 ; D 0$ & 0 & $\mathrm{~A} 0 ; \mathrm{C} 1 ; \mathrm{D} 0$ & 0 & B0;C1;D0 & 0 \\
\hline $\mathrm{A} 1 ; \mathrm{B} 1 ; \mathrm{C} 0$ & 6399 & $A 1 ; B 1 ; D 0$ & 0 & $\mathrm{~A} 1 ; \mathrm{C} 1 ; \mathrm{D} 0$ & 0 & $\mathrm{~B} 1 ; \mathrm{C} 1 ; \mathrm{D} 0$ & 0 \\
\hline $\mathrm{A} 0 ; \mathrm{B} 0 ; \mathrm{C} 1$ & 6580 & $\mathrm{~A} 0 ; \mathrm{B0} ; \mathrm{D} 1$ & 1322 & $\mathrm{~A} 0 ; \mathrm{C} 0 ; \mathrm{D} 1$ & 1553 & $\mathrm{B0} ; \mathrm{C0} ; \mathrm{D} 1$ & 1520 \\
\hline $\mathrm{A} 1 ; \mathrm{B} 0 ; \mathrm{C} 1$ & 11911 & $\mathrm{~A} 1 ; \mathrm{B} 0 ; \mathrm{D} 1$ & 1065 & $\mathrm{~A} 1 ; \mathrm{C} 0 ; \mathrm{D} 1$ & 983 & $\mathrm{~B} 1 ; \mathrm{C} 0 ; \mathrm{D} 1$ & 1016 \\
\hline $\mathrm{A} 0 ; \mathrm{B} 1 ; \mathrm{C} 1$ & 4029 & A0;B1;D1 & 1251 & $\mathrm{~A} 0 ; \mathrm{C} 1 ; \mathrm{D} 1$ & 1020 & $\mathrm{~B} 0 ; \mathrm{C} 1 ; \mathrm{D} 1$ & 867 \\
\hline \multirow[t]{13}{*}{$\mathrm{A} 1 ; \mathrm{B} 1 ; \mathrm{C} 1$} & 7234 & $A 1 ; B 1 ; D 1$ & 700 & $\mathrm{~A} 1 ; \mathrm{C} 1 ; \mathrm{D} 1$ & 782 & $\mathrm{~B} 1 ; \mathrm{C} 1 ; \mathrm{D} 1$ & 935 \\
\hline & & $\mathrm{A} 0 ; \mathrm{B} 0 ; \mathrm{D} 2$ & 4525 & $\mathrm{~A} 0 ; \mathrm{C} 0 ; \mathrm{D} 2$ & 3933 & $\mathrm{~B} 0 ; \mathrm{C0} ; \mathrm{D} 2$ & 6795 \\
\hline & & $\mathrm{A} 1 ; \mathrm{B} 0 ; \mathrm{D} 2$ & 8114 & $\mathrm{~A} 1 ; \mathrm{C} 0 ; \mathrm{D} 2$ & 4767 & $\mathrm{~B} 1 ; \mathrm{C} 0 ; \mathrm{D} 2$ & 1905 \\
\hline & & $\mathrm{A} 0 ; \mathrm{B} 1 ; \mathrm{D} 2$ & 2204 & $\mathrm{~A} 0 ; \mathrm{C} 1 ; \mathrm{D} 2$ & 2796 & $\mathrm{~B} 0 ; \mathrm{C} 1 ; \mathrm{D} 2$ & 5844 \\
\hline & & $A 1 ; B 1 ; D 2$ & 1490 & $A 1 ; C 1 ; D 2$ & 4837 & $\mathrm{~B} 1 ; \mathrm{C} 1 ; \mathrm{D} 2$ & 1789 \\
\hline & & $\mathrm{A} 0 ; \mathrm{B} 0 ; \mathrm{D} 3$ & 4150 & $\mathrm{~A} 0 ; \mathrm{C0} ; \mathrm{D} 3$ & 3367 & B0;C0;D3 & 7845 \\
\hline & & $\mathrm{A} 1 ; \mathrm{B} 0 ; \mathrm{D} 3$ & 8807 & $\mathrm{~A} 1 ; \mathrm{C} 0 ; \mathrm{D} 3$ & 7780 & $\mathrm{~B} 1 ; \mathrm{C} 0 ; \mathrm{D} 3$ & 3302 \\
\hline & & $A 0 ; B 1 ; D 3$ & 2285 & $\mathrm{~A} 0 ; \mathrm{C} 1 ; \mathrm{D} 3$ & 3068 & $\mathrm{~B} 0 ; \mathrm{C} 1 ; \mathrm{D} 3$ & 5112 \\
\hline & & $\mathrm{A} 1 ; \mathrm{B} 1 ; \mathrm{D} 3$ & 4540 & $\mathrm{~A} 1 ; \mathrm{C} 1 ; \mathrm{D} 3$ & 5567 & $\mathrm{~B} 1 ; \mathrm{C} 1 ; \mathrm{D} 3$ & 3523 \\
\hline & & $\mathrm{A} 0 ; \mathrm{B} 0 ; \mathrm{D} 4$ & 5819 & $\mathrm{~A} 0 ; \mathrm{C} 0 ; \mathrm{D} 4$ & 4548 & $\mathrm{~B} 0 ; \mathrm{C0} ; \mathrm{D} 4$ & 12467 \\
\hline & & $\mathrm{A} 1 ; \mathrm{B} 0 ; \mathrm{D} 4$ & 13316 & $\mathrm{~A} 1 ; \mathrm{C} 0 ; \mathrm{D} 4$ & 12260 & $\mathrm{~B} 1 ; \mathrm{C} 0 ; \mathrm{D} 4$ & 4341 \\
\hline & & A0;B1;D4 & 2454 & $\mathrm{~A} 0 ; \mathrm{C} 1 ; \mathrm{D} 4$ & 3725 & $\mathrm{~B} 0 ; \mathrm{C} 1 ; \mathrm{D} 4$ & 6668 \\
\hline & & $\mathrm{A} 1 ; \mathrm{B} 1 ; \mathrm{D} 4$ & 6903 & $\mathrm{~A} 1 ; \mathrm{C} 1 ; \mathrm{D} 4$ & 7959 & $\mathrm{~B} 1 ; \mathrm{C} 1 ; \mathrm{D} 4$ & 5016 \\
\hline
\end{tabular}

Resumo das somas de quadrados

\begin{tabular}{crrrrrrr}
\hline A e BeCeD & 45.872 .212 & A e D & 30.205 .148 & D & 21.896 .147 & ABC & 268.191 \\
A e BeC & 12.216 .795 & B e C & 7.405 .347 & AB & 820.880 & ABD & 582.330 \\
A e BeD & 40.509 .417 & B e D & 30.797 .206 & AC & 116.003 & ACD & 606.574 \\
A e C D & 32.363 .323 & C e D & 23.331 .745 & AD & 4.702 .628 & BCD & 1.098 .308 \\
BeCeD & 34.394 .255 & A & 3.606 .373 & BC & 1.063 .142 & ABCD & 774.979 \\
A e B & 9.953 .204 & B & 5.525 .950 & BD & 3.375 .110 & & \\
A e C & 4.538 .631 & C & 816.255 & CD & 619.343 & & \\
\hline
\end{tabular}

Análise do planejamento fatorial completo com 4 fatores

\begin{tabular}{|c|c|c|c|c|c|c|c|c|}
\hline \multirow{2}{*}{$\begin{array}{l}\text { Fonte } \\
\text { de Var. }\end{array}$} & \multirow{2}{*}{$\begin{array}{l}\text { Soma de } \\
\text { quadrados } \\
\text { (SQ) }\end{array}$} & \multirow{2}{*}{$\begin{array}{l}\text { Graus } \\
\text { de lib. } \\
\text { (GL) }\end{array}$} & \multirow{2}{*}{$\begin{array}{c}\text { Quad } \\
\text { médio } \\
\mathrm{QM}=\mathrm{SQ} / \mathrm{GL}\end{array}$} & \multirow{2}{*}{$F_{0}$} & \multirow{2}{*}{$F_{0,05}$} & \multirow{2}{*}{$F_{0,01}$} & \multicolumn{2}{|c|}{$\mathrm{p}$} \\
\hline & & & & & & & $F_{0}>F_{0,05}$ & $F_{0}>F_{0,01}$ \\
\hline A & 3.606 .373 & 1 & 3.606 .373 & 29,01 & 3,92 & 6,85 & Sim & Sim \\
\hline B & 5.525 .950 & 1 & 5.525 .950 & 44,45 & 3,92 & 6,85 & Sim & Sim \\
\hline C & 816.255 & 1 & 816.255 & 6,57 & 3,92 & 6,85 & Sim & Não \\
\hline$D$ & 21.896 .147 & 4 & 5.474 .037 & 44,03 & 2,45 & 3,48 & Sim & Sim \\
\hline$A B$ & 820.880 & 1 & 820.880 & 6,60 & 3,92 & 6,85 & Sim & Não \\
\hline$A C$ & 116.003 & 1 & 116.003 & 0,93 & 3,92 & 6,85 & Não & Não \\
\hline$A D$ & 4.702 .628 & 4 & 1.175 .657 & 9,46 & 2,45 & 3,48 & Sim & Sim \\
\hline$B C$ & 1.063 .142 & 1 & 1.063 .142 & 8,55 & 3,92 & 6,85 & Sim & Sim \\
\hline BD & 3.375 .110 & 4 & 843.777 & 6,79 & 2,45 & 3,48 & Sim & Sim \\
\hline$C D$ & 619.343 & 4 & 154.836 & 1,25 & 2,45 & 3,48 & Não & Não \\
\hline$A B C$ & 268.191 & 4 & 67.048 & 0,54 & 2,45 & 3,48 & Não & Não \\
\hline$A B D$ & 582.330 & 4 & 145.582 & 1,17 & 2,45 & 3,48 & Não & Não \\
\hline$A C D$ & 606.574 & 4 & 151.643 & 1,22 & 2,45 & 3,48 & Não & Não \\
\hline BCD & 1.098 .308 & 4 & 274.577 & 2,21 & 2,45 & 3,48 & Não & Não \\
\hline ERRO & 10.069 .411 & 81 & 124.314 & & & & & \\
\hline TOTAL & 55.166 .644 & 119 & 463.585 & & & & & \\
\hline
\end{tabular}

